$$
\begin{gathered}
\text { UNIVERSIDADE DE SÃO PAULO } \\
\text { MUSEU DE ARQUEOLOGIA E ETNOLOGIA } \\
\text { PROGRAMA DE PÓS-GRADUAÇÃO EM ARQUEOLOGIA }
\end{gathered}
$$

ÁGUA AOS CÂNTAROS - OS RESERVATÓRIOS DA CANTAREIRA: UM ESTUDO DE ARQUEOLOGIA INDUSTRIAL

Dalmo Dippold Vilar 


$$
\begin{gathered}
\text { UNIVERSIDADE DE SÃO PAULO } \\
\text { MUSEU DE ARQUEOLOGIA E ETNOLOGIA } \\
\text { PROGRAMA DE PÓS-GRADUAÇÃO EM ARQUEOLOGIA }
\end{gathered}
$$

\title{
ÁGUA AOS CÂNTAROS - OS RESERVATÓRIOS DA CANTAREIRA: UM ESTUDO DE ARQUEOLOGIA INDUSTRIAL
}

Dalmo Dippold Vilar

\begin{abstract}
Tese apresentada ao Programa de Doutorado em Arqueologia do Museu de Arqueologia e Etnologia da Universidade de São Paulo para obtenção do título de Doutor em Arqueologia.
\end{abstract}

Orientador: Prof ${ }^{\mathrm{a}}$ Drª Dorath Pinto Uchôa

Co-orientador: Profo ${ }^{\circ r}$ José Manuel Lopes Cordeiro

Linha de Pesquisa: 5 - Espaço e Organização Social. 
Esta Tese é dedicada ao meu filho Yuri, à Solange de Cássia e ao Marcelo, cuja compreensão e apoio, tornaram possível a realização do meu trabalho. Aos meus pais Jeorge e Eliza, minha gratidão. 


\section{AGRADECIMENTOS}

À minha orientadora, Prof ${ }^{\mathrm{a}}$ Dorath Pinto Uchôa, cujo apoio, estímulo e confiança, sempre incentivaram este trabalho.

Ao co-orientador, Prof $^{0}$ Dro José Manuel Lopes Cordeiro, da Universidade do Minho, que nos permitiu o acesso aos mais atualizados estudos de arqueologia industrial, que as bibliotecas acadêmicas possuíam.

Ao CAPES, cujo apoio institucional ao compreender a importância da pesquisa nesse ramo da ciência arqueológica, nos contemplando com uma bolsa de estudos, que nos possibilitou realizar plenamente os objetivos da pesquisa na Universidade do Minho, em Braga.

Ao prof $^{\circ} \operatorname{Dr}^{\circ}$ José Luiz de Morais, com suas sugestões e conselhos, sempre bem vindos, e sobretudo com sua amizade com a qual sempre podemos contar.

À Prof ${ }^{a}$ Drª Sílvia Maranca, pelas sugestões, que sem dúvida, contribuíram para o término desta pesquisa.

Ao Eduardo Rodrigues da Cruz, que ao longo do mestrado e do doutorado, foi incansável em conceder toda a infra-estrutura de sua organização e, acima de tudo, com sua compreensão e amizade, tão importantes para a realização serena dessas fases da minha vida.

Aos amigos do Instituto Florestal, em especial ao Fernando Déscio, Diretor do Parque Estadual da Cantareira, guarda-parques e a toda equipe, que sempre atenderam, com a maior solicitude, e deram toda ajuda para o trabalho de campo.

A Sara Cristina Alves dos Santos e Diego Romeiro pela força e ajuda tão indispensáveis para a realização de minha pesquisa. 


\section{RESUMO}

Nessa pesquisa, a metodologia da Arqueologia Industrial permitiu a análise da cultura material, da ordem urbana implantada no final do século XIX, na cidade de São Paulo, que proporcionou, uma nova configuração da vida aos seus cidadãos, com mudanças de comportamento, decorrentes da introdução de estruturas de saneamento, com a adoção de novos materiais construtivos e a conseqüente melhoria das condições de higiene e saúde, que atenderam as aspirações da elite dirigente.

É fundamental a compreensão da atuação das empresas que chamaram a si, a importante tarefa da captação e distribuição de água para sua população, a Companhia Cantareira de Águas e Esgotos, fundada em 1877, de capital privado, encampada, em 1893, pela Repartição de Águas e Esgotos, com diretrizes diversas na tentativa de solucionar o problema, que já se tornava endêmico na capital paulistana.

Nesse esforço concentrado, foram construídos na Serra da Cantareira, obras consideradas verdadeiros desafios para a engenharia da época, como reservatórios de acumulação, represas, aquedutos, e linhas adutoras, que chegavam à rede distribuidora, formando uma verdadeira artéria ao longo da cidade.

Para o resgate dessa "herança da água", hoje praticamente abandonada, foi necessária a elaboração de um inventário, onde se registrou, a localização, o estado atual, suas alterações ao longo do tempo, que resultaram na proposição de medidas de proteção e salvaguarda desse patrimônio.

Nesse contexto, é possível compreender até onde a São Paulo daquela época, que ocupava uma posição de dependência tecnológica em relação às outras metrópoles, com a importação de equipamentos hidráulicos, começa a esboçar uma reação, que incentiva a indústria paulista a fabricar esses materiais, processo esse, embrião da transformação da cidade tradicional em cidade capitalista.

Palavras Chave: Arqueologia Industrial. Cantareira. Inventário. Herança da água. Equipamentos hidráulicos. 


\begin{abstract}
This research project used Industrial Archeology to analyze the material urban culture that existed in the city of São Paulo at the end of the $19^{\text {th }}$ Century, which changed the configuration of the lives of those living in the city and changed the behavior of its citizens by implementing city sanitation systems and using new materials of construction that improved health and hygiene conditions, thus meeting the aspirations of the ruling elite.

In order to understand this process we must first understand the role of the company that took it upon itself to develop a water collection and distribution system to serve the city. Companhia Cantareira de Águas e Esgotos was a private company established in 1877. In 1893 the Water and Sewer Department took over the company and instituted numerous guidelines in order to try and solve a problem that was already endemic in the capital city of São Paulo.

As part of this focused effort, a number of structures were built in the Cantareira Mountains, such as reservoirs, aqueducts and pipelines reaching the distribution network. These were true engineering challenges at the time and the result was a network of arteries covering much of the city.

In order to recover this "water heritage", practically abandoned today, we had to first conduct an inventory that recorded the existing remnants of this structure, including its location, current state of repair, and changes over time. The end product is a list of protection measures to safeguard this heritage.

Within this context it is possible to understand when São Paulo, which had been technologically dependent on other major cities and imported all of its hydraulic equipment, started to react and encourage local industry to manufacture such goods. This process was the seed that helped transform São Paulo from a traditional to a capitalist city.
\end{abstract}

Keywords: Industrial Archeology. Cantareira. Inventory. Water Heritage. Hydraulic Equipment. 


\section{SUMÁRIO}

DEDICATÓRIA

AGRADECIMENTOS II

RESUMO III

ABSTRACT IV

1 INTRODUÇÃO

1.1 Objetos de Estudo ................................................................................. 12

1.2 Problemas $\ldots$

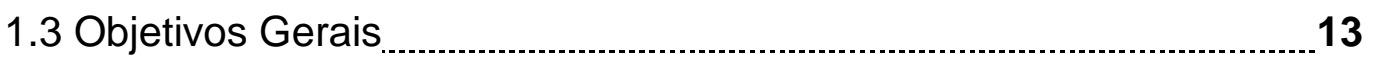

1.4 Operacionais $\ldots \ldots \ldots$

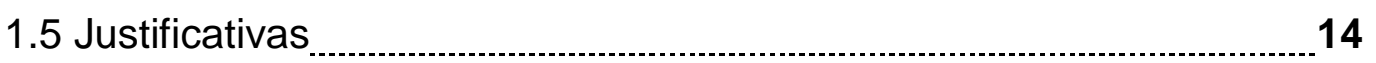

2 METODOLOGIA

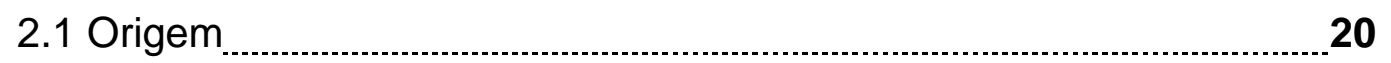

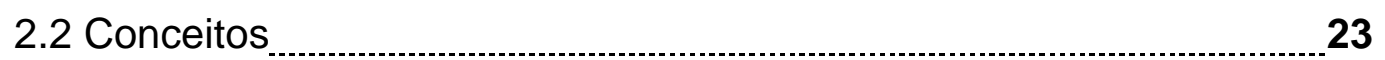

2.3 Questões de Método

3 GESTÃo DAS ÁGUAS NA SERRA DA CANTAREIRA NO SÉC. XIX 34

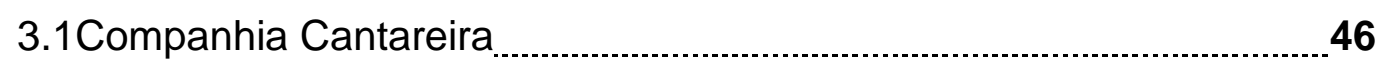

3.2 A Capital do Capital: privado ao estatal ................................................53

3.2.1 Repartição de Águas e Esgotos - ERA _....................................

3.3 Mudanças no abastecimento .................................................................. 63

3.4 A cidade se transforma

3.5 Equipamentos de Distribuição _.........................................................

3.5.1 Torneiras Públicas e Hidrômetros ................................................... 71

3.5.2 Reservatório da Liberdade ou da Avenida ................................... 74

3.5.3 Reservatório da Consolação .......................................................... 78 


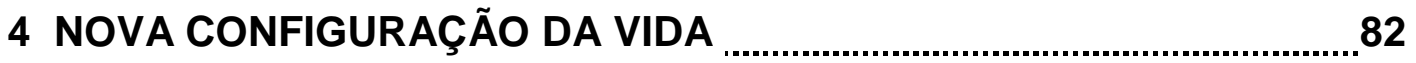

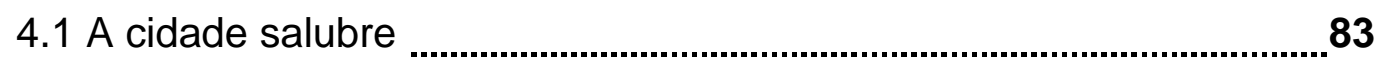

4.2 A cidade industrial .......................................................................... 93

4.3 Tramway da Cantareira .................................................................101

4.4 Captação - Obras Urbanas .....................................................................119

5 CONVERGINDO PARA A ARQUEOLOGIA DA SERRA DA

CANTAREIRA

5.1 Um Arquivo do passado

5.2. Traduzindo o modelo em inventário $\quad 126$

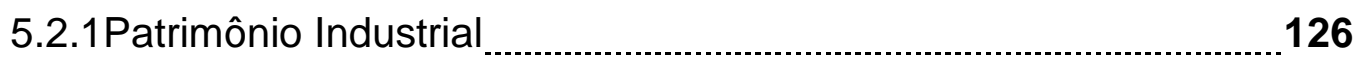

5.2.2 Haverá futuro para o passado?

5.2.3 Metodologia do inventário .................................................. 131

5.2.4 Ficha de inventário arqueológico industrial da Herança da Água

5.3 Herança da Água ..............................................................................138

5.3.1Represa da Cantareira: Antigos Reservatórios de Acumulação...139

5.3.2 Parque Estadual da Cantareira $\ldots$

5.3.2.1 Represa da Cuca ......................................................................... 145

5.3.2.2 Represa do Canivete ............................................................. 147

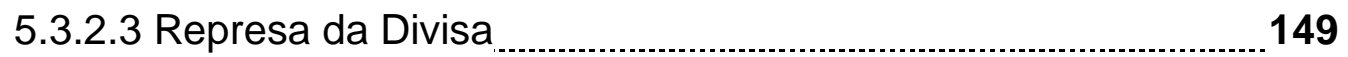

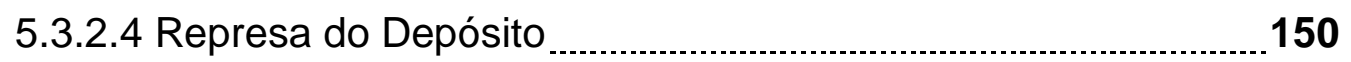

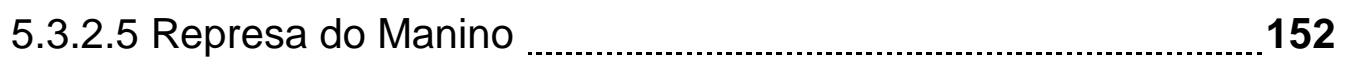

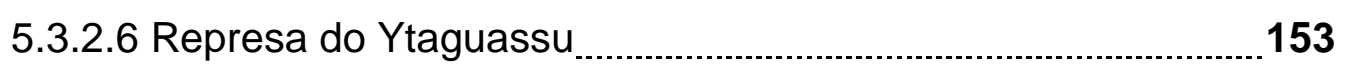

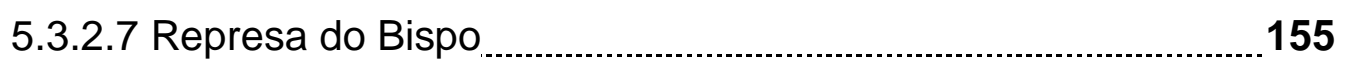

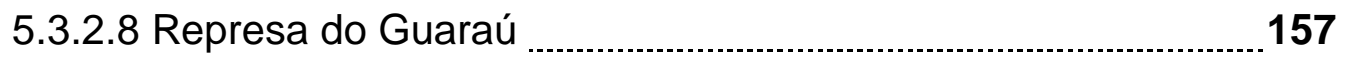

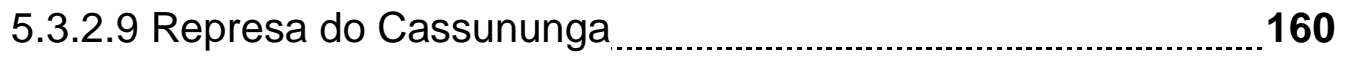

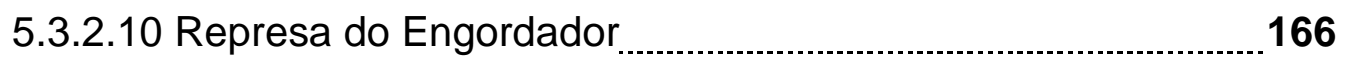

5.3.2.11 Aqueduto do Matheus ……...................................................... 170

5.4 Caixa de Junção do Guapira .................................................................173

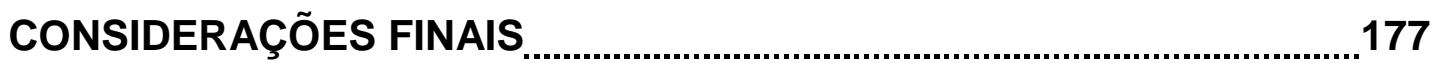


BIBLIOGRAFIA CITADA

BIBLIOGRAFIA CONSULTADA 


\section{INTRODUÇÃO}

Esta tese: "Água aos cântaros - Os Reservatórios da Cantareira: Um Estudo de Arqueologia Industrial", versará sobre o levantamento, compreensão e analise da infra-estrutura do abastecimento de água instalado na Serra da Cantareira, como barragens, represas, reservatórios de acumulação e de distribuição, aquedutos, adutoras, tubulações, introduzida por duas companhias distintas, uma de capital privado, Companhia Cantareira de Águas e Esgotos e outra estatal, a Repartição de Águas e Esgotos, conhecida como RAE . ${ }^{1}$

A metodologia para esse estudo será a da Arqueologia Industrial cujo objeto de pesquisa deve ser contextualizado de forma diacrônica e espacial, sem que um pensamento analítico fragmentário seja um redutor da realidade a ser estudada, por se tratar da análise da cultura material numa perspectiva histórica, econômica e sociológica e no que concerne à sucessão dos períodos, e no que se refere a cada um deles. Ou seja, a compreensão desta realidade no tempo e no espaço não deve ser vista como camadas sucessivas ou superpostas de fatos, de fenômenos, mas de modos de pensamento, de ação, de opções de um determinado grupo social, dentro do seu contexto.

A cidade de São Paulo até a metade do século XIX, era composta por um núcleo bem pouco expressivo - pobre e introspectivo, possuindo o município inteiro cerca de 25 mil habitantes. Entretanto, mesmo assim era possível detectar sinais de um ânimo renovado na vida da Capital, que passaria lentamente por transformações materiais.

A marcha ascendente do progresso paulista pode-se precisamente assinalar, por quatro grandes fatores que valem por outras tantas épocas memoráveis nesse período de prosperidade: a cultura do café, em larga escala, a construção da

\footnotetext{
${ }^{1}$ Dando continuidade à dissertação de mestrado, concluímos que sem um inventário não seria possível o conhecimento da herança da água, que nos foi legada e que está correndo sério risco de desaparecer. Realizado com a metodologia da Arqueologia Industrial, foi desenvolvido a partir de estudos efetuados em nosso estágio em Portugal, onde analisamos diversos tipos de inventários arqueológico-industriais, que adaptamos à realidade paulistana e aplicamos ao caso específico do fornecimento de água implantado em finais do século XIX.
} 
primeira estrada de ferro, a São Paulo Railway, a colonização ou imigração e a autonomia na República.

Conforme tese da história econômica, uma nova forma de capitalismo - agora fundamentada no capital produtivo - havia surgido nos cafezais do Oeste paulista ao término da Guerra do Paraguai, em 1870. Os reflexos dessa nova ordem econômica, contudo, demoraram a dar frutos na capital da Província. ${ }^{2}$

Ainda em 1872, o relatório do governo provincial dizia que a Capital era paupérrima, carente de equipamentos necessários à sua posição. ${ }^{3}$

As famílias ricas viviam confinadas em chácaras ou sobrados, relegando as ruas ao domínio de escravos que se concentravam nos chafarizes, assim como outros tipos populares como quitandeiros e tropeiros, que eram vistos como perigosos à nova ordem burguesa. Para afastá-los das áreas de maior circulação seria necessário empreender uma remodelação da própria cidade, vista, a partir de então, como o espaço da reforma dos costumes.

A capital incluiu-se na modernidade com o fim do escravismo e o desaparecimento de um dos primeiros fatores de diferenciação na sociedade, a posse da liberdade, o aumento do número de trabalhadores remunerados e 0 desenvolvimento de uma elite empresarial que passou a comandar a economia e a política e pretendia articular uma mudança urbana, numa concepção de cidade moderna, com novos equipamentos coletivos, como a introdução de um eficiente sistema de abastecimento de água.

\footnotetext{
${ }^{2}$ CAMPOS, Eudes. São Paulo: desenvolvimento urbano e arquitetura sob o Império.In História da Cidade de São Paulo: a Cidade na Primeira Metade do Século XX: 1890-1954.Editora Paz e Terra. São Paulo, 2004, p.214.

${ }^{3}$ Relatório Apresentado à Assembléia Legislativa Provincial de São Paulo pelo Presidente da Província o Exmo Sr. Dr José Fernandes da Costa Pereira Júnior em 2 de fevereiro de 1872, p.44: "A Capital é paupérrima de melhoramentos materiais e muito mais de melhoramentos condignos de sua categoria e importância. Falta-Ihe até edifícios para o regular serviço de administração. Funciona a Assembléia Legislativa Provincial em mesquinho recinto, fora das próprias condições que a decência exige, quanto mais das que exige a representação dos que nela desempenham o honroso mandato popular.

Não existe edifício que sirva de quartel de polícia.

Não há sequer uma biblioteca pública, nem casas apropriadas para o ensino primário. A cadeia está situada em um prédio, de proporções menos vastas do que se faz mister, velho, mal dividido e pessimamente situado. Falta à cidade regular abastecimento de água potável. Nem ao menos se tem melhorado os terrenos adjacentes ao povoado, onde as águas estagnadas infectam a atmosphera e prejudicam a salubridade pública."
} 
Um sopro de vida renovador e benéfico domina São Paulo por inteiro. A Capital transforma-se rapidamente. E como por encanto as suas planícies, ermas e sem valor em outro tempo, cobrem-se de edificações inúmeras animam-se, povoam-se e passam a valer milhões. ${ }^{4}$ (SAMPAIO, 1978)

As tradicionais construções de taipa aos poucos cedem lugar ao tijolo. Surge um outro "saber fazer", com a introdução da técnica de alvenaria, o que obrigava a importação dos novos materiais, facilitada, desde 1865, com a implantação da São Paulo Railway.

Chegavam à Capital, equipamentos hidráulicos, azulejos, e louças sanitárias da França, Inglaterra e Escócia, encanamentos da Inglaterra e da Bélgica, cimento da Alemanha e telhas de Marselha.

Estabeleciam-se em São Paulo, filiais de grandes empresas importadoras estrangeiras como a Hopkins, Causer \& Hopkins e a Zerrenner Bülow \& Com e simultaneamente as nacionais, como a Companhia Mecânica e Importadora, que também passou a fabricar maquinário para o setor cafeeiro e equipamentos para as novas obras que começavam a despontar.

Entretanto, a cidade crescia à revelia do poder público, sem controle e sem infra-estrutura, embora no âmbito da organização urbana paulistana setores considerados "progressistas" das elites insistissem em implementar um modelo de cidade eficiente. Esse fato explica porque o centro tradicional, que dispunha, a partir de 1881, de equipamentos coletivos, água, gás e coleta de esgotos, foi-se renovando, dando lugar a construções maiores, de caráter comercial, bancário e de serviços.

Como toda cidade que se desenvolve rapidamente, São Paulo apresentava diferenças flagrantes entre o seu núcleo central e seu entorno: desigualdades nas edificações, nos arruamentos, nas construções realizadas sem planejamento, e na ausência de infra-estrutura de saneamento básico, como é o caso do abastecimento de água, aliado a um crescimento demográfico impressionante de aproximadamente 64.934 habitantes em 1890 para 239.434 em $1900 .^{5}$

\footnotetext{
${ }^{4}$ SAMPAIO, Teodoro. São Paulo no Século XIX e outros ciclos históricos. Ed. Vozes. Petrópolis, Rio de Janeiro, 1978, p.99.

${ }^{5}$ MATOS, Odilon Nogueira. São Paulo no século XIX in A cidade de São Paulo - Estudos de Geografia urbana, Cia Editora Nacional, São Paulo, [19--], p.82.
} 
Os graves problemas enfrentados por uma São Paulo no final do século XIX, só se acentuariam ao longo do tempo. Cabia, portanto, aos protagonistas da recém implantada República, equacioná-los e resolvê-los, tudo isso acontecendo, logicamente, dentro da perspectiva proporcionada pelos estreitos limites de sua visão de classe.

Quanto aos serviços de utilidade pública, em especial o saneamento básico, até 1877, com a fundação de uma empresa particular, a Companhia Cantareira de Águas e Esgotos, poucas providências tinham sido tomadas pelo governo provincial, com relação à distribuição de águas e tratamento de esgotos. Até então, esse sistema consistia na construção de chafarizes e colocação de torneiras públicas onde os escravos e os aguadeiros buscavam água para as residências, sendo inexistente qualquer tipo de coleta pública de esgotos.

O fornecimento de água é o que está mais ligado às condições de vida da população, que dele não pode prescindir, para suas primordiais necessidades de existência.

Desde 1877, a água que abastecia a paulicéia, provinha dos mananciais da Serra da Cantareira, porém, mesmo após a encampação da citada Companhia e as novas obras de ampliação implementadas em 1894, pela sua sucessora a Repartição de Águas e Esgotos, a São Paulo daquela época, infelizmente, não tinha um serviço de água adequado à curva de crescimento da cidade e de sua população.

Em se tratando desta pesquisa, uma das questões que se coloca é como recuperar o processo de introdução e difusão da gestão da água na Serra da Cantareira no final do século XIX, não só retratando como isso ocorreu, mas buscando, sobretudo, compreender a sua dinâmica, determinando os agentes e fatores mais importantes desse processo, assim como a forma e o porquê de sua ineficiente atuação.

Nesta perspectiva serão contemplados os desdobramentos que uma obra de tal porte implica em tecnologias, que deixaram seus vestígios materiais muitas vezes visíveis, inseridos na paisagem que merecem ser resgatados e preservados.

O poder público, na esteira das transformações econômicas ocorridas no final do século $\mathrm{XIX}$, aos poucos foi racionalizando os usos sociais das modernas infraestruturas e da própria esfera do privado, obrigando a mudanças de hábitos de 
higiene através da promulgação do Código Sanitário de $1894^{6}$, que entre outras providências, alterava a técnica construtiva das habitações com a introdução de novos materiais que pudessem atender aos ditames dos preceitos higienistas de então.

Pretendeu-se identificar, as empresas nacionais e estrangeiras que tiveram participação decisiva nessa nova configuração da vida urbana, fornecendo materiais para a implantação do serviço de saneamento, quais foram as obras construídas para viabilizá-lo, e que mudanças geraram no cotidiano da população paulistana.

\subsection{Objetos de Estudo}

As obras de infra-estrutura do abastecimento de água implantadas na Serra da Cantareira no século XIX, como reservatórios de acumulação e de distribuição, represas, aquedutos, sistemas de adução e as tubulações, que formaram uma verdadeira artéria ao longo da cidade, naquele que foi o século de ouro do encanamento, gerando mudanças de hábitos de higiene, e o desenvolvimento de empresas ligadas às novas técnicas de saneamento, então empregadas.

As alterações que essas construções sofreram ao longo dos últimos cem anos.

O resgate da memória dos sistemas tecnológicos desenvolvidos no processo de captação e adução de água, ou seja, da conquista de um equipamento coletivo essencial ao bem estar da comunidade.

Elaborar, com a metodologia da Arqueologia Industrial, um modelo de inventário dessas obras como instrumento de análise com a finalidade de localizar, identificar e interpretar sua função inicial e atual, registrando e propondo medidas de proteção, salvaguarda e reabilitação.

\footnotetext{
${ }^{6}$ São Paulo, Leis e Decretos. Decreto no 233 de 2 de Março de 1894. O Presidente do Estado, para a execução do artigo 3ำ da Lei oㅡ 240 de 4 de Setembro de 1893, estabelece o Código Sanitário.
} 


\subsection{Problemas}

A gestão da água na Serra da Cantareira, coordenada pela Companhia Cantareira de Águas e Esgotos e sua sucessora a Repartição de Águas e Esgotos, possibilitou que a área fosse preservada, dando origem a um dos maiores parques urbanos do mundo, com 7.900 ha.

No contexto capitalista do século XIX, São Paulo ocupava uma posição periférica com grande dependência tecnológica, e a implantação das obras de abastecimento na Serra da Cantareira, se por um lado, implicaram na importação de equipamento hidráulico, e de novos materiais, por outro, funcionaram como vetores de pressão para novos empreendimentos, na fabricação e aperfeiçoamento destes produtos.

Sendo a R.A.E. uma repartição do Estado, as obras exigiam autorização de outros órgãos ligados à burocracia estatal, o que possibilita através de uma Arqueologia da fonte secundária, encontrar catálogos, material de propaganda e certificados de garantia dos fabricantes, literatura geralmente negligenciada e pouco preservada pelas empresas e bibliotecas, sendo rara fonte de consulta, fundamental para a Arqueologia Industrial, permitindo muitas vezes, o resgate do processo de fabricação desses produtos. ${ }^{7}$

\subsection{Objetivos Gerais}

Com o estudo desses vestígios materiais e sua contextualização, com a metodologia da arqueologia industrial, pretende-se levantar informações que possibilitarão a compreensão das mudanças nas habitações, nos hábitos e costumes da população paulistana com a introdução da água encanada no cotidiano, uma vez que segundo Pinard, um dos objetivos da Arqueologia Industrial é:

\footnotetext{
${ }^{7}$ Este tipo de fonte faz parte do Patrimônio Industrial e segundo PANNEL, J.P.M. The Techniques of Industrial Archaeology, editado por J. Kenneth Major, Great Britain, 1974, p. 119,120, é importante a busca deste tipo de material uma vez que os fabricantes europeus tiveram parte de seus arquivos destruídos durante as duas grandes guerras mundiais.

O autor mostra a dificuldade em encontrar catálogos e folhetos de propaganda do século XIX, nas bibliotecas européias, porém, sendo o capitalismo um modo de produção em escala mundial, países dependentes de produtos importados podem involuntariamente ter preservado esse patrimônio.
} 
(...) tentar encontrar as circunstâncias materiais e técnicas que estiveram na origem da produção de um determinado produto, da montagem de uma fábrica ou de um equipamento coletivo, como é o caso do abastecimento água, que tenha marcado a vida dos seus contemporâneos, e em seguida procurar as conseqüências que estes acontecimentos tiveram sobre os aspectos que rodeiam uma população ou um grupo social". 8 (MADEIRA, 1989)

O resultado dessa pesquisa, serviu de base a um modelo de inventário elaborado com a metodologia da Arqueologia Industrial, que funcionará como um instrumento de identificação e gestão patrimonial, de divulgação, conhecimento e intervenção, para o manejo e a administração do Parque Estadual da Cantareira, criado pelo Decreto $41.626 / 1963 .^{9}$

\subsection{Operacionais}

Com o método arqueológico "in situ", e o complexo das operações de localização, identificação, descrição, análise, interpretação, leitura crítica dos dados fornecidos e sua sistematização, foi feita a base do inventário arqueológico industrial.

Consultando os relatórios da Cia. Cantareira e da Repartição de Águas e Esgotos, a bibliografia especializada, os documentos iconográficos e tendo como suporte os métodos históricos, contextualizou-se a gestão da água no século XIX, na cidade São Paulo e suas repercussões na moradia e no próprio comportamento da população.

\subsection{Justificativas}

A década de 1870 apresentou-se como um marco no grande progresso pelo qual passou a cidade de São Paulo. ${ }^{10}$ Foram introduzidos nas edificações paulistanas os avanços tecnológicos que possibilitaram o conforto da água corrente,

\footnotetext{
${ }^{8}$ MADEIRA, A. Apud Uma vila industrializada: tortozendo, centro produtor de lanifícios, na área da Serra da Estrela, in I Encontro Nacional sobre o Património Industrial, ed Coimbra, Portugal, 1989 p.397.

${ }^{9}$ São Paulo, Leis e Decretos. Decreto № 41.626 de 30 de janeiro de 1963. Regulamenta a execução da Lei no 6884 de 29 de agosto de 1961, que dispõe sobre os Parques, Florestas e Monumentos naturais.

${ }^{10}$ Será tratado com maiores detalhes, no Capítulo III.
} 
mudando a própria dinâmica de funcionamento das casas e dos prédios públicos. A partir desse momento, ou adaptavam-se os cômodos em função dos encanamentos, como era o caso do banheiro, ou construíam-se outros para usufruir desse bemestar material.

A tecnologia da época apresentava diferentes invenções, principalmente inglesas, como foi o caso da torneira de rosca e outros equipamentos industriais importados e introduzidos na infra-estrutura do saneamento da cidade.

Justifica-se este trabalho pelo resgate e salvaguarda que se pretende fazer desta cultura material praticamente negligenciada pelos órgãos de preservação do patrimônio cultural, uma vez que as análises detalhadas das mudanças tecnológicas no abastecimento de água, foram raramente registradas e a sua importância muitas vezes passou despercebida.

Justifica-se ainda, pela preocupação em preservar aqueles vestígios que ainda não foram destruídos e que podem ser inventariados e posteriormente tombados sob pena de serem irremediavelmente perdidos. Infelizmente, a apatia e o silêncio muitas vezes se deparam na questão da preservação das obras públicas vistas como utilitárias sem o conteúdo de imponência artística que justifique seu tombamento.

De acordo com o item 10 da Carta de Campinas:

"Todas as instalações e estruturas das edificações utilitárias protegidas devem ser respeitadas, incluindo-se pisos, calçadas, bases de máquinas, paredes, tabiques, escadarias, dutos e aquedutos, (grifo nosso), trilhos, canaletas e outras, ainda que a maquinaria e equipamentos tenham desaparecido. ${ }^{111}$

Há, portanto, uma necessidade urgente de se registrar essas obras, através da pesquisa e do inventário arqueológico, uma vez que correm o risco de serem deixadas no esquecimento, sendo passíveis de destruição.

\footnotetext{
11 DECLARAÇÃO DO GEHT, em defesa das construções e instalações utilitárias ("Carta de Campinas") - UNICAMP, 1998. Os membros do Grupo de Estudos de História da Técnica-GEHT, (ligado ao Centro de Memória-CMU, da Universidade Estadual de Campinas-UNICAMP, Estado de São Paulo), reunidos em 19 de junho de 1997, 24 de julho, 18 de setembro, 13 de novembro e 11 de dezembro do mesmo ano, discutiram sobre a conservação dos bens culturais designados por "construções e instalações utilitárias", ligadas aos ofícios, às profissões, e às indústrias. Em 29 de janeiro de 1998 na última reunião do grupo resolveram elaborar uma Declaração do GEHT em defesa das construções e instalações utilitárias, que passou a ser conhecida como a "Carta de Campinas". Com esta Declaração, os membros do grupo de estudo da história da técnica, esperavam sensibilizar os profissionais ligados à conservação e pesquisa de bens culturais com relação à necessidade de se preservar a memória da produção industrial e seus testemunhos materiais.
} 
Iniciar um trabalho deste tipo no Brasil, é, antes de tudo, mostrar a abrangência e a importância da ciência arqueológica inclusive na recuperação de passado próximo, que apesar da pouca distância cronológica, já está desaparecendo na Memória Nacional... "12 (LOTUFO, [19--])

${ }^{12}$ LOTUFO, C. L. Os Primórdios da industrialização no Município de Engenheiro Frontin, RJ, Munda, no 22, Coimbra, Portugal, [19--], p. 107. 


\section{METODOLOGIA ${ }^{13}$}

As sociedades modernas usufruem benefícios e um progresso material inegáveis, ambos resultantes da Revolução Industrial que, a partir de 1750, foi a responsável por um encadeamento de profundas mudanças na estrutura sócioeconômica mundial, em praticamente todas as áreas da vida social de quase todos os indivíduos, acarretadas pelo desenvolvimento da tecnologia.

O progresso industrial transformou, sem dúvida, o modus vivendi e o padrão de vida do homem ao longo dos últimos dois séculos. A enorme quantidade de bens produzidos alterou radicalmente o ambiente físico dos lares, a natureza das instituições políticas, o lazer e a recreação, o vestuário e, até mesmo, as normas de comportamento.

Embora constituindo apenas uma parte da complexa sociedade contemporânea, a indústria é, por certo, seu sistema de produção mais importante, assim como em outras épocas predominaram as corporações de ofício ou a escravatura. Por tudo isso os cientistas sociais chamam as sociedades modernas de "industriais".

Um dos traços mais marcantes do nosso sistema industrial, que contrasta essencialmente com outras estruturas de produção, é a invenção constante de novas máquinas, novos processos físicos ou químicos e novos princípios organizacionais.

Os impulsos desse extraordinário desenvolvimento surgem da busca empresarial de lucro e das conquistas tecnológicas: uma invenção conduz a uma outra, um novo princípio de organização desencadeia um outro e a introdução de um moderno processo químico pode sugerir um novo produto.

A procura constante por uma melhoria técnica não é recente, pois se perde nos tempos imemoriais, no cotidiano da humanidade, intervindo em sua vida cultural, social e econômica. Porém foi somente a partir da chamada Revolução Industrial que a técnica adquiriu a tonalidade mais forte de um dos agentes centrais do

\footnotetext{
${ }^{13}$ Esta metodologia foi desenvolvida em conjunto com Filomena Pugliese Fonseca, com base em nossos estudos de Arqueologia Industrial, na Universidade do Minho, em Portugal, sob a coorientação do Professor Dr José Manuel Lopes Cordeiro, tendo sido também aplicada em sua tese: As águas do passado e os reservatórios do Guaraú, Engordador e Cabuçu:

Um estudo de arqueologia industrial.
} 
processo sócio-econômico moderno. Nesse movimento de âmbito internacional, ocorrido principalmente nas últimas décadas do século XIX e XX - este considerado - século da chamada Terceira Revolução Industrial - cada vez mais os conhecimentos científicos passaram a ser aplicados ao sistema produtivo, bem como foram estabelecidas novas interações entre suas áreas. Associada à ciência, na forma de tecnologia, a Revolução transformou-se em um trunfo decisivo da competição industrial, da disseminação de novos produtos e de novas formas de comportamento.

As pequenas oficinas dos artesãos foram sendo substituídas pelas fábricas, as ferramentas simples, trocadas pelos novos equipamentos que haviam surgido. As tradicionais fontes de energia (água, vento e força muscular) foram superadas pelas máquinas a vapor e pela eletricidade. Houve um grande desenvolvimento dos meios de transporte e comunicação e um considerável acréscimo do controle capitalista sobre quase todos os ramos da indústria. A velha Europa agrária foi se tornando uma região com cidades populosas e industrializadas e esse modelo, cujas transformações implicaram uma nova organização social, expandiu-se por inúmeras regiões do mundo.

Portanto, nos últimos duzentos anos, assistimos a um avanço tecnológico sem precedentes na história da humanidade. Dessa forma, os vestígios materiais das fábricas, maquinários, sistemas de transporte e de abastecimento de água, entre outros, foram relegados na avançada marcha do progresso, havendo a necessidade de preservar-se esse passado onde seja possível, tornando-se fundamental que se estude e pesquise essa herança industrial para que futuras gerações compreendam de que forma chegou até nós e quais são seus similares.

Conforme CORDEIRO, 1994, as diferentes fases pelas quais passou o processo de industrialização proporcionaram à humanidade um importante legado patrimonial, que se materializa numa enorme diversidade de vestígios. ${ }^{14}$

Por outro lado, a rápida evolução tecnológica dos últimos decênios gera uma grande transformação industrial em um processo que, segundo Schumpeter, revoluciona incessantemente a estrutura econômica a partir de dentro, destruindo de

\footnotetext{
${ }^{14}$ CORDEIRO, J.M.L. Arqueologia Industrial. Uma vertente fundamental da Arqueologia Urbana. In Encontro de Arqueologia Urbana, Braga, 1994, p.170.
} 
maneira contínua o antigo, criando elementos novos, "a destruição criadora" ${ }^{15}$, que, aliada aos dois conflitos mundiais e a uma atitude cultural de indiferença, contribuiu para uma acentuada dilapidação do patrimônio industrial, que possui um valor social como parte do registro de vidas de homens e mulheres e, como tal, proporciona um importante sentimento de identidade. Ao conteúdo universal dessa evidência, agregam-se também valores tecnológicos e científicos na história da produção, da engenharia, da construção e aqueles de caráter estético, determinados pela qualidade de sua arquitetura, desenho ou planificação.

Antigas instalações industriais, minas desativadas, moinhos, construções, canais para navegação, infra-estruturas de abastecimento de água, ferrovias, barcos e outros atualmente despertam interesse cultural e turístico, tornando-se profundamente significativos para um grande número de pessoas que os consideram como parte integrante de seu patrimônio cultural.

Ao longo dos últimos anos, em numerosos países industrializados, aumenta o interesse pela preservação dos vestígios de seu passado industrial. Dessa conscientização nasce igualmente uma reflexão sobre sua natureza, sobre quais desses vestígios devem ser conservados, sobre a importância de seus estudos e a sensibilização do público para sua preservação.

A salvaguarda das primeiras máquinas, a restauração e a reabilitação dos edifícios que as abrigam, o inventário da documentação social, econômica e técnica pertencem ao patrimônio coletivo de cada país, uma vez que ilustram uma grande parte de sua história nos últimos séculos.

As destruições muito numerosas e cotidianas dos produtos industriais, sítios, edifícios e demais estruturas, objetos, máquinas, manuais, catálogos, arquivos públicos e empresariais fazem com que desapareçam muito rapidamente os vestígios do passado industrial de um país.

A valorização dessa herança industrial pode ser traduzida de diferentes maneiras: pesquisas, levantamento e interpretação dos documentos arquivados, conservação, reciclagem e criação de museus, ecomuseus, museus de Ciência e Tecnologia e de Arqueologia Industrial.

A conservação do aludido patrimônio representa uma escolha da sociedade, cujo efeito repercutirá sobre as gerações vindouras, uma vez que implica uma

\footnotetext{
${ }^{15}$ SCHUMPETER, J.A. Capitalismo, Socialismo e Democracia, Ed. Fundo de Cultura, Rio de Janeiro, 1961, p.106.
} 
conscientização de indivíduos ou de grupos sociais que vivem as contradições dos avanços tecnológicos do século XXI, o que dependerá de muitos fatores como, por exemplo, da importância histórica, arqueológica e arquitetural do monumento ou sítio, do seu estado de conservação, do potencial de sua manutenção e reuso, bem como da disponibilidade de fundos e do impacto econômico e social de sua valorização.

Segundo BUCHANAN, 1985, a ciência que tem um campo de estudo concernente a pesquisa, exame, levantamento, registro e, em certos casos, preservação dos monumentos industriais é a Arqueologia Industrial que visa, entre outros objetivos, evidenciar a importância desse patrimônio dentro do contexto da história social e da tecnologia. ${ }^{16}$

\subsection{Origem}

O termo Arqueologia Industrial foi empregado pela primeira vez em 1876, na França, pelo Barão de Verneilh, para propor o estudo arqueológico das forjas do Perigord e de Limoges, dos séculos XV ao XVIII, sem qualquer ligação necessária com a Revolução Industrial Inglesa.

Oliveira Martins, em 1884, quando diretor do Museu Industrial e Comercial da cidade do Porto, defendeu que nos Museus Industriais se expusessem objetos arqueológicos industriais, porém VITERBO, 1896, propõe a criação da Arqueologia Industrial para o estudo do passado fabril de Portugal, na tentativa de salvaguardar seu patrimônio quando enfatizava: "antes que tudo se perca irremediavelmente, salvemos pela descrição e pela estampa o que ainda resta, dilacerado e partido, dos antigos documentos da laboriosidade portuguesa". ${ }^{17}$

Entretanto as pesquisas nesse campo científico não tiveram prosseguimento. Após a Segunda Guerra Mundial, com a reconstrução e a substituição de indústrias consideradas obsoletas, houve uma conscientização de que edifícios, maquinário e arquivos deveriam ser preservados como testemunhos

\footnotetext{
${ }^{16}$ BuChANAN, A. The Definition of Industrial Archaeology, In "L'étude et la Mise en Valeur du Patrimoine Industriel. 4a Confèrence internationale.Lyon-Grenoble, Septembre, 1981. Ed.du Centre National de La Recherche Scientifique, Paris, 1985, p.104.

${ }^{17}$ VITERBO, Souza Francisco. "Arqueologia Industrial Portuguesa; os moinhos". In O Arqueólogo Português, Vol II, no 8 e 9, 1896, p. 68 a 72.
} 
da era industrial, inclusive aquelas unidades fabris ainda em fase de implantação nos primeiros anos do século XX, desaparecidas com os conflitos bélicos.

Somente na década de 1950, a expressão Industrial Archaeology foi empregada por Donald Dudley, professor da Universidade de Birmingham, e publicada pela primeira vez por Michael Rix, em 1955.

Este, em seu artigo The Amateur Historian, relaciona como campo de estudo, até aquele momento não explorado, uma série de monumentos pertencentes ao século XVIII e ao começo do século XIX: fábricas, máquinas a vapor, locomotivas, os primeiros edifícios com estrutura de metal, aquedutos e pontes de ferro fundido, os pioneiros empreendimentos em ferrovias, canais e eclusas. Faz então um alerta, para que sejam preservados em razão de estarem muitos deles ameaçados de destruição, conservando-se, se possível, a documentação ainda existente. ${ }^{18}$

A constituição da Arqueologia Industrial como ciência dos vestígios deixados pelas sociedades industriais surgiu paralelamente às primeiras ações e medidas de proteção e preservação do patrimônio industrial, após a destruição do Palácio de Cristal do Porto, da gare de Euston Station, em 1962, dos pavilhões Halles Centrales de Baltard, em Paris, e a destruição parcial da antiga escola industrial Marquês de Pombal, em Alcântara, Portugal.

Ainda nessa década, introduzida por Angus Buchanan, essa nova disciplina passa a fazer parte da grade curricular da Universidade de Bath, concomitantemente com as primeiras sociedades conservacionistas, preocupadas com o patrimônio da indústria de mineração.

Esse movimento teve conotações diversas em vários países: na Inglaterra, ocorre um forte associativismo, com a Newcomen Society, centrada na história da engenharia e da tecnologia, que lança, em 1964, o Journal of Industrial Archaeology; e, em 1976, a Association for Industrial Archaeology, fundada três anos antes, inicia a publicação da Industrial Archaeology Review.

Em 1963, o poder público britânico, através do Conselho Britânico de Arqueologia e do Ministério de Obras Públicas, inicia um levantamento dos monumentos industriais, estabelecendo o NRIM, National Record of Industrial

\footnotetext{
${ }^{18}$ HUDSON, Kenneth. "Industrial Archaeology, an Introduction". $2^{2}$ ed. John Baker Publishers, London, 1966, p.11.
} 
Monuments, que faz parte, desde 1981, da Real Comissão de Monumentos Históricos da Inglaterra.

CORDEIRO, 1994, ${ }^{19}$ anotou que os movimentos de defesa do patrimônio em Portugal tiveram início no final da década de 1970. Em 1980, nesse país, surgiram vários projetos de investigação na área da manufatura do vidro e, em 1985, realizouse a Exposição de Arqueologia Industrial da Central do Tejo, marcante para a divulgação dos trabalhos desse novo campo científico.

Na França, o movimento teve início na década de 1960, quando os poderes públicos e a imprensa começaram a se preocupar com a preservação das ferrovias turísticas como a de Meyzieu, perto de Lyon. Foi o primeiro museu ferroviário da França acolhendo materiais antigos, salvaguardando-os e preservando-os, em funcionamento.

Em 1977, a Universidade Sorbonne, em Paris, criou um Centro de Arqueologia do Mundo Moderno, sob a direção de Philippe Bruneau, divulgando os trabalhos em andamento na área, através de uma revista anual. ${ }^{20}$

O museólogo Georges-Henri-Rivière contribuiu, com planos teóricos e práticos, para a criação dos primeiros ecomuseus, que promovem o encontro entre as ciências do homem e as da natureza, procurando popularizar a ciência e a tecnologia, em prol do desenvolvimento local. Ao lado deles, a fundação de museus específicos, como o "Museu do Ferro", criado em Jarville, perto de Nancy, em 1966, foi mais um dos esforços efetuados para apresentar os vestígios industriais ao público.

A inserção da Arqueologia Industrial na Alemanha deu-se em um contexto universitário no fim dos anos sessenta, passando a fazer parte dos currículos dos cursos de tecnologia, cuja preocupação com os monumentos, parte visível da herança industrial, permite reconstituir a atividade das forças produtivas na sociedade, bem como as condições sociais nas quais essas forças nasceram.

Em 1977, na Itália, nasceu o debate sobre Arqueologia Industrial, a denominação da disciplina, seu significado e a delimitação de seu campo de

\footnotetext{
${ }^{19} \mathrm{CORDEIRO}$,José Manoel Lopes. Arqueologia Industrial, uma vertente fundamental da Arqueologia Urbana. Encontro de Arqueologia Urbana, Braga, 1994, p.169.

${ }^{20}$ BARRAL I ALTET, Xavier. L'Archéologie de I'age industriel, Archéologie et Industrie. In: Les Dossiers de L'Archéologie. Dijon: Faton, 1986.
} 
pesquisa, culminado, um ano depois, com a publicação de Introduzione alla archeologia industriale, por Franco Borsi. ${ }^{21}$

Nesse mesmo ano, a revista Abitare $^{22}$, em seu artigo Archeologia Industriale: Che Cos'è, um caso vivo da discutere: il Villaggio Leumann marca o início dos debates sobre a segregação espacial dos trabalhadores nas vilas operárias, sob a ótica dessa nova disciplina.

Nos Estados Unidos, a Sociedade de Arqueologia Industrial surgiu em 1971, iniciando em 1975 a publicação do Journal of the Society for Industrial Archeology.

Ao longo dos anos, o campo de pesquisa da Arqueologia Industrial tornou-se mais abrangente estudando os vestígios materiais e imateriais do período da Revolução Industrial, embora existam grandes diferenças entre formas e períodos de implantação nos vários países.

Segundo BUCHANAN, 1972, para efeitos de periodização, a data de 1776 pode ser considerada como um marco da Revolução Industrial, ano de três grandes acontecimentos: a construção da ponte de ferro de Ironbridge ${ }^{23}$ da publicação de A Riqueza da Nações, de Adam Smith, e da Independência das Colônias Inglesas na América do Norte. ${ }^{24}$

\subsection{Conceitos}

Em sentido amplo, "Arqueologia Industrial é o estudo das causas, características e conseqüências da industrialização, baseado na identificação, registro, preservação e interpretação dos vestígios da indústria em seu contexto cultural e histórico". 25 (ORSER, 2002)

\footnotetext{
${ }^{21}$ BARBIERI, Franco. "Archologia industriale e storia dell'arte". In Archeologia Industriale. Indagini sul território in Lombardia e Veneto. Edizioni Unicolpli., Milano, 1989, p.7.

${ }^{22}$ ABITARE, no 158, Milano, Ottobre 1977, p.76 a 95.

${ }^{23}$ Condado de Shropshire, centro da Inglaterra, é o lugar onde a Revolução Industrial teve origem, com Abraham Darby, que em 1755 substituiu a utilização do carvão vegetal pelo coque, derivado do carvão mineral, na fundição de Coalbrookdale. Em Ironbridge, também foi construída a primeira ponte de ferro fundido do mundo, revolucionando o sistema construtivo empregado até então, com alvenaria ou madeira.

${ }^{24} \mathrm{KÜHL}$, Beatriz Mugayar. Arquitetura do Ferro e Arquitetura Ferroviária em São Paulo: Reflexões sobre a sua preservação. São Paulo: Ateliê FAPESP, Secretaria da Cultura, São Paulo, 1998, p.225.

${ }^{25}$ ORSER JR, Charles. Encyclopedia of historical archaeology, Ed.Charles, New York, Routledge, 2002, p.286.
} 
Ramo especializado da Arqueologia, seu estudo procura abarcar as evidências tangíveis do desenvolvimento social, econômico e tecnológico do período que se inicia com a Revolução Industrial, para transcender em importância, o papel que desempenhou na sociedade, como testemunho histórico de um sistema que transformou a humanidade.

Para PALMER, 1990, o arqueólogo industrial pode considerar-se como o arqueólogo da sociedade industrial, não estudando seqüências de mudanças ao longo de um extenso período de tempo, como geralmente é realizado nas arqueologias de períodos mais remotos, o que é, no entanto, compensado pelo ritmo de desenvolvimento tecnológico extraordinariamente rápido desses dois últimos séculos, em comparação com o ocorrido em qualquer outro período do passado. ${ }^{26}$

O objeto das pesquisas da Arqueologia Industrial situa-se, cronologicamente, a partir da segunda metade do século XVIII; conseqüentemente, trabalha com um espaço de tempo mais exíguo, no qual existe, porém, uma enorme gama de documentos escritos e iconográficos, que são válidos, mas complementares, nunca substituindo as evidências arqueológicas na interpretação da cultura material das sociedades que passaram pelo processo da industrialização.

HUDSON, 1998, um dos importantes teóricos da Arqueologia Industrial, apresenta uma definição concisa do que seria a disciplina: a descoberta, registro e estudo dos resíduos físicos da indústria e meios de comunicação do passado. ${ }^{27}$

\begin{abstract}
A arqueologia industrial deve investigar todos os vestígios ou remanescentes do passado, que o aproximem ao máximo das atividades e das técnicas desenvolvidas pelo e para o homem, utilizando vários métodos para situá-las no tempo e no espaço. ${ }^{28}$ (PRADAYROL, 1985)
\end{abstract}

\footnotetext{
${ }^{26}$ PALMER, Marilyn. Industrial archaeology: a thematic or a period discipline? In Antiquity, Cambridge, 64 (243), 1990, p.281.

${ }^{27}$ HUDSON Keneth, Apud KÜHL, B.N. Arquitetura do ferro e Arquitetura Ferroviária em São Paulo: Reflexões sobre a sua preservação. São Paulo, Ed. Ateliê, 1998.

${ }^{28}$ PRADAYROL, Jacques. Les Chemins de Fer Touristiques Pionniers de L'Árchéologie Industrielle en France. In 4a Cenférence Internationale de Lyon-Grenoble, Éditions du Centre National de La Recherche Scientifique, Paris, 1985, p.79.

${ }^{29}$ PINARD, Jacques. L'archéologie industrielle. Presses Universitaires de France, Paris, 1985, p.6.
} 
Portanto, não busca apenas retratar a história econômica e social de toda uma região ou de um país, a partir de documentos materiais descobertos através de pesquisas de exploração em superfície ou de escavações, mas, reencontrar as circunstâncias materiais e técnicas que estão na origem de uma fábrica, na montagem de uma máquina ou na construção de um estabelecimento, dos equipamentos coletivos, que marcaram a vida de seus contemporâneos e, em seguida, pesquisar as conseqüências que esses "acontecimentos" tiveram sobre todos os dados do ambiente de uma população ou grupo social. ${ }^{29}$

O abastecimento de água e toda sua estrutura como, por exemplo, açudes, comportas, barragens, aquedutos, adutoras, tubulações estão na categoria dos chamados equipamentos coletivos.

Segundo Mendes, dessa vasta área também fazem parte o abastecimento e distribuição de energia, estruturas relativas ao fornecimento de gêneros alimentícios como mercados, armazéns e entrepostos; estabelecimentos das áreas de ensino e da saúde e estruturas de lazer, como cinemas, teatros, parques de diversão, estádios e outros. ${ }^{30}$

Mais que uma história das ciências e das técnicas, a Arqueologia Industrial procura reconstituir, a partir de elementos concretos, o espaço material e humano que envolve uma sociedade, seu patrimônio industrial, que merece ser estudado e preservado.

\subsection{Questões de método}

O objetivo da Arqueologia Industrial é a aproximação, em uma dimensão mais concreta, dos estudos de história econômica, social, das ciências e da tecnologia, baseia-se, sobretudo, nos artefatos, documentos de arquivos escritos e iconográficos e, da mesma forma, nos relevos topográficos e arquiteturais. Fundamentada sobre a multidisciplinaridade, utiliza as ciências do homem, como a arquitetura e a engenharia, incluindo expressamente todos os documentos e testemunhos pertencentes a essas disciplinas. ${ }^{31}$ (TROTTIER, 1987)

\footnotetext{
${ }^{30}$ MENDES, José M. Amado. Património Industrial: um bem da comunidade ao alcance da escola. In Revista Munda ํㅜ 16, EditoraGAAC, Coimbra, 1988.

${ }^{31}$ TROTTIER, Louise. Lê patrimoine Industriel au Québec. Éd. Commission des biens cullturels du Québec, Canadá, 1987, p.15.
} 
A Arqueologia Industrial, no estudo da cultura material, proporciona uma visão mais abrangente dos aspectos da produção, reprodução, distribuição e consumo de bens do sistema capitalista e as condições em que foram realizadas; portanto, com sua metodologia, analisa e interpreta, a partir dessas evidências materiais, as mudanças sociais, econômicas e culturais decorrentes do crescimento da organização capitalista na indústria.

Essa evolução, aumenta o número de temáticas a serem investigadas, ampliam-se as questões, fazem-se novas interrogações no campo da cultura material, definida por GLASSIE, 1998, "como aqueles segmentos da aprendizagem humana que proporcionam ao indivíduo planos, métodos e razões para produzir coisas que se podem ver e tocar"32, e que. vem sendo progressivamente investigados e valorizados pela pesquisa, em vários domínios.

Para BRAUDEL, 1998, nossa sociedade pode ser definida, como a sociedade da "civilização material." 33

"Escusado será dizer que no estudo destas, como de outras temáticas, a arqueologia industrial pode prestar um excelente auxílio, especialmente no que toca à utilização de fontes materiais, com as quais está inteiramente relacionada". ${ }^{34}$

Através de técnicas arqueológicas de resgate e documentação da cultura material, é que se pode pensar em salvaguardar e valorizar a herança industrial.

Para JORGE, 1987, a unidade informativa básica da Arqueologia advirá do estudo de áreas pesquisadas segundo seus dois vetores principais: diacrônico e espacial. ${ }^{35}$

Seu objeto de estudo deve ser contextualizado no campo da História Social e da Tecnologia, definindo-se a Arqueologia Industrial, segundo BUCHANAN, "como matéria de equilíbrio entre a teoria e a prática das pesquisas que são ou deveriam ser complementares e não opostas entre teóricos ou historiadores e práticos ou

\footnotetext{
${ }^{32}$ MENDES, J. Amado. Apud, Construção Civil e Patrimônio Industrial. Revista Mundo, Editora Tipografia Comercial Coimbra, Coimbra, 1983, p.35.

${ }^{33}$ BRAUDEL, Fernand. Civilização Material, Economia e Capitalismo. Ed.Martins Fontes, São Paulo, 1998.

${ }^{34}$ MENDES, José Amado. A Arqueologia Industrial ao serviço da história local. In Revista de Guimarães, № 105, Guimarães, 1995, p.236.

${ }^{35}$ JORGE, Vitor Oliveira. Projectar o Passado. Ensaios sobre Arqueologia e Pré-História. Ed. Presença, Lisboa, 1987, p.75.
} 
arqueólogos". ${ }^{36}$ Hodder, corrobora com essa assertiva, quando afirma que a Arqueologia deveria restabelecer seus laços tradicionais com a História. ${ }^{37}$

Segundo Pradayrol, 1985, l'archéologie industrielle doit préserver un mélange indissociable de techniques, de méthodes, et de matériels, faits par l'homme et pour l'homme. ${ }^{38}$

A Arqueologia Industrial no estudo de toda evidência, material ou imaterial, de documentos, artefatos, estratigrafia e estruturas, assentamentos humanos em terrenos naturais e urbanos, criados por processos industriais ou para eles, faz uso dos métodos de investigação/pesquisa mais adequados para melhor entender o passado e o presente industriais. ${ }^{39}$

Por outro lado, sua metodologia não adota a escavação, como técnica de investigação, seus estudos se baseiam em pesquisas de superfície, em fontes documentais, vestígios de antigos maquinários, imóveis fabrís e nos equipamentos coletivos das sociedades industrializadas.

Sua variante metodológica aplicada a um tema específico, a indústria, utiliza como fontes essenciais e primárias os vestígios materiais que a história não pesquisa. Portanto, respaldada nos métodos arqueológicos de levantamento em campo, analisa o patrimônio industrial, em seu sentido lato, suas características funcionais desde sua origem e todas as transformações por ele sofridas. Pesquisa 0 desenvolvimento e aperfeiçoamento de processos tecnológicos, inserindo-os em seu contexto espaço-tempo, ao estudar as estruturas fabris, às vezes desaparecidas, ampliações e reduções da edificação, segundo a necessidade de cada época, materiais empregados, instrumentos, ferramentas e técnicas utilizadas.

\footnotetext{
${ }^{36}$ BUCHANAN, Robert Angus. The Definition of Industrial Archeology in L'Étude et la Mise en valeur du Patrimoine Industriel. 4ํ Conférence internationale Lyon, Grenoble, Ed. du Centre National de la Recherche Scientifique, Paris, 1985, p.87.

${ }^{37}$ HODDER, lan. Interpretación En Arqueología.Corrientes Acutales. Ed. Crítica, Barcelona, 1994, p.93.

${ }^{38}$ PRADAYROL, Jacques. "Les chemins de Fer Touristiques". Pionniers de L'Archéologie Industrielle en France. In L'Étude et la Mise en valeur du Patrimoine Industriel. 4ํㅡㄹ Conférence internationale Lyon, Grenoble, Ed. du Centre National de la Recherche Scientifique , Paris, 1985, p.79.

${ }^{39}$ Carta de Nizhny Tagil de 2003, sobre o Patrimônio Industrial, elaborada pelo TICCIH (The International Committee for the Conservation of the Industrial Heritage, O TICCIH, é a organização mundial encarregada do patrimônio industrial, e assessor especial de ICOMOS nessas questões. $O$ texto desta carta foi aprovado pelos delegados reunidos na Assembléia Nacional do $\mathrm{TICCIH}$, de caráter trienal, que teve lugar em Moscou a 17 de julho de 2003. No Brasil, a seção nacional deste Comitê, foi inaugurada em Novembro de 2004, na UNICAMP - Campinas - São Paulo.
} 
Uma vez que a Arqueologia Industrial é o estudo dos vestígios remanescentes do passado industrial, the fieldwork is essentially an outdoor activity, can comprise locating, inspection, interpreting, surveying and measuring, and photographing or sketching industrial sites and structures. It is complementary to documentary work which in some cases might precede fieldwork, or in other instances follow it. ${ }^{40}$

A muldisciplinaridade de que faz uso a Arqueologia Industrial se imbrica e realiza sua síntese utilizando, portanto, o aporte de outras ciências como a geografia física e econômica, a química, a física, o direito, a história social, econômica, do trabalho, das ciências, da técnica, da engenharia, da arte, da arquitetura, das cidades e outras e, por esse motivo, o estudo do mecanismo de interpretação de disciplinas, algumas vezes afastadas umas das outras, se restringe ao ponto de vista prático e metodológico da investigação.

Complementa-se o trabalho de campo, com a consulta a outras fontes, como documentos escritos e iconográficos que incluem: atos oficiais, decretos e leis, relatórios de órgãos públicos do poder Executivo, catálogos, correspondência interna das empresas, atas de assembléia, manuscritos, projetos de invenções, anuários estatísticos, propagandas, estatutos societários (contratos), solicitação e registro de patentes, plantas, mapas, croquis, desenhos, telas, fotografias, e outros.

Tais fontes podem ser encontradas nos arquivos públicos, porém, parte dessa documentação ainda está em mãos de particulares, cujo acesso depende da postura dos proprietários com relação à sua salvaguarda.

Completa-se o estudo, com a pesquisa em jornais, revistas técnicas, microfilmagens, biografias, teses, visitas a museus, cujo acervo preserva ferramentas, antigas máquinas, veículos, moldes de artefatos industriais, desenhos, artes e ofícios, filmes e vídeos, que documentam um processo ou uma técnica de produção já desaparecidos, além do inquérito oral. ${ }^{41}$

A metodologia compreende a investigação e a análise de tipo do monumento ou estrutura em uma perspectiva regional e nacional, diacrônica e espacial e o estudo de seus aspectos tecnológicos, econômicos ou humanos. Ambas as estratégias metodológicas envolvem pesquisas em vários tipos de fontes, que se

\footnotetext{
${ }^{40}$ JONES, William. Dictionary of Industrial Archaeology. 2ed., Sutton Publishing. London, U.K., 2006, p.136.

${ }^{41}$ PANNELL, J.P.M. The Techniques of Industrial Archaeology. Ed. by J.Kenneth Major. Great Britain., 1974.
} 
complementam, mas cujo resultado final está relacionado com o exame, estudo, observação e avaliação dos vestígios materiais.

O arqueólogo industrial trabalha, como qualquer outro arqueólogo, com evidências de campo e, para efeito desta tese, respaldados nos autores anteriormente citados, conciliou-se o método arqueológico de campo - pesquisa, estudo e registro, com a vertente histórica da interpretação das fontes materiais e documentais que se encontravam disponíveis, de forma a reconstituir uma visão panorâmica da infra-estrutura do abastecimento de água na cidade de São Paulo, no final do século XIX e início do XX. ${ }^{42}$ (BUCHANAN, 1985)

Por intervenção arqueológica não deve se entender apenas a prospecção no subsolo.

(...) a arqueologia não tem um único método, mas vários; e a arqueologia industrial, como arqueologia que é, tem apenas a marcála a diferença de muitos dos seus vestígios se encontrarem à superfície, dispensando assim, na maioria dos casos, a utilização de técnicas de escavação. ${ }^{43}$ (RIBEIRO, 1990)

A investigação arqueológica dos sítios se processou em três níveis: o construído, o lugar e o território, com a análise e avaliação do patrimônio para o esclarecimento e a compreensão desses equipamentos coletivos industriais do passado, consistindo na pesquisa dos vestígios de superfície que, ao serem investigados, permitiram extrair informação elucidativa acerca dos tipos de materiais empregados e sua evolução à luz da seqüência lógica do devir temporal. ${ }^{44}$

Ao contrário de vestígios arqueológicos de estruturas menos visíveis, 0 conjunto das edificações, objeto deste estudo, inserido na paisagem, não exigiu

\footnotetext{
${ }^{42}$ BUCHANAN, Robert Angus. The Definition of Industrial Archeology in L'Étude et la Mise en valeur du Patrimoine Industriel. 4ํㅡㄹ Conférence internationale Lyon, Grenoble, Ed. du Centre National de la Recherche Scientifique, Paris, 1985, p.86.

${ }^{43}$ RIBEIRO, Isabel e SANTOS, Luísa. A indústria do papel na perspectiva da Arqueologia Industrial. In I Encontro Nacional sobre o Património Industrial. Editora Coimbra, Coimbra, 1990, p. 485.

${ }_{44}$ Segundo Engels "para a dialética não há nada de definitivo, de absoluto, de sagrado; apresenta a caducidade de todas as coisas e em todas as coisas e, para ela, nada existe além do processo ininterrupto do devir e do transitório. Nada é sagrado significa que nada é imutável, que nada escapa ao movimento, à mudança. Devir expressa que tudo tem uma 'história'". ENGELS, Friedrich apud LAKATOS, Eva Maria. Fundamentos de Metodologia Científica, São Paulo, ed Atlas, 1991, p.103.
} 
trabalho de escavação. Para descrição e localização geográfica do sítio industrial, utilizou-se cartas topográficas, hidrográficas antigas e atuais, fotografias de satélite e aéreas para georeferenciá-lo. Foram feitas, também em campo, medições nas construções, levantamento fotográfico do sistema construtivo e a análise de seu estado atual, de materiais e tecnologia utilizados em sua construção, acréscimos e modificações que sofreram por ações antrópicas ou não, e também, comparações com outras estruturas similares.

Portanto, é no trabalho de campo que reside a grande força das técnicas de investigação da Arqueologia Industrial. A análise do vestígio material deverá ser a mais detalhada e minuciosa possível, com a elaboração de fichas de inventário com vista ao estabelecimento de um diagnóstico para a compreensão de sua situação atual, fornecendo as bases que possibilitem avaliar o objeto de estudo durante seu período de vida.

Equipamento coletivo, o abastecimento de água, é também considerado obra pública e, segundo Ordónez, 1990, "desde tiempo immemorial, por medio de las Obras Públicas, el hombre configura el espacio y se apropía de él, lo señala y significa creando um lugar em sentido heideggeriano. Em effecto, las Obras Públicas no son solo monnumentos aislados em la naturaleza, sino que forman um tejido que soporta y hace posibles las relaciones sociales, y tienen um valor arqueológico, simbólico, estético, histórico, tecnológico y funcional que nos obligan a uma preservación inteligente". 45

Para a interpretação dos vestígios do abastecimento de água, foi necessário um levantamento dos arquivos públicos e privados, a fim de que o estudo pudesse ser elaborado de forma mais precisa e sistemática possível, para sua contextualização no espaço e no tempo, o que permitiu um maior conhecimento das técnicas, processos e métodos de trabalho empregados.

\footnotetext{
${ }^{45}$ ORDÓNEZ, José Antonio Fernández. "Informe sobre la situación de la Arqueología Industrial y el Patrimonio de Obras Públicas en los países europeos del Mediterráneo y propuestas de acciojnes a emprender para su conservación y reutilización", In Mercedes Lopez Garcia. La Obra Publica, Investigacion y Practica. I Encontro Nacional sobre o Património Industrial. Vol.II, Ed. Coimbra, Coimbra, 1990, p.281.
} 
A arqueologia industrial deve seguir os preceitos do pósprocessualismo, exercitando constantemente a compreensão da interação do passado no presente entre indivíduos e sociedades e a cultura material que as produziu e as envolve, de acordo com lan Hodder. ${ }^{46}$ (JAUME, 2004)

Portanto, sendo sua maior interface com a História, no estudo da cultura material das sociedades industrializadas, associa os métodos arqueológicos aos históricos regressivo, progressivo e comparativo.

O método regressivo, importante auxiliar na Arqueologia Industrial, assenta suas bases no procedimento regressivo que havia sido aplicado às presenças agrárias na França por Marc Bloch, em 1935. ${ }^{47}$ Segundo Custódio, utilizando este método, "o arqueólogo industrial tem apenas que saber interpretar os dados fornecidos pelas presenças físicas que se encontram no terreno e delas fazer o instrumento de clarificação do lugar". ${ }^{48}$

O método regressivo, partindo de um presente que se oferece para um passado pouco conhecido, constitui um tipo de investigação que se processa no sentido inverso do tempo, ou seja, tal como nos diz MARCH BLOCH, 1935, (...) "só está intacta a última película. Para reconstruir os vestígios apagados dos restantes é forçoso primeiro desbobinar a película no sentido inverso das filmagens. ${ }^{, 49}$

Utilizando o método regressivo na análise dos vestígios industriais legados durante esses últimos duzentos anos, partimos do presente para o passado, estudando simultaneamente os gestos e os hábitos inerentes à atual sociedade capitalista.

Percebemos a interligação com a Revolução Industrial, ou seja, a mecanização dos nossos hábitos e a medição individual do tempo ligada ao modo de produção, com a banalização dos bens e com a necessidade de substituição

\footnotetext{
${ }^{46}$ JAUME, Valentines Alvarez. Arqueologia Industrial I Ecomuseografia a Les Universitats. El Cãs de L'ETSEIB, In Quaderns d'Història de L'Enginyeria. Vol. VI, Barcelona, 2004, p.140.

${ }^{47} \mathrm{BLOCH}$, Marc. Caractéres Originaux de L'Histoire Rurale Française. Paris, 1935, p.86.

${ }^{48}$ CUSTÓDIO, Jorge. Método Comparativo e Método Regressivo na Detecção do Moinho Gigante do Barão do Sobral erigido no Barreiro. In I Encontro Nacional sobre o Património Industrial, Editora Coimbra, vol. II, 1990, p.744.

${ }^{49}$ HENRIQUES, Isabel. A Fábrica da Companhia de Cerâmica de Telheiras. Algumas questões de método. In I Encontro Nacional sobre o Património Industrial. Ed.Coimbra, Coimbra, 1990, p.211.
} 
constante dos produtos, cada vez mais diversos e condicionantes da mutação do nosso cotidiano. ${ }^{50}$

O método comparativo, de larga aplicação nas vários ramos das ciências, realiza analogias, tendentes a apontar as similitudes e explicar as divergências. Permite, uma análise das técnicas, e da tecnologia empregadas em outras realidades, e em outros momentos históricos, estudando os meios que o homem descobriu e utilizou para melhorar as condições de sua existência: as circunstâncias da invenção, sua transmissão coletiva e as relações entre ciência e técnica. ${ }^{51}$

Esse método, segundo Custódio ${ }^{52}$, deve ser utilizado para se estabelecerem os paralelos tecnológicos do objeto em estudo, sendo possível levar mais longe o diagnóstico, no sentido de proporcionar uma maior compreensão das relações que se estabelecem entre história, indústria, técnica e cultura.

A aplicação simultânea dos métodos comparativo e regressivo deve ser acompanhada da pesquisa e do estudo de documentos escritos e iconográficos. Quanto maior for o leque de informações que se possa recolher sobre o objeto em análise, tanto mais acurada poderá ser sua interpretação.

A partir desse momento, propõe-se a utilização do método progressivo, ${ }^{53}$ isto é, volta-se ao presente, a partir do passado já decifrado, compreendendo-se, enfim, o tempo em que se altera a própria história, nesse espaço em transformação, que é a cidade de São Paulo do final do século XIX e começo do XX, despontando para uma metrópole industrial onde, de acordo com o método de Lefebvre, existem três espacialidades: a primeira, da localidade (rural); a segunda, do bairro (industrial) e a terceira, da porção imersa na metrópole (serviços). ${ }^{54}$

Portanto, nessa trialética, passado, presente e futuro, se delineiam os caminhos da mudança, atribuindo-se à industrialização fator de importância capital nas reformulações tecnológica, econômica, social e filosófica das sociedades modernas.

\footnotetext{
${ }^{50}$ FOLGADO, Deolinda. Instituto Português do Património Arquitectónico: Inventário do Património Industrial. In Património Edificado.Novas Tecnologias.Inventários.Editora do Instituto Açoriano de Cultura. Angra do Heroísmo, 2002, p.215.

${ }^{51}$ DUMAS, Maurice, apud ANDRIEUX, Jean-Ýves. "Que sais-je? Le Patrimoine Industriel. Presses. Universitaires de France, Paris, France, 1992, p.105.

${ }^{52}$ CUSTÓDIO, Jorge. Método Comparativo e Método Regressivo na detecção do Moinho Gigante do Barão do Sobral, erigido no Barreiro. In I Encontro Nacional sobre o Património Industrial. Vol II, Editora Coimbra, Coimbra, 1990, p.745.

${ }^{53}$ LEFĖBVRE, Henry. De lo Rural a lo Urbano. Ed. Península, Barcelona, 1978, p.2.

${ }^{54}$ LEFÉBVRE, Henry. A Revolução Urbana. Ed. UFMG, Belo Horizonte, 2004, p.44/445.
} 
Podemos entender a Arqueologia Industrial como um elo que nos liga ao passado e, simultaneamente, nos projeta no futuro, tornando o arqueólogo industrial um personagem interveniente, com papel ativo a desempenhar nos quadros da sociedade atual. ${ }^{55}$

${ }^{55}$ RIBEIRO, Isabel e SANTOS, Luísa. A indústria do papel na perspectiva da Arqueologia Industrial. In I Encontro Nacional sobre o Património Industrial. Editora Coimbra, Coimbra, 1990, p. 485. 


\section{GESTÃO DAS ÁGUAS NA SERRA DA CANTAREIRA NO SÉCULO XIX}

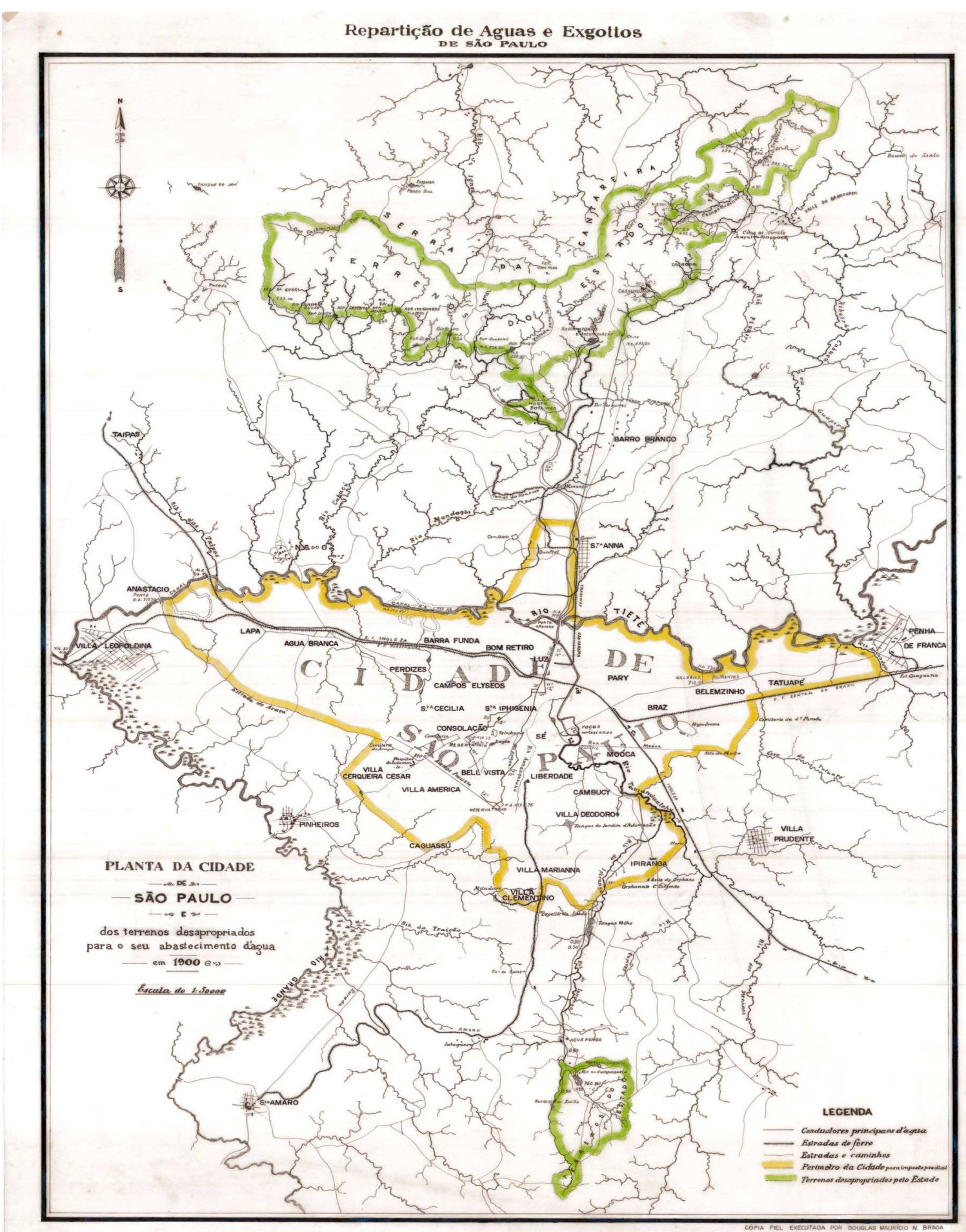

Áreas desapropriadas para o abastecimento de água, com destaque em verde.

No mapa acima: Serra da Cantareira, origem do Parque Estadual da Cantareira e, abaixo, a Bacia hidrográfica do Ypiranga, atual Parque Estadual das Fontes do Ipiranga. 
Atualmente a Gestão das Águas é definida como o:

Conjunto de procedimentos organizados no sentido de solucionar os problemas referentes ao uso e ao controle dos recursos hídricos. $\mathrm{O}$ objetivo da gestão é atender, dentro das limitações econômicas e ambientais e respeitando os princípios de justiça social, à demanda de água pela sociedade com uma disponibilidade limitada". ${ }^{56}$ (CAMPOS, 2003)

Porém, o modelo da "gestão das águas" vigente no século XIX, se por um lado se preocupava com a preservação ambiental, desapropriando os terrenos onde se situavam as nascentes a serem captadas, por outro, não estava baseado em justiça social e não contava com a participação popular nas decisões, dentro da visão de uma sociedade autoritária, elitista, ainda agro-exportadora, cujos acanhados horizontes políticos, não permitiam alcançar a extensão da importância que a água representava, como um bem que deveria ser garantido, a todos os habitantes da Paulicéia.

A pesquisa, procurou relatar as funções que foram desempenhadas pela administração pública, com sua forte intervenção, no desenvolvimento e gerenciamento dos recursos hídricos na Serra da Cantareira, justificada pelas características das atividades de um setor que lidava com um bem público, a água.

Para tanto, foi necessário o resgate histórico dos instrumentos utilizados na demanda da água, as medidas conjunturais, e as intervenções diretas realizadas com a atuação de outros segmentos da sociedade paulistana, como era o caso da Companhia Cantareira, os aspectos técnicos, os condicionantes políticos e econômicos que foram de fundamental importância para a estrutura do abastecimento de água daquele período.

Até a segunda metade do século XIX, a capital paulista apresentava um aspecto de cidadezinha provinciana, e uma precária situação financeira, que obrigava a edilidade a recorrer aos cofres do governo provincial ${ }^{57}$ para a realização das necessárias e urgentes obras de infra-estrutura, de uma cidade em busca do surto de progresso político, econômico, cultural, social, demográfico e urbano,

\footnotetext{
${ }^{56}$ CAMPOS, Nilson et all. Gestão das Águas. Princípios e Práticas. Ed. da Associação Brasileira de Recursos Hídricos. Porto Alegre, 2003, p.45.

${ }^{57}$ Nessa época o Presidente da Província era o responsável pela capital. Não havia o cargo de prefeito, criado apenas em 1898, sendo seu primeiro ocupante o Conselheiro Antonio da Silva Prado; separam-se, então,a esfera Estadual da Municipal.
} 
incentivada pelos adventos do complexo cafeeiro, da construção da estrada de ferro Santos-Jundiaí (1867) e do afluxo de imigrantes europeus.

Com relação ao saneamento, o auxílio das rendas da Província, tornou possível a multiplicação de tanques e chafarizes, sua contribuição, porém, sempre foi insuficiente, para amenizar o grave problema do abastecimento de água, a uma população que com seu natural crescimento, sentia, em proporção equivalente, a escassez do líquido, sendo obrigada, para dessedentar-se, a recorrer às suspeitíssimas águas do Tamanduateí, oferecidas pelos "aguadeiros", de porta em porta, em pipas puxadas por burros, por preços que variavam de 40 a 80 réis o barril de 20 litros. O alvo, de tão próspero comércio, eram as famílias que não possuíam escravos para buscar água nas fontes.

Em 1852, o Presidente da Província de São Paulo, encarregou uma comissão de engenheiros para procurar novos mananciais de água ao redor da cidade. Os estudos apontaram as fontes do Pacaembu, e as águas na Serra da Cantareira, como solução para o abastecimento. ${ }^{58} \mathrm{Em}$ abril desse ano, a comissão concluiu que embora mais próximas, a pequena quantidade de água inviabilizava as fontes do Pacaembu. Porém, as águas potáveis que nascem nas vertentes da Cantareira, com regime fluvial intermitente, devido a sua abundância, seriam a solução definitiva para a cidade. ${ }^{59}$

"O Conselho d'Engenheiros commetteu aos engenheiros Porfirio de Lima, e C. A. Bresser os exames necessários para se reconhecer a possibilidade de se encanar as agoas da Cantareira." 60

Em 1855, José Antonio Saraiva, chefe do Executivo paulista, propõe que as obras sejam feitas por uma empresa privada: "Se com essa despeza se podesse conseguir trazer a Capital, as águas da Cantareira certamente vos aconselharia, que

\footnotetext{
${ }^{58}$ Relatório referente ao discurso do Sr José Thomaz Nabuco d'Araujo, Presidente da Provincia de São Paulo abrindo a Assembléia Legislativa Provincial no dia 1ํ de maio de 1852. Typ.do Governo arrendada or Antonio Louzada Antunes.São Paulo, p. 2 e p.52

${ }^{59}$ Relatório referente ao discurso do Sr José Antonio Saraiva, Presidente da Província de São Paulo, na Assembleia Provincial no dia 15 de fevereiro de 1855.Typographia 2 de Dezembro de Antonio Louzada Antunes, São Paulo,p. 32,33

${ }^{60}$ Relatório geral das obras publicas apresentado pelo Conselho d'Engenheiros, em 20 de março de 1852 em cumprimento ao $\S 3^{\circ}$ do Art 3을 do Regulamento de 04 de Outubro de 1851. Acervo do Arquivo do Estado de São Paulo, Setor de Manuscritos Obras Publicas, Anos de 1850 a 1855, Caixa 14, Ordem 5151, Doc C14 P3 93 A. A Comissão era formada por Henrique de Beaurefair Rohan, Luiz José Monteiro, José Jacques da Costa Ourique, José Porfirio de Lima, H Bastide, Carlos Abraão Bresser e Mariano Gonçalves Gomide
} 
tratasseis de auxiliar a organisação de uma companhia, que fizesse desse encanamento uma empresa particular." ${ }^{.61}$

Com base nos pareceres da Comissão de Engenheiros, a Assembléia Legislativa promulga a Lei 29 de 08 de abril de 1857, autorizando o Governo a contratar com Achilles Martin d'Estadens ${ }^{62}$ o encanamento das águas dos ribeirões na Serra da Cantareira com a condição de fornecer cem mil medidas de água por dia para um reservatório que deveria ser construído na Consolação, com encanamentos de ferro laminados, revestidos com betume, com duas polegadas de diâmetro. As autoridades ficariam com os encargos da desapropriação dos terrenos particulares por onde passaria a canalização. ${ }^{63}$

Porém, como as obras não tiveram início, o Presidente da Província sancionou a Lei oㅜ 27 de 11 de maio de 1859, que alterava o artigo $1^{\circ}$ da Lei $n^{\circ}$ 29/1857:

"Artigo 25

§ 1ㅇ O Governo contractará o encanamento das agoas da Cantareira com quem melhores vantagens offerecer, autorizando a ampliar o systema n'essa lei approvado."64

Todavia, a maior polêmica se estabeleceu com relação ao inciso $2^{\circ}$, que determinava que as obras ficariam sob a inspeção do governo provincial, e que a Câmara Municipal deveria arcar com dois terços dos recursos e a província com um terço, mas, permitia que a edilidade pudesse contrair empréstimos e ainda vender antecipadamente as penas d'água aos interessados. O que chama a atenção nessa documentação ${ }^{65}$, é que o debate fica circunscrito apenas ao inciso primeiro,

\footnotetext{
${ }^{61}$ Relatório referente ao discurso do Sr José Antonio Saraiva, Presidente da Província de São Paulo, na Assembleia Provincial no dia 15 de fevereiro de 1855.Typographia 2 de Dezembro de Antonio Louzada Antunes, São Paulo,p. 32,33

${ }^{62} \mathrm{Na}$ documentação legal é tratado apenas como contratador. O francês Achille Martin d'Estadens é citado por Eudes Campos, como empreiteiro de obras públicas, no artigo "São Paulo: desenvolvimento urbano e arquitetura sob o Império" in História da Cidade de São Paulo - A cidade no Império 1823 - 1889, Ed Paz e Terra, São Paulo, p. 206.

${ }^{63}$ SÃO PAULO. Collecção de Leis da Assembléia Legislativa Provincial do ano de 1857, Typografia Dous de Dezembro de Antonio Louzada Antunes, 1857, p.17.

${ }^{64}$ SÃO PAULO. Colecção de Leis da Assembléia Legislativa Provincial do ano de 1859, Typografia Dous de Dezembro de Antonio Louzada Antunes, 1859, p.80.

${ }^{65}$ A documentação está arquivada no Departamento de Patrimônio Histórico da Prefeitura de São Paulo. Foram consultadas as Atas da Câmara Municipal e a coleção de Leis e Decretos onde se pode observar acirrados debates entre os dois poderes, o provincial e o municipal.
} 
passando despercebido o 70: "Depois de concluída a obra, os lucros que houverem das pennas vendidas serão divididos entre a Província e a Câmara Municipal". ${ }^{66}$

O custo para implantação de uma inovação técnica, exerce uma influência no sentido inversamente proporcional à sua introdução. Em geral, quanto maior o seu custo, maior a dificuldade para sua inserção.

Um ano depois, a Câmara Municipal, ainda reclamando do inciso primeiro do artigo 25 da Lei o 27 de 11 de Maio de 1859, resolve angariar recursos vendendo antecipadamente a instalação de penas d'água, concluindo que não seria possível obter o capital necessário para as obras.

Desde 1857, a edilidade acreditava que o único sistema confiável para a adução das águas, seria o emprego de encanamentos revestidos internamente com uma camada de porcelana vitrificada, para impedir a oxidação e vedar o contato das águas com o ferro, sistema conhecido como Chameroy ${ }^{67}$ o que elevava o custo do empreendimento.

O Secretário de Obras Públicas, no relatório enviado em 1862, critica essa exigência, argumentando que não tinham consistência os projetos apresentados, pela ausência de uma planta topográfica da cidade, que orientasse os engenheiros para os tipos de encanamentos que deveriam ser empregados, e os recursos necessários para que tal investimento desse bons resultados.

"Bem avizadas andarão as Provincias de Pernambuco e Alagoas, que fizerão ir as respectivas localidades estudar todos os accidentes do terreno e todas as condições da obra os distintos engenheiros, e só depois de levantada a planta e feito o competente orçamento, emprehenderão e levarão a effeito com o melhor successo o encanamento de agoas para as suas respectivas Capitáes.

Penso que deveis proceder com igual prudencia, autorisando o contracto com um Engenheiro, reconhecidamente habilitado, que venha a Provincia fazer estes estudos previos". 68

Enquanto os debates prosseguiam, o jornal Correio Paulistano de 28 de fevereiro de 1863, alertava que o quadro de carência permanecia inalterado:

\footnotetext{
${ }^{66}$ SÃO PAULO. Colecção de Leis da Assembléia Legislativa Provincial do ano de 1859, Typografia Dous de Dezembro de Antonio Louzada Antunes, 1859, p.80.

${ }^{67}$ Relatório com que o Conselheiro Antonio José Henriques, Presidente da Província de São Paulo abriu a Assembléia Legistiva Provincial no ano de 1861. Tip Imparcial, p.16

${ }^{68}$ Relatório apresentado a Assembléia Legislativa da Província de São Paulo na $1^{\text {a }}$ Sessão da 14a Legislatura pelo Presidente da Província Dr João Jacintho de Mendonça,Typographia Imparcial, 1862, p. 41.
} 
"Todos os dias sentem-se mais a falta de agua nesta cidade.O actual encanamento, além de defeituoso, não tem a capacidade precisa para conduzir as aguas fornecidas pelas vertentes; os tubos, já em si pequenos, tendem continuadamente a obstruir-se pela argila que dissolvida na agua, vae-se acumulando no interior delles, e d'aqui resulta que os chafarizes da cidade são cada vez menos bem alimentados, e isto ao passo que o crescimento da população desenvolve-se com extraordinaria rapidez". 69

Ainda na mesma notícia temos:

"Várias propostas forão offerecidas à Presidencia para o encanamento das aguas da Cantareira; estas propostas, mais ou menos onerosas à Província, forãovos todas apresentadas, e ainda não tiverão solução"70

Nessa época, a população urbana era de aproximadamente vinte mil habitantes e dispunha, a cada 24 horas, de 17.000 canadas $^{71}$ de água que equivalem a 45.254 litros, cerca de um pouco mais de 2 litros per capta. ${ }^{72}$

Entre as duas décadas de 1850 e 1870, pode-se notar os primeiros sintomas de mudança na mentalidade paulistana, conservadora, que se vê obrigada a aceitar os desafios, daqueles que tentavam fazer de São Paulo uma "urbe eficiente". Tem início a preparação da cidade capitalista: setores de sua elite, impregnados agora pela visão mecanicista, própria do progressismo burguês, com empenho reivindicavam melhorias urbanas. Procuravam entronizar em seu mundo, uma ordem geral, que correspondia à lógica da mercadoria, realizada em escala mundial pelo capitalismo e pela burguesia.

As autoridades, catalisando esses anseios e desconsiderando a "tecnologia implícita"73 de nossos técnicos, decidem entrar em contato com o Superintendente

\footnotetext{
${ }_{70}^{69}$ Correio Paulistano, ำ2335, de 28 de Fevereiro de 1864, p.02

${ }^{70}$ Ibidem p.02

${ }^{71}$ Uma canada é igual a 2,662 litros.O sistema de pesos e medidas usado naquele período foi substituído pelo sistema métrico francês pela Lei o 1157 de 26 de junho de 1862.in Brasil, Leis e Decretos, Lei ํo 1.157 de 26 de junho de 1862. Substitue em todo o Imperio o actaual systema de pesos e medidas pelo systema metrico francez.

72 JORGE, Clóvis de Athayde. Consolação uma reportagem histórica, Departamento do Patrimônio Histórico. Divisão do Arquivo histórico, Divisão Gráfica Municipal, São Paulo, s/data, pp 98.

${ }^{73}$ Termo usado por Milton Vargas ao discutir o conceito de tecnologia de Victor Freire, que foi professor, em 1893, do Curso de Engenharia Civil da Politécnica, quando este chama a atenção para o fato de que a obra de engenharia deveria subordinar-se às condições de ser "resistente" e "duradoura", o que se conseguiria pela obediência, por parte do empreiteiro, às "especificações da obra", as quais deveriam compreender sete itens por ele enumerados. Os dois primeiros correspondem a conhecimentos adquiridos pelo engenheiro nas escolas de engenharia. Diz ele: "a técnica especial e a respectiva tecnologia constitui o assunto de cadeiras separadas, que figuram no programa das escolas de engenharia". Para Vargas, aqui aparece o que ele chama de "tecnologia
} 
da Companhia de Estradas de Ferro, para que mandasse vir de Londres um engenheiro capaz de executar um plano de obras.

Em 1863, foi indicado o inglês, James Brunless, presidente do Instituto de Engenheiros Civis de Londres, que também seria contratado para a construção da estrada de ferro da São Paulo Railway, tendo sido o autor em 1865, do viaduto da Grota Funda na Serra do Mar, uma das obras mais brilhantes do complexo ferroviário paulista, sendo executada totalmente em ferro, uma revolução para a provinciana São Paulo daquela época.

A instalação da ferrovia, ligando o interior da Província ao porto de Santos, passando pela capital paulistana, solucionou o problema do escoamento da produção cafeeira. Sua construção atraiu grande número de engenheiros estrangeiros e vários desses profissionais acabaram se envolvendo em outras obras realizadas na cidade.

Em 1864, Brunless, auxiliado por seus colegas Hooper e Daniel Mackinson Fox, funcionários da São Paulo Railway, apresentaram um relatório favorável à adução das águas do ribeirão da Pedra Branca, na Serra da Cantareira, uma vez que satisfazia os requisitos de qualidade e quantidade ${ }^{74}$. (FREITAS, 1929)

Sem os recursos financeiros necessários, esse projeto, assim como os anteriores apresentados em outras ocasiões, foi abandonado e o fornecimento continuou calamitoso, no momento em que a explosão demográfica começava a atingir um ritmo vertiginoso.

Em 1866, o Poder Executivo sanciona outra lei, a de ㄲo 72 de 20 de maio, onde o coronel Joaquim Floriano de Toledo, que assinava como Oficial da Ordem da Rosa, Cavaleiro da Ordem do Cruzeiro e de Cristo, fazia saber aos habitantes:

"Artigo $1^{\circ} \mathrm{O}$ governo fica autorizado à contractar, com quem mais vantagens offerecer, o encanamento das agoas da Cantareira, sob as condições seguintes:

implícita" nos ensinamentos de engenharia se referindo às aplicações da ciência que são ensinadas aos alunos das escolas de engenharia, com relação ao projeto e à construção dos vários ramos dessa profissão.(grifo nosso). Os cinco itens seguintes que devem constituir as "especificações incluem: qualidade de materiais, processos de construção da obra, ensaios de materiais da própria obra e condições de preço, prazo e processos de litígio. Isso seria, segundo ele, a "esfera de ação que se denomina tecnologia geral" in VARGAS, Milton.Org. O início da pesquisa tecnológica no Brasil. In História da Técnica e da Tecnologia no Brasil. São Paulo, Editora UNESP, 1994, p. 214.

74 FREITAS, Affonso A. de. Diccionario Historico, Topographico, Ethnographico Illustrado do Município de São Paulo. Tomo I. SP: Graphica Paulista, 1929.p. 59. 
$\S 1^{\circ}$ O governo Provincial solicitará do geral, privilégio até cincoenta anno, em favor da Companhia ou indivíduo com quem fizer contracto.

$\S 2^{\circ}$

$\S 3^{\circ}$ O Governo fica autorizado a comprar para os estabelecimentos públicos da companhia ou contractador, a goa que precisar.

$\S 4^{0}$ Fica igualmente autorizada a Câmara Municipal da Capital à comprar agoa que precisar para os chafarizes públicos.

§ 5 A Companhia ou contractador obrigar-se-há à dar gratuitamente, quatro chafarizes, sendo dous para a Freguesia da Sé, e um para cada um das Freguesias do Braz e Santa Ephigênia, maarcando os logares onde deverão elles ser postos.

Art. $2^{\circ} \mathrm{O}$ governo não garante juros, e nem se compromette à dar subvenção algum à Companhia ou Contractador.

Art. 3 Feito o contracto, pela forma marcada, o governo fica autorizado à rescindir qualquer contracto existente segundo as condições de direito". ${ }^{75}$ Não apareceu nenhum interessado.

O Conselheiro Saldanha Marinho, relata em 1868 com certo preconceito:

"Desde que me acho na administração desta Provincia recebo reclamações para providenciar em bem deste melhoramento que é o abastecimento de agua potável à Capital.

$\mathrm{Na}$ verdade os habitantes da Capital estão pessima e escassamente servidos de agua.

Os mais ricos podem abastecer as suas casas empregando em tal serviço escravos que assim distrahem quasi completamente de outras ocupações. Os outros compram-na má e por preço elevado; todos se queixam com razão de que não tem agua, nem sufficiente, nem perfeitamente potável para seu uso." ${ }^{\text {76 }}$

O Presidente da Província, Antonio Cândido da Rocha, em 1869, suspende os recursos públicos destinados ao Inspetor de Obras que persistia na ampliação do antigo tanque Municipal, de onde provinham as águas para a cidade.

Para ele, somente as águas do ribeirão da Pedra Branca, na Cantareira poderiam solucionar a escassez no abastecimento, e propunha uma singularidade: a

\footnotetext{
${ }^{75}$ SÃO PAULO. Collecção de leis da Assembléia Legislativa Provincial promulgadas no ano de 1866 e dos regulamentos expedidos para execução das mesmas. Typ. Imparcial de Azevedo Marques, 1866, pp 174,175.

${ }^{76}$ Relatório apresentado a Assembléa Legislativa Provincial de São Paulo no dia 2 de Fevereiro de 1868 pelo Presidente da mesma Província o Conselheiro Joaquim Saldanha Marinho.Typographia do Ypiranga, 1868, p.81.
} 
captação das águas do rio Tamanduateí, elevadas por meio de bombas a vapor, para um reservatório com altura suficiente para que chegassem com pressão à rede distribuidora. ${ }^{77}$ Este projeto foi logo abandonado devido à impureza do rio e ao custo da importação e manutenção dos equipamentos.

A Lei 102 de 30 de abril de 1870, que revogou a de nº72/1866 definia em seu Art. 2o "O governo da Provincia poderá, para levar a effeito tão importante melhoramento, contrahir um empréstimo, ou emitir tíitulos no valor de 650:000\$000 ao juro de 7 por cento ao anno.

Art. $3^{\circ}$

Art. $4^{\circ}$

Art $5^{\circ}$ Fica outrossim creado um imposto predial de 5 por cento sobre 0 aluguel das casas. ${ }^{78}$

$\S 2^{\circ}$ As casas que forem habitadas pelos proprietários, será arbitrado um aluguel.

Art. 6ㅇ - governo poderá conceder licenças para a venda de água em carroças ou por outro qualquer meio, mediante uma taxa anual de 50\$000, não podendo os concessionários cobrar mais de 40 réis por 26 litros. Fica subentendido que ninguém poderá vender água sem prévia licença, sob pena de incorrer numa multa de 100\$000, e o dobro na reincidência, devendo tais inspeções ser processadas como as de posturas municipais."79

Essa lei, autorizava o governo a abrir concorrência para o abastecimento com os mananciais da Cantareira e apresentava algumas novidades, como a criação de um imposto para subsidiar essas obras, e deixava claro que o governo detinha o monopólio das águas paulistanas, inclusive tabelando as águas fornecidas pelos aguadeiros.

O Estado passa a atuar com mais rigor e intervencionismo nas relações com os seus cidadãos, porém, de forma esparsa, mostrando a falta de uma visão mais ousada e integral da cidade. As críticas a esse descompasso, vinham muitas vezes da própria administração pública, como a do engenheiro João da Silva Coutinho e a

\footnotetext{
77 Relatório apresentado à Assembléia Legislativa Povincial de São Paulo pelo Presidente da Província Dr Antonio Candido da Rocha no dia 2 de fevereiro de 1870. Typographia Americana, 1870, p. 49.

${ }^{78}$ Esse imposto criado para auxiliar na captação de recursos para o abastecimento de água continuou a ser cobrado mesmo quando as obras passaram para a iniciativa privada.

${ }^{79}$ SÃO PAULO. Collecção de Leis e Posturas Municipaes promulgadas pela Assembléia Legislativa Provincial, Typographia Americana, 1871, pp195,196.
} 
do Inspetor Geral de Obras Públicas que alegavam não terem sido feitos estudos profundos sobre os projetos de canalização, e que mesmo Brunless, contratado em 1864, nunca havia medido a capacidade do riacho da Pedra Branca, e mesmo assim, prometia 60 litros diários por pessoa, para uma cidade de 50.000 habitantes. 80

Do ponto de vista tecnológico, deveriam ser vencidos mais de catorze quilômetros de encanamentos, para trazer a água até o centro, e depois distribuí-la aos usuários.

Durante o governo de João Teodoro, citado pelo historiador Eurípedes Simões de Paula ${ }^{81}$, como sendo o responsável pela "segunda fundação da cidade de São Paulo", nada foi feito para resolver o grave problema de abastecimento de água.

O seu sucessor, o Presidente da Província, Sebastião José Pereira, premido entre a urgência das providências e a alegando escassez de recursos, desconsidera a letra da lei, e sem concorrência pública ou parecer da Inspetoria de Obras, assina em 09 de outubro de 1875, com o Coronel Antonio Prost Rodovalho, o engenheiro Macckinson Fox e com o maior empreendedor imobiliário da Cidade, o major Benedito Antônio da Silva, um contrato, com força de privilégio para abastecer a cidade, utilizando-se de um sistema de canalização de água captada na Serra da Cantareira.

Segundo Eudes Campos ${ }^{82}$, uma mentalidade burguesa - valorizadora da racionalidade, competência e eficiência - só passou a predominar nas obras públicas provinciais a partir da administração de Sebastião José Pereira, com a reorganização da Diretoria de Obras Públicas, e com a nomeação, para o cargo de diretor, do engenheiro Elias Fausto Pacheco Jordão, primeiro paulista a se formar e doutorar em Cornell (EUA).

Apesar da aura de eficiência que o cercava, e de não confundir o público com o privado, tão comum em seus antecessores, sua escolha não recaiu em parâmetros

\footnotetext{
${ }^{80}$ Assim como Milton Vargas, em História da Técnica e da Tecnologia no Brasil,ed Unesp, 1994, podemos afirmar que essa discussão era característica da retórica que dominava os projetos daquela época.

${ }^{81}$ PAULA, Eurípides Simões de. A segunda fundação de São Paulo; da pequena cidade à grande metrópole de hoje. São Paulo, Revista de História, ano V, № 17, 1954, p.167.

82 CAMPOS, Eudes, "São Paulo: desenvolvimento urbano e arquitetura sob o Império" in História da cidade de São Paulo - A cidade no Império 1823-1889, Paz e Terra, São Paulo, 2004, p.215.
} 
de competência, e sim porque, "são cavalheiros bem conhecidos como incapazes de faltarem à palavra compromettida." 83

No Relatório apresentado à Assembléia Legislativa, Sebastião José Pereira, afirmava que seria utopia esperar que alguma empresa despendesse dinheiro para distribuir gratuitamente água pelas ruas e praças da Capital e que "forçoso era proporcionar-lhe meios de amortizar o capital dentro de certo período, de auferir lucros razoáveis". ${ }^{84}$ Para ele, era indispensável tornar obrigatório o fornecimento de água a todas as casas mediante cobrança, ou garantir direito exclusivo de vender água a todos que tivessem necessidade de comprá-la.

"Na 1"a hipótese havia ônus para toda a população.

$\mathrm{Na} 2^{a}$, limita-se a indústria de alguns indivíduos em benefício da sociedade; os aguadeiros serão prejudicados; lucrava, porém, toda a população". 85

A proposta correspondia a uma ideologia liberal, que aceitava a necessidade da intervenção pública em algumas matérias específicas, porém, ainda, sem alterar substancialmente o cotidiano da sociedade.

No entanto, as decisões que incidiam sobre as alterações na infra-estrutura, dependiam da existência de um centro de poder, de hierarquias sociais eficazes, em suma, de capacidade de coerção.

Percebemos a preocupação do Presidente da Província, em explicar que a população teria acesso aos mananciais do entorno da cidade, aos poços, aos rios e tanques já existentes, porém, estava proibida de negociar água, deixando explícito que não seriam mais admitidos os aguadeiros. Na época, circulavam denúncias de que alguns vereadores eram os verdadeiros donos das carroças dos aguadeiros e que por isso inviabilizavam qualquer medida que restringisse esta atividade.

A notícia do jornal Diário de São Paulo ilustra a afirmação anterior:

“... Acreditamos que não será para manter a pipa a "cento e vinte”, que dizem ser do Sr. Capitão reintegrado, ex tenente coronel Osório, Presidente da Câmara e outros que, além de venderem por bom preço, a 60 rs cada barril de seis medidas, vendem espuma de sabão e infusão de todas as coisas que infectam - o

\footnotetext{
${ }^{83}$ Relatório apresentado à Assembleia Legislativa Provincial de São Paulo pelo Presidente da Província Sr. Sebastião José Pereira, em 2 de Fevereiro de 1876,Typographia do Diário,p.05.
}

${ }^{84}$ Ibidem, p. 06

${ }^{85}$ Ibidem, p. 06 
Tamanduateí, onde a maior parte vai encher as pipas (!), segundo corre. E viva a câmara! Um munícipe". ${ }^{86}$

As transformações pelas quais, em breve, passaria a cidade quando se intensificasse a industrialização, não eram sentidas nesse momento, as autoridades procuravam remediar cada problema em particular, seguindo os habituais caminhos administrativos e imediatistas.

Observamos que as obras implicavam em recursos financeiros de que a municipalidade ainda não dispunha, embora as rendas do município que entre 01 de julho de 1863 a 30 de junho de 1864 eram de 27:504\$000, tivessem aumentado para 131:381\$000 entre 01 de julho de 1877 a 30 de junho de $1878 .{ }^{87}$

O Poder Público assinou vários contratos com distribuição de concessões e privilégios, onde novos empresários se mostraram dispostos a explorar os rendosos serviços urbanos, numa Capital quase desprovida de infraestrutura.

Os três capitalistas, citados, quando da assinatura do contrato, teriam o monopólio da venda de água por um período de 70 anos e isenção nas taxas de importação e de transporte dos materiais hidráulicos, em contrapartida, eram obrigados a construir seis chafarizes públicos onde as águas seriam distribuídas gratuitamente.

Para as condições da época, com um capitalismo ainda incipiente, uma obra de grande vulto, como esta, nas mãos de particulares, exigia a contribuição de outros investidores que se dispusessem a fundar uma empresa, com subscrição de ações. O aumento do capital social era definido por um procedimento estatutário. Em 25 de junho de 1877, com a finalidade de colocar em prática o contrato de 1875, e solucionar a questão do abastecimento, ou seja, 25 anos depois do primeiro projeto, fundou-se a Companhia Cantareira de Águas e Esgotos. ${ }^{88}$

\footnotetext{
${ }^{86}$ JORNAL DIÁRIO DE SÃO PAULO. São Paulo, 15/12/1868, no 992, p.03.

${ }^{87}$ AGUIRRA, João B. C. Vida Orçamentária de São Paulo, durante um século. In Revista do Arquivo Municipal, São Paulo, 1934, vol II p 31.

${ }_{88}$ Antônio Proost Rodovalho comprou a parte da sociedade que pertencia a Macckinson Fox e ao Major Benedito Antônio da Silva. O presidente da Companhia era o Dr Clemente Falcão de Souza Filho (também diretor da Estrada de Ferro Mogiana), e da diretoria faziam parte: o Barão de Três Rios (Joaquim de Souza Aranha) e o Dr Raphael Aguiar Paes de Barros.

O capital da Companhia era de 2.200:000\$000, divididos em 11.000 ações no valor de $200 \$ 000$ rs cada uma. O capital da empresa era quase a renda total da Província de São Paulo que entre 1876 e 1877 chegou a $2.070: 721 \$ 000$ e de 1877 a 1878 a $3.326: 446 \$ 692$. Com quase esta quantia foi fundado em 1887 o Banco Comercial de São Paulo que tinha Capital de 2.000:000\$000 e 10.000 ações, ainda a título de comparação, no mesmo ano foi fundado o Banco da Lavoura com 1.000:000\$000 e 5.000 ações, segundo, PAULA, Eurípides Simões de. A segunda fundação de São
} 


\subsection{Companhia Cantareira}

A empresa, em um de seus primeiros anúncios, divulgava:

(...) Constando água em abundância nas fraldas da serra próxima, para as bandas do norte rumo ao Jaraguá, e dispondo-se a recém-constituída sociedade a captar essa água dispersa, que rola abaixo e vem desaguar, segundo parece, no Rio Tietê, denominemos de COMPANHIA CANTAREIRA, isso porque a água deverá ser primeiramente reunida nos grotões da serra a fim de que, canalizada, seja trazida para a cidade. E como toda captação de qualquer líquido, especialmente a água, se faz em cântaros, a sociedade construirá tantas cantareiras ou reservatórios, quantos necessários ao consumo da população. ${ }^{89}$ (BRITTO, 1999)

No acordo bilateral, firmado ainda em 1875, entre o Governo da Província e a Companhia, esta se obrigou a fazer o abastecimento como segue: "Tomando por centro o largo da Sé seriam pontos da circunferência, para o lado da Luz, a vertente da Cantareira; para o do Arouche, a Capella de Santa Cecília; para o da Consolação o portão da chácara do major Benedicto Antonio da Silva, onde posteriormente foi localizado o Reservatório chamado da Consolação; para o de Santo Amaro, a casa de residência de João Antonio de Borba, na rua de Santo Amaro; para o lado da Liberdade, 300 metros adeante do largo desse nome; para o da Gloria a ponte sobre o rio do Lavapés; para o da Glória, a Ponte do Lavapés; para o da Tabatinguera, a porteira da Estrada de Ferro Ingleza, no ponto em que ainda hoje a estrada atravessa a rua da Moóca, e para o do Braz, a Estação da Estrada de Ferro do Norte". ${ }^{90}$

Paulo; da pequena cidade à grande metrópole de hoje. São Paulo, Revista de História, ano V, o 17, 1954, p.174.

${ }^{89}$ BRITTO, E. São Paulo Tramway Tremembé, Ed. Prancom, São Paulo, 1999, p. 25.

${ }^{90}$ Contrato celebrado entre o Governo da Província e o Coronel Antonio Proost Rodovalho; Major Benedicto Antonio da Silva e o Engenheiro Daniel Mackinson Fox, para o encanamento das águas da Cantareira e sua distribuição pelas ruas e praças desta Capital. 


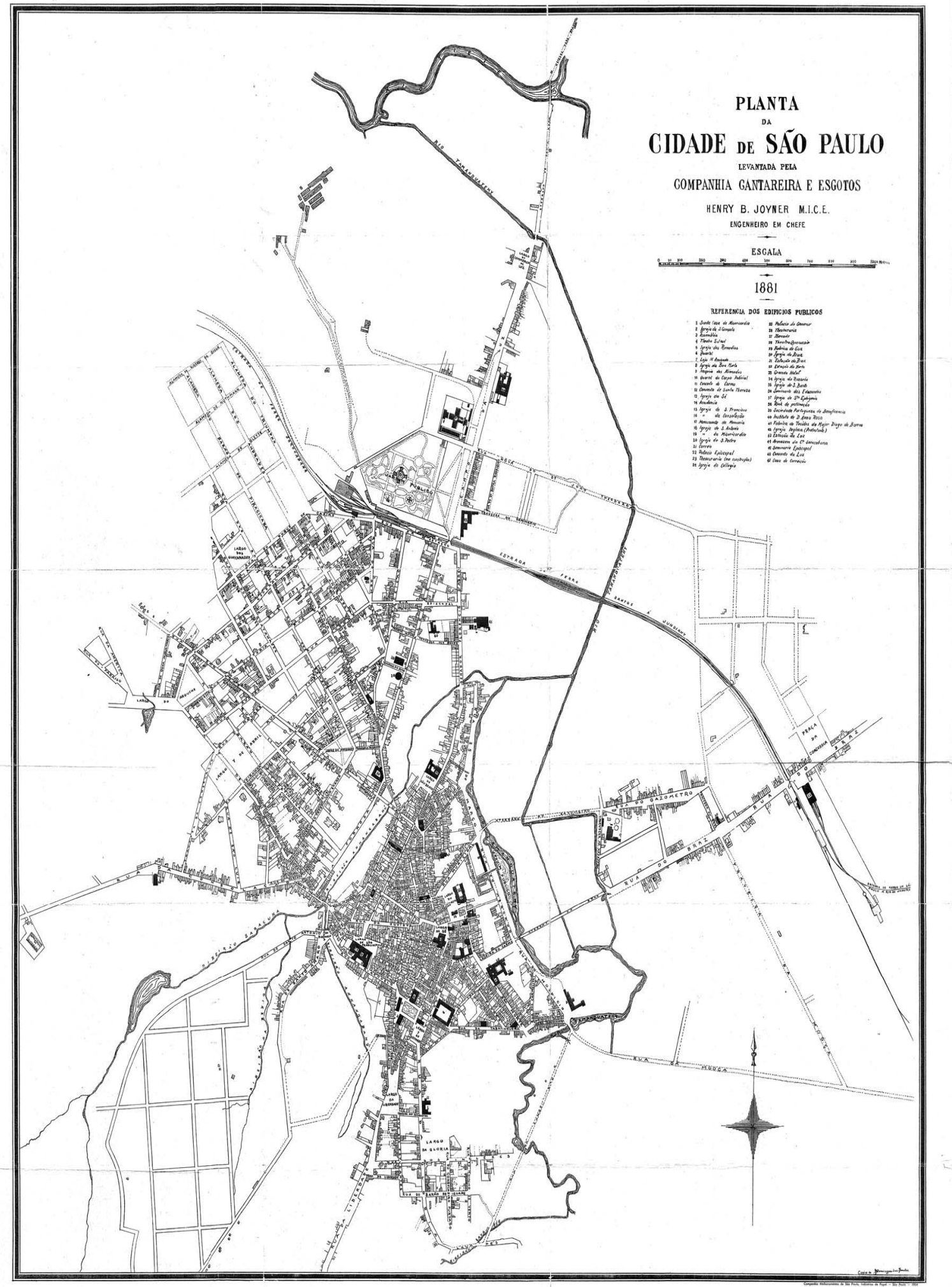

Planta cidade de São Paulo 
Em 5 de novembro de 1878, a Companhia Cantareira contratou o engenheiro inglês Henry Batson Joyner como superintendente técnico para o levantamento da planta-cadastral da Cidade de São Paulo (1881); e para a construção de uma caixa d'água coberta $^{91}$, na Consolação (localizada na então chácara do Capão), inaugurada em 12 de maio de 1881.

Este reservatório, destinado a abastecer diariamente a rede de encanamentos distribuidores, estava dividido em dois compartimentos iguais, de 3.000 metros cúbicos que deviam funcionar um, como reservatório de acumulação, e o outro de distribuição.

Segundo Relatório de 1881, "As muralhas são construídas de alvenaria de tijolo e já se acham levantadas à altura de cerca de $1 \mathrm{~m}, 20 \mathrm{em}$ todo o perímetro da obra. Logo que esteja concluído o serviço de alvenaria, projeta-se revestir a face interna das muralhas com uma camada de asfalto que será applicada em chapas de 0,m127 de espessura sobre 0,m60 de comprimento e $0, \mathrm{~m} 30$ de largura. Actualmente executa-se o revestimento do fundo, sendo espalhada a primeira camada de concreto com a espessura de 0,m30 acima do qual deverá ser lançada uma outra idêntica, e sobre estas ainda duas camadas de asphalto de 0,m127 cada uma, formando-se assim um leito com todas as condições de resistência às accções que está destinado a supportar.

O encanamento abastecedor estende-se desde as presas d'água, na serra da Cantareira, até o reservatório de distribuição na Consolação. Este encanamento apresenta um desenvolvimento de $14 \mathrm{k}, 470$ kilometros. Os canos empregados tem sido revestidos por dentro e por fora com pixe." ${ }^{92}$

"Sendo o diâmetro deste encanamento de $0, \mathrm{~m} 305$, terá elle capacidade para um volume d'água de 3.000 .000 de litros em 24 horas, o que conforma-se exactamente com a capacidade de cada um dos dois compartimentos de que se compõe o reservatório geral de distribuição."93

\footnotetext{
${ }^{91}$ Em 1881 foi considerado como uma das principais obras da Capital, com técnica construtiva nunca vista na cidade, em apenas 13 anos, estava superado, tendo sido destruído para a construção de outro, no mesmo local, pela Repartição de Águas e Esgotos em 1894.

92 SÃ̃ PAULO. Relatório apresentado à Assembléia Legislativa Provincial de São Paulo pelo Presidente da Província Laurindo Abelardo de Brito no dia 13 de janeiro de 1881. Typ. à vapor do Diário de Santos, p. 71,72,73.

${ }^{93}$ SÃO PAULO. Relatório apresentado à Assembléia Legislativa Provincial de São Paulo pelo Presidente da Província Laurindo Abelardo de Brito no dia 13 de janeiro de 1881. Typ. à vapor do Diário de Santos, p.72.
} 
A influência inglesa vai além da participação dos engenheiros na formulação do projeto de abastecimento, e a importação maciça de materiais para a viabilização das obras, vincula aos poucos, a cidade de São Paulo, aos processos internacionais de reprodução de capital.

"A companhia já encomendou todo o seu material na Inglaterra.

Já chegaram 45 toneladas de chumbo para as juntas dos tubos, meia tonelada de estopa para o mesmo fim, 750 barricas de cimento, 3.180 tubos para encanamento com 0,m305 de diâmetro. O peso total de ferro recebido é de 1.137 toneladas". 94

Foi construído um reservatório de acumulação na Serra da Cantareira para onde foram canalizados, além do córrego Barro Branco, os ribeirões Toucinho e Guatemy.

Joyner, desdobrou a rede de distribuição pela zona urbana da cidade, abrangendo a área que se estende da Ponte Grande (onde hoje se localiza a Ponte das Bandeiras) ao Largo da Liberdade, e do meio da encosta da rua da Consolação até a Igreja do Brás, com encanamentos de diâmetros diversos, e uma extensão de 35.660 metros.

"O systema geral dos encanamentos de distribuição, compõe-se de dois ramais principais, partindo dos reservatórios da Consolação: um pela travessa da Consolação, ruas 7 de abril, Aurora, Episcopal e Alegre; e outro pela rua da Consolação, largo da Memória, ruas da Princeza, do Imperador, de Santa Tereza e ladeira do Carmo.

Destes encanamentos partem à esquerda e à direita as ramificações que se estendem por todas as ruas da Cidade.

Os canos que partem dos reservatórios tem 0,m381 de diâmetro e vão progressivamente diminuindo para os districtos mais distantes até 0,m076."95

A implementação da infra-estrutura de captação a partir dos mananciais situados na serra, estava relacionada com a quantidade e a possibilidade de ampliação futura do sistema.

"Calcula-se o volume d'água obtido na Serra da Cantareira em 2.970,07 litros em 24 horas, que distribuído por uma população de 30.870 habitantes,como a que

\footnotetext{
${ }^{94}$ Ibidem, p. 73.

95 SÃO PAULO. Relatório apresentado à Assembléia Legislativa Provincial de São Paulo pelo Presidente da Província Laurindo Abelardo de Brito no dia 13 de janeiro de 1881. Typ. à vapor do Diário de Santos, p.73.
} 
actualmente existe nesta capital, dará a quantidade de 95 litros por habitante e por dia; quantidade esta que ficará muito abaixo dos principaes misteres domésticos, se attender-mos que os especialistas em taes materias marcão como limite mínimo para os usos domésticos e lavagem dos esgotos, 100 litros por pessoa e por dia."96

A dificuldade em conseguir acionistas e ampliar o capital, fez com que a empresa levantasse em Londres, um empréstimo de 1.200:000\$000, contando com apoio do governo.

Nessa época, o Conde de Três Rios, Joaquim de Souza Aranha, era Presidente da Província, e também diretor da Companhia Cantareira, e no relatório provincial explicava:

"Fazendo parte da Diretoria da Companhia tive escrupulos em despachar como Presidente da Província". ${ }^{97}$

Em setembro de 1882, mesmo com algumas críticas quanto à quantidade, a água começou a ser oferecida aos paulistanos; as ruas passaram a ser irrigadas diariamente e as casas e prédios foram ligados à rede distribuidora.

Ainda neste ano, a Companhia reconstruiu alguns chafarizes públicos de fornecimento gratuito de água, conforme exigência contratual, colocando-os nos Largos da Luz, de São Bento, 7 de Setembro (atual Praça Antonio Prado), do Brás, dos Guaianazes (Praça Princesa Isabel) e 7 de Abril (Praça da República).

O abastecimento foi gratuito até março de 1883, quando a Companhia começou a cobrar taxas pelo consumo. A esta altura, existiam 133 prédios abastecidos pela rede geral. Em 1883, o número de ligações já era de 745; em 1884, 1.508; em 1885, 2.776; em 1886, 3.459; em 1887, 4.278 e em 1888, 5.008.

"O preço da água, em 1885, era o seguinte:

- $1^{\text {a }}$ dezena de 1.000 litros mensais, 500rs/1.000 litros;

- $2^{\mathrm{a}}$ dezena de 1.000 litros mensais, 400rs/ 1.000 litros;

- 3a dezena de 1.000 litros mensais, 300rs/ 1.000 litros;

- 4⿳亠丷厂 dezena de 1.000 litros mensais, 200rs/ 1.000 litros;

- $5^{\mathrm{a}}$ e seguintes 150rs/ 1.000 litros."98

\footnotetext{
${ }^{96}$ SÃO PAULO. Relatório apresentado à Assembléia Legislativa Provincial de São Paulo pelo Presidente da Província Laurindo Abelardo de Brito no dia 05 de fevereiro de 1880. Typ. à vapor do Diário de Santos, p.136.

${ }^{97}$ SÃO PAULO. Relatório dirigido à Assembléia Legislativa Provincial de São Paulo pelo 1o VicePresidente da Província Conde de Três Rios e apresentado no acto da instalação da mesma Assembléia pelo $4^{a}$ Vice-Presidente Dr Manoel Marcondes de Moura e Costa, Typgraphia a vapor do Diário de Santos.1882, p.43.
} 
No acordo firmado entre a Companhia e as autoridades governamentais, estimava-se que até o final do século XIX, a população chegaria a 60.000 habitantes, porém em 1892, o censo apontou um crescimento desmesurado, atingindo a 120.000 .

Esse fato, foi fundamental para inviabilizar o cumprimento contratual entre 0 Governo e a Empresa, possuidora de capital limitado para a continuação da empreitada, que exigia mudanças tecnológicas na captação, adução e distribuição. Afinal, a Companhia tinha se proposto a abastecer uma pequena cidade, e não aquela que estava no limiar de tornar-se uma grande metrópole. ${ }^{99}$

Marc Bloch já assinalava que a adoção de determinadas técnicas, não é uma conquista social. Na maioria das vezes a introdução de uma nova técnica é feita através de um grupo ou uma instituição restrita, aprofundando diferenças e acirrando antagonismos. $^{100}$

Em 1892, os empreendedores já haviam adquirido na Serra da Cantareira os terrenos dos mananciais do Cassununga, no intuito de ampliar a captação, porém o Governo resolveu intervir, tomando a seu cargo as obras de adução e encampando a Companhia em 28 de novembro deste ano. Em janeiro de 1893, foi criada a Repartição Técnica de Águas e Esgotos, transferindo-se para a esfera pública os problemas do saneamento urbano.

O Poder Público substituiu os antigos encanamentos da Cia. Cantareira por outros de diâmetro maior e remodelou a Caixa d'água da Consolação, ampliando assim, sua capacidade de armazenamento.

A partir dessa data, as autoridades constituídas, desapropriaram aproximadamente 5.000 hectares na Serra da Cantareira, para construção dos reservatórios da Cuca, Canivete, Manino, Olaria, Itaguassu, Bispo e Guarau ${ }^{101}$.

\footnotetext{
98 JORGE, Clóvis de Athayde. Consolação uma reportagem histórica, Departamento do Patrimônio Histórico. Divisão do Arquivo histórico, Divisão Gráfica Municipal, São Paulo, s/data, pp 98,99.

99 A Companhia já alertava ainda em 1880, "Calculada a quantidade d'água no reservatório de distribuição em 3.000 .000 de litros, dará por cabeça em uma população de 30.000 almas, como a que se computa esta Capital, 100 litros, o que é sufficiente para as necessidades da vida, mas não abundante, e não bastará de futuro." (grifo nosso) in Relatório apresentado à Assembléia Legislativa Provincial de São Paulo pelo Presidente da Província Laurindo Abelardo de Brito no dia 13 de janeiro de 1881. Typ. à vapor do Diário de Santos,1881, p. 73.

100 SILVA, Francisco Carlos Teixeira da. História das Paisagens, in domínios da História - Ensaios de Teoria e Metodologia CARDOSO, Ciro Flamarion org. São Paulo, Editora Campus, 1997, p. 214.

101 SÃO PAULO. Leis, Decretos. Decreto no 195 de 18 de agosto de 1893. Declara de utilidade publica, para desapropriação, os terrenos do sítio Campo Redondo, na Serra da Cantareira, pertencentes a Antonio Rodrigues de Almeida, Companhia Territorial e Estanislau José de Oliveira Queiroz, precisos para as obras de desenvolvimento do abastecimento de água à capital.
} 
Decreto № 177, de 19 de Maio de 1893, relativo a um terreno pertencente à Empresa Industrial de Melhoramentos do Brasil com área de 12.697m2, necessário para a construção de um reservatório de distribuição em um dos pontos mais elevados da serra, para a captação do ribeirão do Cassununga e outros da bacia hidrográfica do Guapira;

Decreto № 183 de 28 de Junho de 1893, referente ao sítio Cachoeiro, pertencente a Augusto Giuliano, com área de 507,16 m2 compreendendo as águas do Guapira.

Decreto № 195 de 18 de Agosto de 1893, relativo ao sítio do Campo Redondo, de Antônio Rodrigues de Almeida, da Companhia Territorial e Estanislau José de Oliveira Queiroz, com área total de $2.553,35 \mathrm{~m} 2$, para a reunião das águas da bacia do Guapira às do Cachoeiro e do Cassununga;

Decreto $n^{\circ}$ 214, de 04 de Novembro de 1893, referente aos terrenos pertencentes a José Estanislau de Queiroz (sítio do Miguel), Pedro Antônio Borges (sítio da Pedra Branca), Joaquim Rodrigues dos Santos Sobrinho (sítio Chapada), Gertrudes Maria Penteado, herdeirosPrudente Barbosa, Martinho Barbosa, José Barbosa, Francisco Barbosa e Cândido Barbosa; Seminário Episcopal e Jesuíno Franco de Oliveira, com área total de 14.278, $20 \mathrm{~m}$ para aproveitamento das águas dos córregos do Marmeleiro ou Pedra Branca, Tanque, Guaraú, Bispo, Matheus, Itaguassú e Manino.

SÃO PAULO. Leis, Decretos. Decreto no 214 de 04 de novembro de 1893. Declara de utilidade pública, para serem desapropriados pelo Estado, necessários para o aumento dos mananciais do abastecimento da capital, as águas dos córregos das Sobras, Marmeleiro ou Pedra Branca, Tanque, Guarahú, Bispo, Matheus, Itaguassú e Manino, situados à esquerda dos reservatórios de accumulação, na serra da Cantareira. 


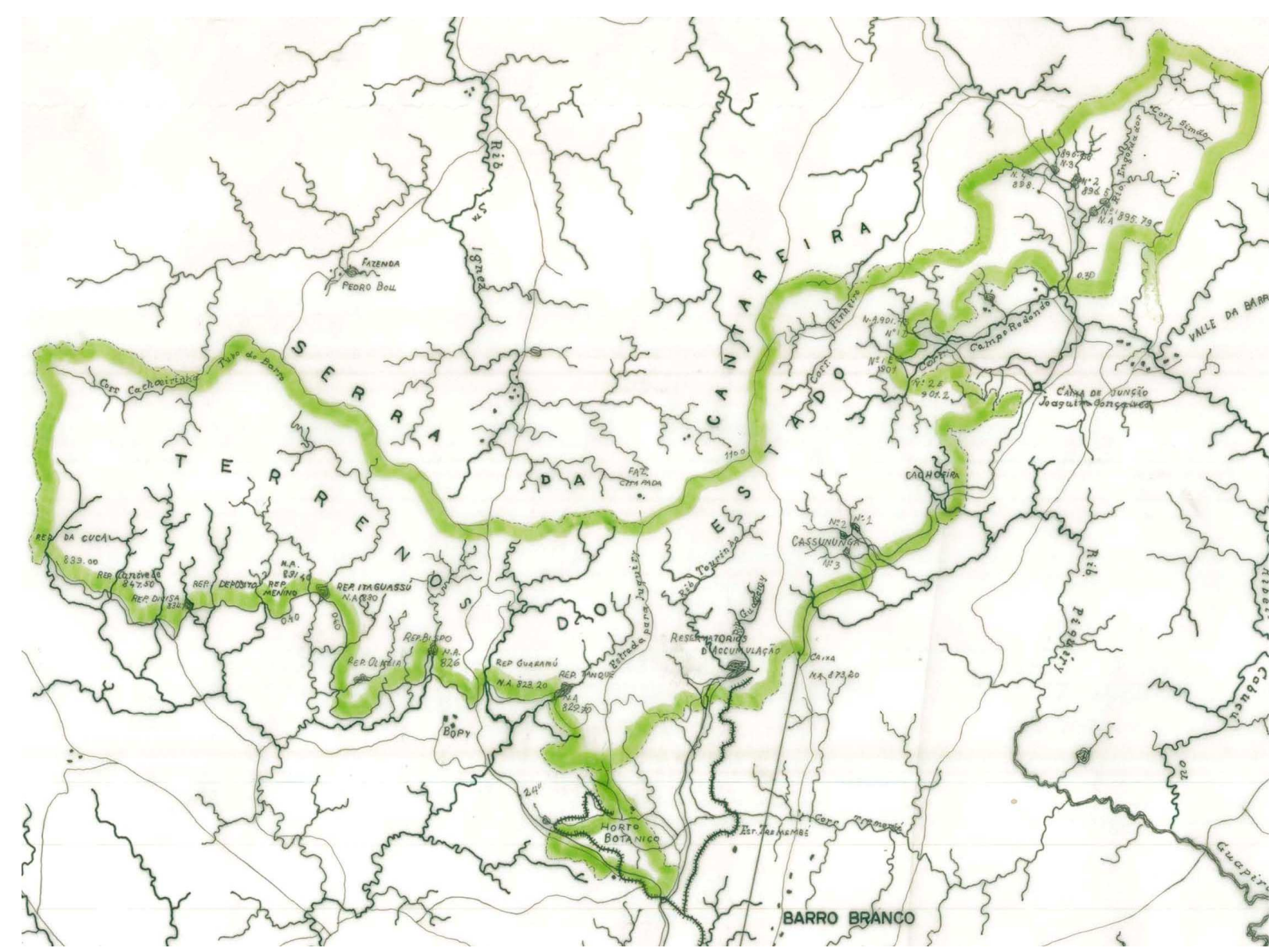

Planta da Cidade de São Paulo dos terrenos desapropriados para o seu abastecimento d'água - Escala 1:50.000 - 1900 - Repartição de Águas e Esgotos (detalhe)

\subsection{A CapitaL do Capital: privado ao estatal}

O arqueólogo industrial ao analisar a cultura material da sociedade industrializada, não pode menosprezar a conjuntura ideológica da época, para não correr o risco de reduzir o seu objeto de estudo a uma sucessão de eventos encadeados de maneira determinista, como se a evolução tecnológica e industrial fosse um resultado previsível.

A encampação da Companhia Cantareira pelo Governo do Estado, e as mudanças operadas pelas autoridades no sistema de abastecimento de água, devem ser compreendidas também no seu contexto social, econômico e ideológico, senão vejamos:

A economia paulistana estava em processo de expansão, alicerçada na produção e comércio do café, e o seu resultado era visível na capital do Estado, com a diversificação das atividades comerciais, criação de instituições bancárias, 
aumento do número de indústrias e o incremento populacional, que evidenciavam as transformações por que passava a cidade.

No plano ideológico, o final do século XIX é marcado pela corrente filosófica do positivismo, que contava com inúmeros adeptos na elite paulistana, que encontraram nessa filosofia uma conciliação entre o liberalismo e o cientificismo, que norteou um esforço para o planejamento social, inspirado no lema "O Amor por princípio e a Ordem por base, o Progresso por fim".

Sob esta ótica, o progresso seria alcançado através de uma planificação que organizasse de maneira lógica e mais funcional a administração pública, conferindo à ciência, nesse desideratum,um papel fundamental.

Como a Monarquia, recém derrubada, era vista como retrógrada, entre outros fatores, devido ao seu centralismo, o novo regime a partir de novembro de 1889 empreende uma descentralização no âmbito federal.

Assim, São Paulo passa a ter a sua própria Constituição, promulgada em 14 de julho de 1891. O agora estado federado, passa a ser governado por um Presidente auxiliado por Secretários de Estado e um Congresso.

Naquele momento, as forças de produção convergiam para uma racionalização da produção cafeeira, uma vez que se delineava no horizonte uma crise mundial no setor.

De acordo com os positivistas, devia haver uma ordem lógica na hierarquia dos órgãos estaduais, assim a secretaria que passava a ter o maior poder econômico, e como conseqüência o político, era a que cuidava dos interesses dos cafeicultores, a Secretaria de Agricultura Comércio e Obras Públicas.

O Decreto ํํ 28 de $1^{\circ}$ de março de $1892^{102}$, organiza e o Decreto ํㅡ 58, de 02 de maio de $1892^{103}$, regulamenta a Secretaria da Agricultura, Comércio e Obras Públicas que tinha sob sua responsabilidade os assuntos relativos à agricultura, terras públicas e particulares, serviço cadastral, colonização, núcleos coloniais, imigração, aldeamento e adaptação de índios, jardins e passeios públicos, engenhos centrais, navegação fluvial e marítima, canais, Comissão Geográfica e Geológica, estradas de ferro, caminhos comuns e de rodagem, mineração, comércio, indústria, sistema de pesos e medidas, serviço astronômico e meteorológico, iluminação,

102 SÃO PAULO. Leis, Decretos. Decreto $n^{\circ} 28$ de $1^{\circ}$ de maio de 1892. Dá nova organização a Secretaria da Agricultura, Comércio de Obras Públicas.

${ }_{103}$ SÃO PAULO. Leis, Decretos. Decreto no 58 de 02 de maio de 1892. Regulamenta a Secretaria da Agricultura, Comércio e Obras Públicas e dá outras providências. 
obras públicas, trabalhos hidráulicos, correios e telégrafos e abastecimento de água e esgotos.

Além de sua estrutura formal, teve parte de suas atribuições executadas por repartições que the ficaram anexas e que realizavam serviços específicos, como a Superintendência de Obras Públicas cuja criação em 27 de dezembro de 1889, antecedia a da própria Secretaria. ${ }^{104}$

A Superintendência foi criada a partir da Repartição de Obras, originada da Inspetoria Geral de Obras Públicas de 1868, e sob a direção e inspeção deste órgão, estavam todas as obras públicas, sendo chefiada desde sua fundação, pelo engenheiro José Pereira Rebouças que reclamava da dificuldade no andamento dos serviços devido a "... falta de idoneidade, do abandono e da tendência à fraude na execução das obras que muitas vezes trouxeram a necessidade de rescisão dos contractos." 105

Desde a Proclamação da República, os processos de infra-estrutura e urbanização que incluíam o saneamento, adquiriam uma urgência e importância estratégica, já que se tratava da inserção do Estado de São Paulo, na economia mundial da assim chamada Segunda Revolução Industrial.

O planejamento urbano da cidade de São Paulo não era antecedente e sim consequência do plano político territorial. Nessa perspectiva, a cidade de São Paulo era o centro das atividades econômicas, políticas, administrativas e culturais dessa sociedade. A capital era o espaço de reprodução do capital aí concentrado, por meio da produção do espaço construído (entre outros processos). ${ }^{106}$ (COSTA, 2003)

No entanto, o saneamento básico estava a cargo da Companhia Cantareira de Águas e Esgotos, uma empresa de capital privado, que nem sempre cumpria no prazo as obras acertadas com o Governo e, o mais grave, não se mostrava em

\footnotetext{
104 SIMÕES JÚNIOR, José Geraldo, O Setor de Obras Pública e as origens do urbanismo na Cidade de São Paulo. Tese apresentada como requisito para a obtenção do título de mestre em Administração Pública pela Escola de Administração de Empresas de São Paulo, Fundação Getúlio Vargas, 1990, p. 57.

105 SÃO PAULO. Relatório apresentado ao Dr Presidente do Estado de São Paulo pelo Dr Jorge Tibiriçá, Secretário de Estado dos Negócios da Agricultura, Commercio e Obras Publicas, Typ G Leuzinger, Rio de Janeiro, 1893, p 14.

${ }^{106}$ COSTA, Luiz Augusto Maia. O ideário urbano paulista na virada do século. Rima Ed. São Paulo, 2003, p. 310
} 
condições de realizá-las com a rapidez e com o direcionamento que propugnava a Superintendência.

Em 1877, conforme projeto proposto pela Cia Cantareira seriam captadas as águas dos ribeirões Toucinho, Guatemy e Pedra Branca para um Reservatório de Acumulação, onde seriam enviadas por gravidade para uma caixa d'água situada na Consolação e daí seguiriam para o consumidor final.

Além das águas da Serra, a empresa adquiriu propriedades nas nascentes do rio Ipiranga, e iniciou de maneira precária, a captação destes mananciais para os bairros do Cambuci e da Mooca aproveitando um projeto de 1866:

"Foi-me apresentada uma proposta feita pelo cidadão João Ribeiro dos Santos Camargo, e engenheiro D. M. Fox, para fornecer agua à Capital, conduzindoa dos ribeiros do Cambucy e Ypiranga..."107

A Companhia desde sua fundação, não realizava todas as obras contratadas, e a partir de 1891, a Superintendência intensifica as críticas aos seus serviços, e propõe ao Governo várias providências, para obrigá-la ao cumprimento de seus contratos.

Entre essas medidas, a que representou um verdadeiro golpe de misericórdia, foi a que determinava a suspensão do pagamento da taxa de esgotos, enquanto ela não cumprisse os prazos de entrega destas obras.

Esta, por sua vez, por meio de incessante correspondência oficial e publicação nos jornais, foi obrigada a recorrer à justiça.

A empresa não conseguia honrar os seus compromissos, e a fragilidade do sistema residia, principalmente, no material básico para as construções, que era, em sua quase totalidade, importado e dependente da evolução e aperfeiçoamento que sofresse fora do país, além disso, a Companhia ficava à mercê dos agentes internacionais, do transporte marítimo, das flutuações do câmbio, das tarifas alfandegárias e dos fretes cobrados pela São Paulo Railway que controlava toda exportação e importação que dependesse do Porto de Santos.

Em 30 de Dezembro de 1891, as autoridades foram informadas da existência de um requerimento da Companhia, pleiteando a interferência do governo para que tivesse preferência na descarga, despacho e expedição na Alfândega, Porto de

107 SÃO PAULO. Relatório apresentado a Assembleia Legislativa Provincial de São Paulo na Primeira Sessão da Decima Oitava Legislatura no dia 3 de Fevereiro de 1866, pelo Presidente da Província Dr João da Silva Carrão, Typographia Imparcial, São Paulo, 1866, p. 21. 
Santos e junto a São Paulo Railway dos materiais para os serviços ao seu encargo, justificando o por quê de não ter ainda iniciado as obras acertadas em maio. Como resposta recebeu uma multa de 2:000\$000.

Nos dias 19 e 20 de Janeiro de 1892, a cidade ficou completamente sem água, e uma comissão de engenheiros enviados a Serra da Cantareira, verificou que o reservatório de Acumulação estava com a metade de sua capacidade, uma vez que devido a estiagem, os riachos do Toucinho, Guatemy e Barro Branco estavam fornecendo apenas 1.500.000 litros diários, ou seja, metade do que enviava normalmente. Para remediar a escassez, os técnicos fizeram a proposta de captar o mais rápido possível as águas do Cassununga para o leito do Barro Branco.

Para facilitar as obras a cargo da Companhia, as autoridades desapropriaram alguns terrenos na Serra, na região do Cassununga, e ainda declararam de utilidade pública áreas adjacentes ao ribeirão Ipiranga.

Como a imprensa da época cobrava maior eficiência na questão do saneamento, e reconhecendo a necessidade de aumentar o suprimento de água e de estender a rede de esgotos, o Governo do Estado resolve intervir promulgando o Decreto № 69 de 28 de Maio de 1892, que o autoriza a assinar um contrato provisório com a Companhia Cantareira de Águas e Esgotos, como forma de pressioná-la a executar os serviços mais urgentes:

1. O prolongamento da canalização do rio Ipiranga no intuito de dar maior pressão à rede de encanamentos servida por esse manancial;

2. A canalização do córrego Cassununga para o reservatório de acumulação, na Serra da Cantareira, com a finalidade de evitar que o volume de água recebido no reservatório fosse inferior à capacidade do encanamento mestre;

3. Construção da galeria principal de esgotos de Santa Cecília, Campos Elíseos e Bom Retiro.

Até o final de Agosto as obras não tinham sido executadas; na canalização do Ipiranga, limitaram-se ao levantamento de plantas e nivelamento; nos serviços do Cassununga, além dos trabalhos de reconhecimento, haviam transportado 229 tubos, abriram algumas valas para os canos e construíram uma estrada de serviço que devido a declividade foi abandonada. Na construção das galerias de esgotos dos bairros de Santa Cecília, Bom Retiro e Campos Elíseos tinham realizado apenas 153 metros de alvenaria. 
A crise instalada no Rio de Janeiro com a Revolta da Armada, obrigou as instituições bancárias a limitarem o crédito e a Companhia não consegue empréstimos, ficando em situação crítica. ${ }^{108}$

O jornal Diário Popular, propõe que o governo auxilie a empresa, tomando momentaneamente a seu cargo as obras que precisam ser terminadas, a título de empréstimo, que seria pago assim que a companhia superasse a crise. Dessa maneira o orçamento do governo não ficaria comprometido caso ocorresse a encampação. $^{109}$

As autoridades têm pressa, e o Congresso do Estado, resolve em 17 de Agosto, autorizar o poder Executivo a rescindir o contrato em vigor desde 29 de Novembro de 1890, encampar a Companhia, e mandar executar as obras de abastecimento de águas e desenvolvimento da rede de esgotos.

O Poder Executivo sanciona a Lei № 62 de 17 de Agosto de 1892:

"Artigo 1Fica o governo autorizado a rescindir e declarar de nenhum efeito o contracto celebrado com a Companhia Cantareira de Águas e Esgotos, em data de 29 de Novembro de 1890, em vista da impossibilidade, confirmada pela Companhia, de realizar os das contractadas.

Art. $2^{\circ}$ O governo realizará a encampação do serviço de águas e esgotos, a cargo daquella Companhia, por meio de acordo, arbitramento ou desapropriação judicial, segundo a lei 38 de 13/03/1836.

$\S 1^{\circ} \mathrm{Na}$ hypotese de accôrdo, o governo poderá atingir ao máximo de 6.000.000 $\$ 000$ para pagamento do material e bens da Companhia, tomando a seu cargo a dívida hypothecaria.

$\S 2$

\footnotetext{
${ }^{108}$ Revolta da Armada ocorreu na presidência do Marechal Floriano Peixoto 1891 - 1894 e opôs o Presidente e a Marinha, o conflito que começou na Capital Federal se estendeu pelo território nacional.

Durante o governo de Floriano, há uma ampliação do jacobinismo e antiestrangeirismo. Apesar de tratar-se de um militar, os Rothschilds apóiam a posse de Floriano, pois tinham sido contrários ao golpe de 3 de novembro executado por Deodoro da Fonseca, logo os títulos brasileiros sobem em Londres, mas depois que o governo federal resolveu autorizar a emissão de 100 mil contos destinados ao empréstimo concedido à indústria brasileira, os ingleses forçam a baixa dos títulos brasileiros. Mais grave e radical, porém, são as medidas de Floriano contra os estrangeiros, o que explica em grande parte a desconfiança e conseqüente fuga de capitais: a guerra civil e o jacobinismo militar levam os europeus a desacreditarem o governo Floriano e a boicotarem todas as medidas de ajuda financeira. Quanto aos empréstimos estrangeiros, o inglês por exemplo, só volta a ser feito quando um civil, Prudente de Moraes, retoma as rédeas do governo.In CARONE, Edgar. A República Velha (Instituições e Classes Sociais), São Paulo, Difusão Européia do Livro, 1972, p. 131.

${ }^{109}$ DIÁRIO POPULAR, São Paulo, de 16 de agosto de 1892.
} 
§ 3ํ O governo tomará a seu cargo a dívida hypothecaria da Companhia contrahida em Londres, pela realização dos dous empréstimos, calculando-se o seu valor em moeda nacional, ao câmbio que for determinado pelos árbitros, valor esse que será deduzido do preço arbitrado ao patrimônio da Companhia."

Art. $3^{\circ}$

Art. $4^{\circ}$

Art. $5^{\circ}$

Art. 6으 governo criará repartição especial para a direcção do Serviço de Águas e Esgotos, dando-Ihe a organização que julgar conveniente."110

A aplicação de recursos públicos nos projetos de infra-estrutura e a constatação da ineficiência da empresa em conseguir um cenário desejável em curto prazo geravam debates na imprensa da época.

"A impossibilidade, que se diz confessada pela Companhia as obras, indispensáveis de realizar as obras contratadas não nos parece, entretando absoluta.

Ela se explica pelas notórias dificuldades da Praça, por circunstâncias especiais do momento, independentes e alheias à vontade da Companhia, que assim se vê privada de lançar mão dos recursos compatíveis com os elementos da vida de que dispõe.

Se estes não podem ser contestados; se a crise que atravessamos constitue, de facto, um caso de força maior para o não cumprimento do contracto; se o auxilio por parte do governo, neste caso, encontra cabal justificação e remove todos os embaraços; vejamos se não é ele preferível à medida extrema e mais ou menos violenta da encampação.

Antes de entrarmos na questão, devemos declarar que não somos accionistas da Companhia, nem a ela nos ligam interesses de qualquer natureza, a não ser os do bem público, que lhe são connexos.

(...) A Companhia tem para fiscalizá-la os próprios accionistas, o poder público e neste caso, o povo que seus serviços utiliza; enquanto que uma empresa

\footnotetext{
${ }^{110}$ SÃO PAULO. Actos do Poder Legislativo do Estado, Typ. do Diário Oficial, São Paulo, 1892, pp. 38,39 .
} 
do Estado só poderá ter o clamor dos consumidores ao qual, não raro, se opõe a indifferença , a desattenção do Poder que, entre nós, é o poder."111

Em 03 de Setembro os empreiteiros se recusaram a prosseguir com as obras, que passariam para a esfera de responsabilidade do Governo. A vista dessa manifestação, o responsável pela Companhia, oficiou ao Secretário da Agricultura, pedindo que esta Secretaria assumisse a direção dos trabalhos e, fizesse a medição dos serviços já executados.

Em 13 de Setembro, o presidente da empresa envia ofício ao Secretário da Agricultura comunicando que não podia prosseguir os serviços contratados e solicita que a Superintendência assuma essas obras.

Ainda no mesmo mês, a Companhia é obrigada a remeter boletins diários para a Superintendência, informando como era realizada a limpeza dos reservatórios, a ligação dos encanamentos dos prédios com o das ruas, como e quando se procedia à lavagem dos esgotos, o tempo decorrido entre os pedidos de desobstrução, e detalhes do funcionamento dos hidrômetros que geravam constantes reclamações e críticas por parte dos usuários.

O impasse aumentou quando a empresa comunicou que não entregaria nenhum boletim diário, e, que desconsiderava qualquer ato do governo que fosse visto como ingerência nos seus negócios enquanto não fosse definida a forma da encampação.

O recrudescimento da falta de água e o evidente desequilíbrio de poder entre os interesses em conflito, tornaram explícita a defasagem entre a natureza dos problemas e os instrumentos institucionais. A estrutura da administração pública precisava de reformas urgentes, capazes de incorporar as demandas sociais pela maior distribuição de água encanada.

É neste momento, que se começa a escrever o enredo da modernização da Superintendência de Obras Públicas, que resultaria na criação da Repartição Técnica de Águas e Esgotos, posteriormente reorganizada como Repartição de Águas e Esgotos, em substituição à Companhia Cantareira.

111 DIÁRIO POPULAR. São Paulo, Questões de Actualidade. Saneamento de S. Paulo, Capítulo X, Companhia Cantareira. Pp.35,36, Acervo do Arquivo do Estado, 1892. 


\subsubsection{Repartição de Águas e Esgotos - RAE}

O paradigma emergente será o controle público no gerenciamento dos recursos hídricos, de forma autoritária, com caráter institucional e tecnológico. A constituição da estrutura de planejamento será feita com a participação exclusiva de engenheiros, excluindo qualquer mecanismo democrático de participação dos usuários nas decisões. A complexidade técnica era instrumentalizada para legitimar a ausência do debate público, e simultaneamente manter fechadas as portas do poder decisório técnico e burocrático.

A construção dessa hegemonia, relaciona-se com a história da transformação da água, ainda de forma difusa, em mercadoria valiosa.

A antiga Companhia tinha aceitado construir chafarizes públicos, sem nenhum custo para o Estado fornecendo nesses locais águas gratuitamente, um claro retrocesso, em termos empresariais, ao disposto na Lei ㄲo 72 de 20 de maio de 1866, (revogada pela Lei 102 de 30 de abril de 1870), que autorizava a Câmara Municipal a comprar e pagar por essa água. Outro detalhe comprometedor para suas finanças, era o fato de que somente o governo poderia estabelecer o valor a ser cobrado dos particulares, envolvendo constantemente a empresa em negociações desgastantes com as autoridades, o que muitas vezes a impedia de repassar os custos da manutenção do sistema aos consumidores.

O longo caminho percorrido entre a captação e a distribuição, faz da água uma mercadoria, um objeto de compra e venda.

Assim como o ar, a água é fundamental para o desenvolvimento e a continuidade da vida, mas ao contrário do ar, a água que consumimos tem preço: afinal ela resulta do trabalho humano.

No momento em que a RAE, tem legalmente o monopólio do aproveitamento das águas, uma de suas primeiras medidas será a destruição desses mesmos chafarizes, acabando com a noção de águas livres e gratuitas para a população; pelo menos os custos das obras de infra-estrutura teriam que ser democratizados.

A cidade em ritmo acelerado de transformação e modernidade não podia esperar, e finalmente a 11 de Outubro, foi assinado o termo de compromisso lavrado entre o Governo do Estado e a Companhia Cantareira de Águas e Esgotos, para arbitrar o valor da indenização que teria que ser pago à Empresa, pela encampação 
de seus serviços e direitos. Um mês depois, para o ajuste definitivo, os peritos estabeleceram o valor: 6,814:549\$663. Embora a indenização fosse maior do que a estipulada na Lei nº 62/1892, foi aceita pelo governo.

A falta de acesso da população à informação, encarada pelos técnicos da RAE, dentro de uma visão de racionalidade científica e tecnológica, e portanto elitista, impediu que a sociedade tivesse acesso aos parâmetros que nortearam a distribuição de água. Afinal, quais os reais motivos de se preocuparem com o fornecimento de água da Cantareira para a Zona Alta, Vila Mariana, região citada como de pouca densidade populacional, em detrimento da Zona Baixa, Brás, Belenzinho e arrabaldes, com demanda sempre crescente?

O antigo modelo de gestão ficava restrito à esfera técnica, despolitizando a opinião pública. Este viés positivista e autoritário das instituições estatais, em que as decisões são tomadas a portas fechadas, abre um precedente perigoso no limiar do próximo século, quando o capital internacional começar a ampliar os seus tentáculos, para os recursos hídricos de economias periféricas como a brasileira.

Apesar disso, os serviços de águas e esgotos, sob a competência do Poder Público sofreram uma incontestável remodelação, procurando acompanhar o surpreendente crescimento populacional pelo qual São Paulo vinha passando, devido sobretudo à política de imigração subsidiada:

$1872 \ldots \ldots \ldots \ldots \ldots .31 .000$
$1886 \ldots \ldots \ldots \ldots \ldots . .47 .697$
$1890 \ldots \ldots \ldots \ldots \ldots .64 .934$
$1892 \ldots \ldots \ldots \ldots \ldots . .120 .000$
$1900 \ldots \ldots \ldots \ldots \ldots . .239 .934^{112}$

"Em verdade, é fundamental o cruzamento dos dados de população com a tecnologia disponível pelo grupo social para se estabelecer se há, ou não, uma relação positiva com a produção necessária de bens." ${ }^{\text {"113 }}$

Quando em 1882, a Cantareira começou o fornecimento, tínhamos 3.000.000 de litros para 30.870 pessoas com média diária de 95 litros. Em 1892, ano de sua encampação, a cidade atingia 120.000 habitantes e a quantidade de água distribuída

\footnotetext{
112 MATOS, Odilon Nogueira. São Paulo no século XIX in A cidade de São Paulo - Estudos de Geografia urbana, Cia Editora Nacional, São Paulo, [19--], p.82.

${ }_{113}$ SILVA, Francisco Carlos Teixeira da. História das Paisagens, in domínios da História - Ensaios de Teoria e Metodologia CARDOSO, Ciro Flamarion org. São Paulo, Editora Campus, 1997, p.215.
} 
permanecia a mesma, com 25 litros per capta, o que tornava a situação desesperadora.

No ano de sua encampação, a empresa conseguia suprir 8.102 prédios, de um total de 17.348; para isso, contava com o Reservatório de Acumulação da Cantareira para a captação dos Córregos, do Toucinho e do Guatemy, e com a Caixa d’água da Consolação para o sistema de distribuição.

O desenvolvimento industrial e urbano verificado durante o século $\mathrm{XIX}$, e o concomitante crescimento demográfico, são geralmente apontados como as principais razões justificativas da necessidade então formulada de se resolver, de uma forma satisfatória, o abastecimento de água às cidades". ${ }^{114}$ (CORDEIRO, 1993)

\subsection{Mudanças no abastecimento}

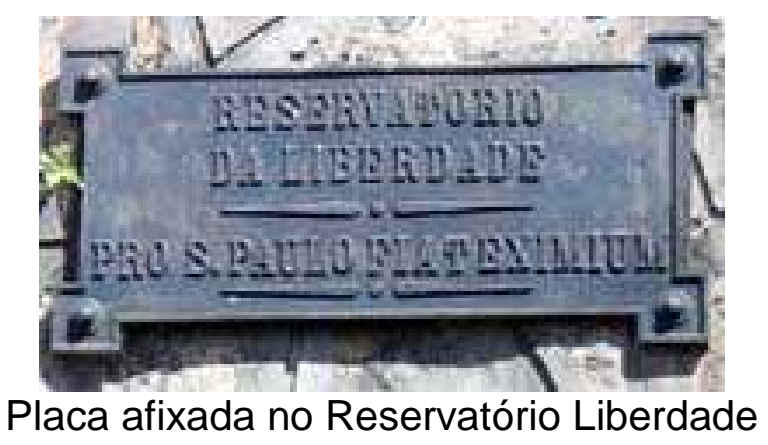

A documentação referente à gestão da água desse período é esparsa e está espalhada por vários órgãos estaduais. Foram necessárias "escavações" nesses documentos para que se obtivessem respostas a questões e a dúvidas que surgiram no decorrer da intervenção arqueológica, em si, ao esclarecer o plano de captação e distribuição de água, ou explicar opções tecnológicas, e decisões que a administração da Companhia Cantareira e sua sucessora a Repartição de Águas e Esgotos, no contexto da São Paulo do século XIX, consideravam como as que mais se adequavam à administração das respectivas empresas.

${ }^{114}$ CORDEIRO, José Manoel Lopes Cordeiro, Um serviço centenário: o abastecimento domiciliário de água à cidade do Porto (1887 - 1987), Separata de Arqueologia Industrial II série, Vol. I, no 1/2 1993, p.11. 
A trajetória de implantação do sistema de abastecimento, e do tipo de técnica utilizada pela Companhia Cantareira, suas rotinas decisórias e de construção, criadas a partir dessas opções, influenciaram as novas decisões.

Até 1892, houve pouco questionamento sobre aspectos técnicos ou econômicos, relativas a essas obras. Não havia o que se discutir porque, pode-se dizer, que até a fundação da Cantareira, esses modernos melhoramentos, eram desconhecidos quase que por completo.

Forçaram a discussão desses problemas, os erros e defeitos que foram aparecendo nos resultados negativos da distribuição, quando houve necessidade de ampliação do sistema, bem como a situação pré-falimentar da empresa que inviabilizava quaisquer investimentos no setor.

Os planejadores urbanos do século XIX responderam a uma demanda de melhoramentos sanitários e estéticos, dentro de um ambiente político e econômico em transformação do qual fizeram parte. Houve incremento de investimentos urbanos relacionados ao desenvolvimento tecnológico da infra-estruturação, dentro de um mercado de capitais mais sofisticado e institucionalizado, em que a maximização do lucro e a atuação dos governos resultaram em grandes investimentos. ${ }^{115}$ (BERNARDINI, 2005)

Para o Poder Público, foi necessário um planejamento que buscasse conciliar um roteiro de intervenções com ações emergenciais e mais abrangentes, mudando um cenário tendencioso, para outro mais desejável e imparcial.

Segundo Dror, planejamento "é o processo que consiste em preparar um conjunto de decisões tendo em vista agir, posteriormente, para atingir determinados objetivos". ${ }^{116}$

O plano para viabiliza-lo é um documento que se materializa em textos, e, também, possibilita sua materialização em termos de ações.

Nesse contexto, o novo ordenamento exigiria uma lógica de investimentos em larga escala, na tentativa de superar as dificuldades técnicas de transformação do sistema implantado pela Companhia Cantareira, que em apenas 15 anos, estava obsoleto e saturado.

\footnotetext{
${ }^{115}$ BERNARDINI, Sydney P. O engenheiro Estevan A. Fuertes e seu plano sanitário para Santos (1892 - 1895) in GITAHY (org) Desenhando a Cidade do Século XIX, São Paulo, editora Rima, 2005,

${ }_{116}$ DROR, V. In ANDERSON, C.A. Le contexte social de la planificacion de l'education. Paris, UNESCO, 1968, p. 10.
} 
A partir do processo de encampação, com os debates na imprensa, a equipe de engenharia da Superintendência de Obras Públicas, em consenso, toma algumas medidas preliminares: conseguir imediatamente encanamentos que estivessem a disposição em outras repartições; melhorar o sistema de transporte com a construção de uma linha de tramway ao custo de Rs. 382:611 \$900, entre a Capital e a Serra da Cantareira, para levar os materiais destinados às obras de abastecimento de água, acabando com outro entrave que era o carregamento em carros de boi e carroças puxadas por burros.

Procede a abertura de uma estrada, para facilitar o transporte dos equipamentos e para estender os encanamentos, ampliando assim a captação do rio Ipiranga e um dos seus afluentes, na tentativa de aumentar a pressão na parte baixa da cidade que fosse abastecida por esse manancial.

Nessas nascentes, a Superintendência encontrou em dias normais, um volume de 5.200.000 litros em 24 horas, enquanto sua antecessora declarava apenas 4.000.000, no entanto, quando resolveram empregar encanamentos de 300mm acabaram comprometendo a distribuição nos mesmos 4.000 .000 de litros.

Os materiais foram adquiridos da Empresa de Obras Públicas da Capital Federal e tinham sido importados para o abastecimento da cidade de Niterói. Pagos pelo câmbio do dia, tinham a vantagem da isenção das taxas alfandegárias, uma vez que se tratava de aquisição para um órgão público.

O transporte foi feito dentro dos padrões de excelência para a época. Para evitar a fratura dos tubos de ferro fundido decidiu-se que a estiva, a bordo dos navios Formica, Akerhnjelm e Godeffroy fosse feita com carvão de pedra, comprado no Rio de Janeiro e vendido para a Zerrenner Bülow \& Cia, fornecedora de materiais para o Governo do Estado, assim que desembarcassem os encanamentos no porto de Santos. 


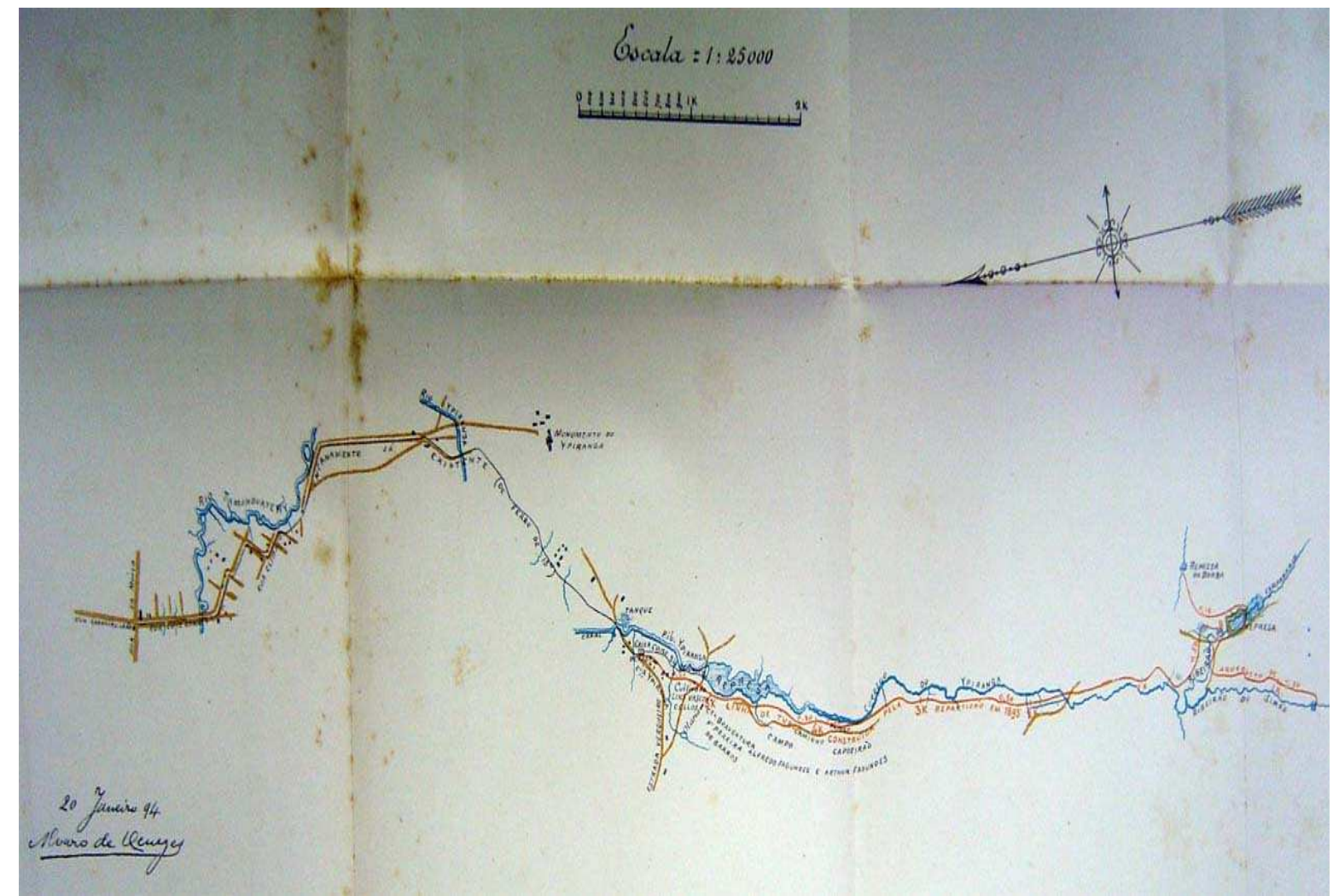

Planta Geral do Encanamento do Ypiranga Indicando a linha de tubos existente e os serviços feitos pela Repartição durante o anno de 1895

Com relação aos esgotos, a R.A.E amplia a galeria principal em $3.300 \mathrm{~m}$ de extensão, sendo os primeiros 580 metros de forma circular, com $800 \mathrm{~mm}$ de diâmetro e o restante em forma ovóide, idêntica aos esgotos de Paris, com 1,70m de altura. No trecho em forma circular foram usados tijolos cuneiformes fabricados pela Companhia Melhoramentos de São Paulo, e na seção ovóide, devido ao ritmo acelerado que os empreiteiros imprimiram aos trabalhos, foram usados tijolos de outros fabricantes.

Devido à urgência na captação do Cassununga e em sua canalização para o vale do Barro Branco, e não havendo disponibilidade de canos de ferro, foi construído um aqueduto com 500mm de diâmetro constituído na parte inferior de uma camada de concreto, e antes mesmo da conclusão da parte superior (que seria em arco de alvenaria com o uso de tijolos), as águas chegaram ao Reservatório de Acumulação, e daí seguiram até a Caixa da Consolação em encanamentos $600 \mathrm{~mm}$.

Aproveitando o volume destes mananciais, foi proposta outra canalização que não servisse ao Reservatório de Acumulação, mas que trouxesse a água direto para a cidade. Os estudos demonstraram que seriam necessários vinte quilômetros de 
encanamentos, porém, as condições ainda precárias de transporte, uma vez que ainda não havia sido implantado o tramway, levaram à aquisição dos tubos da tubos da Mannesmann com 300 mm de diâmetro. ${ }^{117}$

A Superintendência de Obras Públicas, assinou contrato com o agente da Fábrica Deutcsh Mannesmann-Röhren Wek de Berlim, para o fornecimento de vinte quilômetros ou 784 toneladas (comprimento variando entre $3,50 \mathrm{~m}$ e $5 \mathrm{~m}$ ), de tubos de aço superior, fabricados pelo processo Mannesman, tendo um diâmetro interno de 300 milímetros, e uma espessura de 5 milímetros, calculando-se o peso médio por metro corrente à razão de $39,2 \mathrm{~kg}$.

Os testes dos tubos foram realizados por instituição de reconhecida competência, aceita pelo governo brasileiro em Berlim. As despesas para esse fim correram por conta dos fabricantes.

Segundo a documentação escrita, com exceção do encanamento comprado da Mannesman e que viria da Alemanha, os materiais hidráulicos para as obras da Serra da Cantareira, foram adquiridos com os negociantes da antiga Companhia Cantareira, Hopkins, Causer \& Hopkins e procediam de Birminghan, Inglaterra. ${ }^{118}$

Os hidrômetros eram da marca Kent's Uniform Positive Water Metter, e seus acessórios e demais equipamentos para a distribuição de água na zona urbana, foram adquiridos da empresa Zerrenner Bülow \& Com., da cidade inglesa de Manchester, que tinha filial no bairro de Santa Ifigênia.

Com relação ao cimento, a quantidade a ser utilizada inviabilizava a sua aquisição nas casas comerciais da cidade. Neste primeiro momento a Superintendência resolveu comprá-lo diretamente dos navios ancorados no Porto de Santos, em barricas de 180 quilos, provenientes de diversos países.

\footnotetext{
117 O uso desse material foi um pioneirismo para a época, a fabricação de tubos de aço sem costura, através da laminação de um bloco maciço tinha sido inventado dois anos antes, em 1890, pelos irmãos Max e Reinhard Mannesmann.

${ }^{118}$ SÃO PAULO. Relatório da Secretaria dos Negócios da Agricultura, Commercio e Obras Publicas do Estado de São Paulo apresentado em 03 de Março de 1895 ao Dr Bernardino de Campos, Presidente do Estado pelo Dr Jorge Tibiriça,Typ Paulista, São Paulo, 1895.
} 


\subsection{A cidade se transforma}

Pelo Decreto $152-A$ de 31 de Janeiro de $1893^{119}$, regulamentado pelo Decreto $\mathrm{n}^{0} 154$ de 08 de Fevereiro de $1893^{120}$, subordinada à Diretoria da Superintendência de Obras Públicas, foi instituída a Repartição dos Serviços Técnicos de Águas e Esgotos, criada com a missão de executar o custeio e o desenvolvimento do abastecimento de águas e da rede de esgotos da Capital, assumidos pelo Estado com a encampação da Companhia Cantareira.

Em 1893, a RAE manda retirar todos os chafarizes da cidade, para obrigar a população a pagar pela água encanada,

O desenvolvimento econômico começa a se impor como política e anseio de uma parcela da sociedade e do Estado, em meio à realidade de uma população crescente, que vai se concentrando no centro urbano.

O Estado procura se preparar para um desenvolvimento que já está ocorrendo, a população se multiplica, fábricas se instalam na cidade e arredores, e as atividades econômicas se diversificam. O problema com relação à água não se limita à multiplicação de seus usos, estendendo-se aos conflitos gerados por políticas que priorizam determinado uso, em detrimento dos demais.

Em Janeiro de 1893, o engenheiro José Pereira Rebouças, ainda contanto apenas com as águas do Reservatório de Acumulação e do Ipiranga, concebe um novo planejamento para a infra-estrutura do abastecimento de água; a cidade de São Paulo é dividida em zonas de distribuição:

Zona Alta: Liberdade, Glória, Cambuci, Bela Vista, Consolação e Higienópolis a serem abastecidos pelo Reservatório da Liberdade em fase de construção.

Zona Média: Largo Municipal e da Sé, Vila Buarque, Luz, Santa Efigénia, Bom Retiro, Santa Cecília, Campo Elíseos, servidos pelo Reservatório da Consolação,

Zona Baixa: Brás, com as águas dos tanques do Ypiranga.

Para solucionar o fornecimento da zona alta os engenheiros realizaram várias medições, em diferentes épocas do ano, organizando um projeto que compreendeu:

1 ํ Construção das represas nos mananciais situados entre o Cassununga e 0 Engordador;

119 SÃO PAULO. Leis, Decretos, Decreto no 152-A de 31 de janeiro de 1893. Cria as Repartições dos serviços de águas e exgottos e da arrecadação das taxas de água da capital.

${ }_{120}$ SÃO PAULO. Leis, Decretos, Decreto no 154 de 08 de Fevereiro de 1893. Cria e organiza a repartição dos serviços technicos de águas e exgottos da capital 
2ํㅡㄹ Canalização destas nascentes até uma caixa de junção (denominada de Guapira)

3ํAssentamento da linha de tubos de $300 \mathrm{~mm}$ entre essa caixa e o reservatório de distribuição da Liberdade, iniciado em 1893;

Ficou definido que, uma vez adotadas as três zonas distintas de distribuição, cada uma delas deveria ser alimentada com mananciais cujas cotas de captação e volumes fornecidos estivessem de acordo com os pontos de maior altura da respectiva zona, ou com as necessidades relativas à sua área e população.

A parte mais alta da cidade abrangia os bairros da Liberdade, Bela Vista, Consolação, Cambuci e Vila Mariana, cujos pontos máximos exigiam o abastecimento com as águas dos ribeirões: Cassununga, Cachoeira, Campo Redondo e Engordador, os de mais elevada captação na Serra da Cantareira e cujo volume total era superior a 8.000 .000 de litros em 24 horas, fornecendo água em abundância, para estes bairros que tinham pouca densidade demográfica.

No final do ano, a distribuição sofreria novas modificações:

Zona Central e Comercial: Bairros do Bom Retiro, Luz, Santa Efigênia, Santa Cecília, Campos Elíseos, Bela Vista e Vila Buarque, servidos pela canalização de $600 \mathrm{~mm}$ e o Reservatório da Consolação;

Zona Alta da Cidade: Começando nas proximidades do Largo da Sé compreendendo os bairros da Liberdade, Glória, Cambuci, Bela Vista, Consolação e Higienópolis, servidos pelo novo Reservatório da Liberdade (ainda em fase de construção) e diretamente pelo encanamento adutor dos córregos do Cassununga, Cachoeira e Campo Redondo.

Bairro do Brás: servido pela canalização do Ipiranga com auxílio das águas da Serra da Cantareira.

Nessas obras foram usados os tubos de $300 \mathrm{~mm}$ fornecidos ao Estado pela firma Zerrebber Bülow \& Company, e os da marca H.C.H. pela Hopkins, Causer \& Hopkins, de Birmingham. ${ }^{121}$

Foram assentados os encanamentos que estiveram a cargo dos empreiteiros, José Tangari e Antônio Galerio que utilizaram 75 trabalhadores. Os serviços de locação da linha de canalização foram efetuados pelos engenheiros João Baptista

121 SÃO PAULO. Relatório da Secretaria dos Negócios da Agricultura, Commercio e Obras Publicas do Estado de São Paulo apresentado em 03 de Março de 1895 ao Dr Bernardino de Campos, Presidente do Estado pelo Dr Jorge Tibiriça,Typ Paulista, São Paulo, 1895, pp 217/218 
Garolfi e César Castiglioli, que também dirigiram o assentamento desde a serra até o rio Tietê. Desse ponto ao reservatório os trabalhos foram executados sob a fiscalização de Manoel da Rosa Martins. O custo médio aproximado por metro foi de Rs $6 \$ 200$, incluindo todas as despesas, porém, o custo subiu para Rs $\$ 10 \$ 000$ o metro linear, devido às dificuldades do trecho de $1.400 \mathrm{~m}$ na várzea do rio Tietê.

Em 12 de Outubro de 1894, as águas chegaram ao Reservatório da Liberdade e no dia 23, aos moradores das zonas altas.

No final desse ano, a cidade contava com o total de 15 quilômetros de canalização projetada, locada e construída com um total de 27.000.000 de litros em 24 horas, e no ano seguinte, 31.200 .000 litros.

Em 1894, tomando como população da Capital, aproximadamente 140.000 habitantes, vê-se que correspondia a cada um destes o suprimento de água disponível de aproximadamente 223 litros por dia, quando três anos antes, a antiga canalização fornecia pouco mais de 23 litros diários por habitante. ${ }^{122}$

A paisagem urbana é transformada pela industrialização e pela submissão dos recursos hídricos aos novos e diferentes usos. Aos poucos, desaparece a memória das bicas e fontes de água, que agora se escondem atrás de canos que levam suas águas às caixas de distribuição; os chafarizes desativados são recolhidos ao depósito municipal, e somem dos estoques e da papelada burocrática; o rio Tamanduateí é retificado e o Anhangabaú, no limiar do novo século é canalizado; o cidadão afasta-se da água como elemento que tem movimento e ritmo naturais.

Concomitantemente com as obras implantadas ao longo da serra, o tramway que transportava os materiais provoca a valorização dos terrenos situados próximos aos seus trilhos, facilitando a ocupação da zona Norte da capital e a conseqüente especulação imobiliária.

No ano de 1896, ocorre, através de um elenco de diplomas legais, uma reorganização marcada pela descentralização dos serviços atinentes a obras, transportes e saneamento. A Repartição Técnica de Águas e Esgotos da Capital passa a denominar-se Repartição de Águas e Esgotos, ficando desvinculada da Superintendência de Obras Públicas.

O Governo resolve classificar as obras públicas em duas categorias:

122 SÃO PAULO. Relatório de 1895 da Secretaria da Agricultura Comércio e Obras Públicas apresentado ao Presidente do Estado de São Paulo, p.165/166. 
1. Ordinárias: as de caráter permanente como construção, reconstrução, reparos, melhoramentos e conservação de estradas, pontes e edifícios estaduais a cargo da Superintendência, a quem também caberia o serviço de passagens de rios em balsas e canoas.

2. Extraordinárias: as de caráter não permanente e que exigiam uma comissão de técnicos especializados para projetá-las, sem vínculo empregatício com o governo. Faziam parte desse processo os serviços de abastecimento de água e esgotos, e demais obras do plano geral de saneamento, a cargo de pessoal comissionado fiscalizado pelo Estado. Uma vez concluídas passavam a categoria de permanentes.

\subsection{Equipamentos de distribuição}

\subsubsection{Torneiras públicas e hidrômetros}

Desde que assumiu a coordenação do sistema de abastecimento de água, a Superintendência mostrava-se contrária aos chafarizes e à distribuição gratuita à população.

Taunay ao descrever uma casa paulistana do início do século XVIII, cita os quintais exíguos com o indefectível e contaminável poço. ${ }^{123}$ Quase na virada do século XIX alguns hábitos ainda permaneciam, mas teriam que se adaptar aos novos tempos.

Em 1893, devido a uma epidemia de cólera mórbus, a Repartição de Higiene proíbe os poços domésticos, mandando assorear os existentes. A medida embora polêmica teve que ser respeitada, e para minimizar o sofrimento daqueles que não podiam pagar pela água encanada, as autoridades provisoriamente colocaram torneiras públicas em alguns pontos da cidade, nos cruzamentos das ruas do Triunfo, Andradas, Santa Efigênia, Rio Branco, Guaianases, Duque de Caxias, General Osório, Gusmões, Vitória e Aurora e na região de Santa Cecília. A mesma providência foi adotada no bairro operário do Brás, nos quarteirões próximos da

\footnotetext{
${ }^{123}$ TAUnAY, A. de E. História da Cidade de São Paulo sob o Império. Vol. VI. São Paulo: Secr. Mun. Cultura, 1977.
} 
Hospedaria dos Imigrantes, onde teriam aparecido os primeiros casos suspeitos da doença.

Para Rebouças, a divisão da cidade em Zonas de abastecimento para racionalizar o sistema de distribuição, só seria possível com o emprego de hidrômetros, "procurando obtê-los dos mais aperfeiçoados e, por escrupulosa observação, conseguir equitativa e liberal cobrança ainda que a preço reduzido"124

Justificava que o Governo Federal teria adotado este equipamento para o Rio de Janeiro, acrescentando que o Congresso Internacional de Higiene reunido em Budapeste, um ano antes, havia sugerido o seu emprego para cidades com grandes consumos de água.

Para São Paulo foram adotados hidrômetros da marca Kent's, tendo sido solicitado que o contrato de fornecimento com os representantes da empresa em Manchester, Inglaterra, fosse prorrogado por mais quatro anos.

"Em terreno acidentado como aquele em que está colocado a cidade de São Paulo, consideramos o uso do hidrômetro elemento precioso e de adoção imprescindível para regular a perfeita distribuição de água.

No decurso de 1893 nos foi dado conhecer, experimentar e importar o Kent's Uniform Absolute Water Meter, em relação ao qual pouco mais há a desejar, indicando com precisão as menores quantidades d'água sob pequena pressão, o que levou a estabelecer-se as novas ligações com esses aparelhos.

Mudados os relógios de velocidade, deixados pela Companhia Cantareira, assentados aparelhos convenientes nas casas em que faltam, que são em grande número, regularizadas suas observações, é de supor que com o volume que é certo poder conseguir-se, o abastecimento d'água desta Capital será rendoso, não pesado ónus para o Estado e animador para outros cometimentos". ${ }^{25}$

Para ele, a estreita correspondência entre volume gasto e conta de água, induziria os consumidores a limitar seu uso estritamente às reais necessidades, e a corrigir os defeitos de instalação, que sempre provocavam através de vazamentos, marcações elevadas de consumo. Dessa forma, o sistema medido contribuiria eficazmente para a redução de fugas e desperdícios, dando oportunidade a que maior número de usuários gozassem do benefício.

${ }^{124}$ SÃO PAULO. Relatório apresentado pela Superintendência de Obras Públicas do Estado de São Paulo em 31 de Março de 1892 ao Dr Alfredo Maia Secretário da Agricultura Comércio e Obras Pública do Estado, 1893, p.213

${ }^{125}$ Ibidem p.213 
A aplicação deste princípio requer que o consumo de água seja medido, que a cobrança seja proporcional à quantidade consumida e que o cálculo dos custos do suprimento de água seja razoavelmente preciso.

Até então, a cidade tinha fornecimento de água sem medição, com as torneiras livres e chafarizes, e o sistema de penas, que limitava o consumo por meio de uma estrutura apropriada.

Os limitadores de vazão eram peças ou dispositivos intercalados, entre o ramal e a instalação predial, e tinham a finalidade de dificultar o livre e excessivo escoamento da água para o interior da habitação, geralmente os cortiços do centro da cidade.

$\mathrm{Na}$ época, esses limitadores, eram chamados "penas de água", peças dotadas de passagens estreitas formando ângulos, capazes de provocar perdas de carga consideráveis e dessa forma restringir a vazão.

Como não havia marcação do volume escoado em qualquer desses dispositivos, e com a agravante que eram facilmente alterados, dificultando a fiscalização, principalmente nos cortiços, a cobrança de taxas não poderia basear-se no volume fornecido, logo, a forma de taxação era sempre irracional, prejudicando todo o sistema.

Com os chafarizes e as torneiras livres não havia restrição alguma ao consumo e nem ao controle da água fornecida. Era precário, e dava margem a perdas enormes.

A obrigatoriedade do uso de hidrômetros em substituição a esses sistemas, gerou protestos entre os consumidores porém, a Superintendência e a Repartição de Águas e Esgotos não recuaram.

O Decreto 233 de 02 de Março de 1894 que instituiu o Código Sanitário, em seu artigo 329 consagrou o emprego dos hidrômetros em todo o Estado.

Atualmente, a utilização sistemática de medidores é uma prática defendida pela moderna técnica de abastecimento de água, que se apóia no princípio de que a cobrança deverá ser feita pela quantidade fornecida, e que pelo menos as despesas de manutenção e operação dos sistemas, sejam cobertas com recursos provenientes da venda de água.

Com essa premissa, o serviço medido, assegurando o registro do volume de água consumido, permite estabelecer um sistema de cobrança proporcional ao consumo. 


\subsubsection{Reservatório da Liberdade ou da Avenida}

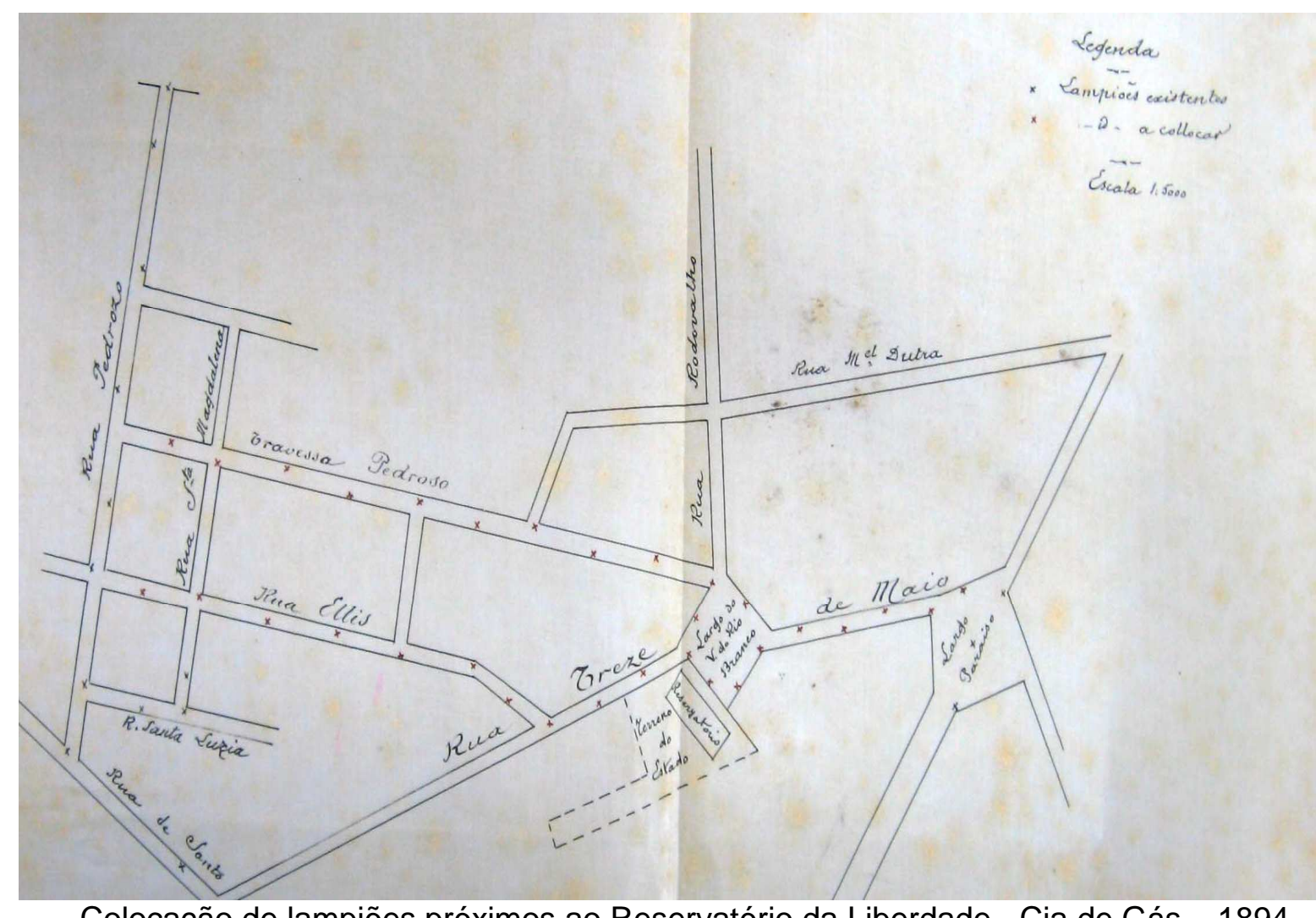

Colocação de lampiões próximos ao Reservatório da Liberdade - Cia de Gás - 1894

Foi inaugurado em 12 de Outubro de 1894, situado em uma área de 12.697 metros quadrados, adquiridos pelo Governo do Estado, da Empresa de Melhoramentos do Brasil ${ }^{126}$.

As fundações dos alicerces das paredes e dos pilares mereceram todo o cuidado, uma vez que, a homogeneidade do terreno, em diversos pontos estava comprometida pela grande quantidade de formigueiros, o que obrigou que a alvenaria de pedra fosse assentada sobre larga e espessa camada de concreto, em profundidade correspondente à consistência do solo.

Tinha capacidade para 6.000 .000 de litros, sendo dividido em duas caixas, concluídas com arcos transversais apoiados em abóbadas longitudinais, de tijolos, com espessura de $450 \mathrm{~mm}$ e revestidas externamente por uma camada de $20 \mathrm{~mm}$ de

${ }^{126}$ SÃO PAULO. Leis e Decretos. Decreto no 177 de 19 de maio de 1893. Declara de utilidade publica, para desapropriação, um terreno pertencente à Empresa Industrial de Melhoramentos no Brazil, afim de nelle ser construído um reservatório de distribuição no ponto mais elevado desta capital. 
cimento e areia, tornando-as estanques. Todo o reservatório foi nivelado com terra, sendo este espaço destinado ao ajardinamento projetado e executado pelos respectivos empreiteiros.

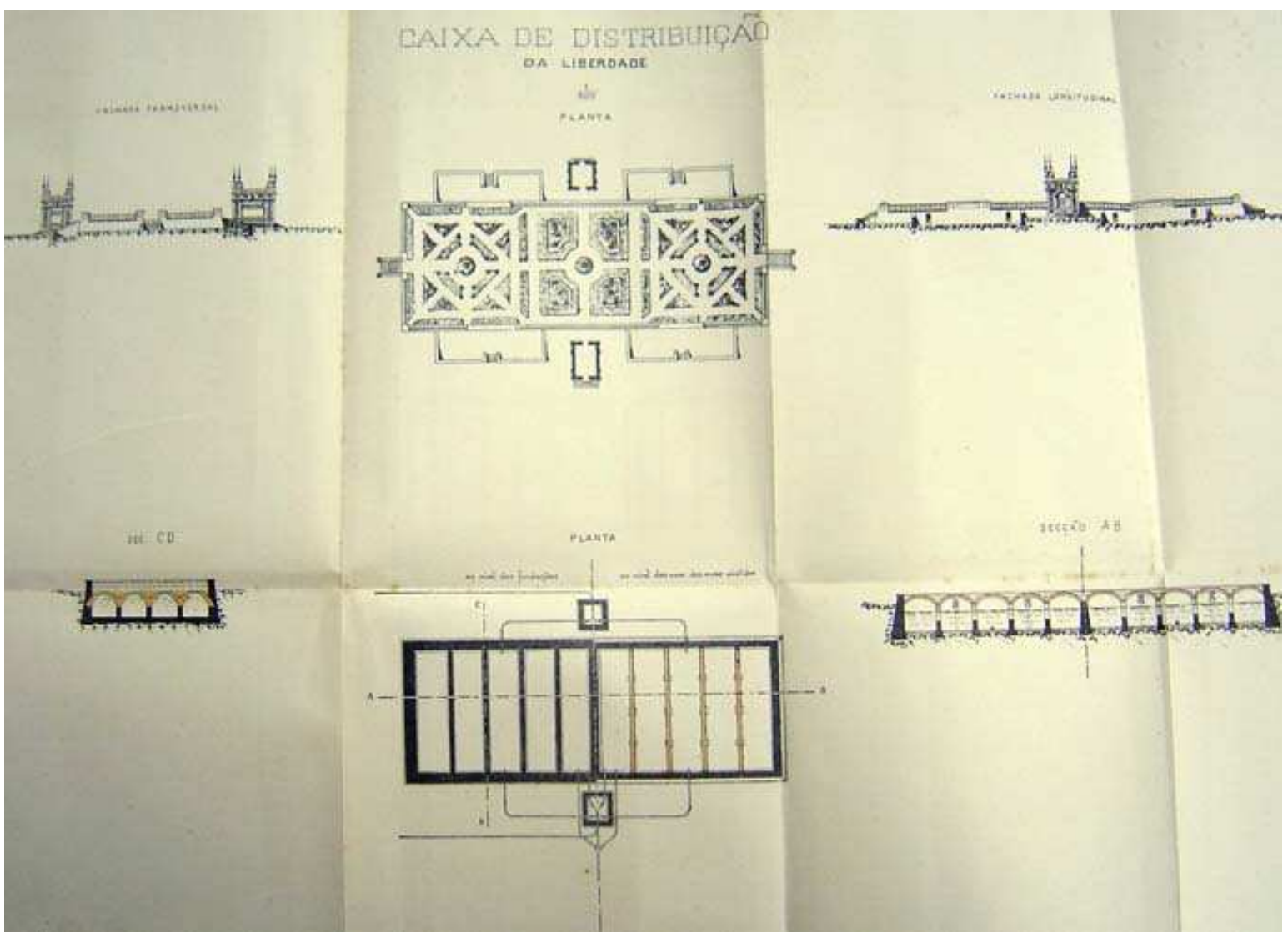

Caixa de Distribuição da Liberdade 1894 Acervo Arquivo do Estado 


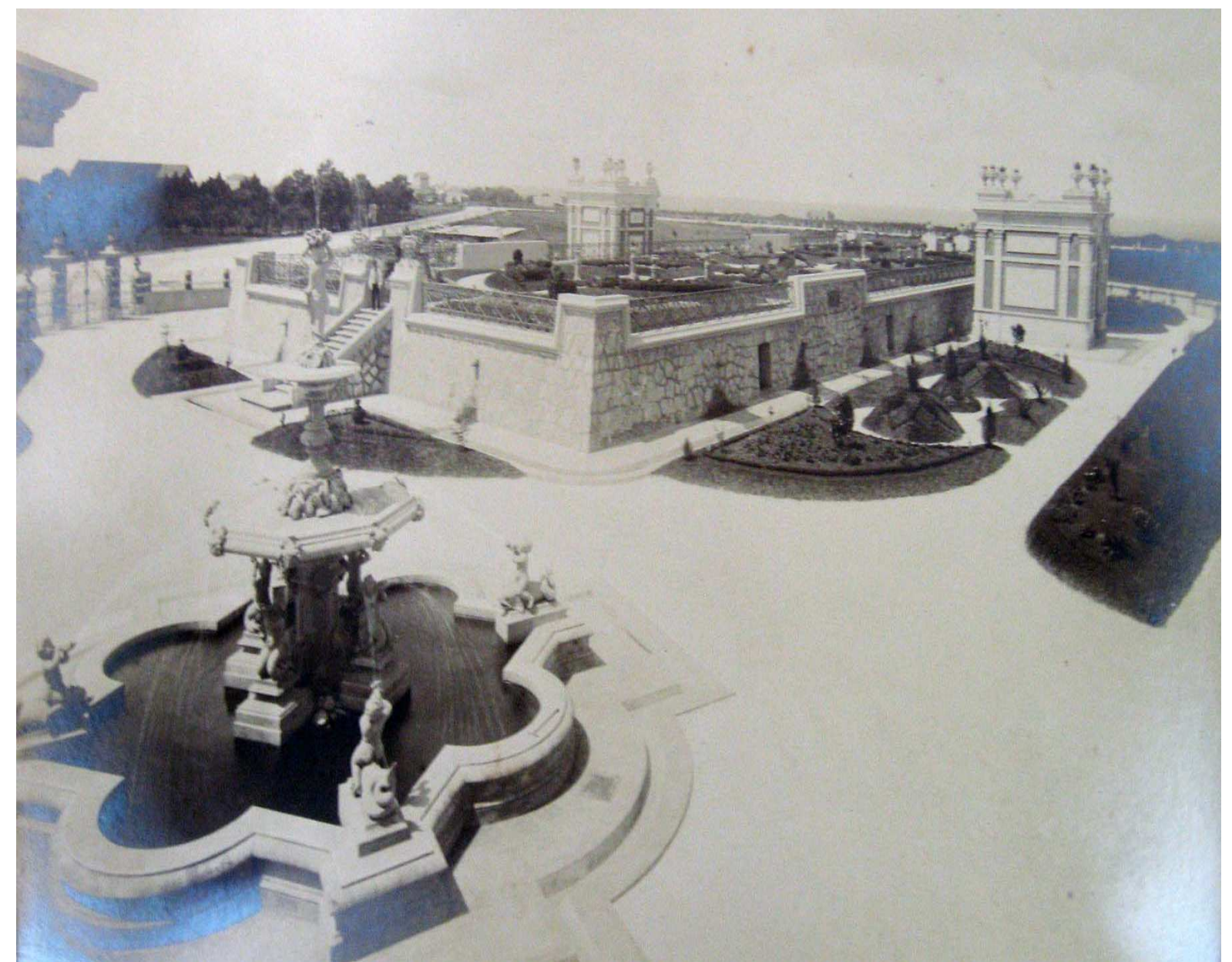

Reservatório da Liberdade Foto P. Doumet 1894 Acervo Escola Politécnica - USP

Para os dois torreões, de manobras de entrada e saída das águas, foram fabricados dois portões de ferro batido pela Companhia Mechanica e Importadora. Com o fim de manter conveniente a aeração nos dois compartimentos, foram construídos seis ventiladores de alvenaria com tijolos a uma altura de 0,40 m.

Recebia as águas dos mananciais do Cassununga e do Engordador depois de passarem pela caixa de junção do Guapira, na Serra da Cantareira. 


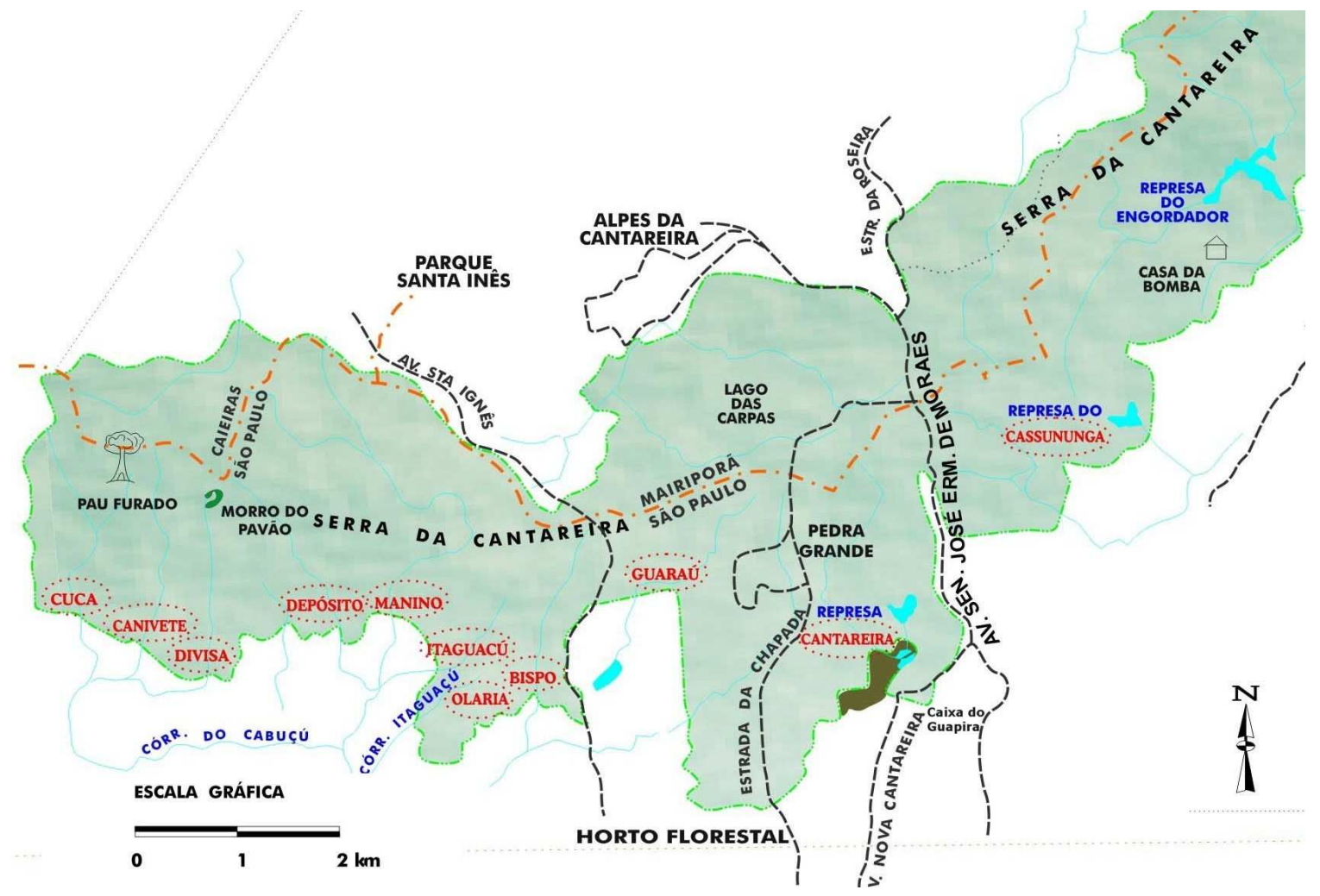

Mapa referente as Represas situadas na Serra da Cantareira

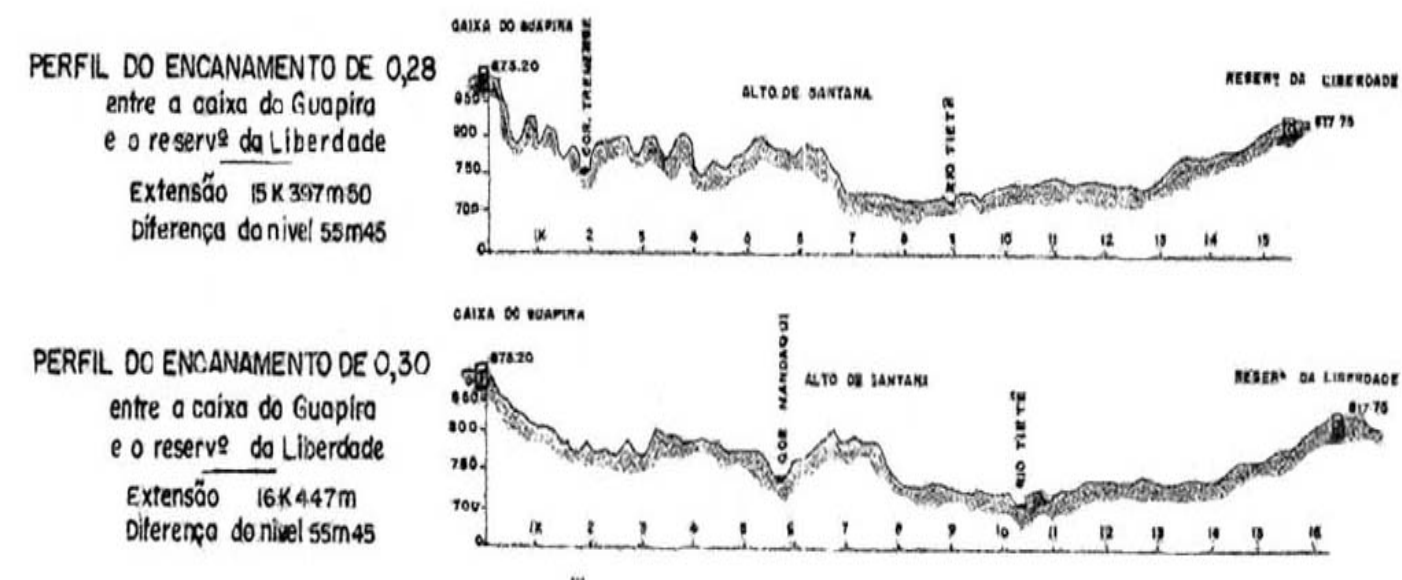

Perfil do encanamento de distribuição

As sobras desse reservatório eram conduzidas para o da Consolação, por um encanamento com 2.300 metros de extensão, e diâmetros de $300 \mathrm{~mm}$ e $200 \mathrm{~mm}$, fornecendo aproximadamente quatro milhões de litros diários, enquanto a zona alta tivesse poucos consumidores. 
A caixa d'água da Consolação era constantemente socorrida pelo Reservatório da Liberdade, devido aos rompimentos dos encanamentos de $600 \mathrm{~mm}$ que vinham da Serra. Implantados em 1892, no auge da crise de encampação da Cantareira, não passaram por testes de capacidade de pressão e devido à urgência, foram mal colocados.

Para minimizar o problema foi reduzido o volume de água neste tipo de canalização, para isso estabeleceram no ponto de ligação de $600 \mathrm{~mm}$ com a rede de distribuição (rua Bento Freitas, esquina com a Major Sertório) um regulador automático, que despejava as águas do encanamento para o coletor principal de esgotos, no vale do Arouche, mas como o equipamento não funcionava muito bem, tiveram que manter no local um funcionário de guarda dia e noite observando um manômetro.

\subsubsection{Reservatório da Consolação}

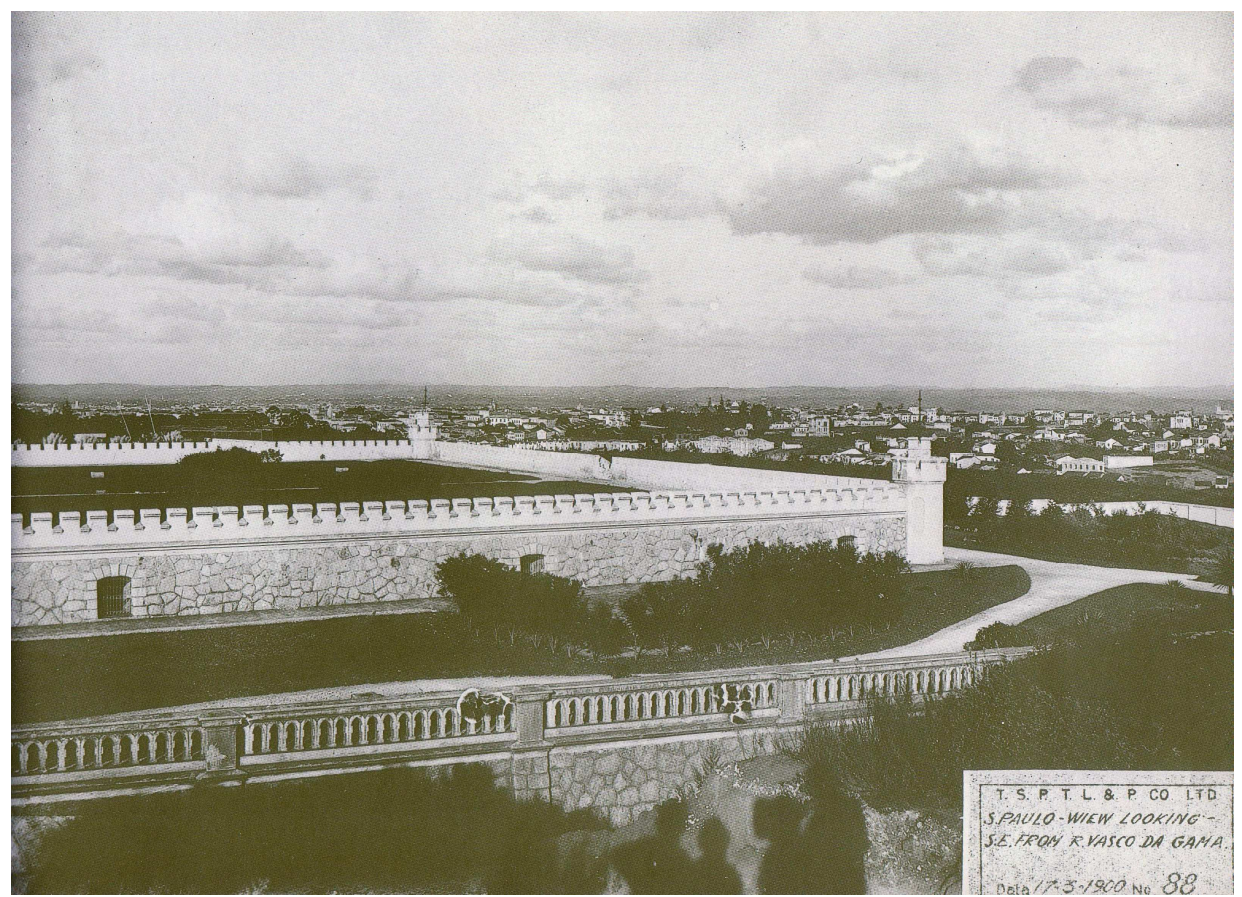

Reservatório da Consolação em 1900 Foto tirada da Rua Vasco da Gama (atual Dona Antônia de Queirós). Ao fundo o Centro da Cidade ${ }^{127}$ 


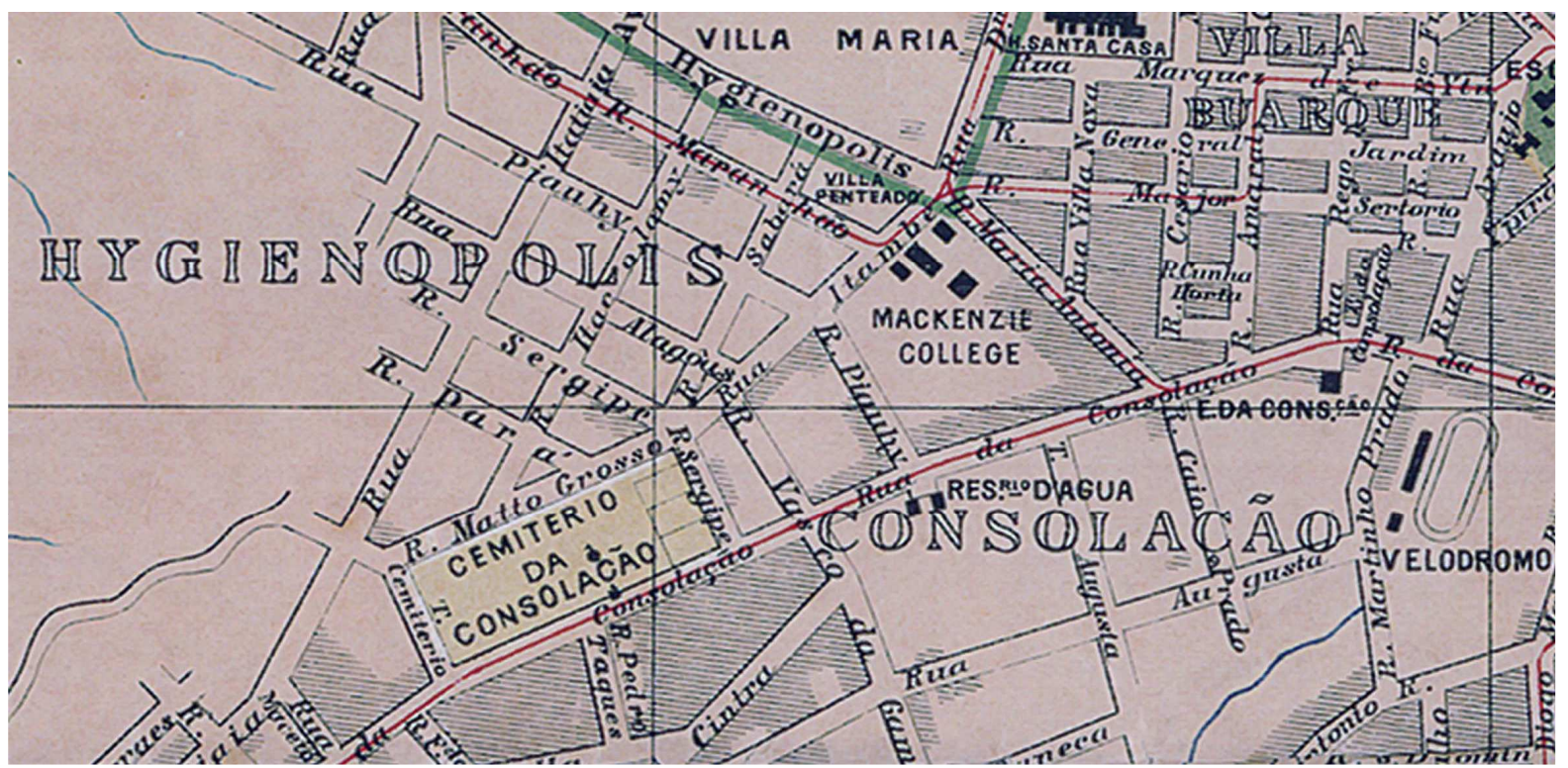

Planta da Cidade de São Paulo Com indicação dos principais edifícios públicos e casas comerciais.(detalhe) . Escala: 1:10.000 - ed. Hugo Bonvicini - 1895

O relatório de 1894, da Repartição Técnica de Abastecimento, alertava que a caixa de água da Consolação inaugurada em 1881, pela antecessora, nunca ficava inteiramente cheia, devido às rachaduras e infiltrações. Mesmo depois das reformas na edificação, no início de 1893, que sanaram esses problemas, continuava sem condições de segurança e estabilidade, tornando imprescindível um outro reservatório, com capacidade de aproximadamente 20.000 .000 de litros, para receber as águas das novas captações na Serra da Cantareira. O Governo acatou a proposta e adquiriu os terrenos do entorno através do Decreto 174 de 06 de maio de $1893^{128}$.

Foram projetadas as obras necessárias para um reservatório com capacidade de 18.000.000 de litros. O orçamento aprovado e que serviu de base à concorrência pública foi o seguinte:

${ }^{128}$ SÃO PAULO. Leis e Decretos, Decreto no 174 de 06 de maio de 1893. Declara de utilidade publica, para desapropriação, um terreno de 14.993,90 metros quadrados, annexo ao actual reservatório da Consolação, pertencente ao cidadão tenente Francisco Augusto de Azevedo, para construcção de novos reservatórios e dependências 
Tabela de Orçamento da Obra

\begin{tabular}{|l|l|l|c|}
\hline $\begin{array}{c}\text { NATUREZA DO } \\
\text { SERVIÇO }\end{array}$ & \multicolumn{1}{|c|}{ VOLUMES } & PREÇOS & TOTAL \\
\hline Movimento de terra & $41.812,680 \mathrm{~m} 3$ & $1 \$ 200$ & $50: 175 \$ 216$ \\
\hline Alvenaria de concreto & $4.875,453 \mathrm{~m} 3$ & $52 \$ 800$ & $257: 423 \$ 917$ \\
\hline " pedra & $8.333,504 \mathrm{~m} 3$ & $48 \$ 000$ & $400: 408 \$ 192$ \\
\hline " tijolos & $3.391,360 \mathrm{~m} 3$ & $55 \$ 000$ & $186: 524 \$ 800$ \\
\hline & & $2 \$ 000$ & $15: 366 \$ 832$ \\
\hline & & & $909: 398 \$ 957^{129}$ \\
\hline
\end{tabular}

Para as obras de alvenaria o cimento seria fornecido pelo Estado.

Dos 33 proponentes ganhou a licitação o engenheiro Urbano de Vasconcellos com a proposta de Rs 773:214\$955.

Em Novembro de 1897, as obras foram concluídas ao custo de $\mathrm{R} \$$ 833.895\$317.

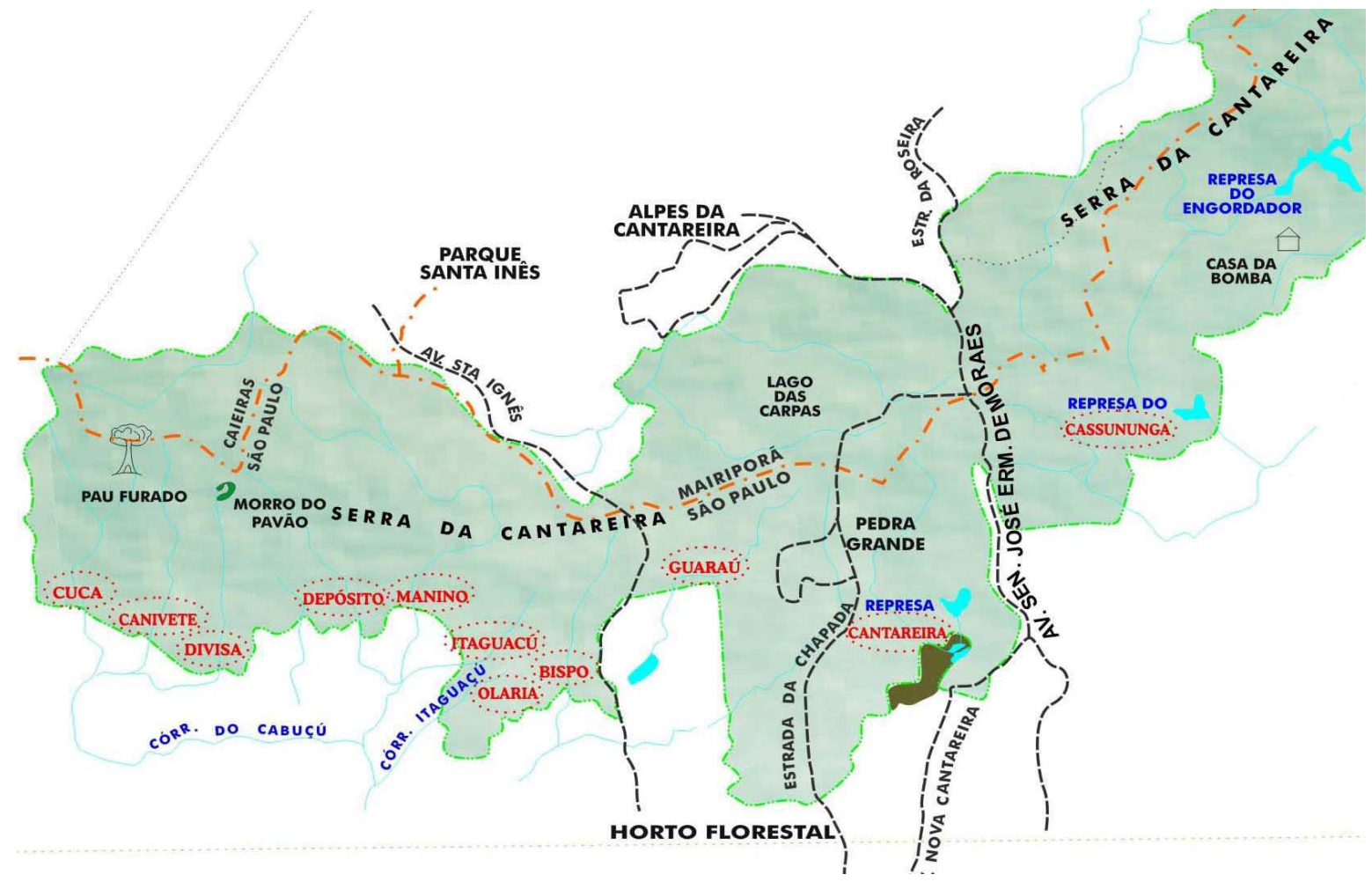

Mapa de localização do Reservatório de Acumulação ou Represa Cantareira

${ }^{129}$ SÃO PAULO. Relatório da Secretaria da Agricultura, 1894, p.231. 
A nova caixa d'água da Consolação, além do Reservatório de Acumulação (Represa da Cantareira), passaria a receber as águas dos riachos da Cuca, Canivete, Divisa, Depósito, Manino, Ytaguassu, Olaria e Bispo que seguiam por aqueduto até o Guaraú, e a partir daí, diretamente ao Reservatório, em encanamentos de $600 \mathrm{~mm}$.

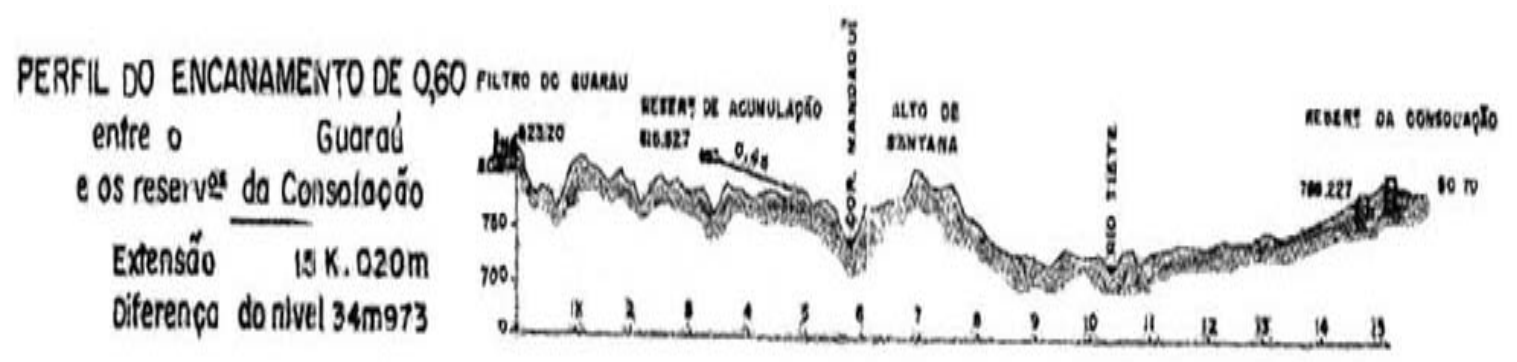

Perfil de distribuição do encanamento de 600mm entre o Guaraú e a Consolação 


\section{NOVA CONFIGURAÇÃO DA VIDA}

No final do século XIX, com a proclamação da República, abre-se para o governo do Estado de São Paulo, uma conjuntura favorável à realização de obras de infra-estrutura, que mudarão o espaço urbano, e que serão fundamentais, não apenas para melhor articular elite paulistana ao mercado internacional, mas também para garantir a inserção do Brasil na "nova" divisão internacional do trabalho, como "parceiro aceitável no rol das nações civilizadas". ${ }^{130}$

Trata-se de um dos períodos mais efervescentes de nossa história, quando se inicia a diversificação da economia nacional, que começava a industrializar-se, e a sociedade em vias de modernização, tinha na indústria seu principal processo de aceleração.

Quando a produção cafeeira paulista atingiu o apogeu, alargando as fronteiras econômicas do Estado, urbanizando transações e negócios, desenvolvendo o transporte ferroviário e atraindo a imigração européia, criou condições propícias para o aparecimento, expansão e montagem de fábricas que até então se diligenciavam, personificadas nos esforços dos pioneiros da época.

Progressivamente, começaram a se delinear, o arcabouço ideológico das indústrias e sua mentalidade civilizatória, na estruturação do novo contexto urbano, alterando a paisagem, em suas coordenadas no tempo, nos móveis e imóveis, como suporte de suas atividades.

A partir da segunda metade do século XIX, as atividades industriais aos poucos passam a compor a paisagem paulistana. Os elementos integrantes do espaço físico condicionaram o aparecimento de certos tipos de infra-estruturas industriais e de serviços, constituindo-se no fator primordial para a escolha dos mananciais da Serra da Cantareira, como fontes de captação de água para o abastecimento da cidade de São Paulo.

Dessas premissas, concluí-se ser, da máxima relevância, a exploração de algumas variáveis, considerando-se que as mesmas diferem, conforme o tipo da atuação industrial que se pretende estudar. No caso da infra-estrutura implantada

\footnotetext{
${ }^{130}$ HARDMAN, Francisco F. Trem Fantasma. A modernidade na selva. São Paulo. Companhia das Letras, 1988, p.16.
} 
pela Companhia Cantareira, e sua sucessora a Repartição de Águas e Esgotos RAE, deve-se levar em conta:

- As mudanças no cotidiano dos paulistanos, com a introdução de um sistema regular de abastecimento de água.

- As relações entre o fenômeno da construção e o do conceito de uma cidade moderna e burguesa, a partir de 1877, com repercussões nos setores produtivos, que poderiam se beneficiar com essas infra-estruturas.

- As alterações provocadas nas redes de transportes, destinadas à entrada e saída de materiais para as obras, que nesse caso levaram à implantação de uma ferrovia urbana conhecida como tramway da Cantareira.

\subsection{A cidade salubre ${ }^{131}$}

O desenvolvimento industrial realizava-se no bojo do complexo agrárioexportador $^{132}$, que propiciou a criação de instituições financeiras e bancárias. A Capital paulistana teve uma filial do Banco do Brasil, somente em 1855, funcionando na Rua Direita, com quatro funcionários; em 1859 fundava-se o Banco de São Paulo, e em 1875 surgia a Caixa Econômica.

No entanto, em 1887, no auge da produção cafeeira, a situação mudou:

- Banco do Brasil com 33.000:000\$000 de capital e 165.000 ações,

- Crédito Real de São Paulo, 5.000:000\$000 e 100.000 ações;

- London and Brazilian Bank, Libras 1.000 .000 e 50 ações;

- English Bank of Rio de Janeiro, com Libras 1.000 .000 e 50.000 ações;

- Banco Comercial de São Paulo, com 2.000:000\$000 e 10.000 ações,

- Banco da Lavoura, com 1.000:000\$000 de capital e 5.000 ações. $^{133}$

O incremento do capital financeiro e industrial, aliado a uma oferta de mão-deobra proporcionada pelo incentivo do Estado à imigração, fez com que também aumentassem as atividades ligadas ao comércio.

\footnotetext{
${ }^{131}$ Termo usado pelo professor Victor da Silva Freire na Conferência realizada em 13 de março de 1914, no Grêmio Politécnico in Revista Polytechnica Typographia Brazil Rothschild \& Co. São Paulo, 1914 p. 219 a p. 254

132 NADAI, Elza. Ideologia do Progresso e Ensino Superior. São Paulo. Ed. Loyola, 1987, p. 94.

133 PAULA, Eurípides Simões de. A segunda fundação de São Paulo; da pequena cidade à grande metrópole de hoje. São Paulo, Revista de História, ano V, no 17, 1954, p176.
} 
Aos poucos, aquele velho panorama de armazéns de secos e molhados, lojas de panos de algodão e hospedarias rústicas, vai sendo transformado pela presença das importadoras, das casas de moda, de vinhos, de materiais de construção, e dos hotéis de porte, a isso correspondendo novas conformações urbanísticas. ${ }^{134}$ (BARBUY, 2006)

No século XIX, a oligarquia cafeeira, inspirada nos ingleses e franceses, teve a perspicácia de confirmar as teorias, segundas as quais, existia uma estreita relação entre os problemas de saúde pública, e as condições físicas do ambiente, que poderiam gerar convulsões sociais, na Capital paulistana que estava se industrializando. Para evitar esses conflitos, que alteram a rotina do sistema produtivo, há uma nova ordenação do espaço urbano, com a promulgação de leis sanitárias e de edificações, principalmente para as habitações populares, procurando acomodar os interesses da nascente burguesia, em detrimento das camadas menos favorecidas da população.

Em São Paulo, o Código Sanitário, Lei no 233 de 02 de Março de 1894, tinha um capítulo dedicado à regulamentação da higiene nas edificações, obrigando os donos dos imóveis de aluguel, a introduzirem itens básicos de salubridade nas construções. Esse instrumento legal, procurava dar ordenamento às questões de saneamento, porém, feria costumes arraigados, desde o período colonial.

Os viajantes do começo do século XIX relatavam as condições das casas paulistanas:

Insetos como mosquitos, baratas, pulgas, bichos-de-pé, entre outros, típicos de países tropicais, estão presentes em muitas descrições associados à sujeira e à falta de cuidados com o lar. ...

... o artifício de queimar ervas aromáticas como a alfazema, trazia às casas um aspecto de limpeza, já que esses odores invadiam 0 ar, e em muitas vezes, despistavam os cheiros desagradáveis. ${ }^{135}$ (SIMÕES, 2001)

Naquela época, o asseio através dos banhos, as necessidades fisiológicas e o destino dos dejetos, eram questões tratadas separadamente. A higiene pessoal era pontual, e efetuada em banhos de rios, ou pela maioria das pessoas nos

\footnotetext{
134 BARBUY, Heloísa. A Cidade-Exposição - Comércio e Cosmopolitismo em São Paulo, 160 - 1915. São Paulo, EDUSP, 2006, p. 28

135 SIMÕES,R. (org) Equipamentos, usos e costumes da casa brasileira, vol. 3. Costumes, Museu da Casa Brasileira.São Paulo, 2001, p.18.
} 
quartos, usando-se bacias de metal ou gamelas de madeira. A importância da água resumia-se principalmente no preparo dos alimentos, e para matar a sede.

"Não é necessário esforço de imaginação para entender como se tomava banho sem água encanada. Basta lembrar uma banhista de Degas, acocorada sobre uma bacia de metal."136

As necessidades fisiológicas se resolviam, na maioria das vezes, no quintal das casas, onde havia a "casinha" ou até mesmo no mato mais próximo. As mulheres utilizavam os urinóis e os pequenos cômodos das latrinas, que muitas vezes eram construídas sobre buracos, que de tempos em tempos, eram esvaziados, levando-se os resíduos para serem jogados nas várzeas do Tamanduateí ou do Tietê.

O banho, ao longo da história, foi quase sempre de imersão, e somente no começo do século XIX surgiu na Europa uma grande novidade, o chuveiro. Para LANDI:

(...) aqui se associam o problema dos costumes com os recursos tecnológicos. As banheiras das famílias abastadas eram construídas em pedra ou mármore. As banheiras populares eram em madeira, seguindo o mesmo princípio dos tonéis. No século passado, estas últimas passaram a receber um revestimento em folha de zinco ou chumbo para melhorar a impermeabilidade. ${ }^{137}$ (LANDI, 1991)

Em 1865, com a inauguração do primeiro estabelecimento de banhos da cidade, o "Serea Paulista", os paulistanos:

(...) se depararam pela primeira vez com chuveiros manuais e com banheiras de zinco, em que se podia tomar banhos de imersão, chegando, os ricos, a encomendar vastas banheiras talhadas em blocos de fino mármore, como é o caso do exemplar que dizem ter pertencido à Marquesa de Santos, hoje exposto na chamada Casa da Marquesa. ${ }^{138}$

\footnotetext{
${ }^{136}$ PERROT, Michelle (org). História da Vida Privada. Da Revolução Francesa à Primeira Guerra. Vol 4, São Paulo, ed Schwarcz, 1991, p. 444.

${ }^{137}$ LANDI, Francisco R. A Evolução histórica das instalações hidráulicas. São Paulo, Boletim Técnico da Escola Politécnica, no 100, 1991, p. 20.

${ }_{138}$ CAMPOS,Eudes, São Paulo: desenvolvimento urbano e arquitetura sob o império, In História da cidade de São Paulo, Paz e Terra, 2004, p. 198.
} 
A partir de 1881, com a água encanada e as dificuldades em adquirir os equipamentos importados para equipar as casas, foi adotado o sistema que poupava o uso de material hidráulico, juntando no mesmo ambiente o banheiro e a "casa de banho". As residências de luxo destinaram-lhe um cômodo exclusivo. As peças apropriadas para esse tipo de ambiente deixaram de ser portáteis, e passaram a ser fixada, e os banhos aos poucos, se tornaram regulares.

A água corrente possibilitava o aperfeiçoamento dos hábitos higiênicos. Ao aumento das possibilidades financeiras dos proprietários mais abastados, correspondia um refinamento técnico, uma integração crescente nos benefícios da civilização industrial e, conseqüentemente, um refinamento de usos, até então desconhecidos. ${ }^{139}$

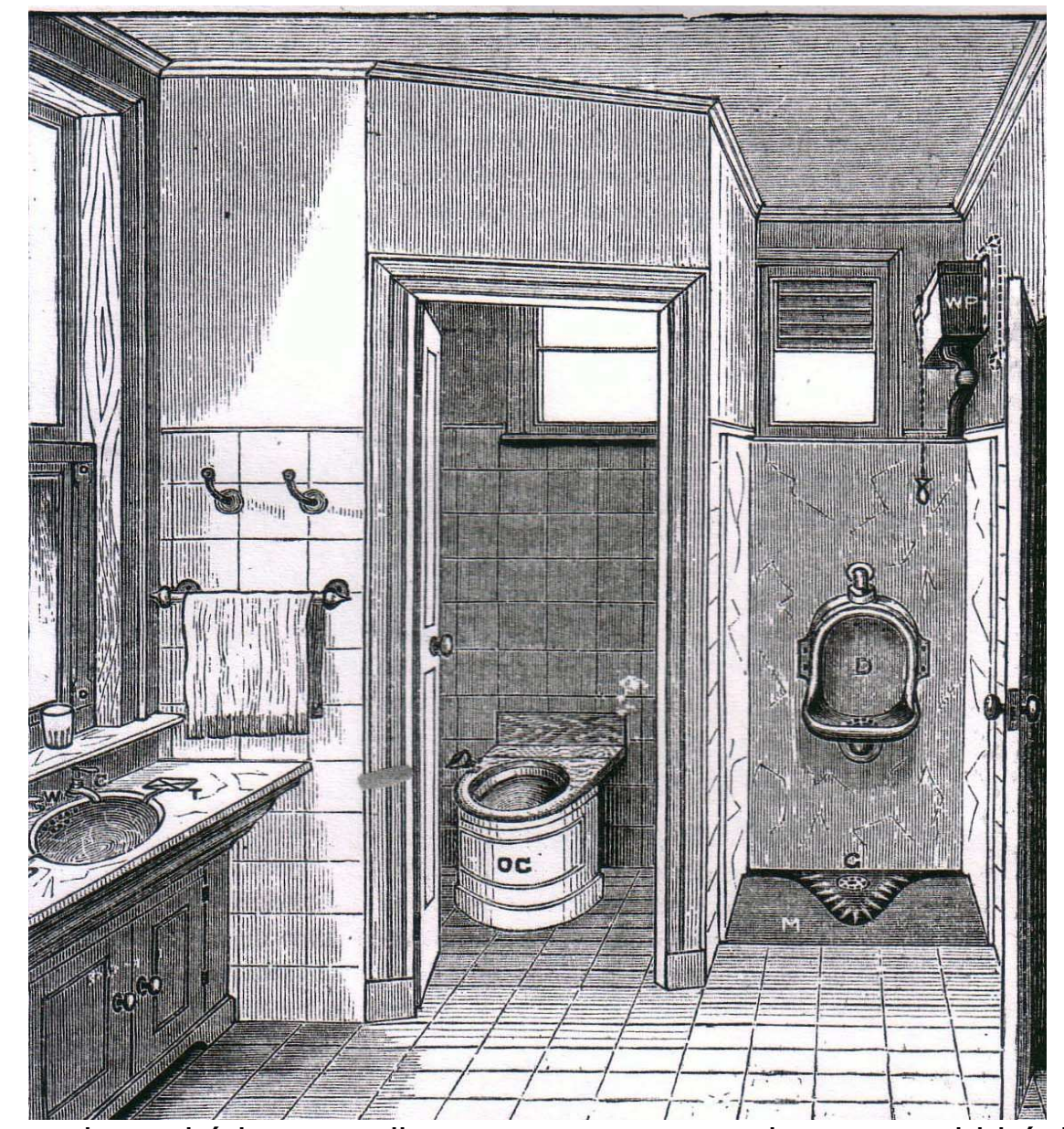

Proposta de sanitário masculino com os novos equipamentos hidráulicos e higiênicos ${ }^{140}$

\footnotetext{
${ }^{139}$ REIS FILHO, N.G. Quadro da Arquitetura no Brasil, Ed Perspectiva,1970, p.50.

${ }^{140}$ POUPARD, Aîné, La Plomberie au Point de vue de La Salubrité des Maison par S. Stevens Hellyer (Traduit de L'Anglais, Paris, Librairie Génélarle de L'Architecture et des Travaux Publics, 1886, p.377.
} 
Nos banheiros dissemina-se o autoclismo inglês, e assim como em algumas cidades européias, a capital paulistana entra na idade de ouro da canalização. As casas situadas nos bairros centrais, passaram a ter água constante e em grande quantidade. Os novos hábitos de higiene teriam que se adaptar aos novos equipamentos, e estes aos novos costumes. Os aparelhos hidráulicos vieram ao encontro da revalorização do asseio pessoal, e de uma nova noção de conforto e salubridade, preconizada pelas teorias sanitárias, que muito tardiamente chegou às classes mais populares.

Com relação à essa população, quem não dispusesse de uma casa de pau-apique, para morar no centro da cidade, era obrigada a se instalar e pagar aluguel em um cortiço, segundo Relatório do Intendente Municipal, esta se constituía em moradia-padrão dos despossuídos, abrigando várias famílias. ${ }^{141}$

Portanto, "o cortiço, a fábrica e a estrada de ferro, constituíram-se nos principais elementos do novo complexo urbano. ${ }^{142}$

As instalações prediais deveriam contar com instalações hidráulicas, e sanitárias, e sua exigência a partir do Código Sanitário, Decreto ํㅡㄹ 233/1894, gerou protestos entre os construtores, e os proprietários de casas de aluguel e de cortiços, que estavam preocupados apenas com os seus lucros, e não com o bem estar de seus locatários.

O Poder Público já havia aplicado outras disposições, como a Lei no 13 de 27 de março de 1886, que determinava em seu artigo $1^{\circ}$ inciso $4^{\circ}$ : "os cortiços deverão ter em todos eles portas e janelas, sendo a largura definida em $90 \mathrm{~cm}$ de largura e $1,80 \mathrm{~m}$ de altura, porém, a situação continuava inalterada". ${ }^{143}$

"O primeiro inquilino pede umas alterações; dividem-se as alcovas porque tem muita família; vão se fazendo melhoramentos; mais contrafeitos para outros inquilinos; mais accomodações; com os annos mais e mais remendos; tudo

\footnotetext{
${ }^{141}$ SÃO PAULO. Relatório apresentado à Câmara Municipal de São Paulo pelo Intendente Municipal Cesário Ramalho da Silva em 1893, São Paulo, 1894, Acervo Biblioteca Mário de Andrade, Setor de Obras Raras.

${ }_{142}$ MUMFORD, L. A Cidade na História, usas origens, transformações e perspectivas. São Paulo, Editora Martins Fontes, 1998, p.496.

${ }^{143}$ SÃO PAULO. Leis e Decretos, Lei ํo 13 de 27 de março de 1886. Dispõe sobre habitações populares e dá outras providências.
} 
baratinho; só o "indispensável” para que dê sempre 8 por cento. A casa fica um agglomerado de gaiolas sem luz, de pardieiros sem ar, sem aceio."144

Um cortiço típico, segundo pesquisa realizada em 1893, ocupava o interior de um quarteirão, onde o terreno era geralmente baixo e úmido, e sua salubridade ficava na dependência dos recursos financeiros de seu proprietário.

Era formado por uma série de pequenas moradias em torno de um pátio exíguo ao qual vinha ter, da rua, um corredor longo e estreito. A moradia média abrigava de 4 a 6 pessoas, embora suas dimensões raramente excedessem 3 metros por 5 ou 6 , com uma altura de 3 a 3,5 metros. Os móveis existentes ocupavam um terço do espaço. $O$ cubículo de dormir não tinha luz nem ventilação; superlotado, à noite era "hermeticamente fechado". Exceto nos cômodos de pessoas naturais do norte da Europa, o soalho ficava tão incrustado de lama, que não se viam as tábuas; a umidade do solo onde elas repousavam fazia descascar o papel ordinário e liso das paredes. Estes e os tetos eram pretos de sujeira de moscas e da fumaça do fogão que a chaminé mal feita e mal conservada não eliminava convenientemente.

$O$ pátio principal fornecia às moradias que o rodeavam uma torneira recalcitrante, um lugar para lavar roupa e uma privada mal instalada. Ladrilhos e calhas geralmente não existiam. Eram variações do cortiço: um prédio único (às vezes um sobrado modificado), excessivamente subdividido; o hotelcortiço de tipo dormitório; e barracões improvisados no fundo de estábulos e armazéns. Todos se caracterizavam por falta de ar, luz, espaço, limpeza, esgotos e solidez de construção. ${ }^{145}$ (MORSE, 1954)

Para aumentar a intervenção, e disciplinar esse tipo de residência, o governo aprovou o Decreto no 233 de 02 de março de 1894:

“(...) Artigo 112: Todas as habitações collectivas deverão dispor de abundante abastecimento de agua potável proporcional ao numero dos domicílios.

Artigo 113: São imprescindíveis banheiros para os moradores.

Artigo 114: As latrinas e todas as installações hygienicas deverão obedecer aos princípios estabelecidos para as habitações em geral.

Artigo 115: Devera haver uma latrina para cada grupo de 20 moradores". ${ }^{146}$

\footnotetext{
${ }^{144}$ FRICK, John. Ar Puro. Rio de Janeiro ed Leuzinger, 1889.

145 MORSE, Richard M. De Comunidade a Metrópole - Biografia de São Paulo. São Paulo, 1954, Comissão do IV Centenário da cidade de São Paulo, 1954, p. 210.

${ }^{146}$ SÃO PAULO. Leis e Decretos. Decreto no 233 de 2 de Março de 1894. O Presidente do Estado, para a execução do artigo 3ำ da Lei o 240 de 4 de Setembro de 1893, estabelece o Código Sanitário.
} 
No mesmo Diploma Legal, o artigo 104, define que, todos os edifícios destinados a conter permanentemente grande número de habitantes, deverão ser construídos fora da aglomeração urbana, ou seja, as autoridades, acabam proibindo este tipo de habitação, e a população mais pobre, aos poucos, é afastada do centro da capital paulistana, ou seja é segregada.

Os autores do Código de 1894, foram influenciados pelos princípios da teoria miasmática, e acreditavam que tudo que estava parado ou estagnado, o ar, a água, os dejetos, o lixo e os próprios homens, eram fatores de doenças. Os vapores emanados dos processos de putrefação da matéria animal ou vegetal, os miasmas, seriam os causadores das epidemias. Portanto, segundo essa teoria, era mister a adoção de preceitos de higiene, medidas de saneamento, que resultassem em uma intensa assepsia do meio físico e social, pois onde imperava a sujeira, a concentração e o amontoamento, criava-se um ambiente propício à formação de miasmas e de doenças.

Surge, a "teoria social da doença", que afirmava serem as péssimas condições de trabalho, e de moradia dos trabalhadores, a má alimentação, os ambientes insalubres, a extrema pobreza, os fatores que identificavam a doença como fenômeno social. ${ }^{147}$

Pelo exposto, à medida que a cidade capitalista se expande "com a crescente atuação da iniciativa privada, o Estado vai deixando de ser o agente da produção do espaço na Cidade, só interferindo normativamente, ou no momento em que é necessário estabelecer a interligação entre os vários loteamentos esparsos, na procura de conferir alguma coesão à colcha de retalhos a que se vai reduzir a estrutura urbana paulistana". ${ }^{148}$

Desde os últimos anos do século XIX, eram plenamente visíveis os novos padrões de vida na urbe paulistana; sua "transformação gradual", envolvia o alargamento de ruas que estavam atravancadas, com excesso de veículos de tração animal, pedestres e vendedores, e foi uma das desculpas para alijar da Capital, as classes populares por meio da demolição dos cortiços

No caso de São Paulo, a solução "vanguardista" para o princípio do caos da nova aglomeração urbana, seria a derrubada das antigas construções, inspirando-

\footnotetext{
147 URTEAGA, Luiz. Miseria, miasmas y microbios. Las topografías medicas y el estudio del medio ambiente en el siglo XIX. Barcelona: Revista Geo Critica, no 29, 1980, p. 35.

${ }^{148}$ CAMPOS, E. São Paulo: desenvolvimento urbano e arquitetura sob o Império. In História da Cidade de São Paulo, vol. III, São Paulo, Editora Paz e Terra, 2004, p.224
} 
se, ainda que, de modo difuso, no modelo de cidade implantado em Paris, pelo Barão Haussmann ${ }^{149}$, procurando transformar a paulicéia no lugar da realização plena da vida moderna.

Artigo publicado no Diário Popular de 1892, ilustra a afirmação anterior:

"Sabe-se o que foi o velho Paris, o Pais de la Cite, antihygiênico, com o seu dédalo de ruas estreitas, em que se acotovelava uma população anémica e rachitica. Entretanto, um prefeito empreendedor sem ousar tocar-lhe fogo, como 0 fizera Nero aos velhos quarteirões de Roma em um dia de capricho, applicou-Ihe a picareta e os empréstimos, operando em vinte anos essa prodigiosa transformação, de que por muito tempo se ressentiram talvez as nossas finanças, mas que faz exultar a higiene.

Sem a pretensão de realizar o arrojado commetimento do Barão de Haussmann, e menos imitar os caprichos de Nero, é tempo de cuidar-se seriamente da transformação gradual desta Capital, subordinando-a a um plano de antemão assentado.

É certo que não nos é lícito reclamarmos a demolição de uma cidade, para reconstruí-la de acordo com as exigências hygienicas; mas, à proporção que se vae ella estendendo, taes exigências podem e devem ser strictamente attendidas; por outro lado, os prédios, os edifícios, como os homens envelhecem, mas com o privilegio, que a estes não assiste, de renascerem; dando ensejo, nessa ocasião, de observarem-se as prescripções higienicas". ${ }^{150}$

Delineava-se assim, de forma explícita, uma expansão urbana sob a égide do conceito de remodelação ditado pelo saneamento. Por outro lado, o excesso de população para a falta de espaço disponível, tornou necessário que o meio tropical fosse saneado, o que evitava a proliferação de moléstias vindas do exterior, criando ambiente salubre, com o objetivo de atrair mão-de-obra e investimentos estrangeiros.

O adensamento populacional, muito acentuado a partir da imigração subvencionada, que tinha o objetivo de suprir a cafeicultura e a industrialização que

\footnotetext{
${ }^{149}$ Barão Haussmann foi prefeito de Paris de 1852 a 1870. Neste período remodelou completamente a capital francesa à revelia das populações pobres, gerando uma especulação imobiliária e um modelo de cidade considerada moderna.

150 DIÁRIO POPULAR - Série de artigos publicados no ano de 1892, com o título de Questões de Actualidade. Saneamento de S. Paulo, Capítulo X, Companhia Cantareira.O articulista usa o pseudônimo de A..., p.p. 35,36 Acervo do Arquivo do Estado.
} 
se iniciava, traz consigo uma mudança de postura do poder público, com as áreas urbanas marginais, dos rios e córregos, consideradas as mais desfavoráveis e menos valorizadas da cidade, e destinada às camadas sociais inferiores, como a região do Brás e da Mooca, que eram vistas como focos de moléstias epidêmicas e toda sorte de distúrbios sociais.

Com essas preocupação, em abril de 1892, o governo estadual criou a Comissão de saneamento, que foi responsável pelo estudo e implantação da retificação dos rios Tamanduateí e Tietê.

Nessa mesma época, em função do avanço dos conhecimentos científicos, que abandonando, em parte, a teoria miasmática, nos estudos das relações entre os microorganismos presentes na água, os hábitos de higiene, a disponibilidade de tratamento de esgotos, e a propagação de doenças, será exigida a presença cada vez maior do Estado, no desenvolvimento de projetos, para a instalação de eficientes sistemas de saneamento, de abastecimento e controle das águas.

"A água só irá adquirir valor depois das descobertas de Pasteur ${ }^{151}$ : estas farão da lavagem das mãos uma nova obrigação social."152 Suas pesquisas semeiam o medo dos micróbios na opinião pública.

Será ao longo do século XIX, que a captação e a distribuição de água, atingirá seu auge entre os britânicos. A Europa seguirá a escola inglesa, e a obra de Hellyer uma vez traduzida na França por Poupard ${ }^{153}$ e a de Humber ${ }^{154}$ serão fundamentais para os engenheiros envolvidos no moderno sistema de abastecimento paulistano.

\footnotetext{
${ }^{151}$ Químico e biólogo francês, Louis Pasteur 1822 - 1895. Em 1862, formulou a teoria dos germes como causadores das doenças, mudando a história da medicina. Muitas doenças inexplicáveis passaram a ser compreendidas.

${ }_{152}$ GUERRAND, Roger-Henri. Espaços Privados in PERROT, Michelle (org) História da Vida Privada Da Revolução Francesa à Primeira Guerra. São Paulo, Cia das Letras, 1991, p. 337.

153 POUPARD, Aîné, La Plomberie au Point de vue de La Salubrité des Maison par S. Stevens Hellyer, Traduit de L'Anglais, Paris, Librairie Génélarle de L'Architecture et des Travaux Publics, 1886. Obs: Poupard, empresário parisiense que enviou seu filho para um estágio com Stevens Hellyer e traduziu sua obra.Publicada sob o patrocínio da Chambre Syndicale des Entrepeneurs de Plomberie de la Ville de Paris.

${ }_{154}$ HUMBER, William.A Comprehensive Treatise on the Water Supply of Cities and Towns, London, Crosby Lockwood and Co, 1876.
} 


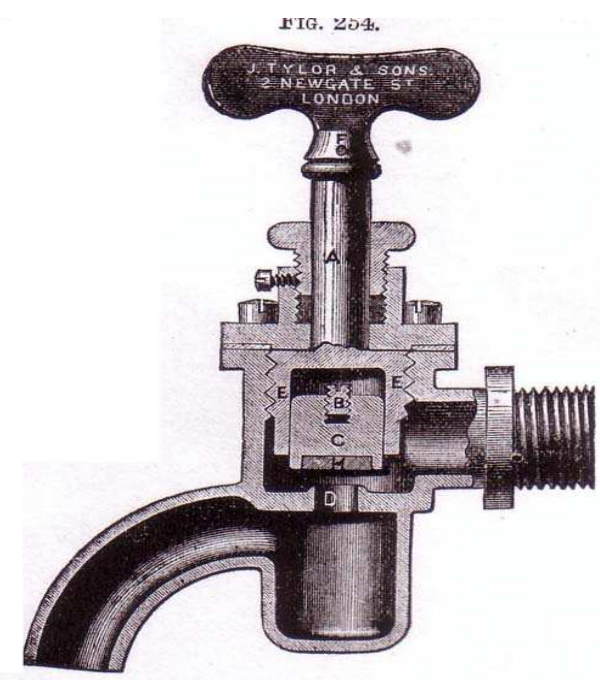

Fig. 257.

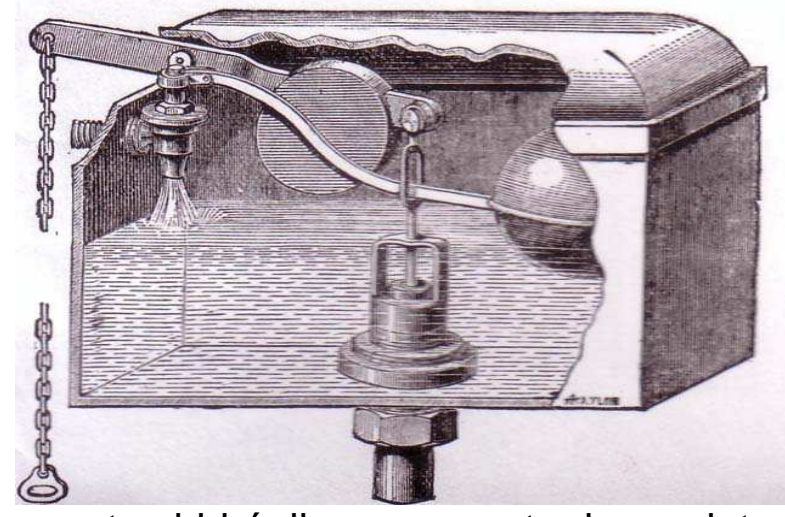

Novos equipamentos hidráulicos, proposta de sua introdução nas residências modernas $^{155}$

O poder econômico e o aumento populacional definiam os tipos de habitação. Num extremo, passaram a existir as chamadas casas populares e os cortiços e, no outro, o palacete.

Tal era, pois, em algumas pinceladas, a divisão das classes em 1890. Em termos de bem estar material, seus extremos estavam à maior distância do que em tempos mais antigos. Entretanto, a complexidade e o anonimato da metrópole tinham levado à desintegração muito dos antigos determinantes de classe. Por esta razão a disparidade entre o palacete e o cortiço constituía uma ironia e deu lugar a um mal-estar que a coexistência do sobrado e da choça de pau-a-pique não tinham comportado. ${ }^{156}$ (MORSE, 1954)

\footnotetext{
${ }^{155}$ HUMBER, William. A Comprehensive Treatise on the Water Supply of Cities and Towns, London, Crosby Lockwood and Co, 1876, p.217.

${ }^{156}$ MORSE, Richard M. De Comunidade a Metrópole - Biografia de São Paulo. São Paulo, 1954, Comissão do IV Centenário da cidade de São Paulo, 1954, p.210.
} 
A maior densidade demográfica com a conseqüente ocupação do espaço, precisava de melhoria nos meios de transporte, no abastecimento de produtos alimentícios, na quantidade de vestimentas a um preço acessível, na mudança dos materiais de construção mais duráveis, e na separação entre trabalho e vida privada.

\subsection{A cidade industrial}

A industrialização, acaba sendo também uma resposta possível ao aumento populacional, dependendo da capacidade de suprir o mercado consumidor, adaptando-se às novas exigências da sociedade em expansão.

A obrigatoriedade da instalação de equipamentos exigidos nas residências, com o Código Sanitário de 1894, como torneiras, sifões, ralos, caixas de água, vasos sanitários, e banheiras, poderia ter gerado, naquele momento, uma oportunidade para o surgimento de uma indústria paulistana neste setor, mas parece que não foi o que aconteceu.

A dificuldade de quantificar as habitações que possuíam equipamentos exigidos pela lei, esbarra na esfera do particular, uma vez que o Poder Público não tinha uma fiscalização adequada.

Os relatórios da Repartição de Águas e Esgotos, relacionam a quantidade de prédios ligados à rede de distribuição, mas se omite a respeito dos equipamentos privados usados nas moradias.

Porém, quando o Estado resolveu equacionar os problemas suscitados com descumprimento dos artigos do Decreto no 233 de 2 de março de $1894^{157}$, que obrigava a instalação desses materiais, viu-se compelido a fornecê-los.

157 SÃO PAULO. Leis e Decretos. Decreto oㅜ 233 de 2 de Março de 1894. O Presidente do Estado, para a execução do artigo 3을 Lei no 240 de 4 de Setembro de 1893, estabelece o Código Sanitário. (.....) Artigo 51: A bacia de águas servidas deverá ser feita com material impermeável de superfície lisa e sem guarnições de madeira.

Artigo 52: Os encanamentos que exgottam estas bacias deverão ter o syphão hidráulico interceptor, munido de ralo e caixa de graxa.

(.....)

Artigo 54: Todos os edifícios e habitações deverão ter canalização especial de conducção das aguas pluviaes directamente para os exgottos ou sargetas das ruas, nas localidades onde não houver exgottos, devendo ser prohibido exgottamento das aguas para as calçadas dos passeios. 
Em 1902, o relatório da RAE revelava que depois das fortes chuvas ocorridas em Novembro de 1901, a empresa resolveu reduzir a capacidade da rede de drenagem e passou a instalar ralos, nos quintais das casas situadas na zona baixa da cidade, como era o caso do Cambuci e da região do Brás, numa tentativa de evitar o refluxo de esgoto, quando ocorria o transbordamento dos rios Tamanduateí e Tietê.

O exame dessa fonte, atesta o aprofundamento do emprego de bacias sanitárias, fornecidas pela empresa, sem explicitar as zonas da cidade que se beneficiavam desse serviço. A documentação, por outro lado, não permite compreender os motivos dessa escolha. Sem indicadores precisos, a análise fica comprometida, e sem resposta: seria uma deficiência de fabricação, de importação, ou de falta desses produtos nas lojas especializadas?

Contudo, a RAE, procurando o cumprimento de uma maior eficiência na área sanitária, foi obrigada a interferir de maneira direta no espaço urbano, e no doméstico. E ao assumir a colocação de ralos e vasos sanitários, fica evidente que se dependesse dos proprietários dos imóveis, esses equipamentos não seriam instalados.

Um sistema apropriado de captação e distribuição de água dependia também do progresso da indústria hidráulica que poderia proporcionar maior eficiência no represamento e nos encanamentos de distribuição de água.

Artigo 56: Não deverá ser permittida latrina, destinada ao uso commum dos moradores, unida aos aposentos de dormir. Não estão neste caso as dependências de toilette.

(.....)

Artigo 59: Deverão ser prohidas as caixas de madeiras para revestimento dos apparelhos hygienicos. Artigo 60: A bacia ou receptáculo das latrinas deverá ser de material impermeável sólido, polido interiormente, sem relevos nem ornatos. Os apparelhos munidos de fundos moveis de válvulas deverão ser condemnados nas habitações a construir de ora avante.

(.....)

Artigo 62: Todas as latrinas deverão ter syphão simples em-S, com interceptor hydraulico.

Artigo 70: As caixas deverão dar descargas provocadas ou automáticas intermittentes, convenientemente calculadas.

(.....)

Artigo 74: Os encanamentos das aguas servidas de cozinha, banheiros e lavatórios deverão ser separados dos exgottos por meio de interceptor hydraulico.

(.....)

Artigo 112: Todas as habitações collectivas deverão dispor de abundante abastecimento de agua potável proporcional ao numero dos domicílios.

Artigo 113: São imprescindíveis banheiros para os moradores.

Artigo 114: As latrinas e todas as installações hygienicas deverão obedecer aos princípios estabelecidos para as habitações em geral.

Artigo 115: Devera haver uma latrina para cada grupo de 20 moradores. 
As obras de saneamento funcionaram como vetores de pressão para novos empreendimentos, na execução dos serviços, na importação, na fabricação, e aperfeiçoamento de materiais de construção.

Ao lado dos empresários do café, começavam a despontar os industriais estrangeiros.

O fazendeiro de café, transformado no "coronel" e no homem de negócios, ocupava os postos-chave da estrutura econômica, política e social. Era o principal agente da passagem do capitalismo comercial e financeiro externo para o interno. O imigrante, por sua vez, colocava-se nas funções emergentes desse processo, desde assalariado a homem de negócios. ${ }^{158}$ (HOMEM, 1996)

Foi o caso de Alexandre Siciliano, nascido em S. Nicola Arcela, na Calábria, Itália, fundador de uma das primeiras empresas paulistanas a ser atraída para as novas oportunidades, a Companhia Mechanica Importadora, que se fundiu com as firmas Lacerda Camargo \& Comp. E Engelberg, Siciliano \& Comp, sendo fundada em 6 de Setembro de 1890. Em pouco tempo se tornou um dos empreendimentos mais importantes da urbe paulistana, e sua presença passa a ser assinalada nas plantas da cidade.

Em seus estatutos constava que tinha por fim:

Negociar em tudo que possa ser comprehendido na classe de machinismos, fabricação, construcção e importação de machinas, materiaes para estradas de ferro, para abastecimento de água, para illuminação e dependências; importação em geral e empreitadas, exploração de privilégios, concessões e contractos para fornecimentos de construcções civis, navaes, hydraulicas, etc. ${ }^{159}$ (PINTO, 1979) (grifo nosso)

Suas instalações, ocupavam uma área de trinta mil metros quadrados entre as ruas Monsenhor Andrade, e Américo Brasiliense, (no mapa indicadas com o

\footnotetext{
158 HOMEM, Maria Cecília Naclério, O Palacete Paulistano e Outras Formas Urbanas de Morar da Elite Cafeeira. 1867 - 1918. São Paulo. Martins Fontes. 1996. p. 117.

${ }_{159}$ PINTO, Alfredo Moreira, A Cidade de São Paulo em 1900. Coleção Paulística vol. XIV, São Paulo. Governo do Estado de São Paulo, 1979, p. 215.
} 
número 46), próximas aos armazéns do Pari, no bairro do Brás, e ao edifício da Alfândega em São Paulo.

Segundo relato da época, em 1900, possuía várias oficinas, sendo a fundição, onde trabalhavam oitenta operários, com uma produção de oitenta toneladas por mês de material fundido, era uma das maiores da cidade, com dois fornos e máquinas, alimentadas por motor a vapor de $16 \mathrm{hp}$, da firma inglesa Robey, da qual a Cia Mechanica, era a representante em São Paulo.

Tinha ainda uma carpintaria com máquinas a vapor, e um setor onde fabricavam máquinas para beneficiamento de café, como descascadores, ventiladores para o grão descascado, despolpadores, e separadores, telas de arames e diversos motores hidráulicos.

Junto à fábrica, estava o armazém de produtos importados, principalmente aqueles referentes ao ramo mecânico. No setor de matéria prima, o destaque era para o depósito de madeiras nacionais. Nesse ramo de atividade, se encontravam as fábricas mais numerosas, uma vez que, "correspondem às necessidades sempre em augmento da cidade, que cresce de dia para dia: ocupam 502 operários e força motriz de 330 cavallos." 160

Em outro prédio, situado na Rua do Triunfo, no primeiro andar, (no mapa indicado com o no 45), com a oficina mecânica, a administração, com 60 funcionários, e 4 engenheiros mecânicos, os ateliês de desenhos, e o depósito e mostruário de móveis de madeira, produzidos pela empresa.

160 SÃO PAULO. Relatório da Repartição de Estatística e Archivo apresentado ao Secretário dos Negócios do Interior do Estado de S. Paulo, em 30 de setembro de 1895. São Paulo Typographia da Companhia Industrial de S. Paulo. 1896. p.192. 


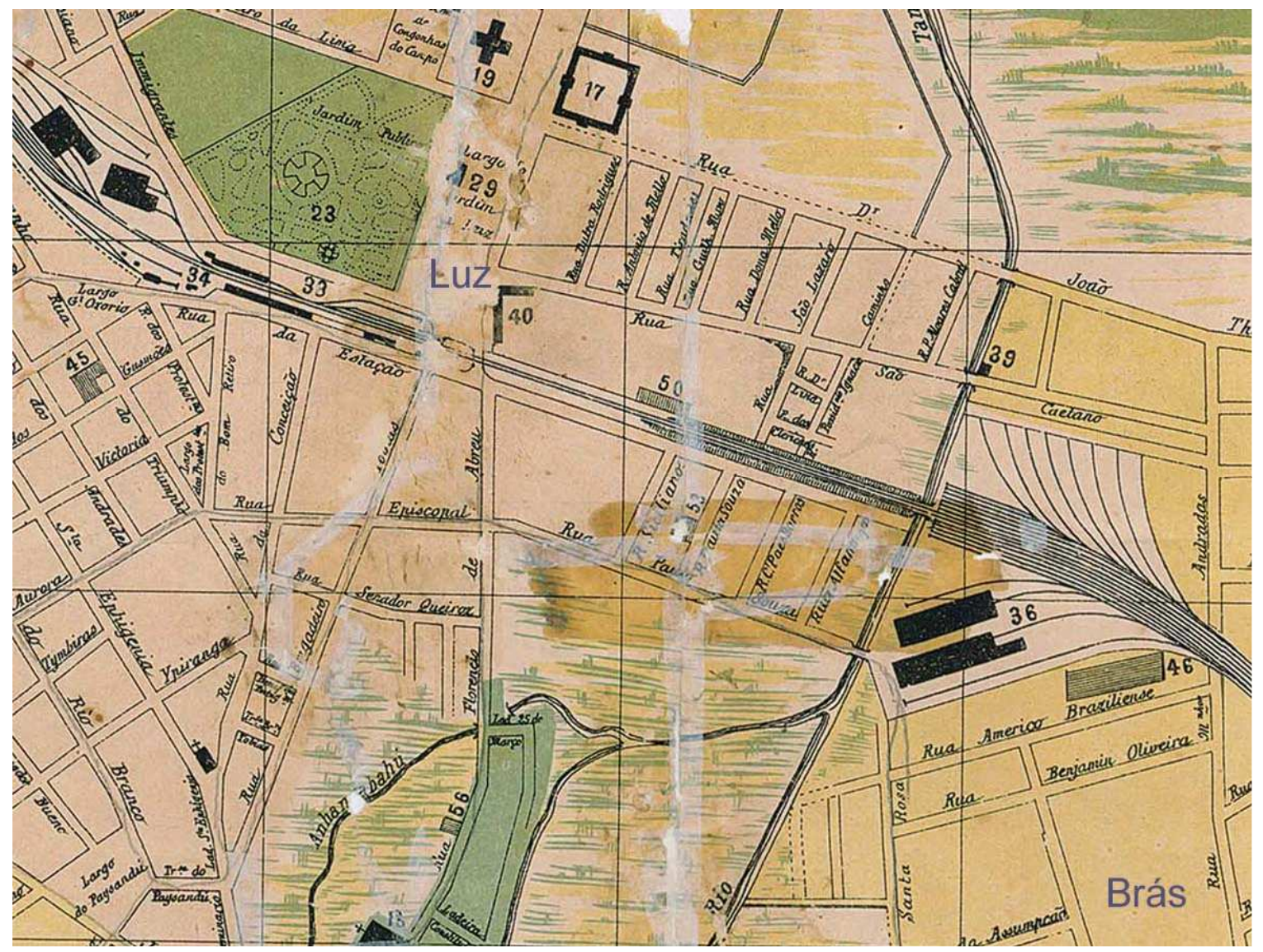

Planta da Cidade de São Paulo com referenciaes e indicação do principaes edifícios públicos e de Casas Commerciaes e Industriaes Escala 1:10.000 1895 Editor Hugo Bonvicini

No térreo, estava a caldearia, a ferraria, a tornearia, com máquinas movidas por motor Robey de 90 hp.

Entre os maiores compradores de seus produtos, além do Estado de São Paulo, estavam o Rio de Janeiro, Minas Gerais e Espírito Santo.

Conforme relatório da Repartição de Estatística, em 1895, a Cia tinha 250 operários, todos homens, aos quais pagava em média $6 \$ 000$ por dia de trabalho, pouco, para a sobrevivência dos trabalhadores, porém, acima do que pagava o mercado. ${ }^{161}$ Salário Mensal: $180 \$ 000$.

A título de comparação, no mesmo ano, a São Paulo Railway Company, de capital inglês, possuía 300 operários, aos quais pagava $4 \$ 700$ por dia. Salário Mensal: $141 \$ 000$.

161 SÃO PAULO. Relatório da Repartição de Estatística e Archivo apresentado ao Secretário dos Negócios do Interior do Estado de S. Paulo, em 30 de setembro de 1895. São Paulo Typographia da Companhia Industrial de S. Paulo. 1896. p.191. 
A Estrada de Ferro Central do Brasil, tinha 288 empregados, sendo 5 técnicos, 247 homens e 36 meninos, com salários entre $1 \$ 500$ a $4 \$ 500$ por dia. Salários: $45 \$ 000$ e $135 \$ 000$.

Uma das maiores fábricas de tecidos, a Santa Maria, situada no Brás, empregava 40 homens, 360 mulheres e 40 crianças, com ordenados de $1 \$ 000$, $2 \$ 500$ e $4 \$ 000$ por dia. Salários mensais: $30 \$ 000,75 \$ 000$ e $120 \$ 000$.

A Companhia de Gás, ocupava 289 pessoas, todos homens e pagava em média, o mesmo salário da Cia Mechanica, 6\$000 por dia. Salário mensal: $180 \$ 000 .^{162}$

Em 1892, ou seja, 3 anos antes, com esses rendimentos os trabalhadores viviam em situação desesperadora, afinal, para um operário ser considerado de classe média, precisava receber pelo menos $\mathrm{R} \$ 500 \$ 000$ por mês.

Segundo o jornal Diário Popular, uma família pequena não podia mais viver com esse valor por mês, pois era vítima :

“(...) do excessivo preço dos gêneros de primeira necessidade, a carestia do vestuário, a quase impossibilidade de pagar-se o serviço domestico, o collegio de educação, o medico, a botica, o combustível escasso e sobretudo, o conjucto enorme de necessidades que creamos e que não mais se póde deixar de satisfazer, tudo isso unido a falta de previdência, a ausência de sociedades cooperativas de consumo, aos desastres do jogo da bolsa no período vertiginoso da expansão do crédito $(. . .)^{163}$

Em 1900, a companhia tinha dobrado o número de operários, 500, em sua maioria imigrantes, que trabalhavam 54 horas por semana, com salários de 450 a $1 \$ 000$ por hora de serviço, perfazendo $R \$ 97 \$ 200$ a $R \$ 216 \$ 000$, por mês ${ }^{164}$.

Considerando esses dados, em cinco anos a empresa teve um crescimento impressionante, e embora os valores dos salários tivessem melhorado, ainda assim, esse funcionário estava longe de ser considerado como classe média.

Essa mão-de-obra, através de suas oficinas, executou

\footnotetext{
162 Os salários constam do Relatório da Repartição de Estatística e Archivo apresentado ao Secretário dos Negócios do Interior do Estado de S. Paulo, em 30 de setembro de 1895. São Paulo Typographia da Companhia Industrial de S. Paulo.1896

${ }_{163}$ DIÁRIO POPULAR,12 de março de 1892, p.02.

164 PINTO, Alfredo Moreira, A Cidade de São Paulo em 1900. Coleção Paulística vol. XIV, São Paulo. Governo do Estado de São Paulo, 1979, p. 211 a 215.
} 
(...) artigos com acabamento finos, como candelabros que ornamentam os jardins do Teatro Municipal de São Paulo, as colunas de iluminação das avenidas Rio Branco e Beira Mar no Rio de Janeiro, as colunas do Palacete Martinica, além de várias pontes para a Companhia Araraquarense de Estadas de Ferro, telhados mecânicos para a Companhia Mogiana, algumas máquinas do Moinho Matarazzo, a superestrutura metálica da Casa Alemã, dos teatros São José e Sant'Anna. Além disso, é responsável por parte do suprimento de ferramentas e máquinas para a indústria, como serras, prensas, turbinas, moinhos para arroz e milho, engenhos pra açúcar, guindastes, reservatórios, elevadores, carrosséis para automóveis, engrenagens de toda espécie etc. ${ }^{165}$ (CARONE, 2000)

Em 1893, quando o Estado assume as obras de saneamento, os investimentos públicos se voltaram também para o aumento da rede de esgotos, em razão dessa assertiva, um ramo de atividade que passa a ter importância no mercado interno, é o da fabricação de tubos de barro vidrados, as manilhas.

Independentemente das diversas seções que formam as oficinas e os armazéns do Pari, possui a Companhia uma unidade produtiva destinada à cerâmica, no bairro da Água Branca, onde se fabricam em larga escala materiais de saneamento urbano. ${ }^{166}$ (CARONE, 2000)

Para a instalação dessa rede de serviços, a R.A.E., passa a adquirir material da Cia. Mechânica, que se une através de contrato, com as concorrentes, a cerâmica Sensaud de Lavaud \& Cia, e a Companhia Progresso Paulista, para a fabricação desse tipo de tubos, formando o primeiro "looby" industrial brasileiro. O grupo, se tornou o fornecedor exclusivo desse produto em todo o Estado de São Paulo. As três empresas formaram um cartel no setor cerâmico, não sendo possível produzir-se mais barato, os produtos que somente elas forneciam.

Outro industrial de destaque, é o paulista Antonio Proost Rodovalho, proprietário da Companhia Cantareira de Águas e Esgotos. Em 1877, mesmo ano da fundação da empresa, resolve construir em uma de suas propriedades, dois fornos para a produção de cal, na fazenda Caieiras, às margens do rio Juquery. Em 1889 , contratou técnicos da Alemanha, para montar na mesma região, uma fábrica de produção de papel, a Companhia Melhoramentos de São Paulo, que atuaria também

\footnotetext{
${ }^{165}$ CARONE, Edgard. A Evolução Industrial de São Paulo. 1889 - 1930. Ed Senac. 2000. p. 132

${ }^{166}$ CARONE, Edgard. A Evolução Industrial de São Paulo. 1889 - 1930. Ed Senac. 2000. p. 132
} 
no ramo de materiais de construção, e na importação de equipamentos. Com uma produção de seis toneladas de papel por dia, seu maior desafio residia no transporte dos produtos, que ainda era feito em carroças.

Apesar de todos os contatos com empresários e a elite cafeeira, não conseguia dos ingleses, donos da ferrovia, que passava próxima de sua propriedade, a autorização para a construção de um ramal, e além disso, não tinha, como acontecia com os produtores de café, qualquer desconto nos valores dos fretes.

Em 1894, fundou a Associação Comercial de São Paulo, e um ano depois, enfrentou a maior crise em um de seus investimentos, perdeu 310 toneladas de papel em uma enchente, e foi afetado pela crise do setor cafeeiro, onde tinha vários sócios. Rodovalho, se viu obrigado a fazer empréstimos junto aos Bancos do Rio de Janeiro.

Somente em 1897, quando se tornou acionista da São Paulo Railway, implantou um ramal ferroviário para escoar a produção, mas era tarde demais, para saldar as vultuosas dívidas junto aos banqueiros, viu-se coagido a vender 0 empreendimento.

Em 1893, em sociedade com seu filho, fundou a Rodovalho Júnior \& Cia, dedicada ao setor de transportes, com aluguel de carruagens e carros para ocasiões especiais. Em seguida, assina contrato com a Santa Casa de Misericórdia, que cuidava dos sepultamentos na cidade e consegue a concessão municipal para administrar o serviço funerário, que ficou com a família até 1941.

Em 1897, na Fazenda Santo Antônio, nas proximidades do Município de São Roque, instalou a primeira fábrica de cimento portland do país, a partir da mistura de calcário e argila, calcinadas em fornos. No início do século $\mathrm{XX}$, a usina conhecida como Rodovalho, foi comprada pela A. R. Pereira \& Cia que, ampliando o negócio, construiu outra fábrica de cimento no bairro de Santa Helena, em Votorantin, passando a se chamar "Cimento Votorantin", denominação que mantém até hoje. ${ }^{167}$

$\mathrm{Na}$ realidade, o embrião que originou os primórdios da industrialização em São Paulo, e o desenvolvimento de uma tecnologia própria, está vinculado ao saneamento da cidade, e toda a indústria que está por trás desse equipamento coletivo.

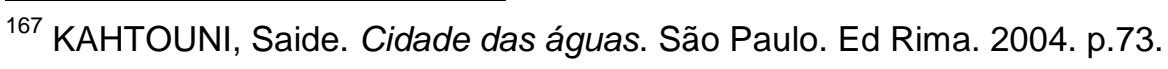




\subsection{Tramway da Cantareira ${ }^{168}$}

Embora algumas circunstâncias, já consagradas pelos estudiosos, favoreceram a economia da cidade de São Paulo, na segunda metade do século XIX, existem opiniões divergentes, a exemplo de Celso Furtado ${ }^{169}$, Wilson Cano ${ }^{170} \mathrm{e}$ Warren Dean ${ }^{171}$, que explicam de maneira diversa, o início da industrialização paulistana, como por exemplo, a substituição da importação, como já se disse acima, a habilidade empresarial dos importadores, o capital gerado pelo complexo cafeicultor, e a substituição da produção artesanal, diante de um mercado consumidor, sempre crescente; todos esses fatores reunidos, foram, talvez, vetores do processo da industrialização.

Não obstante, esse período foi marcado pela construção em 1867, da ferrovia entre São Paulo e Santos, pertencente a São Paulo Railway Co., que deu novo impulso às exportações do café, e a vinda de produtos estrangeiros que fariam parte do quotidiano da elite paulistana de então.

Além dessa empresa, outras passaram a trafegar com seus vagões que transportavam pelo território paulista uma expressiva quantidade de pessoas e, principalmente de mercadorias. ${ }^{172}$

No começo desta estrada férrea, do Planalto, rumo à baixada, desciam café ( $44 \%$ do total faturado po peso transportado), algodão (10\%), açúcar (3\%), toucinho (1\%) e tabaco $(0,7 \%)$; por sua vez, no sentido da Capital, era o sal que ocupava a posição de destaque, com uma participação da ordem de 17\%. A importância da rubiácea viu-se aumentada nos anos seguintes, em função do prolongamento da malha ferroviária em direção a áreas cafeeiras, bem como do declínio das nossas exportações de algodão. ${ }^{173}$ (NOZOE, 2004)

\footnotetext{
168 O Tramway foi instalado em 1893, e funcionou até 1965, ficando conhecido como "trenzinho da Cantareira", será usado, como baliza temporal, apenas o ano de 1894, início de suas atividades, uma vez que foi implantado com a finalidade de levar os materiais necessários para viabilizar a construção das represas e do aqueduto na Serra da Cantareira, seu estudo estará limitado ao nosso objeto de pesquisa. Em São Paulo, a palavra tramway designava uma ferrovia urbana com locomotivas.

${ }^{169}$ FURTADO, Celso. Formação Econômica do Brasil. São Paulo. Cia Ed. Nacional, 2003

${ }^{170}$ CANO, Wilson. Raízes da concentração industrial em São Paulo. Campinas, UNICAMP, 1998.

${ }^{171}$ DEAN, Warren. A industrialização de São Paulo 1880 - 1945. São Paulo. DIFEL, 1971.

172 SAES, Flávio Azevedo Marques de. As ferrovias de São Paulo, 1870 - 1950: expansão e declínio do transporte ferroviário em São Paulo, Hucitec, 1981, p.73.

${ }^{173}$ NOZOE, Nelson. Vida econômica e finanças municipais da Capital paulista na época imperial, in História da Cidade de São Paulo - A cidade no império 1823 - 1889, São Paulo, Paz e Terra, 2004, pp113,114.
} 
Com o tempo, o trem facilitou a vinda de produtos industrializados, e o comércio que até 1860, se caracterizava pelos gêneros de primeira necessidade, passa a contar com uma maior quantidade de produtos importados, voltados para o modo de vida burguês de modelo europeu.

O Poder Público, logo percebe as vantagens desse meio de transporte, estabelecendo os trens de subúrbio, que deveriam conduzir a população à periferia, induzindo a ocupação das áreas fora dos limites da cidade.

As exigências técnicas, e as facilidades de transporte, influenciaram as decisões na localização das unidades fabris e dos serviços. No caso do abastecimento de água, os empreendedores não tiveram escolha, teriam que captar os mananciais onde quer que eles estivessem. Situados a aproximadamente, quinze quilômetros do centro da cidade, estavam em uma região de difícil acesso.

Para facilitar a remessa de materiais às obras de captação de água, a administração pública, evocou a si a solução do problema, implantando uma via férrea, interligada aos galpões da São Paulo Railway, e a Serra da Cantareira ${ }^{174}$, o que exigiu várias desapropriações ${ }^{175}$, e a mudança de traçado de antigos caminhos.

\footnotetext{
174 Segundo PANNEL, em grandes obras de construção como as de abastecimento de água é necessário que o arqueólogo industrial pesquise de que forma os materiais foram transportados, uma vez que geralmente envolvem novas vias de acesso e equipamentos especiais de transporte. In PANNEL; J.P.M. The Techniques of Industrial Archaeology, Great Britain, edited by J. Kenneth Major, 1984, p. 151 a 153.

O mesmo autor recomenda que se consulte o tipo de material empregado pois alguns podem representar inovação na técnica construtiva. Nesse caso, a presença de tijolos e equipamentos hidráulicos. Obra cit. p. 154.

175 SÃO PAULO. Leis, Decretos. Decreto no 184 de 13 de julho de 1893. Declara de utilidade pública, para desapropriação nos termos legais, os terrenos a atravessar pela linha do tramway que se dirige à Serra da Cantareira, constituindo os referidos terrenos uma facha de vinte metros de largo, na extensão da mesma linha, ou de dez metros de cada lado na mesma extensão.
} 


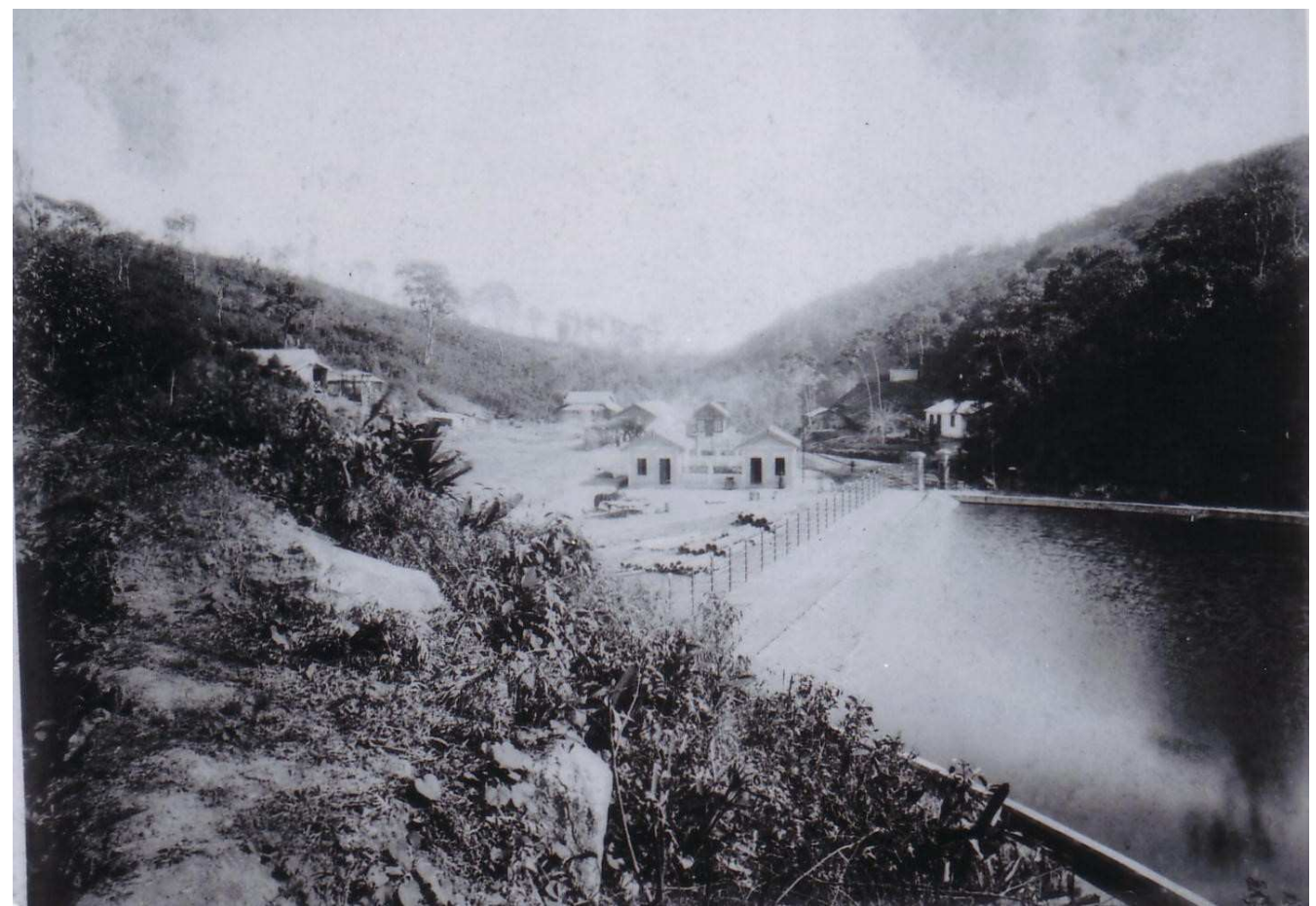

Reservatorio de Accumulação, com o ponto final do Tramway. Foto P. Doumet 1894. Acervo Museu da SABESP Obs. À esquerda o trem parado na Estação.

De acordo ainda com Pannel| ${ }^{176}$, a implantação de ferrovias na Inglaterra, teve como conseqüência a substituição, e ou o reforço, das pontes ao longo do trajeto, o que também ocorreu na linha do tramway.

A instabilidade dos antigos pontilhões, obrigou à construção de estrutura, que teriam de ser adaptadas ao novo delineamento da via férrea, em fase de implantação, e às novas exigências, daí decorrentes.

176 PANNEL, J.P.M. The Techniques of Industrial Archaeology, Great Britain, edited by J. Kenneth Major, 1984. 


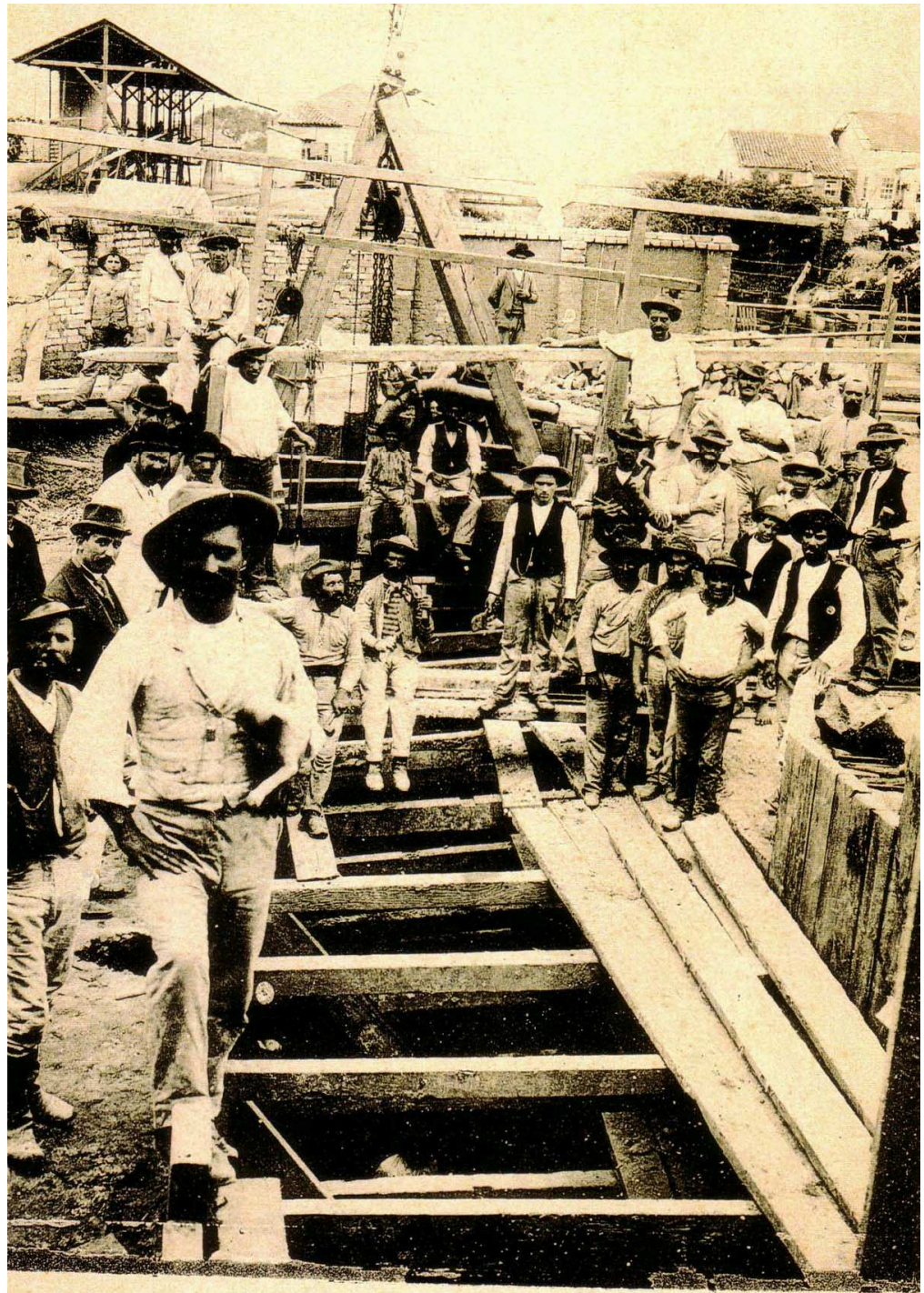

Construcção da ponte da rua S. Caetano

Ilustração da construção da Rua São Caetano

Comissão de Saneamento do Estado de São Paulo. Relatório Annual apresentado ao Exmo Sr Dr Jorge Tibiriçá pelo Engenheiro João Pereira Ferraz em 1894 p. 84

"Consistiram os trabalhos da secção nos projetos de pontes para o canal do Tamanduatehy e para o canal supplementar do Tieté, assim como para aquelas necessárias à linha do Tramway da Cantareira."177

O primeiro trecho foi, entre a Avenida Tiradentes, e o pátio da estação do Pari, onde um acordo firmado com a São Paulo Railway, permitiu fazer a carga e a descarga dos materiais, para a construção da ponte da Avenida Tiradentes, e

177 SÃO PAULO. Relatório Annual da Commissão de Saneamento do Estado de São Paulo apresentado ao Sr Jorge Tibiriça, Secretario da Agricultura pelo Engenheiro Chefe João Pereira Ferraz referente ao anno de 1893, São Paulo, Typographia à vapor de Vanorden e Comp, 1894, p.05. 
daquelas destinadas à serra. A maior dificuldade de execução, foi na região da várzea entre Santana e Pari, que exigiu grande quantidade de aterro.

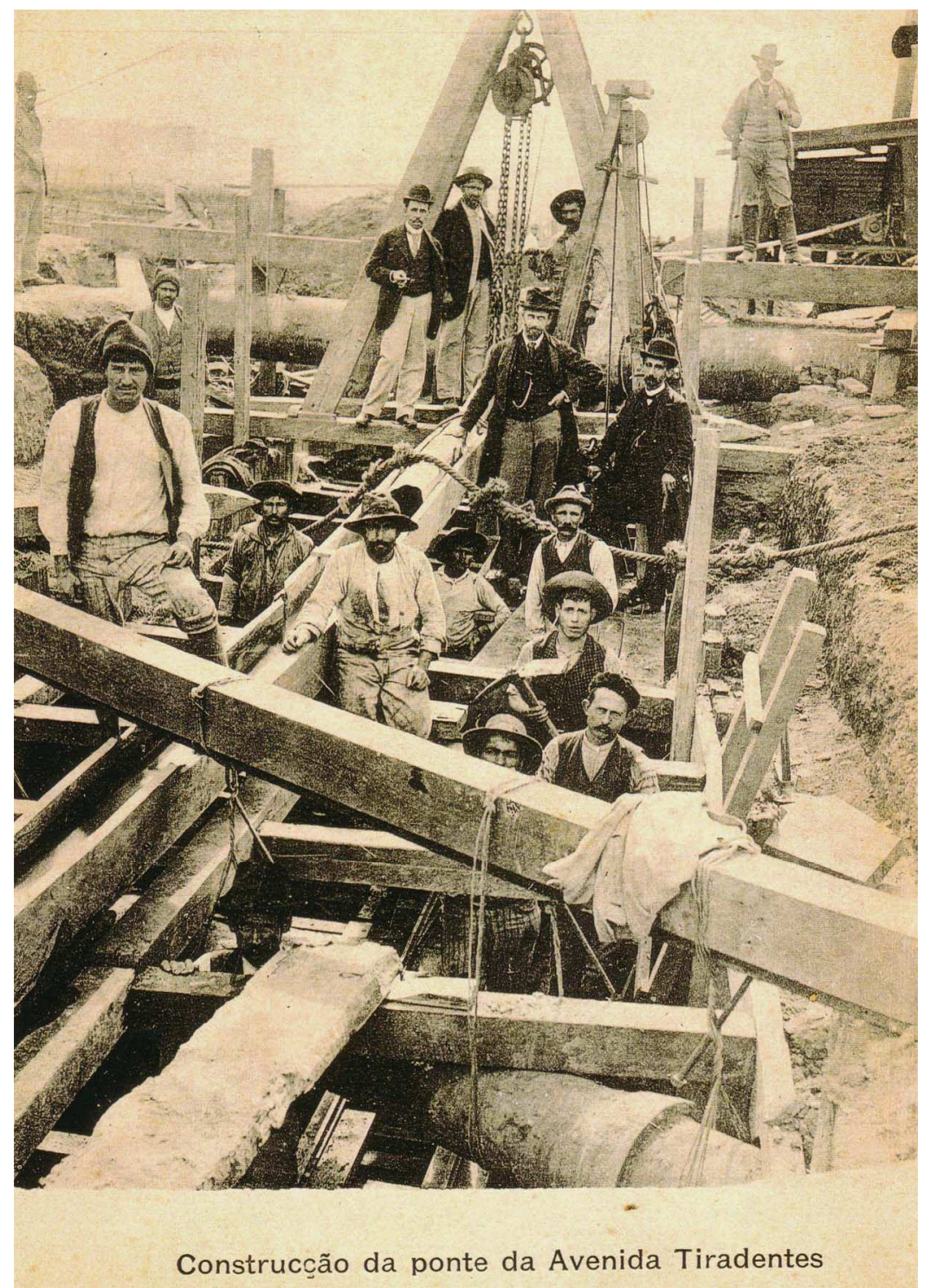

Comissão de Saneamento do Estado de São Paulo. Relatório Annual apresentado ao Exmo Sr Dr Jorge Tibiriçá pelo Engenheiro João Pereira Ferraz em $1894^{178}$

178 COMISSÃO DE SANEAMENTO DO ESTADO DE SÃO PAULO. Relatório Annual apresentado ao Exmo Sr Dr Jorge Tibiriçá pelo Engenheiro João Pereira Ferraz. São Paulo. Comissão de Saneamento. 1894. p.82. 


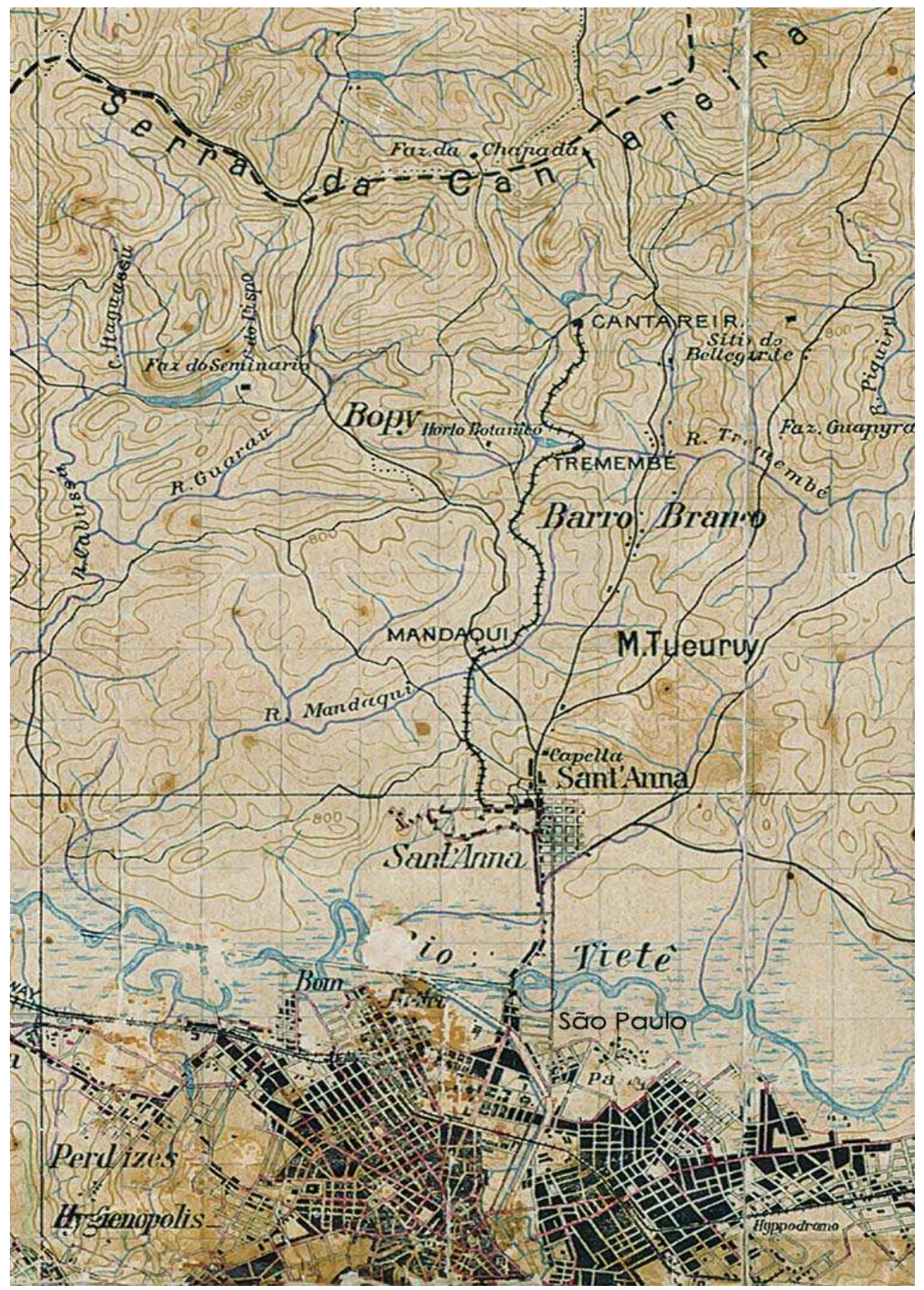

Mapa da linha do tramway, com as estações de Santana, Mandaqui, Tremembé e Cantareira.

Comissão Geográfica e Geológica - Publicação Especial para a Secretaria da Justiça e Segurança Pública - Folha do Município da Capital. Escala 1:100.000 Acervo do Instituto Geográfico e Cartográfico.1904. Obs. No detalhe, linha do tramway, com as estações de Santana, Mandaqui, Tremembé e Cantareira.

O estudo da estrada de ferro, deve defini-la como uma estrutura histórica, capaz de informar o desenvolvimento e progresso tecnológico, alcançado por uma cidade, através dela. ${ }^{179}$

\footnotetext{
179 GARCIA, Mercedes Lopez, "La obra Publica, Investigacion y Practica" in I Encontro Nacional sobre o Património Industrial, vol I Coimbra editora Ltda, Coimbra, 1989, p. 290.
} 
A análise deste microcosmo, que constitui a implantação da linha férrea, inclui entre outros fatores, o material de sua construção e a infraestrutura urbana, necessários para viabilizá-la, o que acarreta mudanças na fabricação de vários produtos, como os tijolos que precisavam ser mais resistentes para este tipo de obra, gerando uma demanda que é acompanhada pelos empresários do setor.

Assim se exprime o chefe da seção da Comissão de Saneamento, em relatório apresentado a 19 de julho:

"Quanto aos tijolos devo dizer que foi adoptada para as obras a melhor classe deste material que existia no mercado proximamente igual ao estrangeiro de melhor fabrico e incontestavelmente superior ao material geralmente empregado nesta Capital.

(...) Posteriormente obteve-se excellente tijolo provinda da fabrica "Vaturantin" de Sorocaba pertencente e mantida pelo Banco União. Ali o producto é de primeira qualidade e houve-se de vencer as difficuldades de transporte o que foi conseguido. Tem sido abundante o fornecimento dessa procedencia e o producto tem sempre melhorado, sob o ponto de vista industrial de forma a apresentar nos ultimos tempos material que se pode reputar sem competidor.

... De varias propostas apresentadas foi preferida a da Companhia Mechanica e Importadora de S. Paulo, com a qual foi lavrado o contracto". ${ }^{180}$

A construção de equipamentos urbanos, ligados a infra-estrutura, contou com a utilização de novos materiais, que o desenvolvimento científico, tecnológico e industrial, do final do século XIX, colocara a disposição das sociedades.

Essas obras, que assumiam cada vez mais seu caráter utilitário, tinham no ferro o elemento construtivo de grande significado. Os engenheiros da Comissão de Saneamento, defenderam sua utilização e conceberam pontes, em que o caráter estético, foi determinado por esse material.

O pioneirismo no uso do ferro, causou alguns embaraços, segundo relatório de 1894, no trecho do Tamanduateí, para assentar os três encanamentos de água de ferro fundido de $32 \mathrm{~m}$ de extensão, foi necessária a construção de andaimes de madeira, que os engenheiros não tinham previsto nos custos da obra. Os canos de

180 SÃO PAULO. Relatório Annual da Commissão de Saneamento do Estado de São Paulo apresentado ao Sr Jorge Tibiriça, Secretario da Agricultura pelo Engenheiro Chefe João Pereira Ferraz referente ao anno de 1893, São Paulo, Typographia à vapor de Vanorden e Comp, 1894, p.06. 
$600 \mathrm{~mm}$, tiveram que ser colocados sobre alças de ferro batido, presas por meio de parafusos às chapas do estrado da ponte.

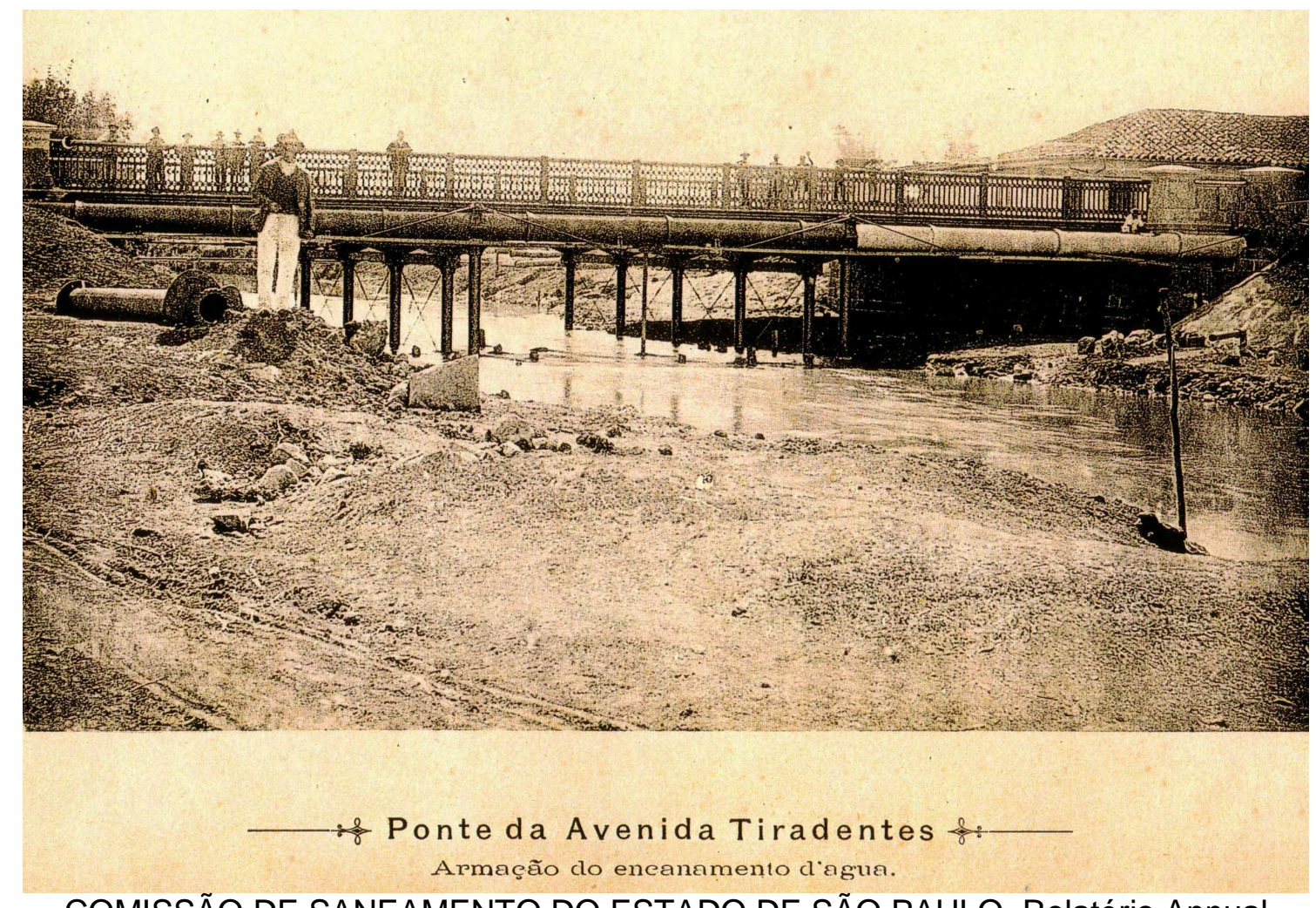

COMISSÃO DE SANEAMENTO DO ESTADO DE SÃO PAULO. Relatório Annual apresentado ao Exmo Sr Dr Jorge Tibiriçá pelo Engenheiro João Pereira Ferraz em $1894^{181}$

Outro problema, ocorreu assim que a ponte foi aberta ao trânsito; o rebaixamento de $80 \mathrm{~cm}$ nos pilares de ferro, obrigou sua interdição, e a revisão de todo 0 projeto. Os técnicos responsáveis, atribuíram o acidente, à vibração dos veículos, e para refazer parte da obra, tiveram que deslocar os encanamentos de água. Essa intervenção teve que ser feita com a maior cautela, de modo a evitar, quanto possível, o corte no suprimento à cidade.

Foi projetada uma armação especial de metal, e para fabricá-la, contrataram a Companhia Mechanica ${ }^{182}$, que também tinha sob sua responsabilidade, a montagem da ponte sobre o rio Tietê.

\footnotetext{
${ }^{181}$ COMISSÃO DE SANEAMENTO DO ESTADO DE SÃO PAULO. Relatório Annual apresentado ao Exmo Sr Dr Jorge Tibiriçá pelo Engenheiro João Pereira Ferraz. São Paulo. Comissão de Saneamento. 1894. p.81.

${ }^{182}$ Fundada em 6 de setembro de 1890, a Companhia Mechanica e Importadora se fundiu com as antigas firmas Lacerda Camargo \& Comp. e Engelberg, Siciliano \& Comp, com capital sócia,I de 5.000 contos de réis, em 25.000 ações de $200 \$$ cada. Em 1900, divulgava que "tem sempre
} 


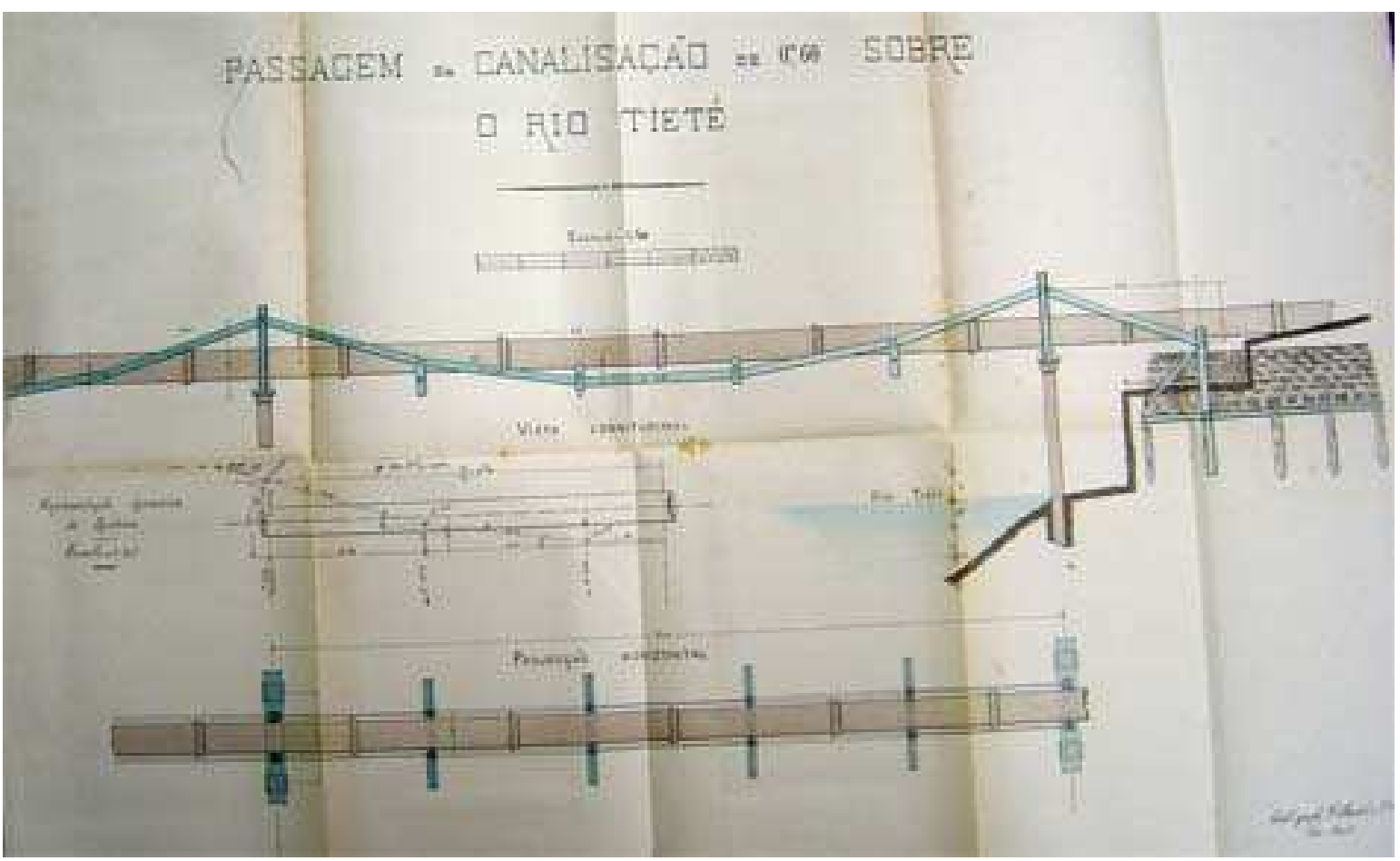

Acervo Arquivo do Estado de São Paulo

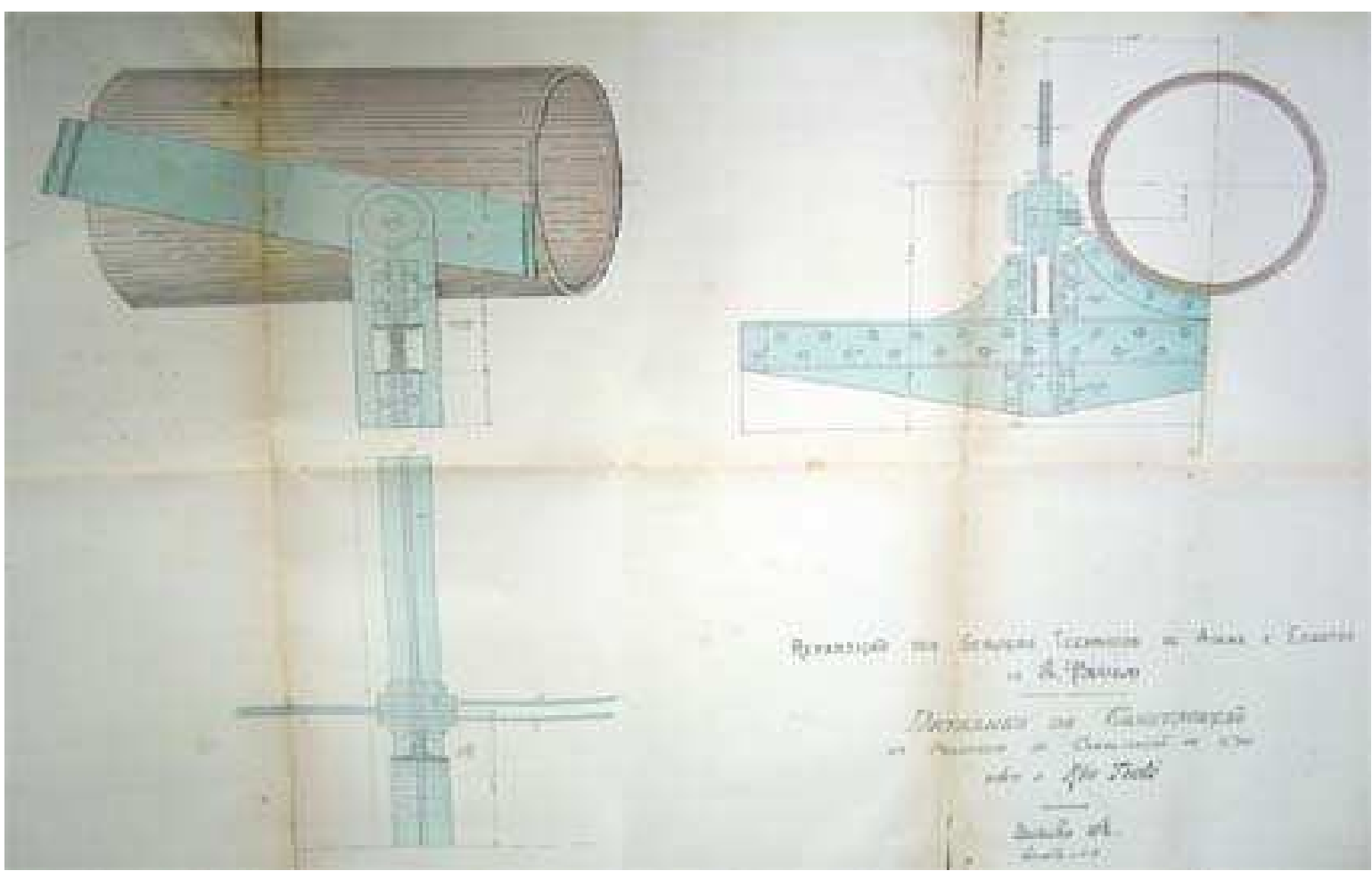

Acervo do Arquivo do Estado

distribuído dividendos aos seus accionistas e, no balanço de 31 de dezembro ultimo, tinha 1.371:142\$223 contos de fundo de reserva e lucros suspensos." 


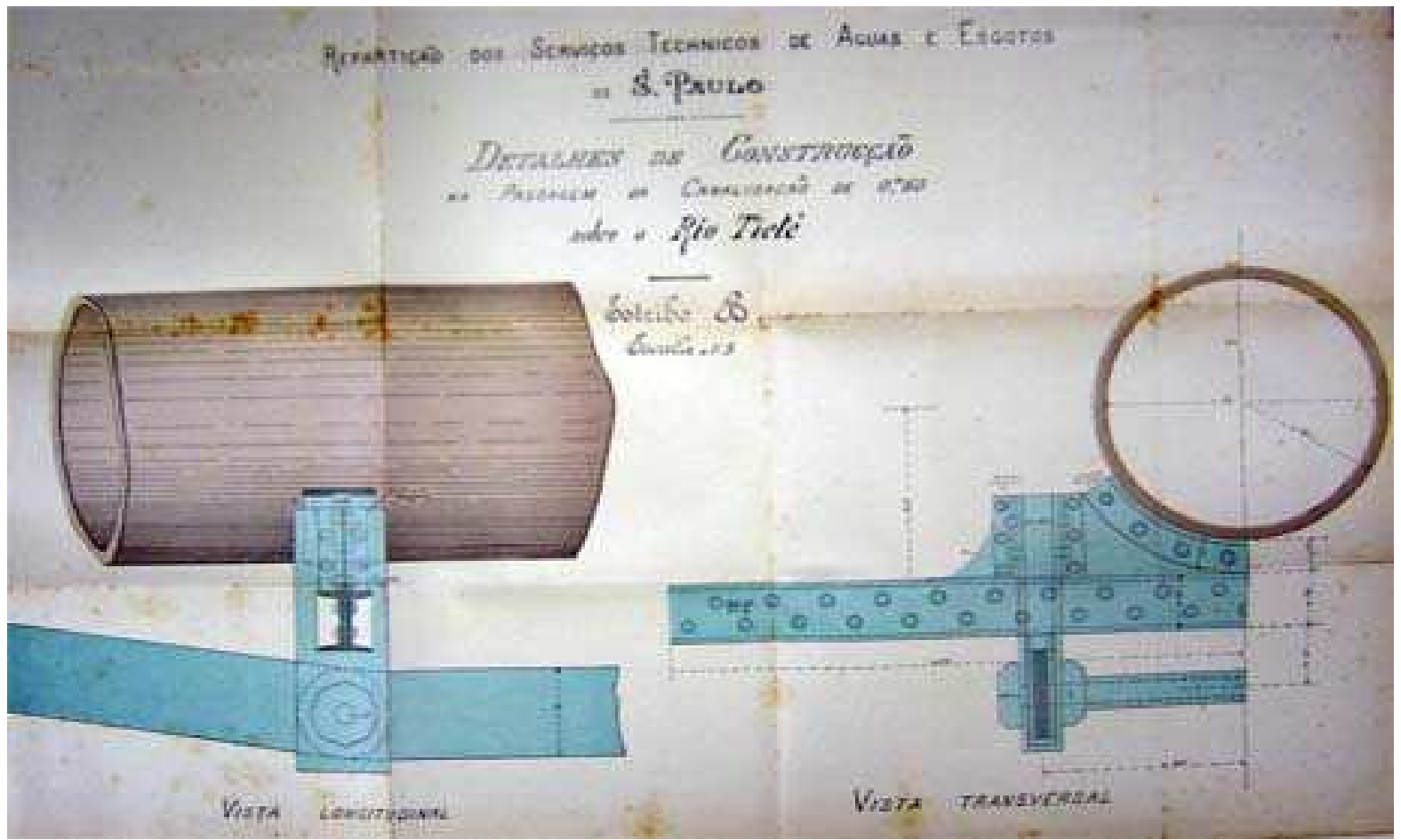

Acervo Arquivo do Estado 


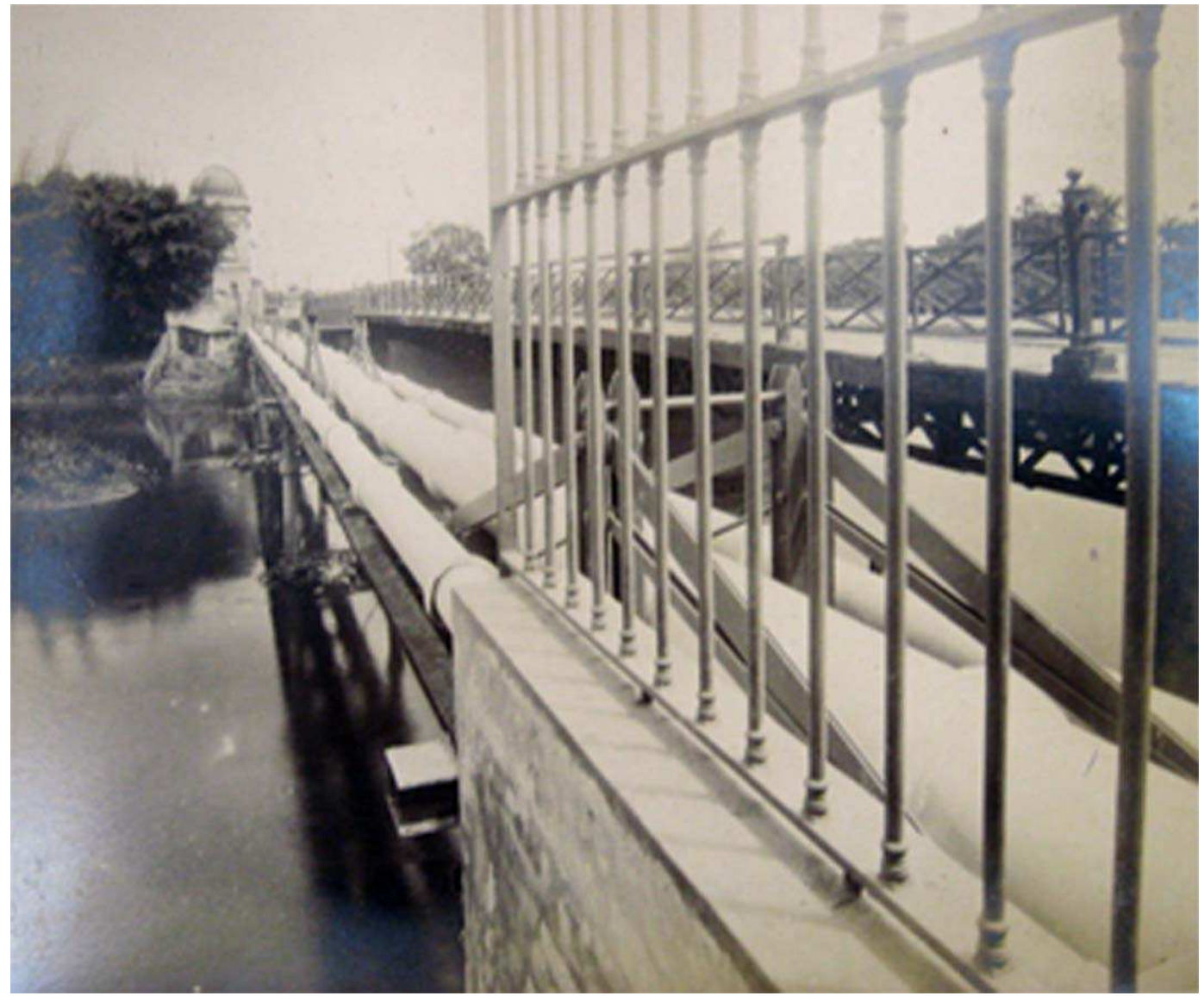

Ponte sobre o rio Tietê foto P. Doumet 1894

Uma vez construídas as pontes, a linha do Tramway, "custeada pelo Governo do Estado e construída tendo por principal objectivo auxiliar as obras de abastecimento de água da Capital, está a prestar, como já o tem feito, serviços de muito valor não só para outras importantes obras públicas como para impulsionar o desenvolvimento da indústria particular e o povoamento de uma grande zona às portas desta cidade." ${ }^{183}$

Em 1894, ano de sua implantação, a despesa foi da ordem de 144:699\$790 e a receita foi de $7: 550 \$ 700$, em 1899 os gastos foram de 260:509\$306 com uma arrecadação de 110:713\$400, com um déficit de 149:795\$906, esta via férrea jamais deu lucro, porém, segundo o responsável pela administração, "O tramway da Cantareira é, como se vê, um gravame para as despesas públicas; mas, attendendose ao fim para que foi construído, que é o de servir ao abastecimento de água da cidade, e aos benefícios indirectos que traz à riqueza publica, fornecendo materiais

\footnotetext{
${ }^{183}$ RELATÓRIO DA SECRETARIA DA AGRICULTURA COMMERCIO E OBRAS PUBLICAS. 1896, p.124.
} 
de construcção para a cidade e abastecendo os seus mercados de consumo, o seu agravame é mais aparente do que real."184

A exigência de melhor via de comunicação, e de transporte mais moderno, gera maior permuta de pessoas e bens, evolução das técnicas e meios de produção, implícita na afirmação do responsável pela Comissão de Saneamento da Cidade, citado acima, e que pode ser constatada no fluxo sempre crescente de passageiros e de produtos.

Em janeiro de 1894, efetuou-se a montagem da primeira locomotiva inglesa, a no 4, que no mesmo mês começou a fazer o trajeto entre a Serra da Cantareira e a cidade.

Segundo parecer de $1895^{185}$, o chefe da Comissão de Saneamento, propõe que os trens de transporte de materiais, fossem adaptados com vagões de passageiros, e passassem a circular, a partir de setembro de 1894, nos domingos e feriados, como opção de lazer para a população paulistana.

Dessa data em diante, os habitantes da região reivindicaram que o serviço se estendesse aos outros dias da semana, e assim foi feito, a linha passou a contar com dois trens para o tráfego público, um de manhã, e outro a tarde.

O equipamento que inicialmente foi implantado para carregar materiais de construção para a captação e distribuição de água, acaba sendo incorporado, como via de comunicação, por excelência, estreitando os laços entre a zona rural e a urbana.

Com o passar do tempo, e a ocupação da Zona Norte, o tramway se transformou em meio de transporte para milhares de pessoas, expandindo a malha urbana, anexando novas áreas à ocupação inicial da cidade, embora continuasse com bitola de $0,60 \mathrm{~m}$, ficando em funcionamento até 1965 , quando foi desativado e substituído, em parte de seu trajeto, pelo metrô, no início da década seguinte.

No primeiro semestre de 1894, a lista de materiais transportados pelo tramway, para a construção dos reservatórios foi a seguinte:

\footnotetext{
184 SÃO PAULO. Relatório correspondente ao ano de 1899, apresentado ao Presidente do Estado Coronel Fernando Prestes de Albuquerque pelo Alfredo Guedes Secretário da Agricultura, São Paulo, Typographia do Diário Official, 1900, p.139.

${ }^{185}$ SÂO PAULO. Relatório Anual Apresentado ao Exmo Snr Dr Jorge Tibiriça M. D. Secretário da Agricultura pelo engenheiro chefe João Pereira Ferraz, 1894, pp 44 a 47.
} 
6.325 Barricas de cimento de Santana ao Ramal do Bispo

100 Barras de chumbo da Ponte Pequena a Cantareira

6 Barras de chumbo de Santana ao Ramal do Bispo

1.470 Barricas de cimento da Ponte Pequena a Cantareira

883 Barricas de cimento da Ponte Pequena ao Ramal do Bispo

2.213 Barricas de cimento da rua João Teodoro à Ponte Pequena

3.636 Barricas de cimento de Santana a Cantareira

3.636 Barricas de cimento de Santana a Cantareira

4 Canos de $200 \mathrm{~mm}$ da Ponte Pequena a Cantareira

26 Canos de $200 \mathrm{~mm}$ de Santana ao Ramal do Bispo

1.140 Canos de $300 \mathrm{~mm}$ da Ponte Pequena a Cantareira

259 Canos de $300 \mathrm{~mm}$ da Ponte Pequena ao Mandaqui

394 Canos de $300 \mathrm{~mm}$ da Ponte Pequena ao Ramal do Bispo

549 Canos de $300 \mathrm{~mm}$ de Santana a Cantareira

188 Canos de $300 \mathrm{~mm}$ de Santana ao Ramal do Bispo

23 Canos de $600 \mathrm{~mm}$ de Santana a Cantareira

97 Canos de $600 \mathrm{~mm}$ de Santana ao Ramal do Bispo

180 Canos de barro de $200 \mathrm{~mm}$ de Santana a Cantareira

3 Curvas de barro de $300 \mathrm{~mm}$ de Santana a Cantareira

16.300 Metros cúbicos de pedra de Tremembé à Ponte Pequena

222 Metros cúbicos de terra de Santana à Ponte Pequena.

2 Registros ed de $300 \mathrm{~mm}$ da Ponte Pequena a Cantareira

168.083 Tijolos de Santana ao Ramal do Bispo

94.840 Tijolos do Ramal do Bispo a Cantareira

3 Virolas $^{186}$ de Santana a Cantareira

3 Virolas de Santana ao Ramal do Bispo

${ }^{186}$ Aro metálico que reforça um objeto e às vezes serve também como ornamento. 
No segundo semestre:

Tijolos

Telhas

Canos de ferro

Ditos de barro

Cimento barricas
277.964

1.900

1.739

20.048

6.306

Além destes materiais, foram transportados outros, que só puderam ser classificados pelo peso:

Carvão

Areia

Madeira

Mudança de ranchos

Trens facultativos

Trens especiais

Pessoal de trabalhadores
9.000 kilos

63.000 kilos

51.000 kilos

12.000 kilos

2.922.000 kilos

572.000 kilos

450 kilos

Neste primeiro ano a renda bruta chegou a 2:135\$200, sendo:

Viajantes

Mercadorias

Bagagem

Passes livres
$1: 369 \$ 900$

$235 \$ 800$

$153 \$ 500$

$376 \$ 000$

Foram transportados 1577 passageiros, além de 51, que transitaram a serviço do próprio tramway.

Constava como material rodante: 4 locomotivas:

1 Locomotiva americana de 13 toneladas com um tender

2 Locomotivas inglesas de 13 toneladas com tender

1 Locomotiva de 8 toneladas inglesa com tender

2 Vagões americanos com compartimento fechado e envidraçado no centro 


\section{Vagões abertos para passageiros}

\section{Vagões para bagagem}

5 Vagões plataformas para condução de tubos

3 Vagões com taipais para lastro

6 Vagões tipo plataformas

6 Vagões americanos para 8.000 quilos de carga

6 Troles para o serviço de linha

Segundo o responsável pelo tramway, com relação ao material rodante, os que apresentaram melhor resultado, com relação a segurança, comodidade e economia na manutenção, foram os dois carros de passageiros com compartimento no centro e a locomotiva americana.

Não consta o carregamento de pedras com destino à serra, porém, este material, é a base de construção de todos os reservatórios de $1894^{187}$. As rochas para as obras foram retiradas do próprio local, como pode ser visto no detalhe nas fotos abaixo:

\footnotetext{
${ }^{187}$ Por ato de 09 de Abril de 1893, foi permitido que na tabela das tarifas do tramway o transporte de pedras tinha o abatimento de $25 \%$ de frete estipulado para as forragens produzidas no Estado. No entanto, como o desconto foi solicitado pelo Chefe da Comissão de Saneamento e não pelo Pereira Rebouças, talvez esse material fosse apenas para as obras de aterro da várzea do Tamanduatei e do Tietê. Segundo o ........ O serviço de transporte de materiais para as obras de canalização na serra, iniciado a 9 de Novembro de 1893, continuou com regularidade durante o anno próximo pretérito. Para melhor attender o transporte desses materiais e da pedra que se havia de empregar na ponde da Avenida Tiradentes, construiu se o ramal de cerca de $400 \mathrm{~m}$ de extensão, que ao mesmo tempo serviu para o transporte dos materiais destinados a serra. In Relatório da Secretaria dos Negócios da Agricultura, Commercio e Obras Publicas do Estado de São Paulo apresentado em 3 de Março de 1895 ao Dr Bernardino de Campos Presidente do Estado de São Paulo pelo Jorge Tibiriça, Secretario de Estado, São Paulo, Typ. Paulista, 1895
} 


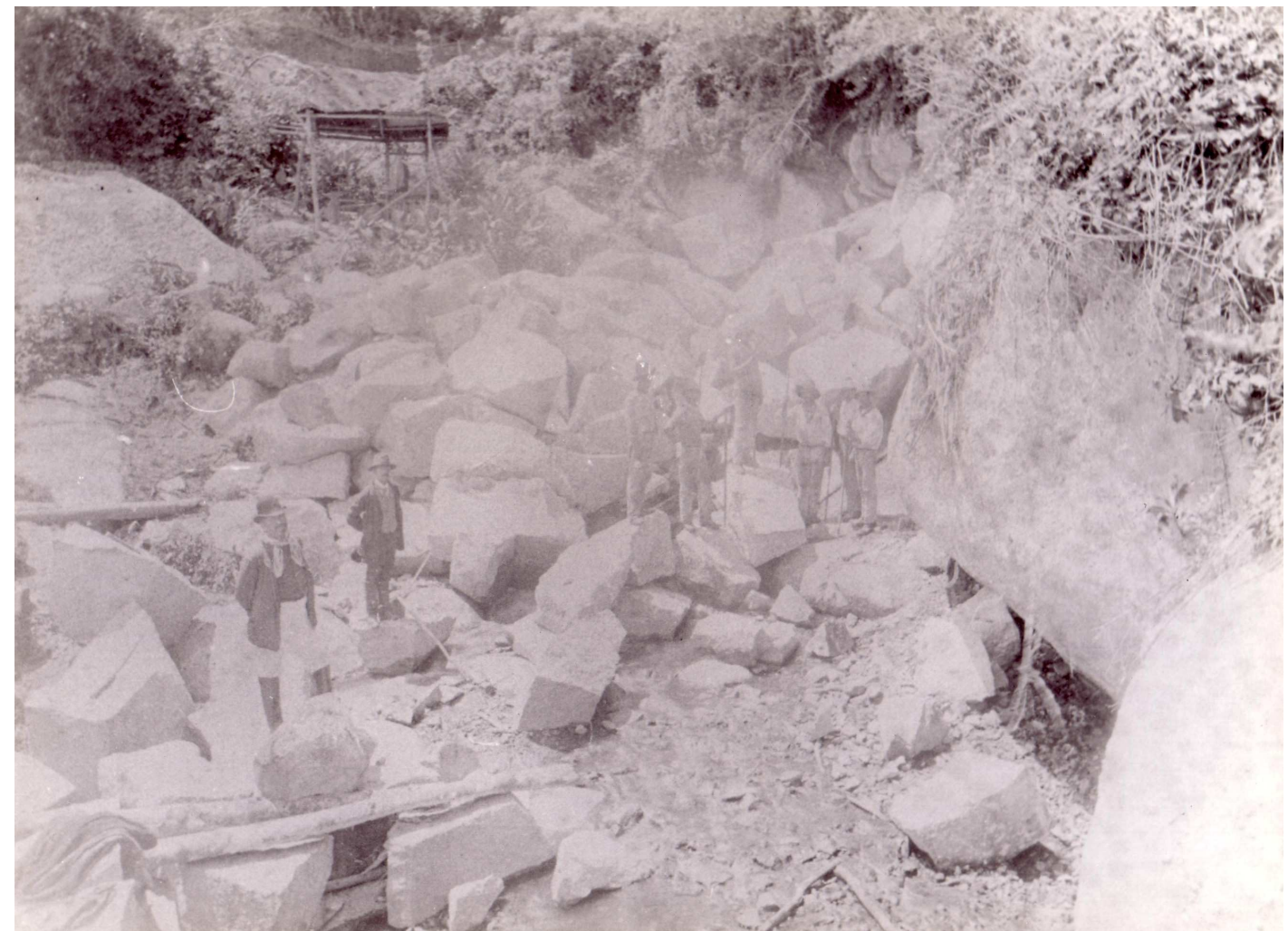

Construcção da Represa do Ytaguassu Foto: P. Doumet 1893 Acervo Arquivo do Estado de São Paulo. Obs. à esquerda o engenheiro José Pereira Rebouças, responsável pela obra.

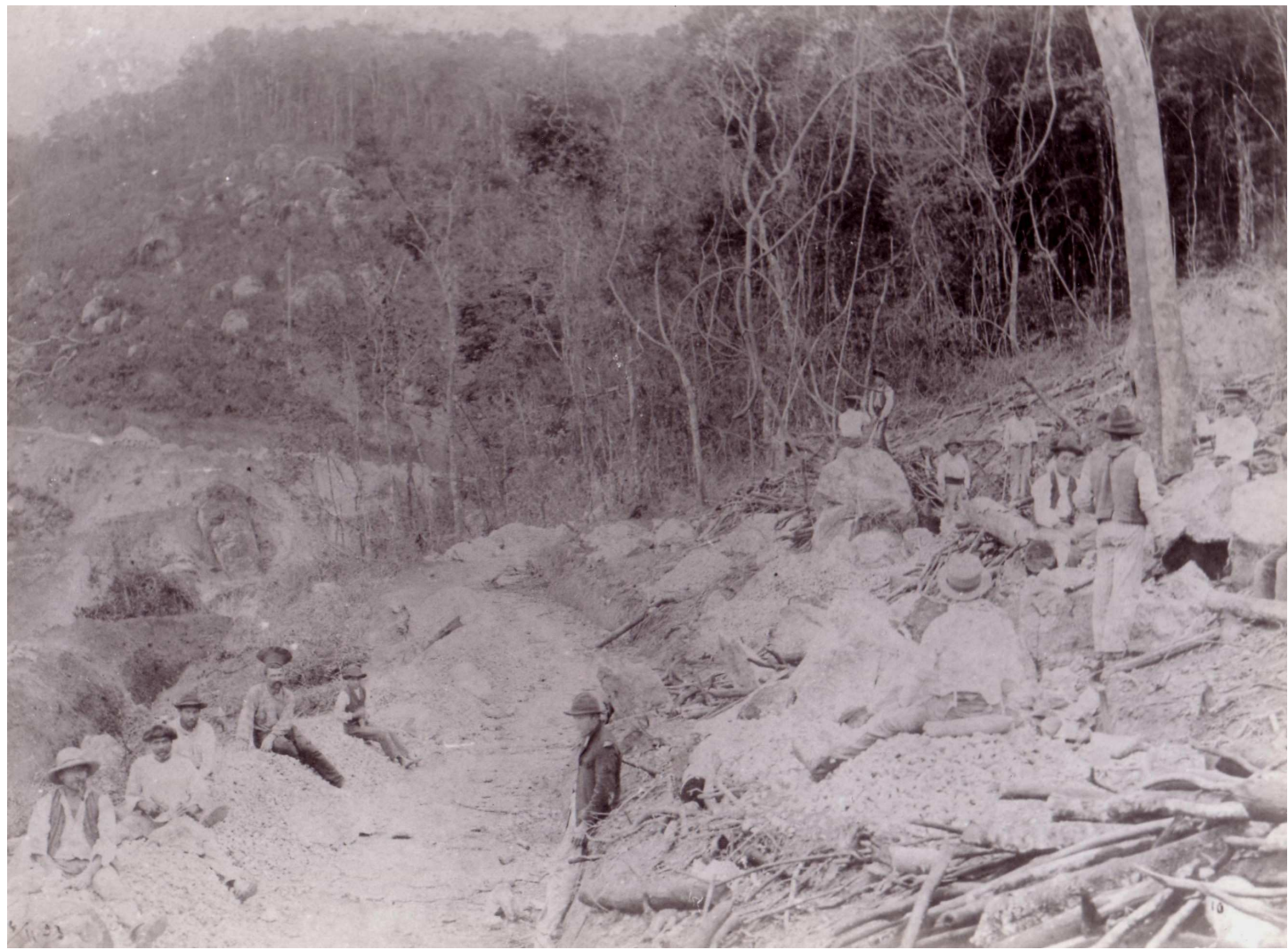

Quebramento de pedras para o concreto Foto P. Doumet 1893 Acervo Arquivo do Estado de São Paulo 
Confirmando essa assertiva, em 1894, a Comissão de Saneamento mandou construir um ramal provisório de $400 \mathrm{~m}$ de extensão, para trazer pedras da Cantareira para as obras das pontes sobre os rios Tietê e Tamanduateí.

Em 1965, com a desativação do tramway, as edificações ferroviárias ao longo do seu leito, foram demolidas, restando apenas, a Estação do Reservatório de Acumulação.

Parte integrante da nova configuração da vida, e do imaginário da população paulistana, deixou traços indeléveis na paisagem urbana, na cultura popular, nos nomes das ruas e praças, estabelecimentos comerciais e nas constantes exposições de fotografias daquela época, onde carinhosamente ainda é lembrado como o trenzinho da Cantareira.

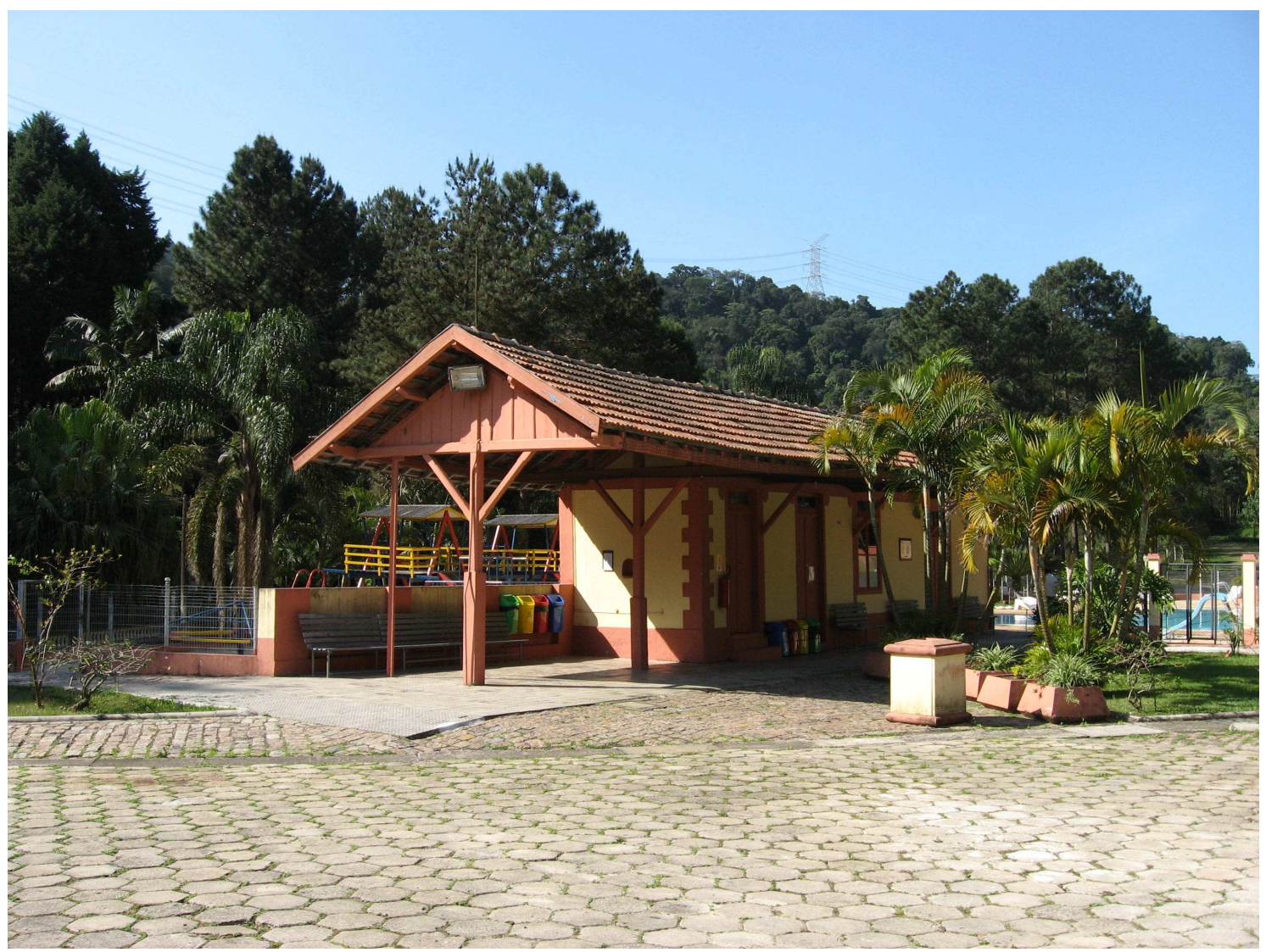

Estação terminal do Tramway Outubro de 2007 


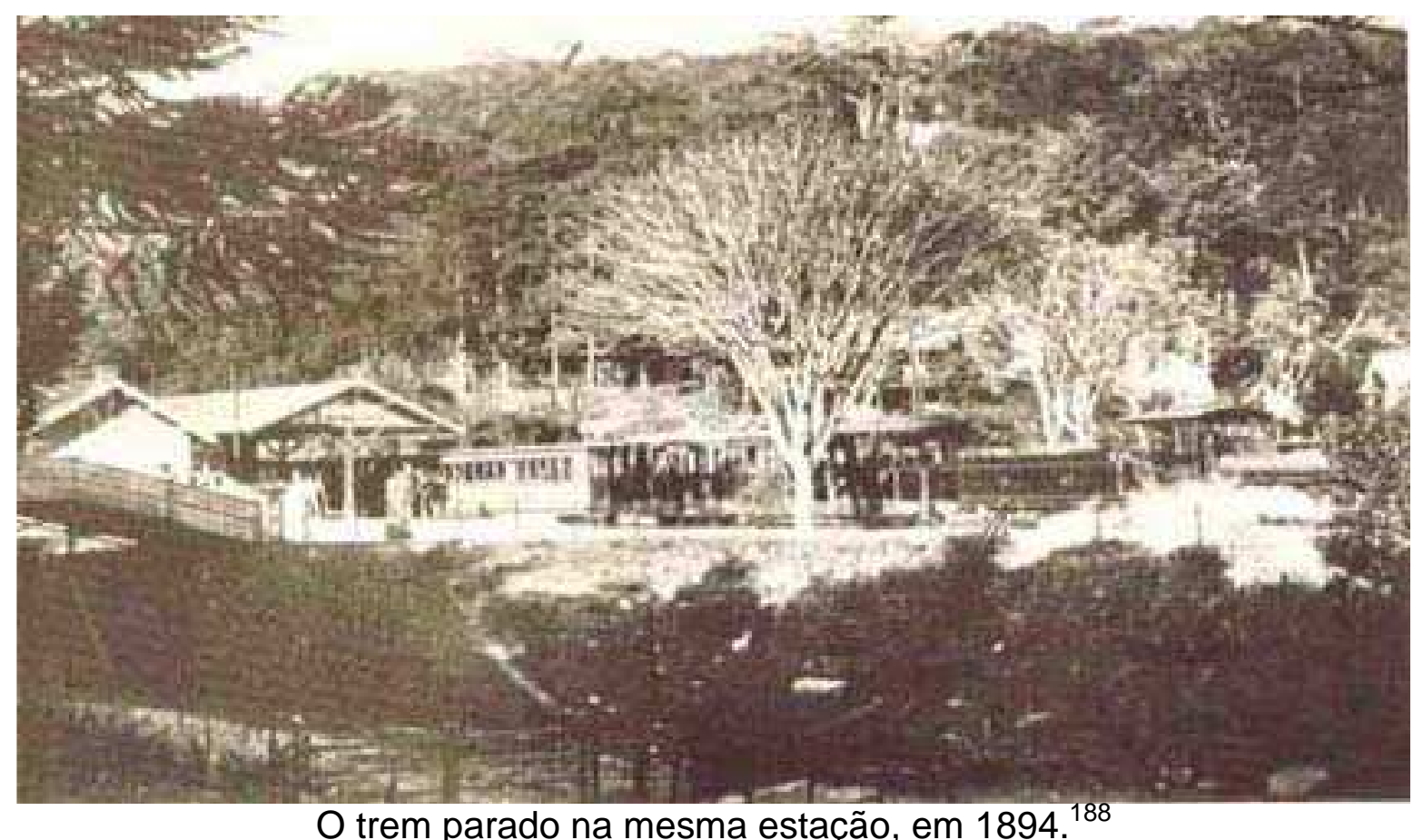

${ }^{188}$ CORREA, Dora, ALVIM, Zuleika. M. F. A água no olhar da História, São Paulo, Secretaria do Meio Ambiente, 1999, p. 117. 


\subsection{Captação - Obras urbanas}

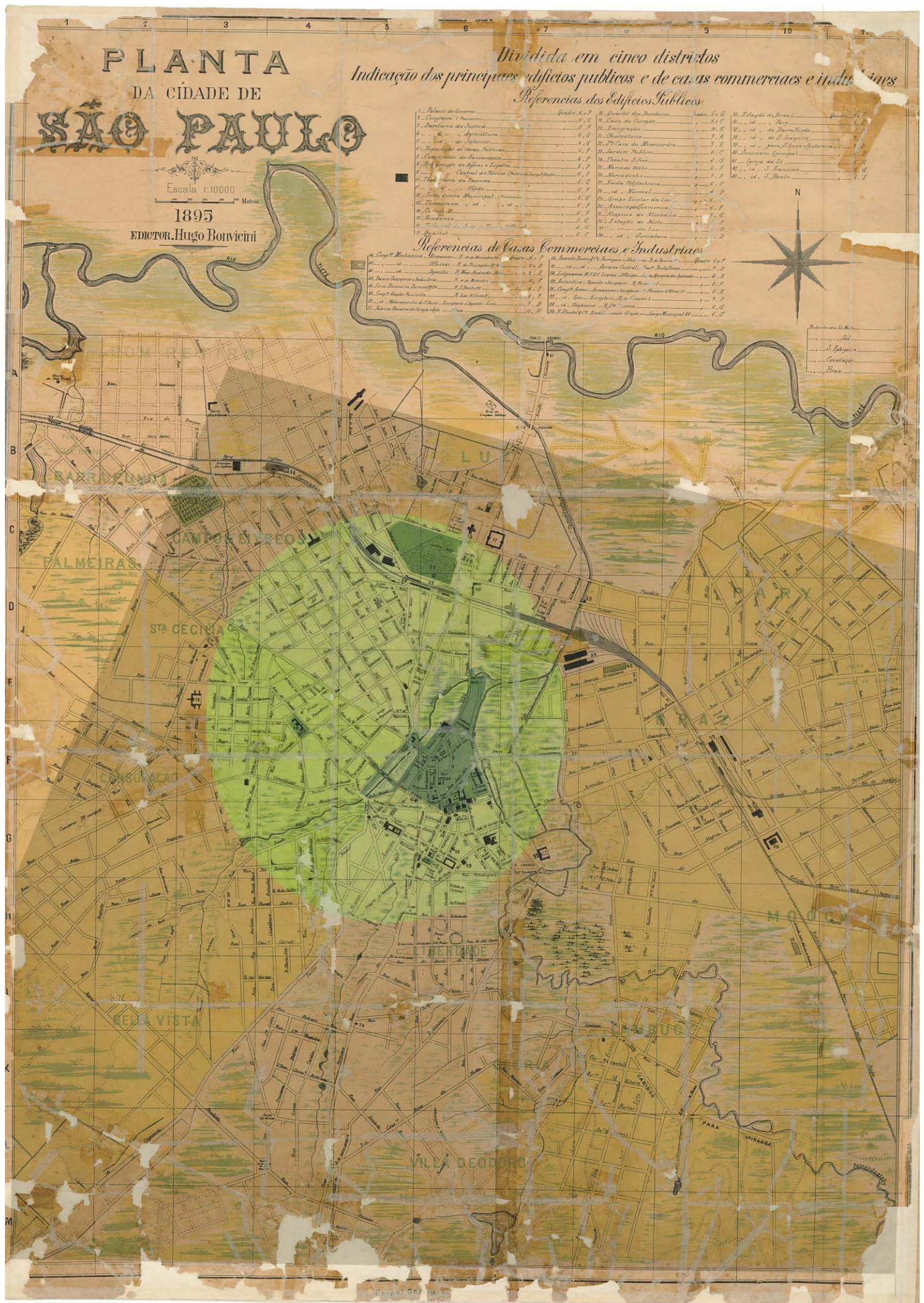

Em verde: 1877 a 1892 - abastecimento de água pela Companhia Cantareira Em destaque: 1893 e 1894 - ampliação da rede pela RAE 
Em 1898, as águas que abasteciam a cidade vinham de dois locais, da Serra da Cantareira e do ribeirão Ipiranga.

Da serra desciam três linhas adutoras para os reservatórios de distribuição no alto da cidade. Da região do Campo Redondo e do Engordador, chegavam à cidade duas linhas de 280 e 300 milímetros de diâmetro, conduzindo sete milhões de litros para o reservatório da Liberdade e para o abastecimento direto da zona alta da cidade.

Do Reservatório de Acumulação e da região do Guaraú saia o encanamento de 600 milímetros, transportando vinte milhões de litros para o Caixa d'Água da Consolação.

Em condições normais, os reservatórios da cidade armazenavam trinta milhões de litros, e os encanamentos adutores podiam distribuir água diretamente, lançando na rede geral, trinta e um milhões diários, somando-se com a quantidade armazenada, poderia chegar a sessenta e um milhões a capacidade de água, a ser distribuída, somente da Serra da Cantareira.

$\mathrm{Na}$ época das chuvas, esse volume ganhava a contribuição de quatro milhões diários do ribeirão Ipiranga, elevando o suprimento a 65 milhões em 24 horas, sendo o provimento em dias normais de aproximadamente trinta e quatro milhões. Deve-se ressaltar que o Ipiranga chegava a ter vinte e quatro milhões de litros nos períodos chuvosos, mas somente a sexta parte podia ser aproveitada, uma vez que, além da canalização de 300 milímetros limitar a sua distribuição, as represas não desaguavam em um reservatório de acumulação.

Tabela de Capacidade de Distribuição

\begin{tabular}{|c|c|c|c|c|}
\cline { 2 - 5 } \multicolumn{1}{c|}{} & $\begin{array}{c}\text { Condições } \\
\text { Normais }\end{array}$ & Estiagem & $\begin{array}{c}\text { Período de } \\
\text { Chuvas }\end{array}$ & $\begin{array}{c}\text { Capacidade do } \\
\text { Encanamento }\end{array}$ \\
\hline $\begin{array}{c}\text { Sistema } \\
\text { Cantareira }\end{array}$ & 27.000 .000 & 15.000 .000 & 53.000 .000 & 31.000 .000 \\
\hline Ypiranga & 4.000 .000 & 347.000 & 24.000 .000 & 4.000 .000 \\
\hline
\end{tabular}

Os mananciais na serra sofriam com problema semelhante, embora com encanamento de 600 milímetros, este restringia a distribuição, uma vez que, nos 
meses chuvosos o volume podia atingir 53.000 .000 mas $40 \%$, não eram aproveitados.

Nos períodos de estiagem essas condições sofriam um revés. Os mananciais da Cantareira desciam a 15 milhões de litros diários. $O$ abastecimento pelo Ipiranga chegava ao mínimo de 347.000 litros.

Os reservatórios da cidade amanheciam com menos da metade de sua capacidade, e muitas vezes chegavam a 3.000 .000 de litros, ou seja, apenas um décimo de sua real capacidade.

De Julho a Agosto e até mesmo em Setembro, o abastecimento da cidade ficava reduzido ao extremo limite de 18.000 .000 de litros, ou menos de um terço do volume ordinário acusado nos períodos de chuvas.

Abastecimento de água em 24 horas

\begin{tabular}{|c|c|c|c|c|c|}
\hline Ano & $\begin{array}{c}\text { Órgão } \\
\text { Responsável }\end{array}$ & Captação & $\begin{array}{c}\text { Abastecimento } \\
\text { (L) }\end{array}$ & População & $\begin{array}{c}\text { Litro } \\
\text { (Per } \\
\text { capta) }\end{array}$ \\
\hline 1870 & $\begin{array}{c}\text { Poder } \\
\text { Público } \\
\text { Estadual e } \\
\text { Municipal }\end{array}$ & $\begin{array}{c}\text { Tanque Reúno } \\
\text { Tanque Municipal }\end{array}$ & 109.780 & 30.000 & 3,5 \\
\hline 1881 & $\begin{array}{c}\text { Cia. } \\
\text { Cantareira }\end{array}$ & $\begin{array}{c}\text { Serra da } \\
\text { Cantareira:Reservatórios } \\
\text { de Acumulação }\end{array}$ & 3.000 .000 & 30.870 & 97 \\
\hline 1892 & $\begin{array}{c}\text { Cia. } \\
\text { Cantareira }\end{array}$ & $\begin{array}{c}\text { Serra da Cantareira: } \\
\text { Reservatórios de } \\
\text { Acumulação }\end{array}$ & 3.000 .000 & 120.000 & 223 \\
\hline $\begin{array}{c}\text { RAE - } \\
\text { Repartição } \\
\text { de Águas e } \\
\text { Esgotos }\end{array}$ & $\begin{array}{c}\text { Serra da Cantareira: } \\
\text { Reservatórios de } \\
\text { Acumulação e Represas } \\
\text { da Cuca ao Engordador } \\
\text { e } \\
\text { Ribeirão Ypiranga }\end{array}$ & 27.000 .000 & 140.000 & 2.000 .000 & \\
\hline
\end{tabular}

Para solucionar o problema, os engenheiros da então Repartição de Águas e Esgotos não quiseram modificar os encanamentos, preferindo o que parecia ser uma solução mais fácil, isto é, abrir três poços artesianos na margem direita do rio Tamanduateí, o que foi feito pela RAE em Abril de 1894.

Em Outubro daquele ano depois de adquirir o material necessário procederam à escavação do primeiro poço. Em Dezembro já haviam perfurado 80 metros, porém, quando atingiram a profundidade de 100 metros encontraram uma camada rochosa que impedia a continuação dos trabalhos, e os gastos inviabilizaram o segundo 
poço, projetado para ser aberto na rua do Gasômetro em solo que à primeira vista parecia ser mais promissor .

Em 1897 a cidade atingia 230.000 habitantes exigindo um suprimento diário de trinta milhões de litros, ou 130 litros por habitante. Neste ano a estiagem reduziu os mananciais da Serra da Cantareira em 15.000 .000 de litros, tendo o ribeirão Ipiranga atingido o mínimo de 347.000 litros, ou seja, uma redução de $50 \%$, o que causou uma grave crise no abastecimento.

Para resolver a situação, foi necessário recorrer a várias medidas visando garantir maior fornecimento ao bairro do Brás, que por sua posição topográfica e dependência da rede distribuidora, se constituía em elemento desestabilizador do sistema.

Em caráter experimental, resolveram captar as águas do rio Tietê na altura do Belenzinho, onde o rio corria rápido sobre leito arenoso. Para isso, instalaram 701 metros de encanamento de ferro de $300 \mathrm{~mm}$, desde o extremo da rede de distribuição, até a margem do rio e para elevar as águas, instalaram uma bomba a vapor. Foi implantada uma galeria filtrante, em forma de túnel, de 8 metros abaixo do leito do rio, com a capacidade para filtrar mais de dois milhões de litros. Após o término das obras, chuvas torrenciais adiaram o abastecimento com esse sistema. De acordo com a documentação, do período até o ano de 1900 estas águas não tinham sido utilizadas. 
5 CONVERGINDO PARA A ARQUEOLOGIA DA SERRA DA CANTAREIRA

\subsection{Um arquivo do passado}

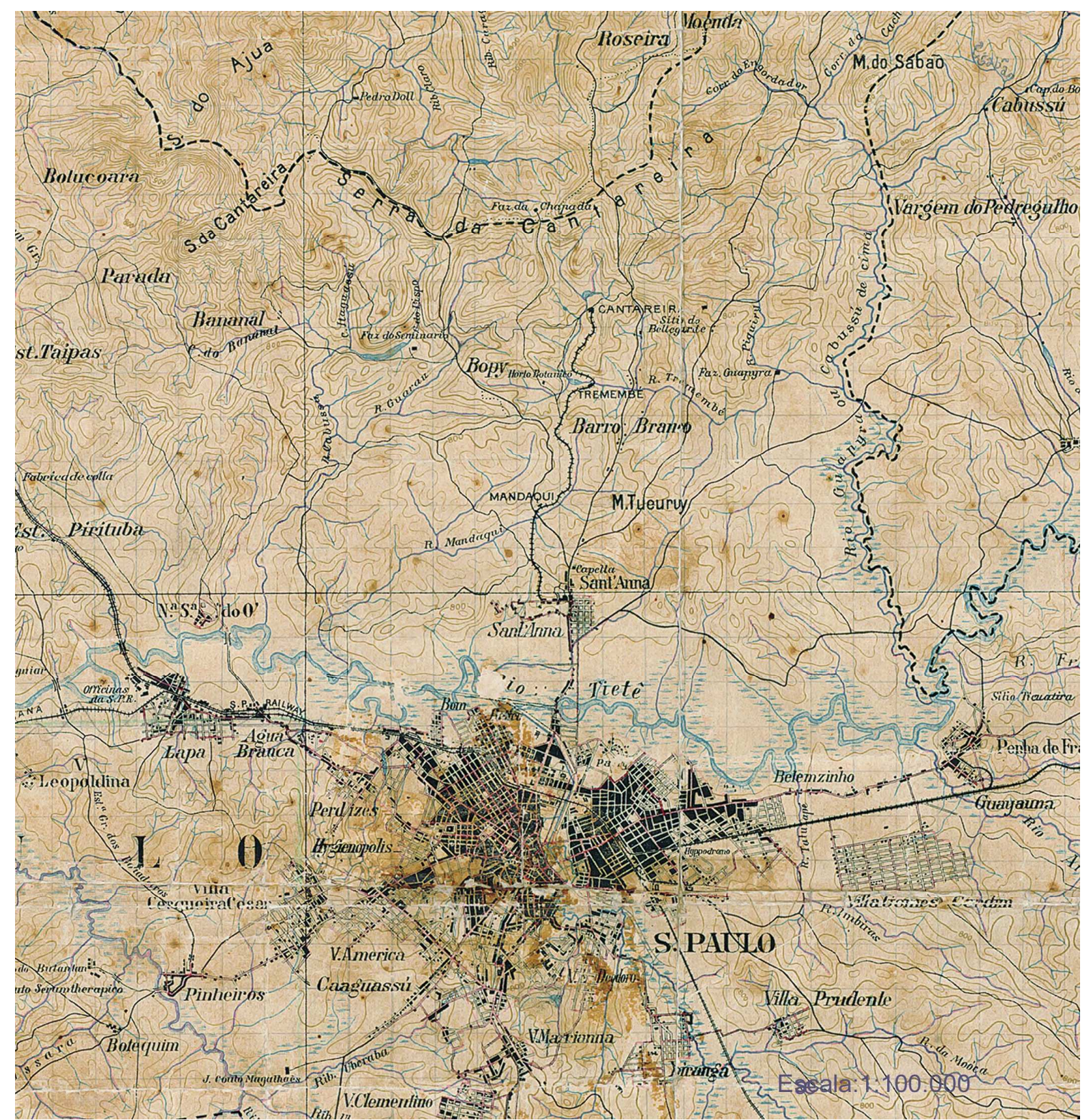

Rede de drenagem em 1904, com o rio Tietê sem retificação.Comissão Geográfica e Geológica - Publicação Especial para a Secretaria da Justiça e Segurança Pública Folha do Município da Capital. Escala 1:100.000 Acervo do Instituto Geográfico e Cartográfico. 


\subsection{Um arquivo do passado}

O Parque Estadual da Cantareira, está situado praticamente a $14 \mathrm{Km}$ em linha reta do centro da cidade, na Zona Norte da Capital paulistana, de maneira que é facilmente acessível através de transporte coletivo. Sua área é cortada por quatro estradas asfaltadas, a BR 381, Fernão Dias, ligando São Paulo a Belo Horizonte; a Avenida Coronel Sezefredo Fagundes; a Estrada de Santa Inês e a Avenida Senador José Ermírio de Moraes.

A rede de drenagem é em padrão dentrítico, com orientação sul, no inverno há um rebaixamento no nível de água. Os cursos são perfeitamente estabilizados, margeados por vegetação arbórea, apresentando, todavia, poucas quedas d'água (cachoeiras). ${ }^{189}$ (NEGREIROS, 1974)

Segundo Mendes, por mais abundante que seja a informação em outras fontes, nada deve substituir a observação direta, "in loco", do sítio, das estruturas, tecnologia, etc

Para esse autor, a Arqueologia Industrial deve, ao pesquisar obras de construção civil, como é o caso do abastecimento de água, ampliar o:

(...) objecto de estudo, contemplando as suas múltiplas vertentes. Assim, perante determinada estrutura, além de uma análise cuidada do que ela ainda apresenta de forma visível, procura responder:

A quem deveu a decisão de efectuar a obra, quais os objectivos? Autor do projecto e/ou empresa, construtor, materiais utilizados, características, origem, transporte e a técnica utilizada na construção. Partindo sempre dos vestígios materiais com a complementaridade das fontes escritas e iconográficas. ${ }^{190}$ (MENDES, 1996)

\footnotetext{
${ }^{189}$ NEGREIROS, Osmar C. de et al, Plano de Manejo para o Parque Estadual da Cantareira. São Paulo, Boletim Técnico do Instituto Florestal no 10, 1974, p. 12.

${ }_{190}$ MENDES, J. Amado. Construção Civil e Patrimônio Industrial. In Revista Munda no 31, Coimbra, 1996, p 34,35.
} 
Para os historiadores da cultura material, aí incluídos os arqueólogos que investigam sociedades históricas (tal é o caso, por exemplo, da arqueologia industrial), sobre as quais existem inúmeros outros elementos além daquelas coisas materiais que nos chegaram, tais coisas não são abordadas naquele aspecto de evidências de que houve uma dada cultura em algum tempo e lugar, pois não é a constatação dessa existência que está em questão, já que sobre isso não há dúvidas. O valor dessas expressões materiais está em permitir a compreensão de fenômenos culturais dos quais elas são OS vetores mais eloqüentes. ${ }^{191}$ (BARBUY, 2006)

A rede de distribuição de água para uso público e residencial é a parte menos visível dos equipamentos coletivos de uma cidade. No caso de São Paulo, com exceção dos reservatórios da Consolação e da Liberdade, que estão inseridos na paisagem urbana, a infra-estrutura que envolve todo esse sistema, como, represas, pontes aquedutos e reservatório de Acumulação, se encontra a catorze quilômetros da urbe, na então distante Serra da Cantareira.

Os Reservatórios de Acumulação foram construídos logo após a fundação da Companhia Cantareira, em 1877. Em 1893, quando a empresa foi encampada pelo governo, a Superintendência de Obras reformou os antigos reservatórios e no mesmo ano, captou as águas do manancial do Cassununga, e, em seguida, ampliou a infraestrutura com a construção das represas da, Cuca, Canivete, Depósito, Manino, Ytaguassu, Olaria, Guaraú e Engordador, segundo projeto do engenheiro José Pereira Rebouças.

A partir de 1973, todo esse complexo foi sendo desativado, quando entrou em operação, o moderno sistema de abastecimento de água da Cantareira.

As matas do Parque Estadual da Cantareira em virtude de sua função protetora de mananciais e do solo, são consideradas de Preservação Permanente por efeito do artigo $2^{\circ}$ do Código Florestal. Por outro lado, são consideradas como de domínio do próprio Instituto Florestal, a vista do item III, do artigo $2^{\circ}$, Seção I, do Decreto Estadual no 52.370, de 26 de janeiro de 1970, que estabelece que o Instituto Florestal deve "intervir no setor florestal, detendo o domínio das florestas de preservação permanente". ${ }^{192}$

\footnotetext{
${ }^{191}$ BARBUY, Heloisa, A Cidade-Exposição Comércio e Cosmopolitismo em São Paulo, 1860 - 1914. São Paulo, EDUSP, 2006, p. 24.

192 NEGREIROS, Osmar C. de et al, Plano de Manejo para o Parque Estadual da

Cantareira. São Paulo, Boletim Técnico do Instituto Florestal no. 10, 1974, p.22.
} 
Em 04 de agosto de 1983, a Resolução 18, o CONDEPHAAT, através da Secretaria da Cultura em seu artigo 10: "Fica tombada a área da Reserva Estadual da Cantareira (...."193

Em 1994, o Programa MaB - Man and Biosphere da UNESCO, declarou o Parque Estadual da Cantareira "como área integrante da Reserva da Biosfera do Cinturão Verde da Cidade de São Paulo, com status de Patrimônio da Humanidade.

\subsection{Traduzindo o modelo em inventário}

\subsubsection{Patrimônio Industrial}

“(...) só se pode conservar aquilo que se conhece ....". 194 "(...) podemos acrescentar que, só se conserva ou pode conservar aquilo que se quer, ou melhor, aquilo que o poder instituído, conhece e quer"... ${ }^{195}$

Constituem o patrimônio industrial os chamados monumentos industriais. Segundo MENDES ${ }^{196}$ : podemos distribui-los em três grandes grupos:

Vestígios referentes à produção artesanal e industrial, entre os quais se incluem: oficinas, estruturas fabris e habitacionais como os bairros operários; ferramentas e utensílios, maquinário,moldes, produtos,catálogos, meios de transmissão de energia e de iluminação.Essa cultura material deve ser estudada em interligação com os fatores humanos e sociais, os ritmos de produção, concentração e condições de trabalho, sindicalismo, cultura operária, associações culturais e sua atuação.

Transportes e comunicações cujo elemento mais significativo foram, sem dúvida, as estradas de ferro, que no caso específico da capital paulistana, a partir de 1864, com a inauguração da São Paulo Railway, a teve uma ocupação espacial e habitacional sem precedentes;

193 SÃO PAULO. Leis e Decretos, Resolução 18, de 04 de agosto de 1983. O Secretário Extraordinário da Cultura, nos termos do artigo $1^{\circ}$ do Decreto-lei 149 , de 15 de agosto de 1969 e do Decreto 13.426, de 16 de março de 1979, resolve: Fica tombada a área da Reserva Estadual da Cantareira e Parque Estadual da Capital (Horto Florestal), gerenciada pelo Instituto Florestal.

${ }_{194}$ MARQUES, T. O conceito de carta arqueológica a partir da experiência portuguesa, Vipasca, №02,1993, p.118.

195 QUINTEIRA, A. J. F. Breve comentário sobre o património, Revista Munda no 33, Coimbra, Portugal, 1997, p.56.

${ }_{196}$ MENDES,J. A. Património Industrial: um bem da comunidade ao alcance da escola in Revista Munda ํㅡ 20, Coimbra, Portugal, 1990, p. 68-69. 
Os equipamentos coletivos referentes ao abastecimento e distribuição de energia, hidráulica, eólica, a gás e elétrica; estruturas relativas ao abastecimento de bens, mercados, armazéns, saneamento e abastecimento de água.

CUSTÓDIO afirma: "Durante o século XIX, a constante subversão dos ritmos econômicos sociais e tecnológicos estendia-se ao mundo urbano, aos equipamentos coletivos e à própria vida quotidiana." ${ }^{197}$

Assim, o patrimônio industrial abrange além das fábricas e oficinas, com tudo o que as caracteriza, instalações, tecnologia,localização, área do entorno, incluindo as técnicas, matérias primas e produtos industrializados; registros escritos, orais, iconográficos; meios de comunicação e de transporte; fontes e distribuição de energia; paisagens industriais e obras públicas. ${ }^{198}$

Como os diversos componentes do patrimônio industrial fazem parte do nosso cotidiano, estão em permanente processo de renovação.

A rápida transformação tecnológica que se verifica nos últimos anos, se por um lado aumenta o número de elementos do patrimônio industrial, por outro, contribui para a destruição e o desaparecimento de parte considerável do mencionado patrimônio". ${ }^{199}$ (DELAUNAY, 1987)

Urge que se tome medidas para refrear esta destruição, chamando a atenção para as potencialidades da nossa herança industrial, cabendo à Arqueologia industrial, o seu estudo e salvaguarda.

A história passa também pelo cotidiano: pelos encanamentos, por pontes e aquedutos, reservatórios de água, pelas habitações simples, pelos veículos de serviço, pelas máquinas e utensílios - e não somente pelo que pertenceu e foi concebido por uma elite restrita, isto é, fortes, pelourinhos e igrejas barrocas. $O$ patrimônio cultural integra muitas outras realidades, cuja salvaguarda e preservação é de nossa responsabilidade para que sejamos dignos do legado cultural que herdamos e simultaneamente, para podermos transmitir esse patrimônio para as futuras gerações.

\footnotetext{
${ }^{197}$ CUSTODIO, J. Arqueologia Indústria e Patrimônio in História e Crítica, Lisboa, №5, maio de 1980.

${ }^{198}$ MENDES, A. Inventariação do Património Industrial in Revista Munda oㅜ 16 Coimbra, Portugal, 1988 , p. 45

199 DELAUNAY, C. Aspects of Council of Europe Action,. The Industrial Heritage: What Policies?, Council of Europe, Architectural Heritage and Studies, $\stackrel{0}{06}$, Estraburgo, 1987, p. 7
} 
Segundo a Carta de Nizhny Tagil : "O Patrimônio Industrial compreende os vestígios da cultura industrial que possuem valor histórico, tecnológico, social, arquitetônico e científico."200

\subsubsection{Haverá futuro para o passado ${ }^{201}$}

Para se estudar o patrimônio industrial deve-se considerar os equipamentos coletivos criados em função da indústria e de uma lógica de sociedade em processo de industrialização como é o caso da São Paulo do final do século XIX. Implantados pelo Estado numa imagem idealmente utópica de cidade e divulgados com uma visão falsamente paternalista de bem comum que favoreceria a todos os paulistanos.

Este tipo de patrimônio é ainda mais difícil de ser estudado do que as unidades de produção, não só devido à sua especificidade construtiva, mas também porque integram um conjunto de equipamentos que são vistos principalmente como economicamente improdutivos. Esses vestígios industriais constituem um patrimônio de alto risco, na medida que são mais vulneráveis às demolições.

Enquanto as fábricas tiveram, de uma maneira geral, um crescimento organizacional definido em padrões de proximidade, por razões que se prendem com a própria produção, como as vias para escoar seus produtos ou a facilidade de acesso dos operários, instalando-se nas antigas periferias. As diversas obras públicas, como é o caso do abastecimento de água, encontram-se disseminadas na área urbana e rural. Justamente essa diversidade revela o nível de complexidade em contextualizá-los.

A urgência e a primazia em realizar um programa de inventário relacionam-se diretamente com o grau efêmero ou perene do próprio patrimônio. ${ }^{202} \mathrm{O}$ estudo e a identificação deste tipo de vestígio arqueológico principalmente na área urbana é ainda mais difícil de se efetuar uma vez que muitas das ameaças que geralmente

\footnotetext{
200 Carta de Nizhny Tagil sobre o Património Industrial. The International Committee for the Conservation of the Industrial Heritage TICCIH. Tradução de José Manuel Lopes Cordeiro, 2003

${ }^{201}$ QUINTEIRA, A. J. F. Breve comentário sobre o património, Munda, oㅡ 33, Coimbra, Portugal, 1997,

p. 51 TROTTIER, Rapport (org) Le patrimoine industriel au Québec - État de la Situation et Recommandations Commission des biens culturels du Québec, 1987 p17
} 
afligem o equipamento coletivo quando desativado já ocorreram, tornando improrrogável um inventário desta natureza. ${ }^{203}$

\begin{abstract}
A implantação de um projeto científico que analise questões envolvidas com a Arqueologia Industrial, requer, em um primeiro momento, a elaboração de um inventário, com localização e o estado de conservação dos pólos e dos momentos industriais, a fim de que se possa proceder ao seguinte, que é a catalogação destes sítios e seus componentes, através de técnicas arqueológicas de resgate e documentação da cultura material. Somente a partir daí, é que poderemos falar em salvaguarda e valorização deste patrimônio, transformando-o em objeto de estudo a ser inserido no contexto da História Local." ${ }^{204}$ (LOTUFO, 1991)
\end{abstract}

Como esse tipo de inventário ainda é inédito em São Paulo, na medida do possível, foi procurada orientação metodológica em outros modelos já realizados em outras cidades, aplicando critérios de análise respeitando as especificidades inerentes a cada realidade.

Quase todas as experiências de inventários industriais consultados utilizam fichas de levantamento diferenciadas, de acordo com o entendimento da noção de patrimônio, existente no momento de sua elaboração, com exigências mais direcionadas para uma ou outra temática ou para um tipo de indústria específica, porém, não contemplando os equipamentos coletivos. ${ }^{205} \mathrm{~A}$ análise de toda esta produção estará patente no modelo realizado de inventário da herança da água no final do século XIX.

No âmbito deste estudo, entende-se por inventário do patrimônio industrial da infraestrutura do abastecimento de água, a seleção, a identificação, a caracterização e a contextualização dos vestígios que reúnem em si os atributos que justifiquem a sua inventariação. Há uma pretensão sublimada no ato de seleção e registro: a sua proteção.

A elaboração de um conjunto de fichas, instrumento fundamental para a tarefa proposta tem algumas preocupações subjacentes.Um dos objetivos estabelecido prende-se com a criação de um documento de registro o mais universal possível,

\footnotetext{
${ }^{203}$ LES INVENTAIRES DU PATRIMOINE INDUSTRIEL - Industrial Heritage Inventories, Actes des colloques de la Direction du Patrimoine, França, 1986.

204 LOTUFO, C. L. Os Primórdios da industrialização no Município de Engenheiro Frontin - RJ, Munda, no 22, Coimbra, Portugal, p. 107.

${ }^{205}$ L'ÉTUDE ET LA MISE EN VALEUR DU PATRIMOINE INDUSTRIEL 4ª Conférence internationale Lyon - Grenoble, 1985. p 28.
} 
tendo em conta as diversidades que o objeto de análise encerra, de modo a viabilizar sua utilização por outros pesquisadores em outros modelos de inventários.

Em 1992, a preocupação com a diversidade de modelos, levou os especialistas em patrimônio a se reunirem, na cidade de Nantes em colóquio organizado pelo Conselho da Europa e o Ministério Francês da Educação e Cultura, para discutirem um mecanismo que possibilitasse um intercâmbio de dados.

Decidiu-se que os inventários deverão ter uma ficha de conteúdo mínimo e independentemente dos objetivos, critérios e métodos, deverão responder:

1. Designação

2. Localização

3. Função original

4. Uso atual

5. Data da Construção

6. Materiais utilizados

7. Tipo de proteção legal

A Carta de Nizhny Tagil sobre o Patrimônio Industrial elaborada em 2003, pelo The International Comittee for the Conservation of the Industrial Heritage TICCIH, entidade vinculada ao ICOMOS em seu capítulo III da importâcia da identificação, do inventário e da investigação recomenda:

"1. Todas as coletividades territoriais deveriam identificar, inventariar e proteger os vestígios industriais que pretendem preservar para as futuras gerações;

2. Os levantamentos de campo e a elaboração de tipologias industriais deveriam permitir conhecer a amplitude do patrimônio. Utilizando estas informações, deveriam ser realizados inventários de todos os sítios identificados, os quais deveriam ser concebidos de forma a proporcionarem uma pesquisa fácil e acesso por parte do público.

3. O inventário se constitui em componente fundamental do estudo do patrimônio industrial. ...

...Os inventários deverão incluir descrições, desenhos, fotografias e, se possível, um registro em vídeo do referido sítio industrial ainda em funcionamento, com as referências das fontes documentais." 206

206 Carta de Nizhny Tagil sobre o Património Industrial. The International Committee for the Conservation of the Industrial Heritage TICCIH. Tradução de José Manuel Lopes Cordeiro, 2003. 


\subsubsection{Metodologia do inventário}

A escolha dos bens a serem inventariados foi feita em campo, in loco, utilizando o método regressivo, na análise de vestígios de superfície, a partir de um levantamento prévio em fontes escritas e nas iconográficas.

O objeto dessa pesquisa, pode ser definido na categoria de obras de captação, entendido como o conjunto de estruturas e dispositivos construídos ou montados junto a um manancial, para a tomada de água destinada ao sistema de abastecimento. São considerados mananciais de superfície, os ribeirões, represas e reservatórios artificialmente formados. Estes últimos foram construídos como parte integrante do sistema de captação, visando assegurar a obtenção de uma vazão necessária.

Para localizá-los foi necessário percorrer as trilhas e os córregos junto aos quais se encontram as represas, procurando detectar as estruturas e os vestígios ainda existentes, assim como verificar a tecnologia empregada. Somente após a conclusão do trabalho em campo, é que as fichas de diagnóstico foram preenchidas.

A leitura e a análise deste material, apoiada na cartografia e nas fontes escritas, auxiliaram na classificação tipológica e cronológica das obras, fornecendo informações complementares, associando-se os registros fotográficos aos elementos digitalizados.

A fotografia permite ampliar, reter e fundar uma memória, individual e coletiva, de novo tipo, sem dúvida mais vasto e preciso.

A produção fotográfica pode ser objeto de estudo da Arqueologia Industrial, enquanto ramo produtivo específico com desenvolvimentos diversos em cada país, com a possibilidade da existência de uma Arqueologia Industrial da fotografia, porém, isto não é objeto desta tese.

$\mathrm{Na}$ medida em que o conjunto de procedimentos interdisciplinares da Arqueologia Industrial, incide sobre vestígios de natureza extremamente variável e, por vezes altamente complexo, a fotografia pode se constituir em instrumento fundamental para compreensão do passado.

É fonte imprescindível pela riqueza informativa do seu conteúdo, suscetível de ser ampliado para além do nível aparente imediato, devido à versatilidade própria da imagem fotográfica, funcionando como auxiliar precioso de pesquisa diacrônica e espacial de um mesmo objeto de estudo. Permite e facilita o estudo comparativo. 
"Se no campo estritamente informativo a fotografia possui os seus próprios limites, se há fenômenos inacessíveis à imagem fotográfica, há em contrapartida, "esclarecimentos" específicos, que só ela nos pode fornecer."207

No caso específico desse inventário, foi fonte indispensável de consulta, uma vez que as obras de captação foram registradas na época de sua construção pelo atelier de P. Doumet, contratado pela Repartição de Águas e Esgotos RAE, entre os anos de 1893 e 1894.

O cenário econômico promissor despertou 0 interesse de profissionais e artífices urbanos de vários setores; atraiu também estabelecimentos fotográficos. Na esteira de Militão ${ }^{208}$ vieram outros fotógrafos que se interessaram em documentar a implantação das obras de infra-estrutura que se processava na Cidade. Entre eles lembramos de P. Doumet”... ${ }^{209}$ Algumas fotografias fazem parte do álbum fotográfico das Obras da Serra da Cantareira, que segundo Kossoy, "são produtos realizados com finalidades promocionais: políticas, comerciais, institucionais, comemorativas etc. Prestam-se para construir uma identidade visual para a Cidade; prestam-se também para veicular a imagem de uma Cidade "fotogênica" ao gosto das elites". ${ }^{210}$ (KOSSOY, 2004)

"A foto, essencial para estudos de Arqueologia Industrial, é um documento social por excelência, embora haja certas distorções no caso das fotos posadas, tão comuns em tempos passados". 211

No caso das fotografias encomendadas pela RAE, pode-se notar que foram tomadas com uma finalidade científica, onde se destaca a preocupação em registrar os avanços das obras após a encampação da Companhia Cantareira, se revelando em documento ímpar para a sua contextualização. Afinal, conforme o mesmo autor:

\footnotetext{
207 SILVA, Armando Jorge. Fotografia, Arqueologia e Património Industriais, in I Encontro sobre Património Industrial, vol I, Coimbra Editora, Coimbra, 1989, p. 249

${ }^{208}$ Referência a Militão Augusto de Azevedo, um dos mais famosos fotógrafos que atuaram em São Paulo no século XIX, era natural do Rio de Janeiro.

209 KOSSOY. Boris, Luzes e sombras da metrópole: um século de fotografias em São Paulo (18501950) in História da Cidade de São Paulo na Primeira Metade do Século XX 1890 -1954.São Paulo, Paz e Terra, 2004, p. 399.

${ }^{210}$ KOSSOY. Boris, Luzes e sombras da metrópole: um século de fotografias em São Paulo (18501950) in História da Cidade de São Paulo na Primeira Metade do Século XX 1890 -1954.São Paulo, Paz e Terra, 2004, p.405.

${ }^{211}$ SOUZA de Sara Regina, Estrada de Ferro "Donna Thereza Christina" in Revista de Arqueologia Industrial vol I n 1-2 Portugal 1993 p. 78.
} 
É importante que no exame das imagens fotográficas do passado, imagens que gravaram informações de um tempo pretérito, possa o pesquisador nelas ver um caminho a mais para a compreensão, uma possibilidade ainda virgem para a descoberta. ${ }^{212}$ (KOSSOY, 1988)

Neste capítulo, traduzindo o modelo em inventário, as fotografias antigas e as atuais foram auxiliares fundamentais para a compreensão das modificações ocorridas nas edificações e no seu entorno.

A identificação de cada bem foi feita em ficha própria suficientemente detalhada com os elementos que foram considerados adequados ao seu reconhecimento, nesta premissa o modelo de ficha de inventário contém:

\section{Nome:}

Identifica o nome como o bem é conhecido cientificamente

\section{Localização:}

Onde estão situados, com o acesso.

\section{Núcleo:}

O Parque Estadual da Cantareira está subdivido em núcleos.

\section{Categoria e grupo tipológico}

Identifica o tipo de infra-estrutura da construção utilitária.

\section{Proteção existente:}

Apresenta o tipo de proteção legal, nomeadamente se é classificada como Parque Estadual; da Biosfera; Área tombada ou imóvel de interesse público.

\section{Legislação:}

Especifica o diploma legal que assegura o tipo de proteção.

\section{Visão do bem industrial no imaginário popular}

${ }^{212}$ KOSSOY, Boris. A fotografia como fonte histórica. Introdução à pesquisa e interpretação das imagens do passado. Coleção Museu e Técnicas, São Paulo, Museu da Indústria, Comércio e Tecnologia de São Paulo, 1980, p. 46. 
Como o patrimônio é conhecido pela população do entorno.

\section{Descrição Geral:}

Descreve as características e aspectos que justificam o interesse para a inventariação.

\section{Elementos notáveis:}

Elementos que se destacam em sua construção. Exemplo: a colocação de uma placa comemorativa.

\section{Época de Construção inicial:}

Data da introdução dos elementos mais antigos da construção. Caso ocorra a inexistência de elementos concretos e indicadores exatos que permitam a identificação da época com precisão será feita a partir do conjunto de características visíveis: materiais e técnicas construtivas utilizadas.

\section{Elementos datados:}

Quaisquer datas afixadas. Por exemplo: ano de fabricação ou construção.

\section{Utilização inicial:}

Aproveitamento inicial do bem ou equipamento.

\section{Utilização atual:}

Qual a reutilização.

\section{Proprietário:}

Caso não se encontre em área de domínio do Estado deve ser identificado o nome do proprietário.

\section{Construtor/Empreiteiro:}

As empresas que a edificaram.

\section{Cliente/Destinatário:}


O órgão público responsável pela contratação da empreiteira.

\section{Elementos isolados ou pontuais:}

Exemplo: uma cruz e outras peças soltas que não se inserem no espaço envolvente com valor ou significado especial.

\section{Encanamento}

Parte da barragem da represa para a caixa de registro e deste para o conduto principal.

\section{Represa:}

Elemento estrutural construído em um curso de água, transversalmente a direção de escoamento, e destinada à criação de um reservatório artificial, ou seja, represando o líquido para a regularização do consumo, em períodos de estiagem.

\section{Caixas de registro de descarga}

Encontrada em algumas represas situadas na Cantareira, abriga o registro, também conhecido como válvula, é um dispositivo que permite regular ou interromper o fluxo de água. Neste caso, era empregado principalmente quando se pretendia estabelecer uma vedação no meio do trecho que ligava ao aqueduto.

\section{Documentação de referência:}

Indica as referências bibliográficas e documentais de registros que aludem ao bem inventariado, situando o Órgão Público que possui este acervo. 
5.2.4 Ficha de inventário arqueológico industrial da herança da água

NOME

CATEGORIA/GRUPO TIPOLÓGICO

Represa [ ]

Reservatório [ ]

Encanamento [ ]

Adutora [ ]

Estrada [ ]

Outros [ ]

LOCALIZAÇÃO

S:

W:

Altitude:

Núcleo

Bairro

Meio de acesso

Dimensões Gerais

Capacidade de distribuição em 24h:

Atual:

Materiais da estrutura

Pedra [ ] tijolo [ ] concreto [ ] cimento [ ] ferro batido [ ] ferro fundido [ ]

Outros:

DENOMINAÇÃO NO IMAGINÁRIO POPULAR

DESCRIÇÃO GERAL

ELEMENTOS NOTÁVEIS

NOTA HISTÓRICA

Época da construção inicial

Séc. XIX [ ] Séc. XX [ ] Séc. XXI [ ]

Data

Fabricante

País de origem

Inventor

Arquiteto/Engenheiro

Construtor

Destinatário/Cliente

Capacidade de armazenamento:

Inicial:

Elementos datados:

UTILIZAÇÃO

Uso inicial

Uso atual

PROPRIETÁRIO

PROTEÇÃO EXISTENTE

Parque Estadual [ ] 
Área tombada [ ]

Federal [ ] Estadual [ ] Municipal [ ]

Bem tombado [ ]

Federal [ ] Estadual [ ] Municipal [ ]

Reserva da Biosfera [ ]

Outra:

Legislação

\section{DIAGNÓSTICO DO CONJUNTO}

ESTADO DE CONSERVAÇÃO

Em funcionamento................................. Sim [ ] Não [ ]

Desativado mas operacional......................Sim [ ] Não [ ]

BOM [ ] REGULAR [ ] RUIM [ ]

Retocado [ ] Transformado [ ]

Elementos incorporados:

Risco de destruição....... Iminente [ ] A médio Prazo [ ]

Tratamentos efetuados e datas:

Medida de proteção que deve ser tomada: Desassoreamento ( ) limpeza da vegetação ( ) Maior fiscalização ( ) Restauro ( )

Observações:

DETALHAMENTO

Barragem

Deterioração : Ação do tempo ( ) Atos de vandalismo ( )

Elementos que faltam :

Consequência:

Encanamento

Diâmetro.

Espessura:

Material:

Deterioração : Ação do tempo ( ) Atos de vandalismo ( )

Elementos que faltam:

Consequência

Caixa de Registro de descarga

Deterioração : Ação do tempo ( ) Atos de vandalismo ( )

Elementos que faltam :

Consequência:

DOCUMENTAÇÃO DE REFERÊNCIA/LOCALIZAÇÃO DO ACERVO BIBLIOGRAFIA ICONOGRAFIA OBSERVAÇÕES 
5.3 Herança da água ${ }^{213}$

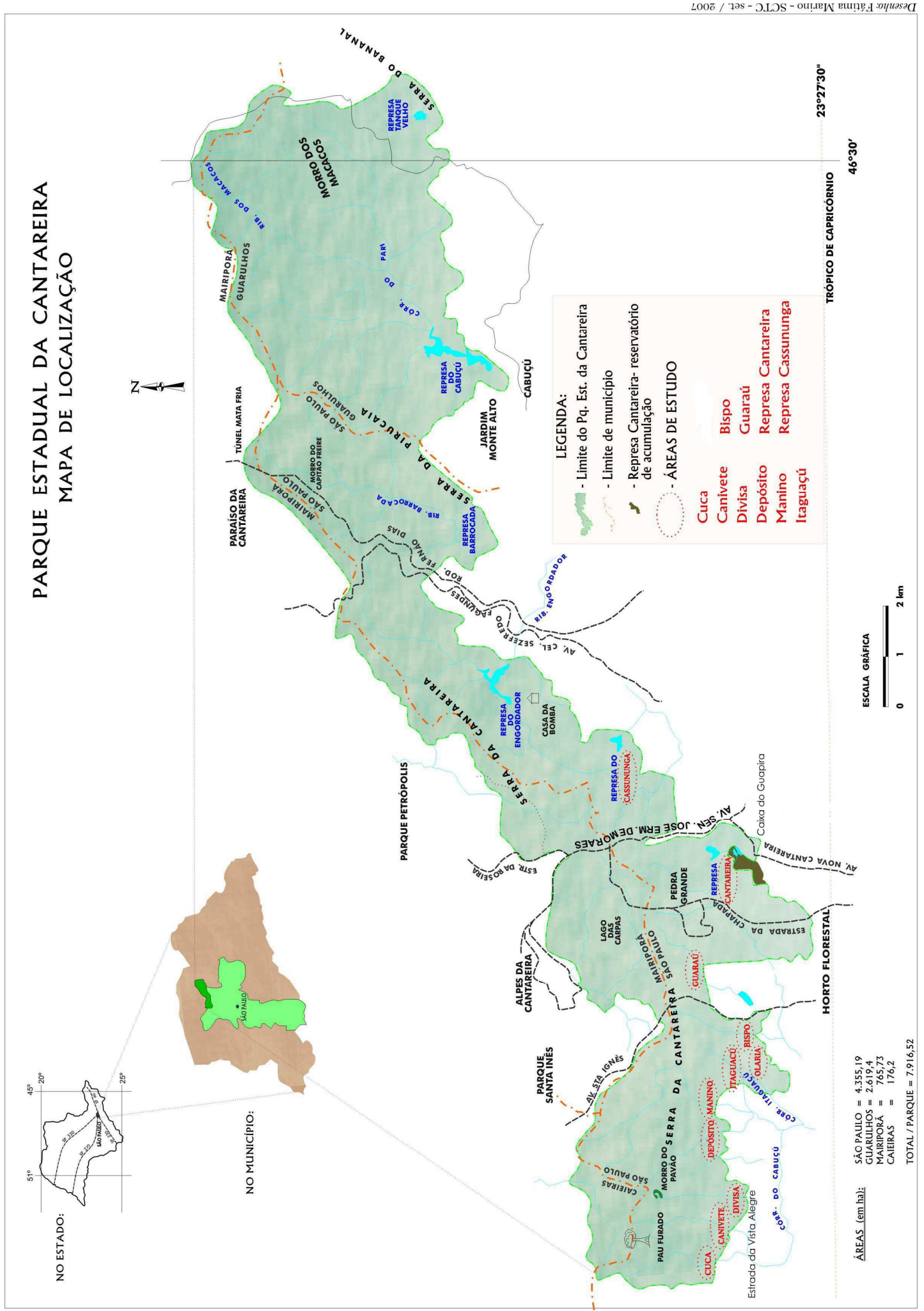

Mapa da Cantareira com Áreas de pesquisa

${ }^{213}$ Water Heritage - Expressão consagrada pela Water Authorities Association, Inglaterra. 


\subsubsection{Represa Cantareira: antigos reservatórios de acumulação}

Localização: $23^{\circ} 26^{\prime} 30.87^{\prime \prime S} 46^{\circ} 37^{\prime} 21^{\prime \prime} \mathrm{W}$

Está fora dos limites do Parque Estadual da Cantareira, na Rua Luís Carlos Gentile de Laet, no 2500, bairro da Vila Rosa, entre a Estrada da Chapada e a Avenida Cantareira.

Altitude: $815,50 \mathrm{~m}$

Meio de acesso: Facilitado, é o ponto final da linha de ônibus Vila Rosa.

Capacidade de distribuição em 24: 3.000 .000 de litros

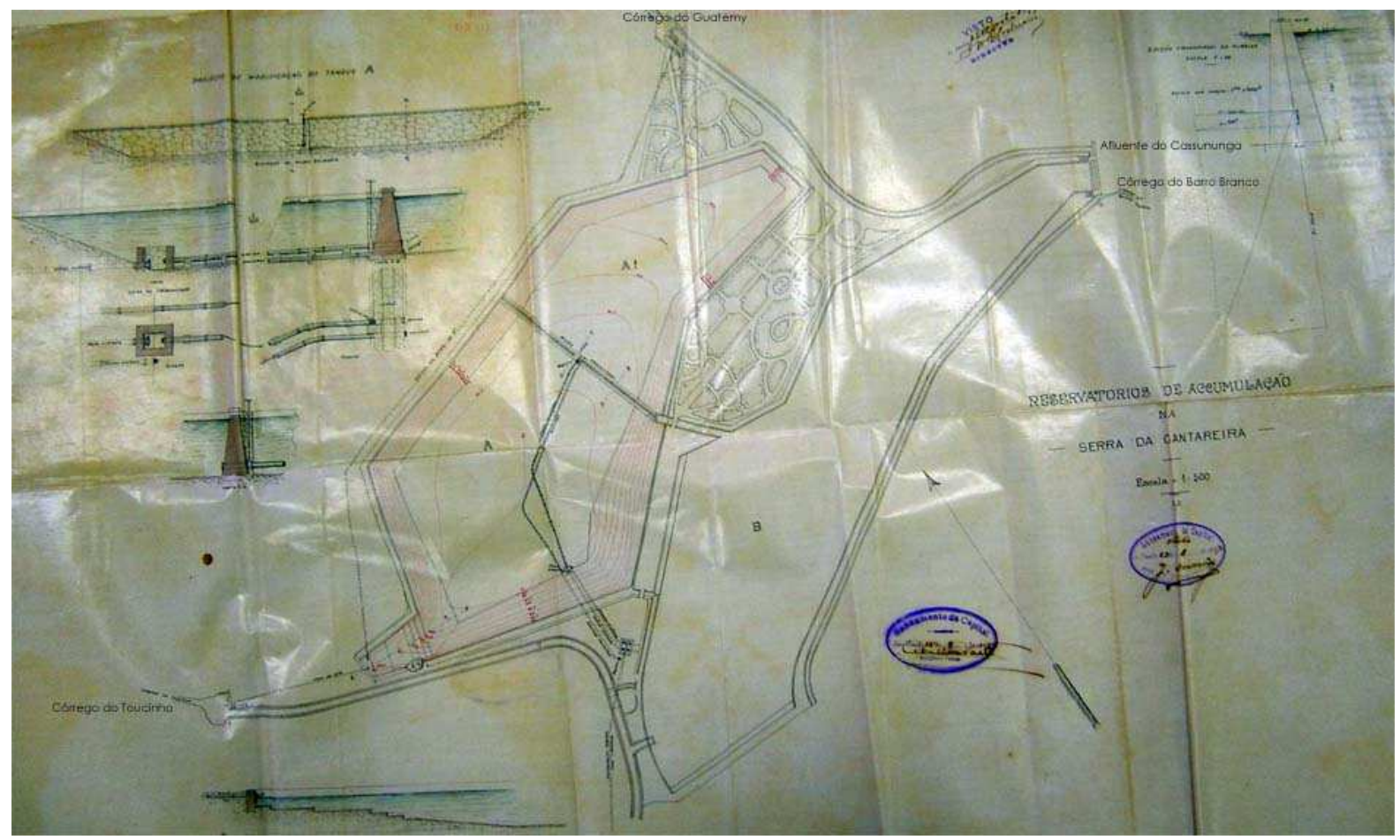

Planta dos Reservatórios de Accumulação Escala 1:500 RAE Acervo do Arquivo do Estado de São Paulo 


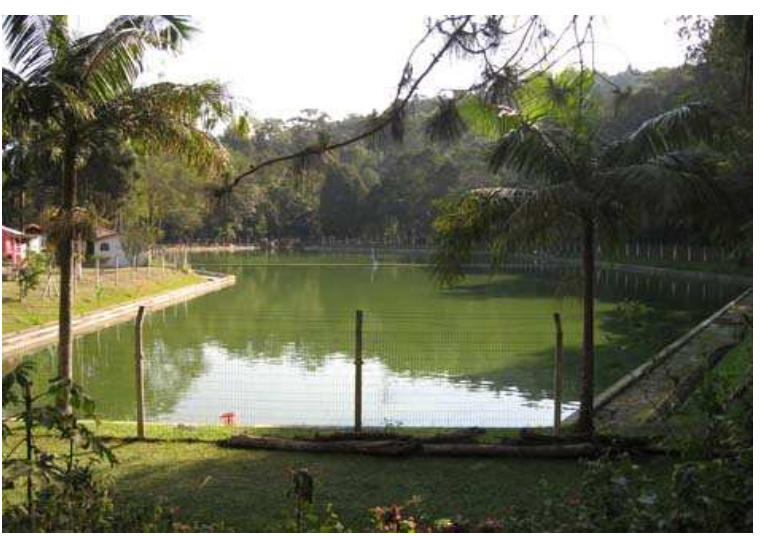

Reservatório A

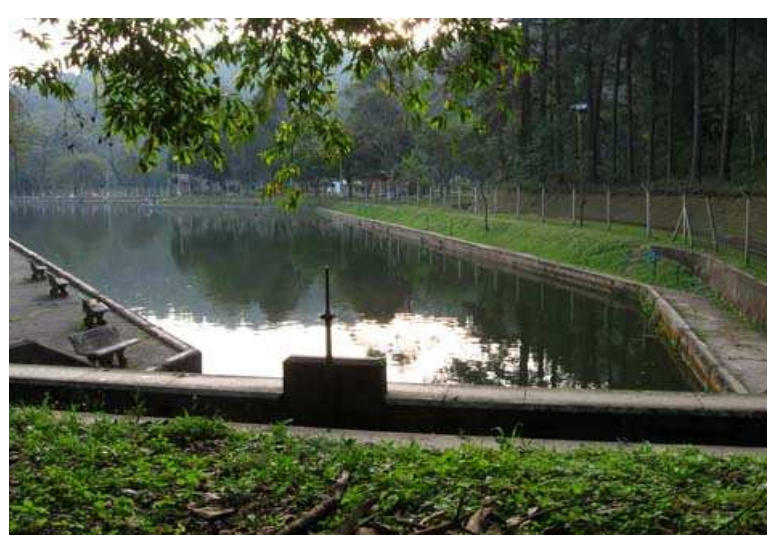

Reservatório B

Material da estrutura: Pedra, tijolo e concreto

Construtor: Companhia Cantareira e Repartição de Águas e Esgotos.

Elementos datados: Consta a data de 1882, na antiga casa de registro, atual capela de Nossa Senhora Aparecida.

Não foram autorizadas pesquisas no seu interior

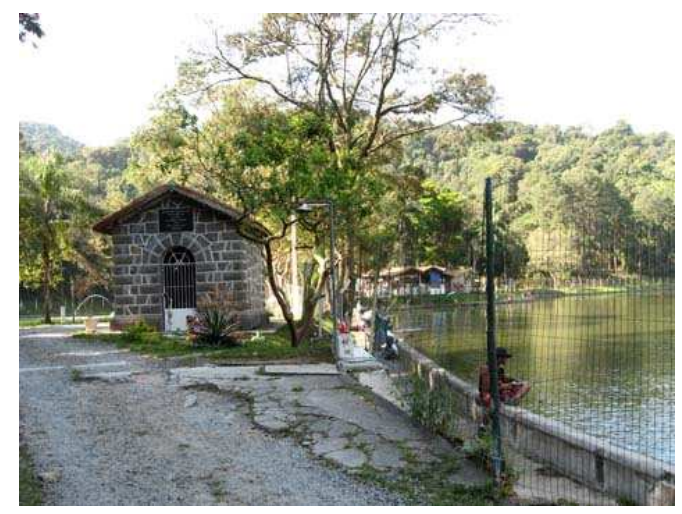

Casa de registro

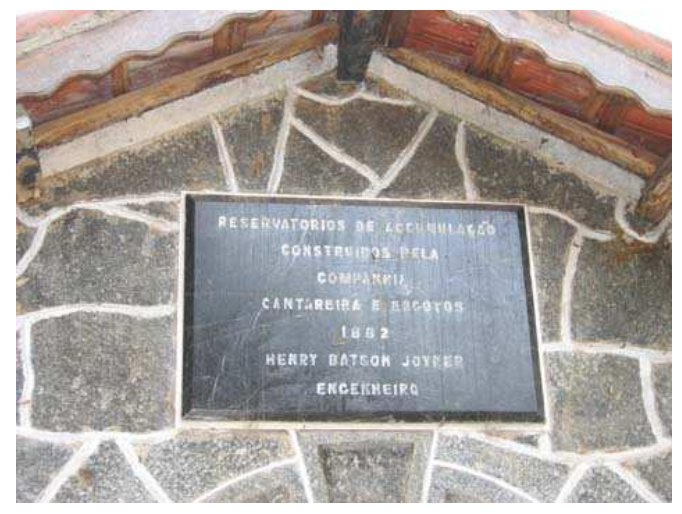

Placa afixada na entrada

\section{Nota Histórica:}

Os Reservatórios de Acumulação são estruturas ligadas ao armazenamento de água, para Martins, este tipo de obra, é um lago artificial criado em um curso de água com a construção de uma barragem, com a finalidade de represar a água para resolver um ou diversos problemas de engenharia hidráulica ou sanitária. ${ }^{214}$ (MARTINS, 1987)

\footnotetext{
${ }^{214}$ MARTINS, J. A. Reservatórios de Acumulação e Barragens" in Técnica de Abastecimento e tratamento de água, CETESB, São Paulo,1987 p.255.
} 
Construído pela Companhia Cantareira entre 1877 e 1881, recebia as águas dos ribeirões Toucinho, Guatemy e Barro Branco, porém, não cumpria alguns princípios básicos para esse tipo de obra onde as vazões disponíveis nos cursos de água tem que ter médias superiores às necessidades de consumo, e por outro lado, o líquido disponível deve ser acumulado durante os períodos chuvosos, para que se tenha uma reserva suficiente, durante os períodos de estiagens, com o intuito de cobrir o deficit entre a demanda e as vazões mínimas.

Essa deficiência não foi notada no início do abastecimento, mas à medida que aumentava a população e ocorria um desenvolvimento da cidade aliada a uma maior demanda industrial e comercial, faltava água nas torneiras paulistanas, nos períodos não chuvosos.

Atenção particular tinha que ser dada as condições que facilitassem a construção das obras de captação e adução, com acesso fácil, principalmente, aos materiais de construção e a mão de obra, e isto também parece que não foi levado em conta pela empresa.

$\mathrm{Na}$ época da encampação, os engenheiros da Superintendência de Obras Públicas, constataram o estado lastimável de conservação do local, sendo obrigados a realizar reparos em caráter de urgência. Tiveram que reconstruir as represas do Toucinho e Guatemy, colocando registros de descarga para realizar a limpeza, que segundo os relatórios da época, nunca tinha sido feita.

Represa do Guatemy:

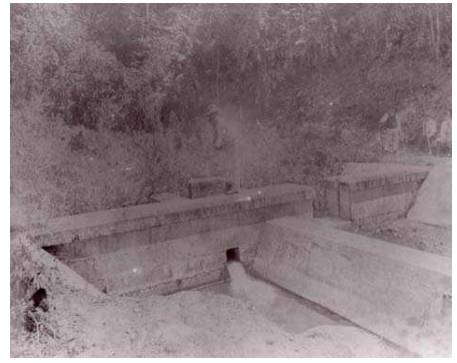

1893 P. Doumet

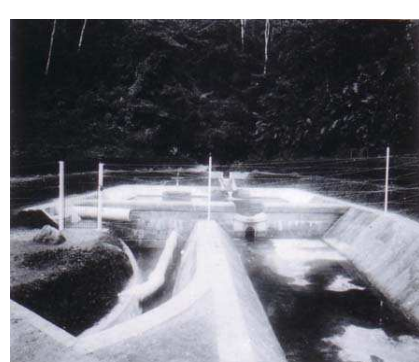

1894 P. Doumet

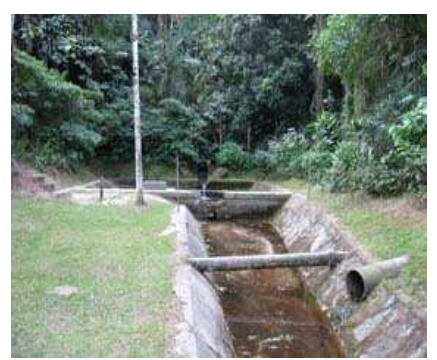

2007

Em setembro de 2007, se pode observar que sofreu modificações, o lado esquerdo foi aterrado e a cerca de proteção retirada.

As fotos de 1893 foram tiradas, assim que a Superintendência de obras chegou ao local. Em 1894, quando foi reconstruída pela RAE. 
Represa do Toucinho:

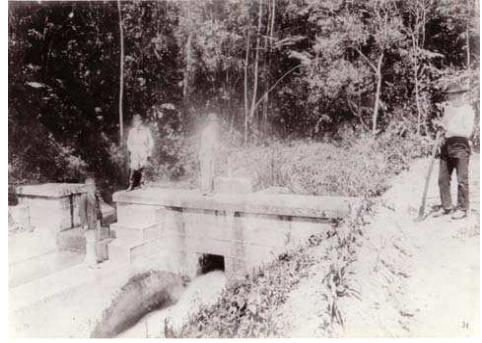

1893 P. Doumet

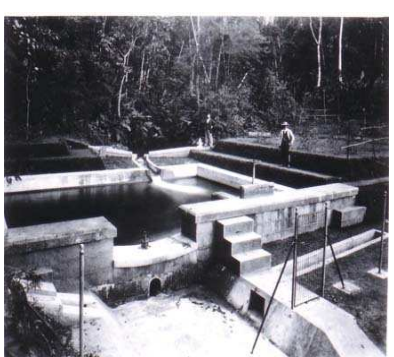

1894 P. Doumet

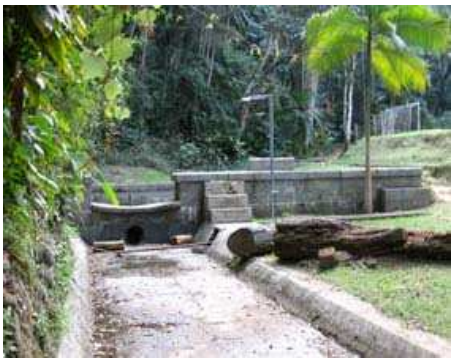

2007

Em 1893, o reservatório B, passou a receber as águas de um dos afluentes do Cassununga, suas sobras foram enviadas para a caixa de junção do Guapira, que alimentava o reservatório da Consolação.
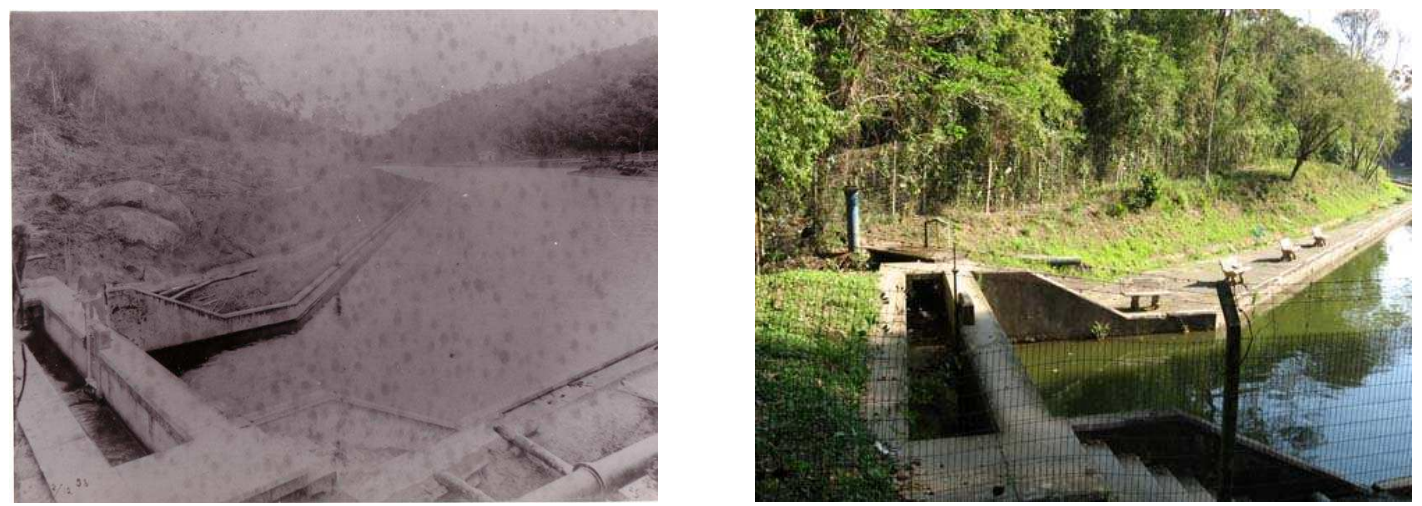

Reservatório de Acumulação - Entrada B do afluente, setembro de 2007 do Cassununga - 1893 - Acervo Museu da SABESP

\section{UTILIZAÇÃO DO CONJUNTO}

\section{Uso inicial}

Armazenamento de água para o Reservatório da Consolação.

\section{Uso atual}

Área de pesca, a entrada é permitida pagando uma taxa na portaria. O entorno do reservatório é de acesso restrito, podendo freqüentá-lo, somente, os sócios do Clube de Campo da Associação SABESP.

Proprietário: SABESP 


\section{Diagnóstico do Conjunto}

Está em bom estado de conservação, porém, foi descaracterizado de sua função original. No local funciona um "pesque e pague".

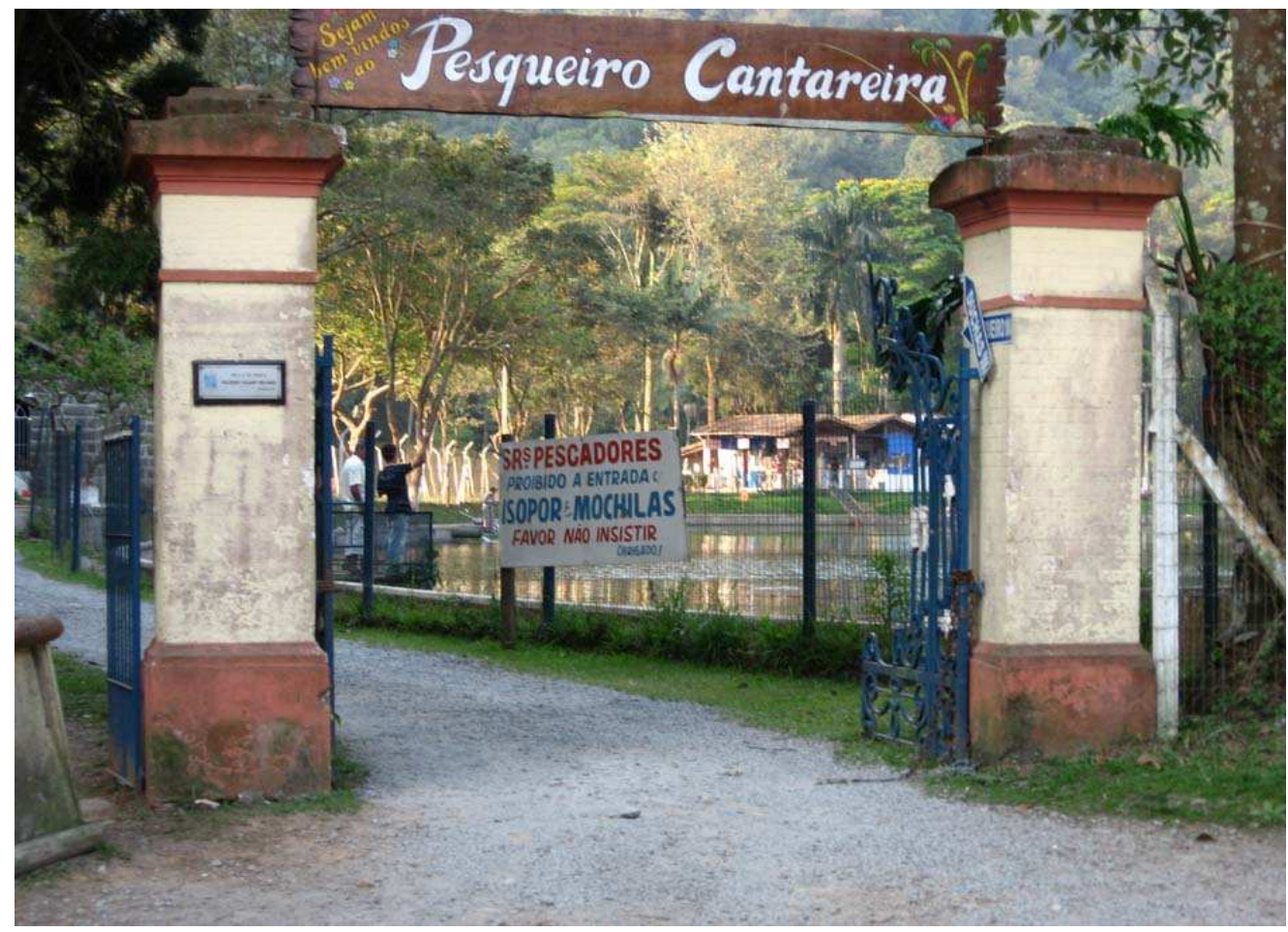

Entrada do Clube da SABESP. Reservatórios de Acumulação A e B

Detalhamento e observações:

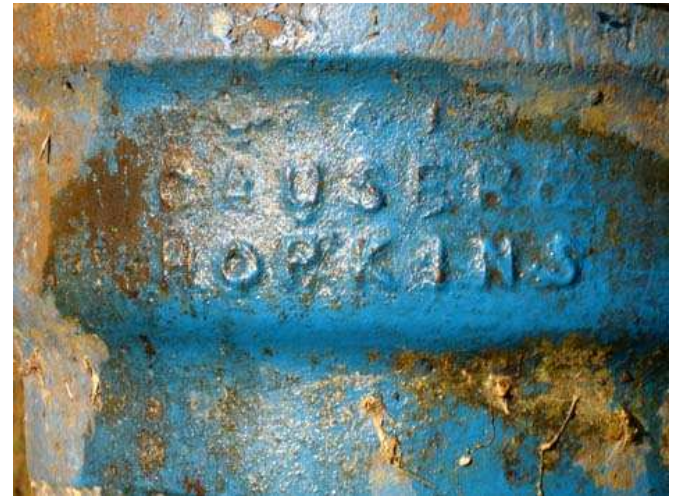

Encanamento entre a represa do Guatemy e o Reservatório A - Setembro de 2007

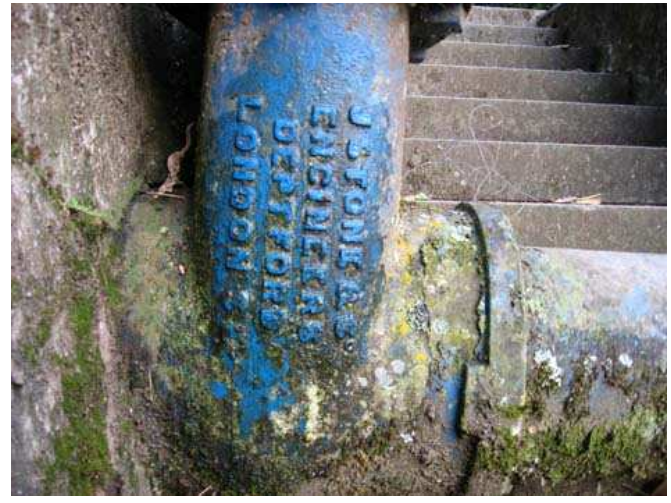

Ligação da Represa do Toucinho e o Reservatório B - Setembro de 2007 
Os encanamentos encontrados vieram da Inglaterra, através da importadora, Causer Hopkins, que possuía uma filial na cidade de São Paulo.

Bibliografia: Relatórios da Repartição de Águas e Esgotos e da Secretaria de Agricultura.

Documentação do Arquivo do Estado de São Paulo.

\section{Iconografia}

Álbum fotográfico P. Doumet - 1893 - Acervo Arquivo do Estado de São Paulo Fotos P. Doumet - 1894 Acervo particular.

\subsubsection{Parque estadual da Cantareira}

- Represas situadas à esquerda da Avenida Santa Inês, sentido Mairiporã.

As construções hidráulicas encontradas ao longo da divisa do Parque Estadual da Cantareira, são de pequenas dimensões, e foram construídas para a captação, o armazenamento e a distribuição das águas dos ribeirões e dos mananciais da Serra.

Datadas do final do século XIX, estas estruturas foram arquitetadas com a finalidade de suprir as necessidades de consumo de água da população paulistana. O Poder Público tomou o cuidado de desapropriar toda a área procurando impedir possíveis contaminações antrópicas.

Nos primeiros meses de 1893, surgiram dificuldades no recebimento dos tubos de aço Mannesmann, a empresa com sede em Berlim comunicou o atraso na remessa do material alegando a ruptura dos laminadores, o que inviabilizava a sua entrega imediata.

A Superintendência de Obras logo percebeu que deveria usar os tubos de $600 \mathrm{~mm}$ que existiam no estoque do depósito, mas que não tinham ainda sido utilizados devido ao seu peso.

Como a maior dificuldade para o assentamento desses canos consistia no respectivo transporte, procurou-se aumentar o número de carretões, que tinham sido preparados para as obras de canalização do Cassununga.

A Companhia Viação Paulista, auxiliou levando o encanamento da Estação da Luz até Santana, e daí vinte e sete carroças carregadas diariamente transportaram o material para o local das obras, o que foi considerado uma façanha para a época, 
uma vez que para a opinião pública era impossível fazer esse tipo de transporte sem a via férrea, que ainda não tinha sido inaugurada. $O$ tramway transportou o restante de todo o aparato para a continuidade das obras.

\subsubsection{Represa da Cuca}

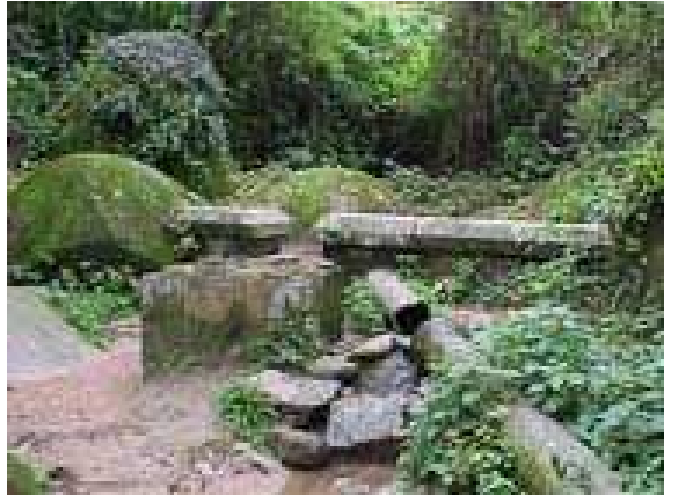

Foto 2000

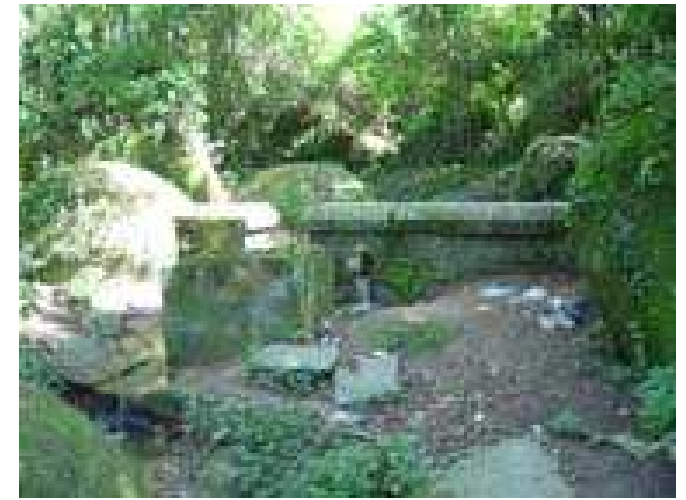

Foto 2007

Localização: S $23^{\circ} 26^{\prime} 10.6^{\prime \prime}$ W 46² $42^{\prime} 01.04^{\prime \prime}$

Altitude: $839 \mathrm{~m}$

Bairro: Taipas

Meio de acesso: Estrada da Vista Alegre

Dimensões Gerais: $8,70 \mathrm{~m}$ de frente com 2,70 de lateral

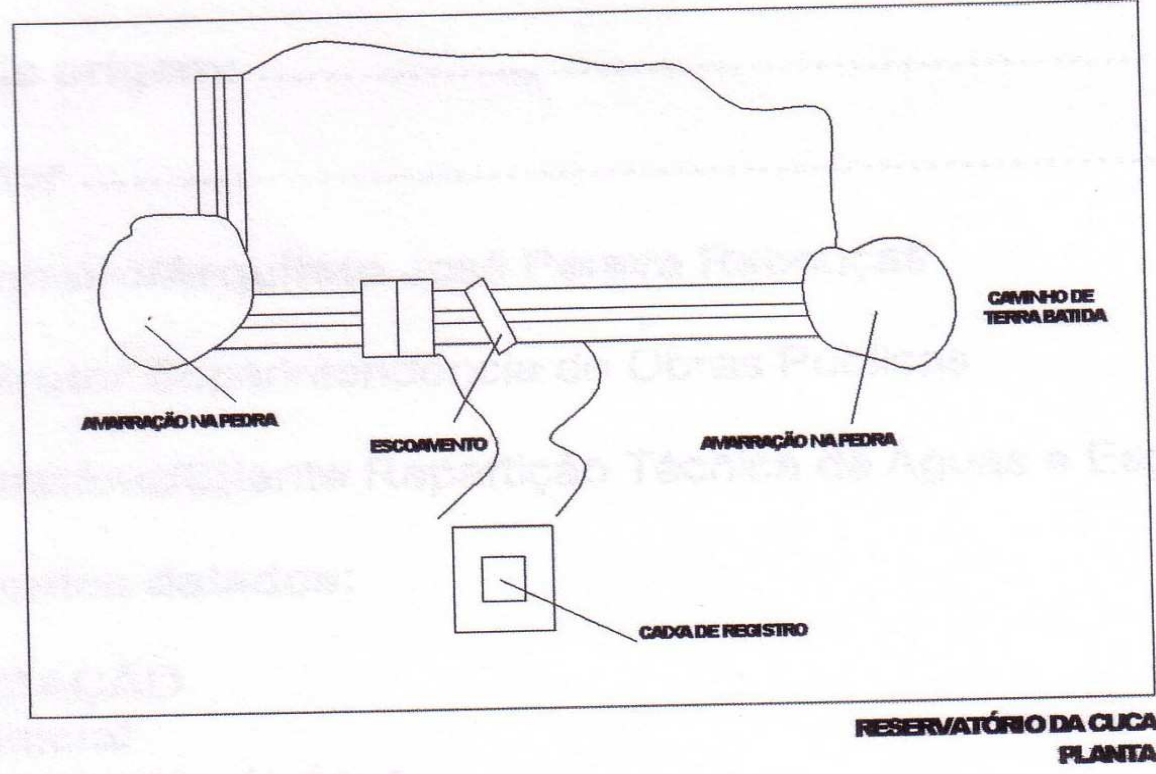

Reservatório da CUCA 
Materiais da estrutura: pedra.

Descrição Geral: Constituída por uma barragem de alvenaria com $650 \mathrm{~mm}$ de espessura, com um vertedouro de $1,00 \mathrm{~m}$ de vão com $600 \mathrm{~mm}$ de altura.

$O$ duto de ferro fundido tem $300 \mathrm{~mm}$ de diâmetro com $18 \mathrm{~mm}$ de espessura.

Em frente ao muro está a caixa de registro de descarga de 1,30 m por 1,40.

Nota histórica:

Data: 1894

UTILIZAÇÃO

Uso inicial: Represamento

Uso atual: Desativada

PROPRIETÁRIO: Próprio Estadual

\section{DIAGNÓSTICO DO CONJUNTO}

\section{ESTADO DE CONSERVAÇÃO}

Desativado mas operacional

Risco de destruição: A médio prazo .

Medida de proteção que deve ser tomada: Desassoreamento; limpeza da vegetação; Maior fiscalização; Restauro.

\section{DETALHAMENTO}

Barragem

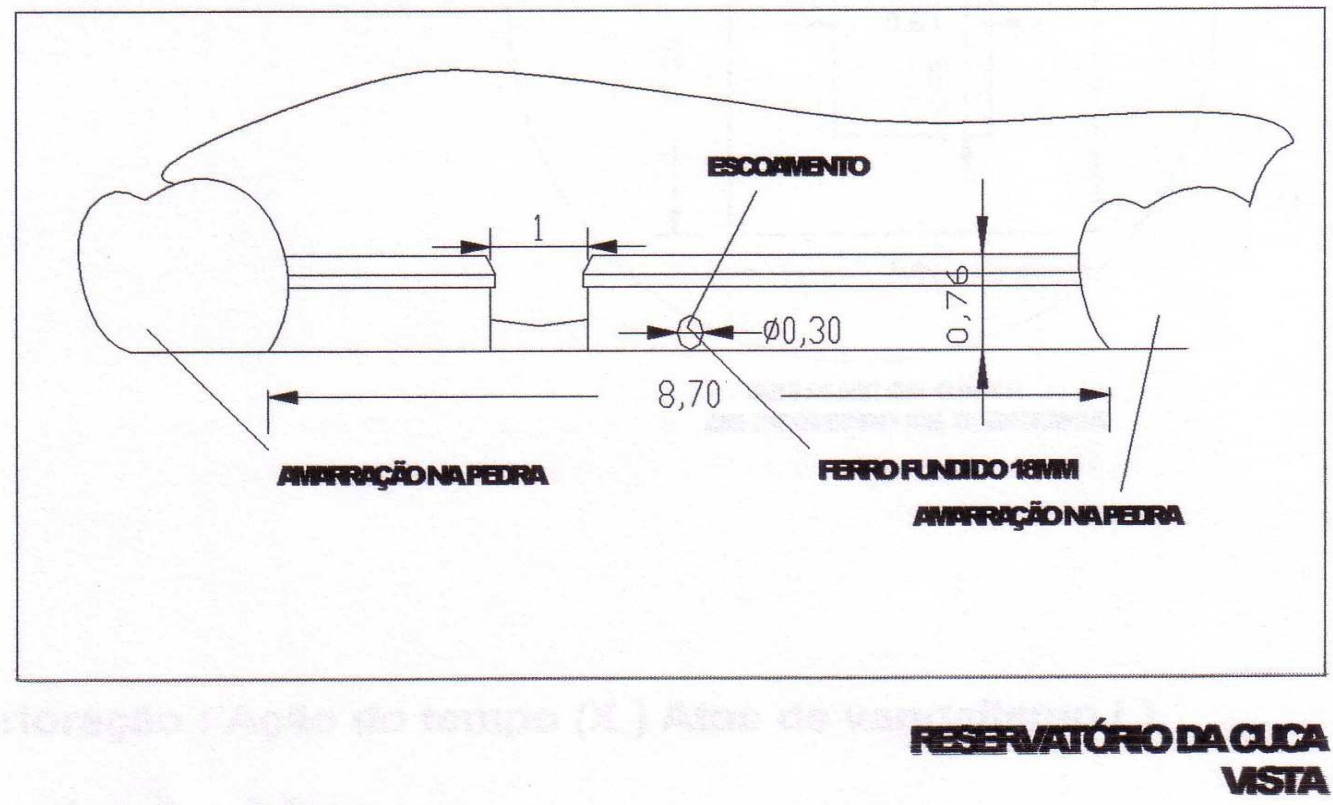

Vista: Reservatório da CUCA

Deterioração : Ação do tempo (x) Atos de vandalismo (x)

Elementos que faltam : Encanamento 
Conseqüência: não tem mais ligação com a caixa de registro

\section{Encanamento}

Diâmetro: $300 \mathrm{~mm}$

Espessura: $18 \mathrm{~mm}$

Material: Ferro fundido

Deterioração: Ação do tempo ( ) Atos de vandalismo (x )

\section{Bibliografia:}

- Relatórios da Repartição de Águas e Esgotos e da Secretaria de Agricultura.

- Documentação do Arquivo do Estado de São Paulo

\section{Iconografia}

- Fotos Acervo particular

\subsubsection{Represa do Canivete}

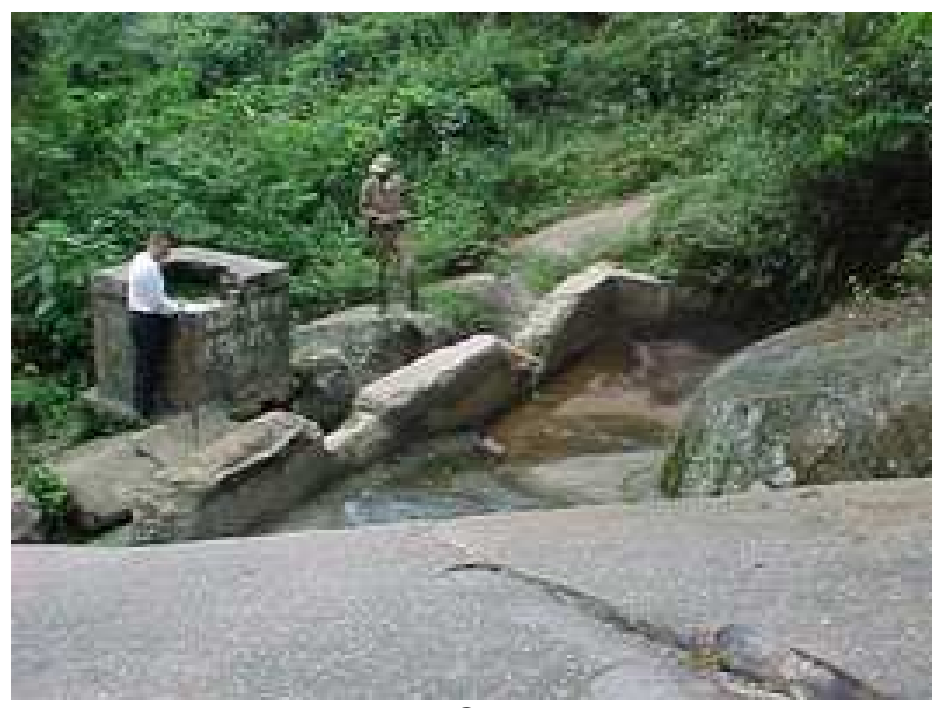

Represa do Canivete 2006

LOCALIZAÇÃO: S23o26'22.8" W46o 41'35.8"

Altitude: $847 \mathrm{~m}$

Meio de acesso: Estrada da Vista Alegre

Dimensões Gerais 


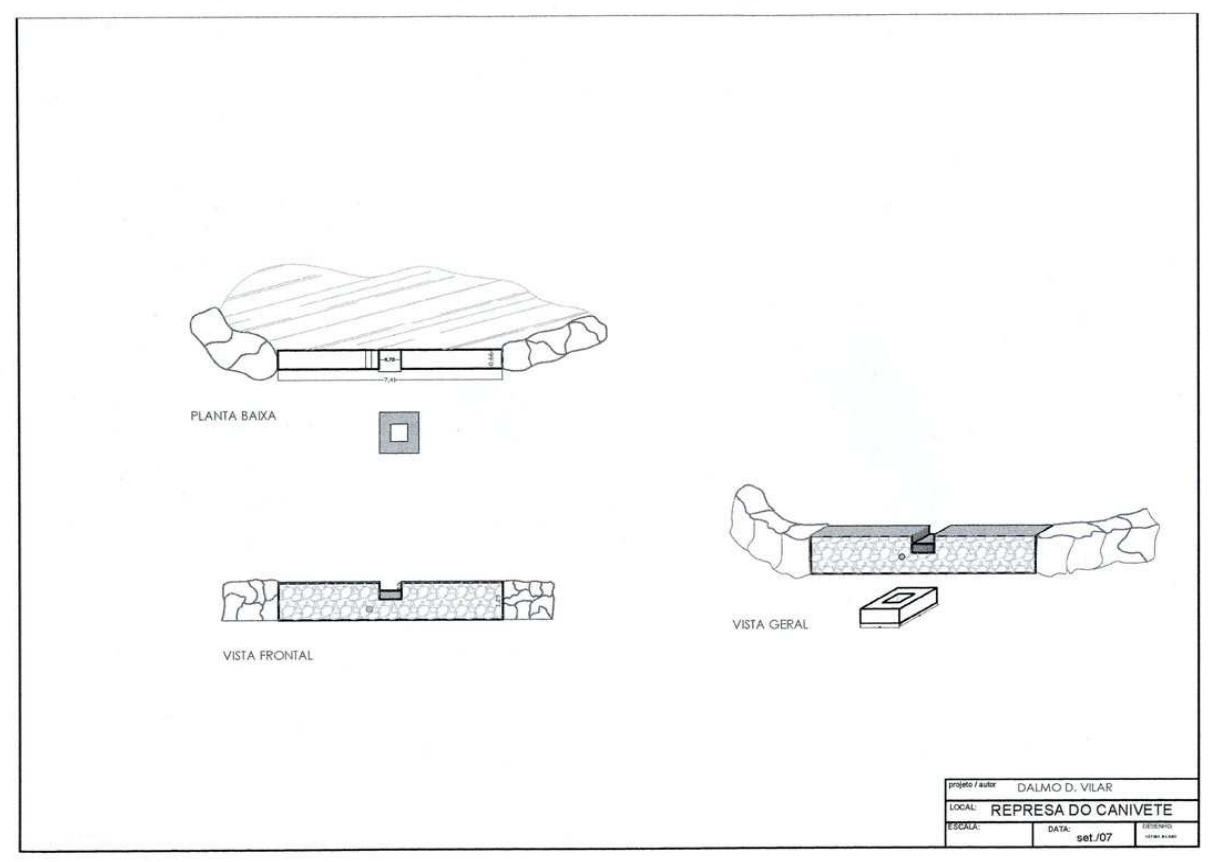

Represa do Canivete

Materiais da estrutura: Pedra $[\mathrm{x}]$ tijolo $[\mathrm{x}]$ concreto [ ] cimento [x ]

Descrição Geral: Pequena estrutura constituída por uma barragem de alvenaria. Data: 1894.

Proprietário: Próprio Estadual

\section{DIAGNÓSTICO DO CONJUNTO}

Estado de conservação: Ruim [x ]

Em funcionamento: Sim [ ] Não [ $x$ ]

Risco de destruição: Iminente [ $x$ ]

Medida de proteção que deve ser tomada: Impedir o acesso e efetuar restauro.

Observações: Os tijolos estão aparentes devido a atos de vandalismo.

\section{DETALHAMENTO}

\section{Barragem}

Deterioração : Ação do tempo (x ) Atos de vandalismo (x)

Elementos que faltam: tijolos e parte do revestimento

\section{Encanamento}

Diâmetro. 200mm

Espessura: $15 \mathrm{~mm}$

Material: Ferro fundido

Deterioração: Ação do tempo ( ) Atos de vandalismo (X) 


\subsubsection{Represa da Divisa}

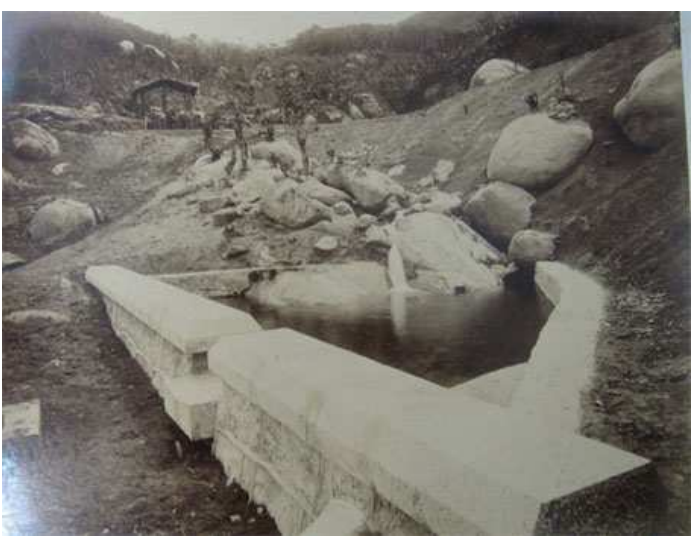

Foto P. Doumet 1894

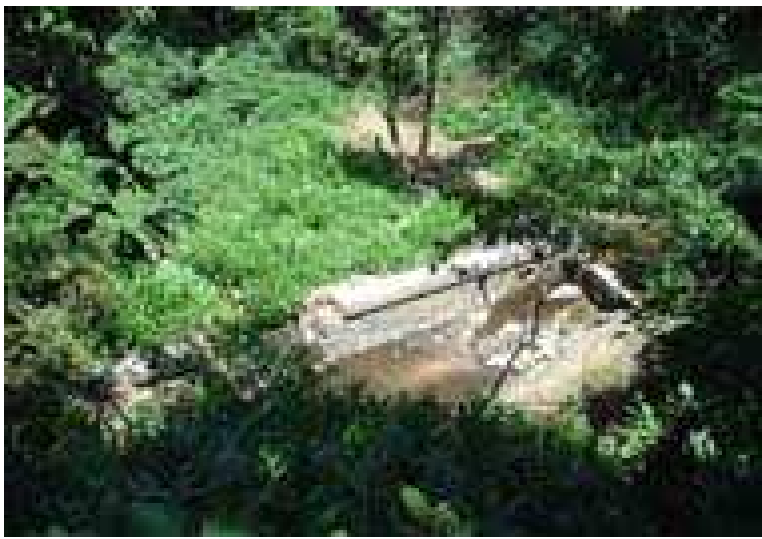

Foto 2006

Localização: S $23^{\circ} 26^{\prime} 33.1^{\prime \prime} \mathrm{W} 46^{\circ} 41^{\prime} 13.6^{\prime \prime}$

Altitude: $834 \mathrm{~m}$

Meio de acesso: Estrada da Vista Alegre

Materiais da estrutura: Pedra $[\mathrm{x}]$ tijolo $[\mathrm{x}]$ concreto $[\mathrm{x}]$ cimento $[\mathrm{x}]$

Data: 1894.

Proprietário: Próprio Estadual

\section{DIAGNÓSTICO DO CONJUNTO}

Estado de Conservação:

Em funcionamento: Sim [ ] Não [x ]

Ruim [ X ] Incompleto (x)

Risco de destruição: Iminente $[x]$

Natureza da deterioração: Assoreamento, destruição de aproximadamente 2,70m da barragem. Foi constatada a presença de lixo doméstico, e de criação de suíno, provocando um odor desagradável.

Presença de estranhos, com ameaça a integridade física dos pesquisadores.

Medida de proteção que deve ser tomada: Impedir o acesso, vigilância constante, efetuar restauro e limpeza da vegetação e do lixo doméstico.

Observações: Os tijolos estão aparentes.

\section{DETALHAMENTO}

Barragem : $15 \mathrm{~m}$ de comprimento, com 1,60m de altura

Deterioração : Ação do tempo (x) Atos de vandalismo (x)

Elementos que faltam: tijolos e parte do revestimento

\section{Encanamento}

Diâmetro: $420 \mathrm{~mm}$

Espessura: $35 \mathrm{~mm}$

Material: Concreto

Deterioração : Ação do tempo ( ) Atos de vandalismo (X) 


\section{Bibliografia}

- Relatórios da Repartição de Águas e Esgotos e da Secretaria de Agricultura.

- Documentação do Arquivo do Estado de São Paulo

\section{Iconografia}

- Álbum fotográfico P. Doumet de 1894 - Acervo Escola Politécnica - USP

\subsubsection{Represa do Depósito}

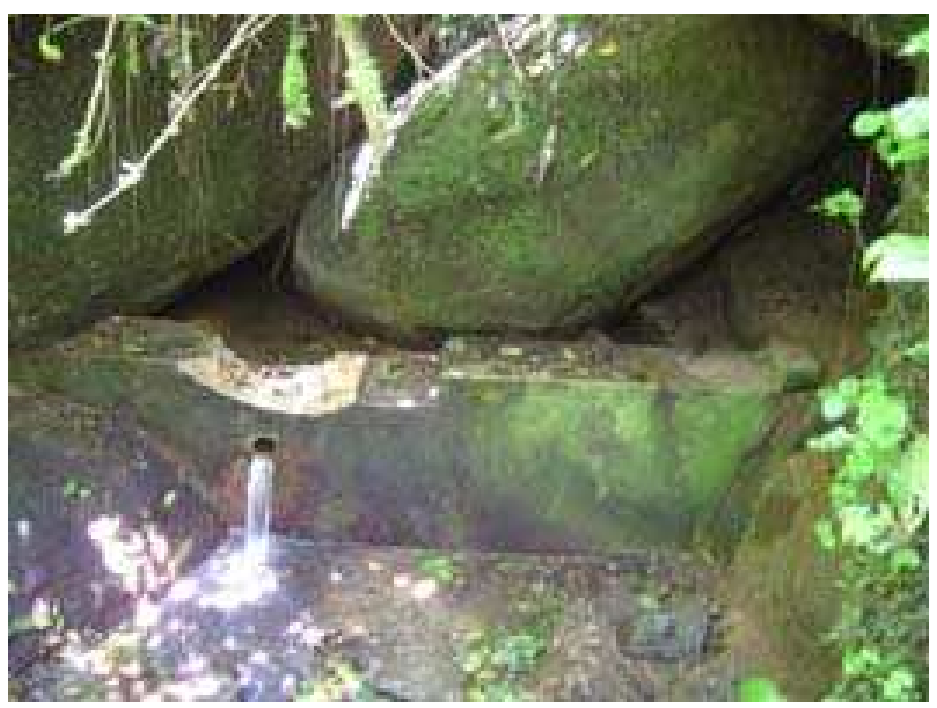

Foto Represa do Depósito 2006

Localização: S $23^{\circ} 26^{\prime} 22.2^{\prime \prime}$ W $46^{\circ} 40^{\prime} 47.0^{\prime \prime}$

Altitude: $837 \mathrm{~m}$

Meio de acesso: Estrada da Vista Alegre

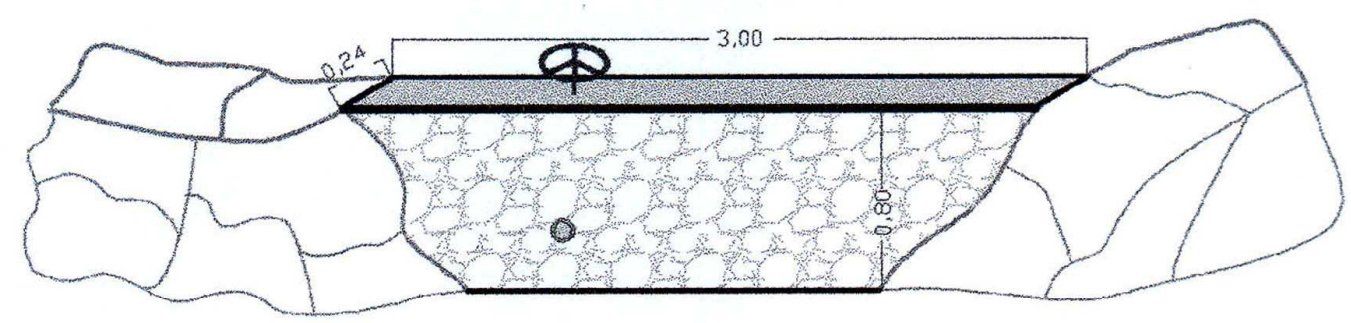

VISTA GERAL

Dimensões Gerais 
Materiais da estrutura: tijolo $[x]$ cimento $[x]$

\section{Descrição Geral}

Pequena estrutura constituída por uma barragem de alvenaria.

Parte superior destruída provavelmente na tentativa de retirar o registro de descarga do encanamento.

É a única represa em que o acesso é feito por uma escada de 4 degraus.

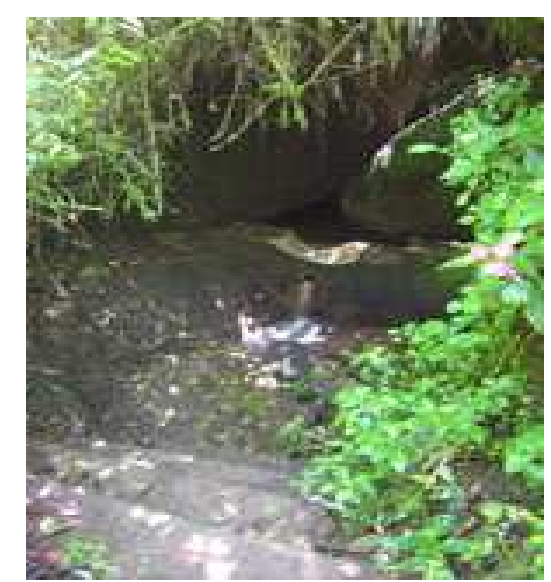

Foto 2006

Data: 1894.

Proprietário: Próprio Estadual

\section{DIAGNÓSTICO DO CONJUNTO}

ESTADO DE CONSERVAÇÃO

Em funcionamento Sim [ ] Não [X ]

Ruim [ $\mathrm{x}$ ] Incompleto (x)

Risco de destruição: Iminente [x]

Natureza da deterioração: Atos de vandalismo

Elementos que faltam: Registro de descarga

Medida de proteção que deve ser tomada: Impedir o acesso, efetuar restauro e maior fiscalização

Observações: Os tijolos estão aparentes.

\section{DETALHAMENTO}

\section{Barragem}

Deterioração: Ação do tempo (x) Atos de vandalismo (x)

Elementos que faltam: tijolos e parte do revestimento

\section{Encanamento:}

Diâmetro: $85 \mathrm{~mm}$

Espessura: $3 \mathrm{~mm}$

Material: Ferro fundido

Deterioração: Ação do tempo ( ) Atos de vandalismo (X) 


\subsubsection{Represa do Manino}

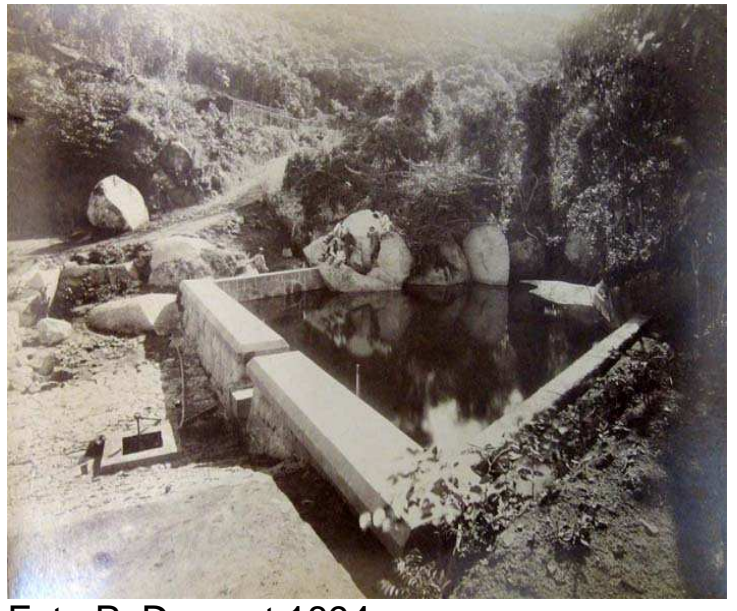

Foto P. Doumet 1894

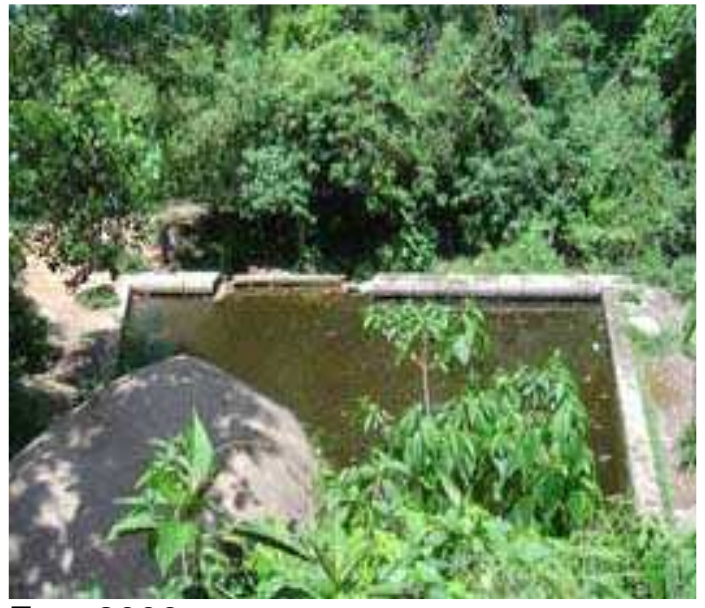

Foto 2006

Localização: S 2326'22.8” W 46 $46^{\circ}$ '32.6”

Altitude: $831 \mathrm{~m}$

Meio de acesso: Estrada da Vista Alegre

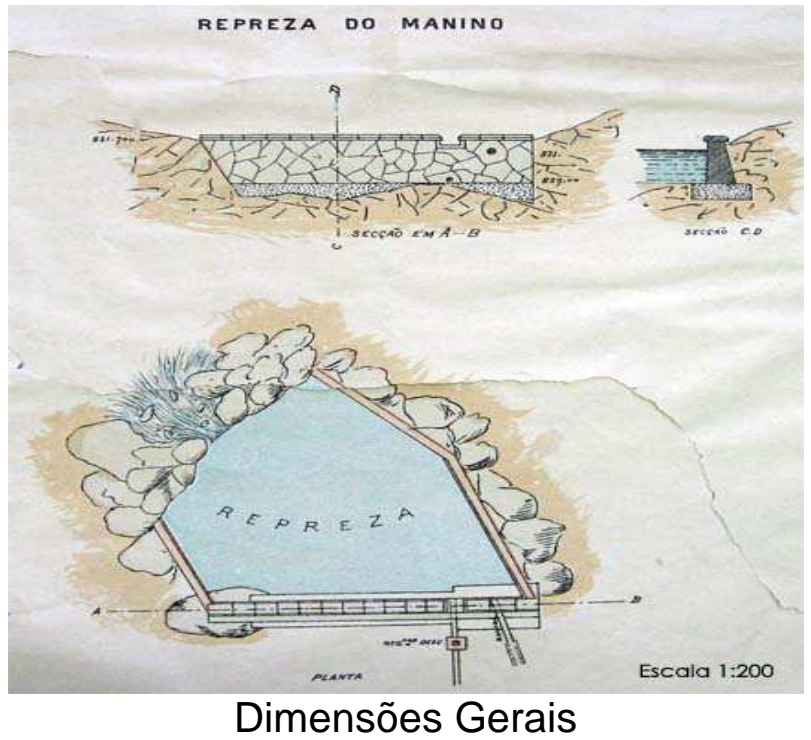

Capacidade de distribuição em 24 h:1.600.000 litros

Materiais da estrutura: tijolo $[\mathrm{X}]$ cimento $[\mathrm{X}] \operatorname{concreto}(\mathrm{X})$ pedra $(\mathrm{X})$

Data: 1894.

PROPRIETÁRIO: Próprio Estadual 


\section{DIAGNÓSTICO DO CONJUNTO}

\section{ESTADO DE CONSERVAÇÃO}

Em funcionamento: $\operatorname{Sim}[$ [ Não [x ]

Ruim [ $\mathrm{X}$ ] Incompleto $(\mathrm{x})$

Risco de destruição: Iminente [x]

Natureza da deterioração: Atos de vandalismo

Elementos que faltam: parte da barragem

Medida de proteção que deve ser tomada: Impedir o acesso, efetuar restauro e maior fiscalização

Observações: Parte da barragem está destruída não permitindo inferir as medidas do vertedouro

\section{DETALHAMENTO}

Barragem: $16,70 \mathrm{~m}$ de comprimento, por $1 \mathrm{~m}$ de largura e 1,25 de altura.

Deterioração : Ação do tempo (x) Atos de vandalismo (x)

Elementos que faltam: tijolos, blocos de granito e parte do revestimento

\section{Encanamento:}

Diâmetro: $800 \mathrm{~mm}$

Espessura: $25 \mathrm{~mm}$

Material: Ferro batido

Deterioração : Ação do tempo ( ) Atos de vandalismo ( )

Iconografia: Detalhes da Planta da Repartição Técnica de Águas e Esgotos $-1^{\text {a }}$

Divisão - Serviços de captação realizados na Serra da Cantareira durante o ano de 1894 - Escala 1:200 Acervo Arquivo do Estado de São Paulo OBS. Grafia conforme o original

Álbum fotográfico P. Doumet de 1894 - Acervo Escola Politécnica - USP

\subsubsection{Represa do Ytaguassu}

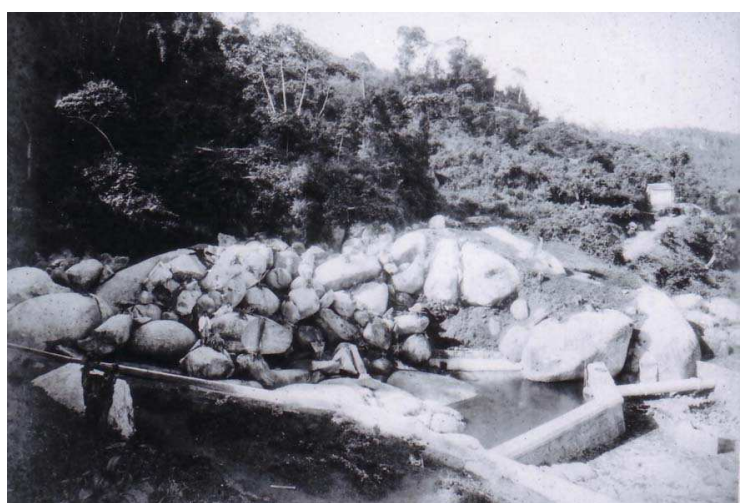

Foto P. Doumet 1894

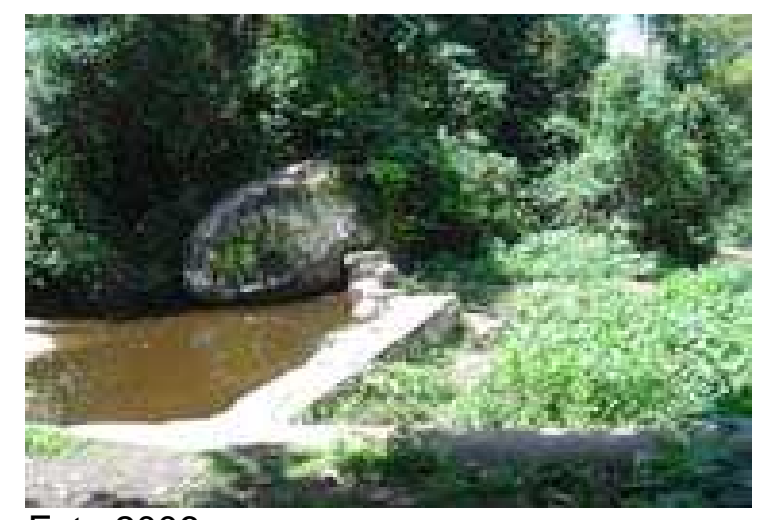

Foto 2006

Localização: S $23^{\circ} 26^{\prime} 18.6^{\prime \prime}$ W $46^{\circ} 40^{\prime} 11.8^{\prime \prime}$

Altitude: $830 \mathrm{~m}$

Meio de acesso: Estrada da Vista Alegre 


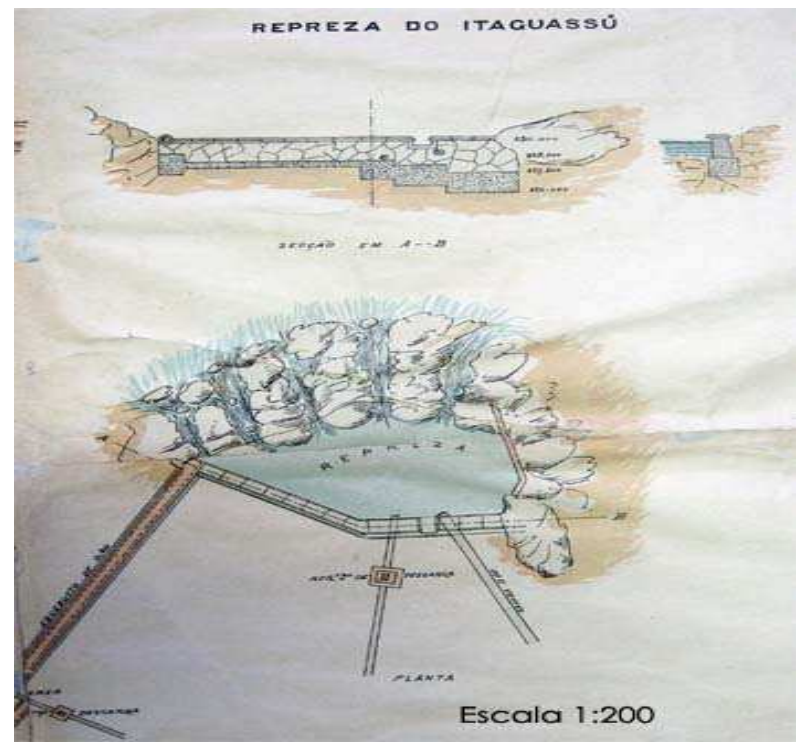

Dimensões Gerais

Capacidade de distribuição em 24 h: 5.000 .000 litros

Materiais da estrutura: tijolo $[\mathrm{X}]$ cimento $[\mathrm{X}] \operatorname{concreto}(\mathrm{X})$ pedra $(\mathrm{X})$

Data: 1893.

Propietário: Próprio Estadual

\section{DIAGNÓSTICO DO CONJUNTO}

Estado de Conservação:

Em funcionamento: Sim [ ] Não [x ]

Ruim [ $\mathrm{x}$ ] Incompleto (x)

Risco de destruição: Iminente $[x]$

Natureza da deterioração: Atos de vandalismo

Elementos que faltam: parte da barragem

Medida de proteção que deve ser tomada: Impedir o acesso, efetuar restauro e maior fiscalização.

Observações:

Detalhamento:

REPREZA DO ITAGUASSÚ

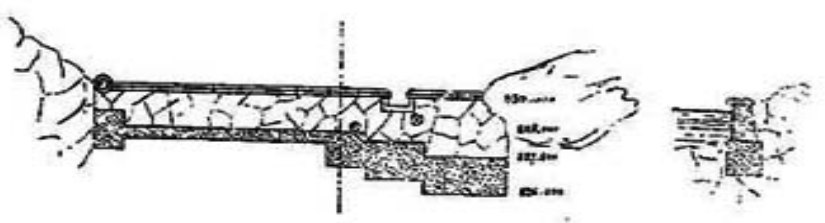

Barragem 
Deterioração: Ação do tempo (x) Atos de vandalismo (x)

Elementos que faltam: tijolos e parte do revestimento

Encanamento: $O$ escoamento da água ocorre por uma abertura inferior uma vez que o encanamento que o ligava ao aqueduto foi destruído

Diâmetro: $300 \mathrm{~mm}$

Espessura: $25 \mathrm{~mm}$

Material: $\mathrm{O}$ encanamento de ferro está revestido com uma camada de $170 \mathrm{~mm}$ de concreto

Deterioração : Ação do tempo (X) Atos de vandalismo (X)

Elementos que faltam: parte da canalização

Iconografia: Detalhes da Planta da Repartição Técnica de Águas e Esgotos $-1^{\text {a }}$

Divisão - Serviços de captação realizados na Serra da Cantareira durante o ano de 1894 - Escala 1:200 Acervo Arquivo do Estado de São Paulo

OBS. Grafia conforme o original

Fotos P. Doumet de 1894 - Acervo Particular

\subsubsection{Represa do Bispo}

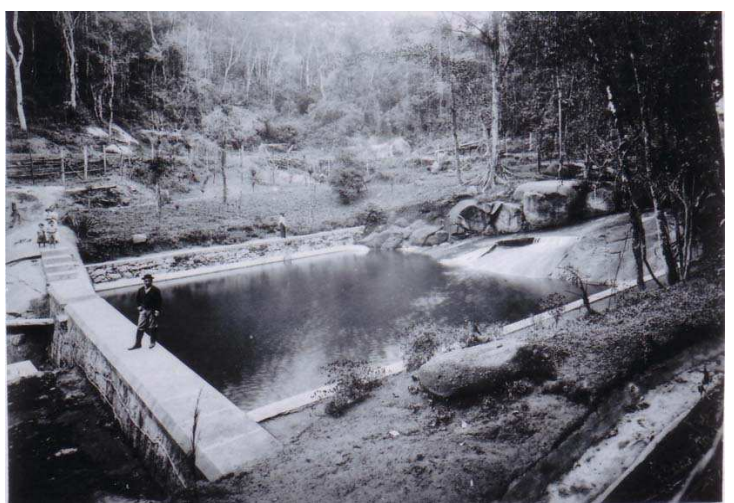

Foto P. Doumet 1894

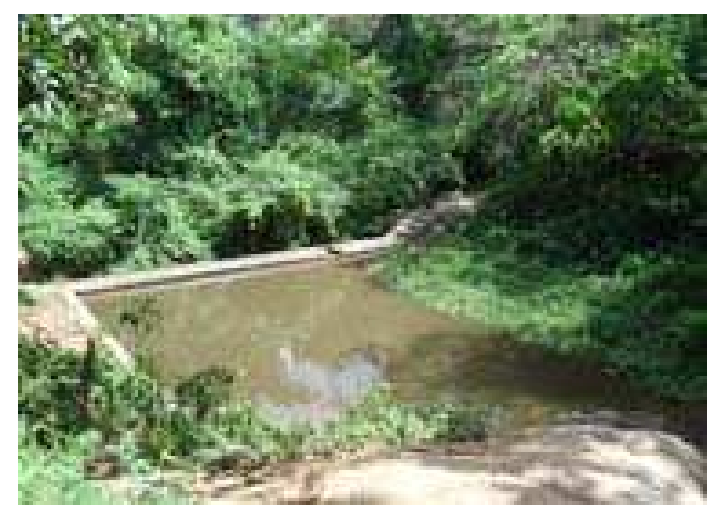

Foto 2006

Localização: S $23^{\circ} 26^{\prime} 37^{\prime \prime}$ W $46^{\circ} 39^{\prime} 25.8^{\prime \prime}$

Altitude: $826 \mathrm{~m}$

Meio de acesso: Estrada da Vista Alegre

Dimensões Gerais: 17,50 m de frente com 17,60 m de parede lateral. 


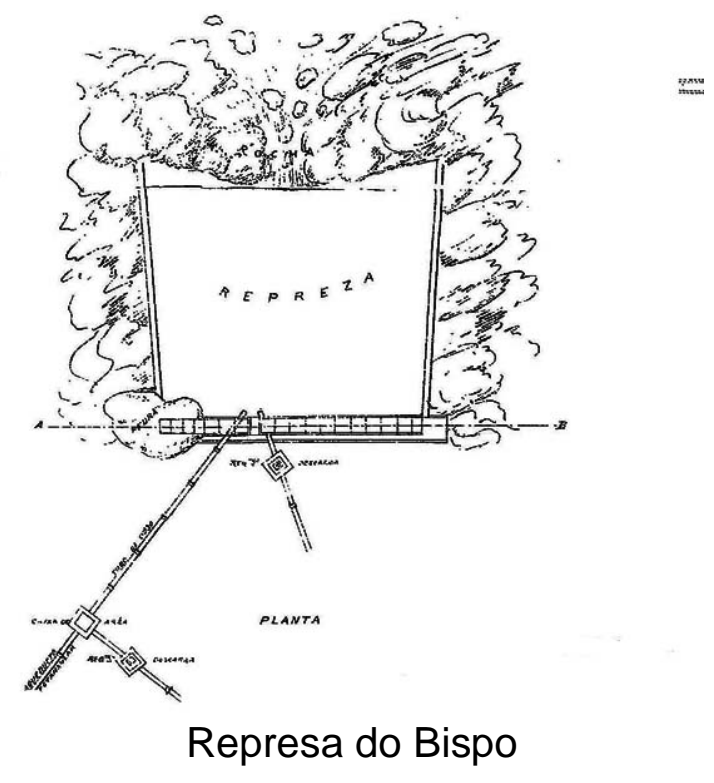

Capacidade de distribuição em 24 h: 1.200 .000 litros Materiais da estrutura: cimento $[x]$ concreto $(X)$ pedra $(X)$ Denominação do imaginário popular: piscinão

Descrição Geral: Barragem formada por blocos de granito de $950 \mathrm{~mm}$ de largura por $1 \mathrm{~m}$ de comprimento, cortados simetricamente, arrumados e dispostos em alinhamento horizontal.

Data: 1893.

Capacidade de distribuição em 24 h: 1.200 .000 litros

Propietário: Próprio Estadual

\section{DIAGNÓSTICO DO CONJUNTO}

Estado de conservação: Bom

Em funcionamento: Sim [ ] Não [x ]

Desativado mas operacional

Risco de destruição: A médio prazo

Natureza da deterioração: Atos de vandalismo

Elementos que faltam: parte da barragem

Medida de proteção que deve ser tomada: Desassoreamento, limpeza da vegetação, impedir o acesso, efetuar restauro e maior fiscalização

Observações:

Detalhamento: 


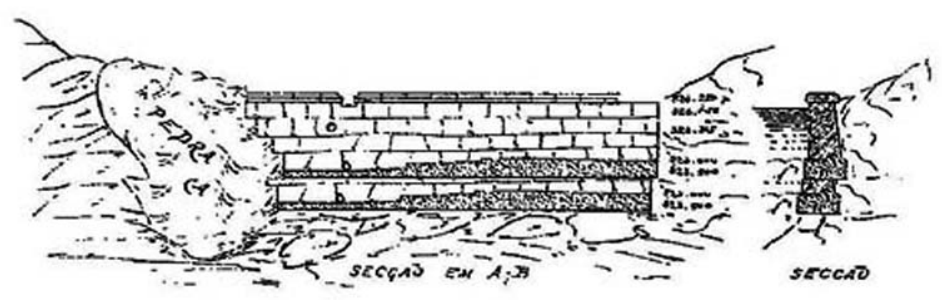

Barragem

Deterioração: Ação do tempo (x) Atos de vandalismo (x) Elementos que faltam: tijolos e parte do revestimento

Encanamento: $\mathrm{O}$ escoamento da água ocorre por uma abertura inferior uma vez que o encanamento que o ligava ao aqueduto foi destruído

Diâmetro: A represa estava cheia impedindo que as medidas fossem feitas

Deterioração : Ação do tempo $(X)$ Atos de vandalismo $(X)$

Iconografia: Detalhes da Planta da Repartição Técnica de Águas e Esgotos $-1^{\text {a }}$ Divisão - Serviços de captação realizados na Serra da Cantareira durante o ano de 1894 - Escala 1:200 Acervo Arquivo do Estado de São Paulo OBS. Grafia conforme o original

Álbum fotográfico P. Doumet de 1894 - Acervo Escola Politécnica - USP

Represas situadas à direita da Avenida Santa Inês, sentido Mairiporã.

\subsubsection{Represa do Guaraú}

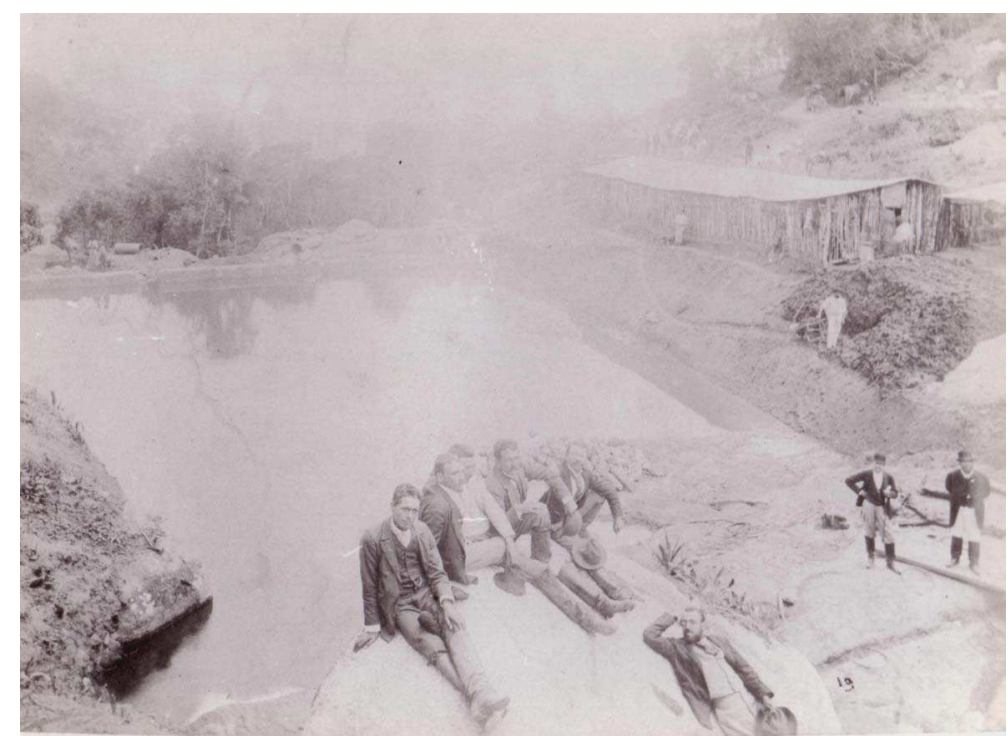

Foto P. Doumet 1893 Acervo Arquivo do Estado 


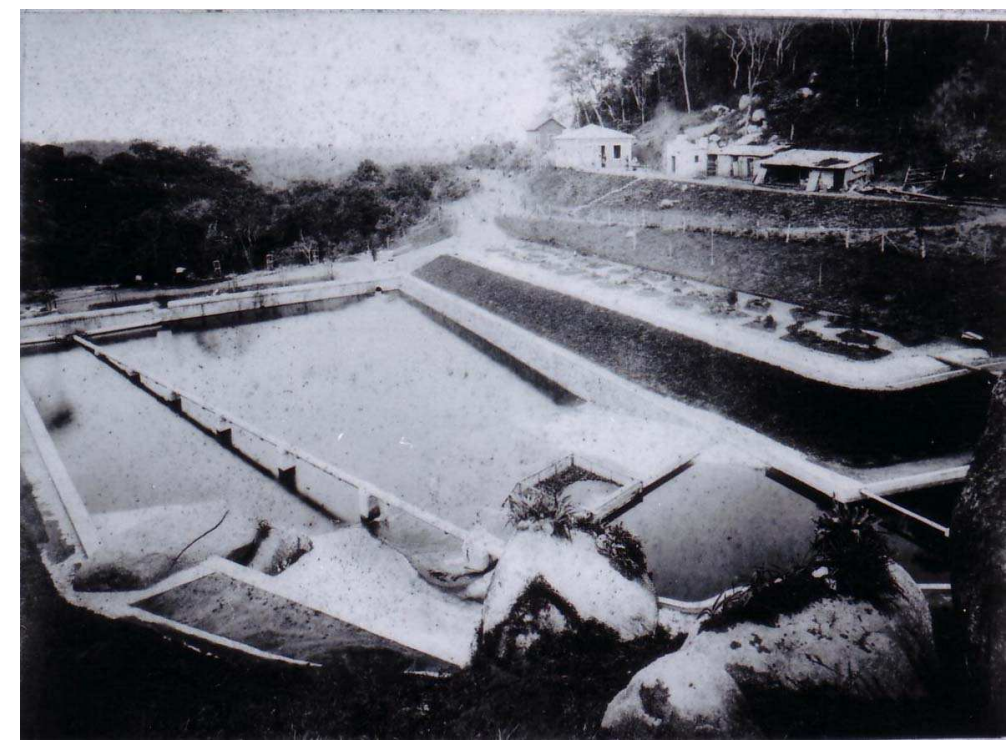

Foto P. Doumet 1894 Acervo Escola Politécnica

Localização: S $23^{\circ} 26^{\prime} 20.03^{\prime \prime}$ W $46^{\circ} 38^{\prime} 51.15^{\prime \prime}$

Altitude: $820 \mathrm{~m}$

Bairro: Pedra Branca

Meio de acesso: Estrada de Santa Inês

Dimensões Gerais:

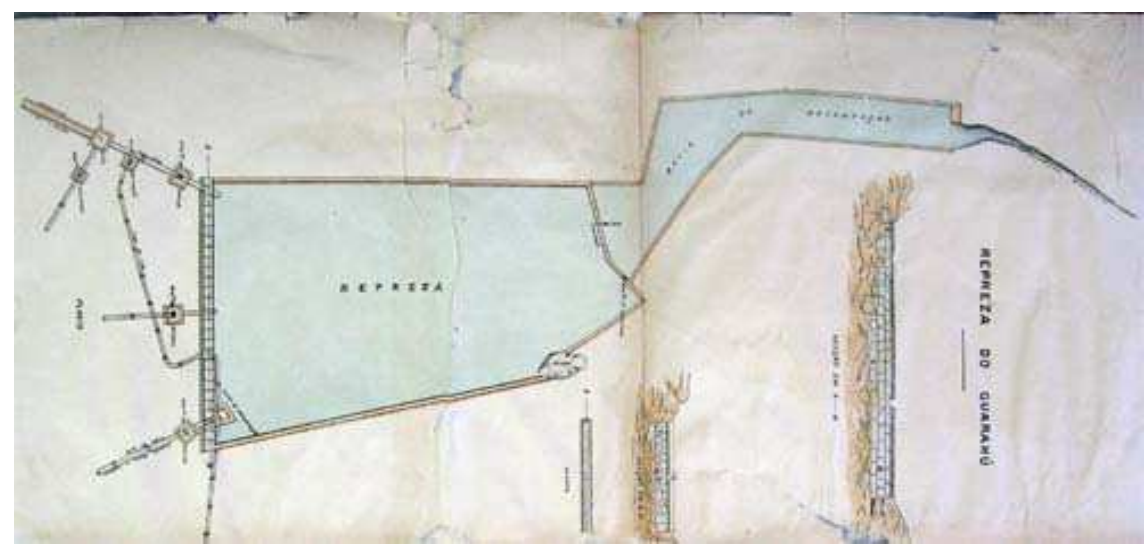

Planta original da Represa do Guaraú

\section{- Nota histórica}

Até Agosto de 1893, a Superintendência de Obras, projetava levar um encanamento de $600 \mathrm{~mm}$ ao reservatório de Acumulação, onde convergiam as águas captadas do Toucinho, Guatemy e do Cassununga, destinadas ao abastecimento da cidade. Porém, naquele mês o engenheiro Bernardino Salomé de Queiroga, resolveu que a canalização somente seria implantada até o Guaraú, conseguindo com o acréscimo de apenas 500 metros de tubos, eliminar sete 
quilômetros de aqueduto, o que seria um desperdício uma vez que até 0 Reservatório de Acumulação, não existia mais nenhum manancial.

O encanamento de $600 \mathrm{~mm}$ de diâmetro, que conduzia as águas da represa do Guaraú onde se reuniam com as deste manancial as do Manino, Itaguassu, Olaria, Bispo e Tanque, total de 11.600 .0000 litros, entroncavam-se por uma linha de tubos de $300 \mathrm{~mm}$ que dele derivava, indo até a rua Bento Freitas, esquina da Rua Major Sertório, na linha de distribuição geral que atravessava a Sete de Abril, espalhando-se em toda a rede que abastecia a zona comercial e central da cidade, até pouco acima do Largo da Sé, os bairros da Consolação e parte de Santa Efigência, Luz e Bom Retiro.

No final de 1893, estava pronta a represa do Guaraú, ponto de partida da canalização de $600 \mathrm{~mm}$, que transportava para a Capital as águas dos seguintes mananciais:

Guaraú com volume de 2.500 .000 litros:

\begin{tabular}{|c|c|c|c|c|}
\hline Tanque & " & “ & “ & 700.000 \\
\hline Bispo & “ & “ & “ & 1.200 .000 \\
\hline Olaria & “ & $“$ & “ & 600.000 \\
\hline Itaguassú & “ & $“$ & “ & 5.000 .000 \\
\hline Manino & “ & $"$ & “ & 1.600 .000 \\
\hline \multicolumn{3}{|l|}{ Volume } & & 11.600 .000 \\
\hline
\end{tabular}

No início de 1894 achavam-se captados os mananciais do Guaraú e do Bispo, fornecendo o volume de 3.700 .000 litros, e estavam em construção o aqueduto principal em direção ao Itaguassú e a represa do Tanque.

A 24 de Abril foi inaugurada toda a extensão do conduto principal até 0 Itaguassu, começando as águas deste manancial a serem aproveitadas no abastecimento da cidade, juntando-se às dos córregos da Olaria, Bispo, Tanque e Guaraú, de onde saia o cano de 600 mm para a Capital.

A represa do Guaraú sofreu várias modificações ao longo do tempo. Em 1904, foi aproveitada para a instalação de um clarificador, e numa cota acima, instalaram uma nova represa. Todo o complexo foi destruído na década de 1970, com a construção da atual ETA, Estação de Tratamento de Água do Guaraú. 


\section{Bibliografia}

- Relatórios da Repartição de Águas e Esgotos e da Secretaria de Agricultura.

- Documentação do Arquivo do Estado de São Paulo

\section{Iconografia}

Detalhes da Planta da Repartição Técnica de Águas e Esgotos - $1^{\text {a }}$ Divisão Serviços de captação realizados na Serra da Cantareira durante o ano de 1894 Escala 1:200 Acervo Arquivo do Estado de São Paulo OBS. Grafia conforme o original

Álbum fotográfico P. Doumet 1893 - Acervo Arquivo do Estado de São Paulo Álbum fotográfico P. Doumet de 1894 - Acervo Escola Politécnica - USP Fotos P. Doumet de 1894 - Acervo Particular

\subsubsection{Represa do Cassununga}

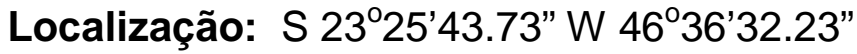

Altitude: $791 \mathrm{~m}$

Bairro: Cachoeirinha

Meio de acesso: Subindo a Avenida Nova Cantareira em direção a Mairiporã, fica à direita, assim que se entra na Avenida Senador José Ermírio de Moraes

Dimensões Gerais:

Capacidade de distribuição em 24h: 2.000 .000 litros

Materiais da estrutura: Pedra $[x]$ tijolo $[x]$ concreto $[x]$ cimento $[x]$ ferro

Outros:

Descrição geral:

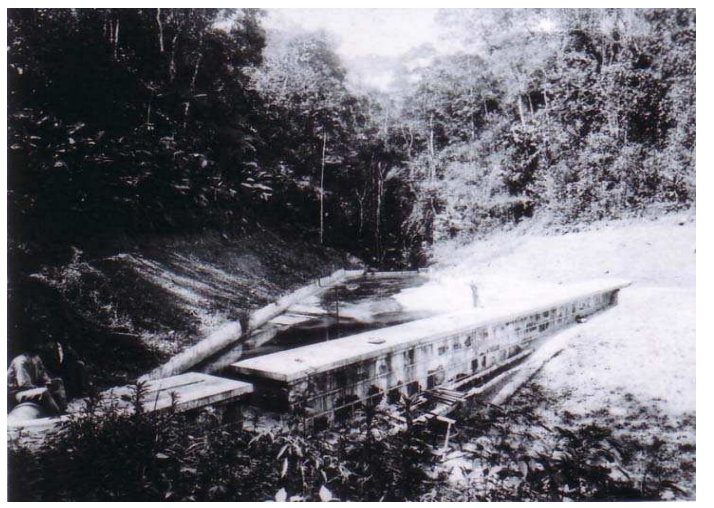

Foto P. Doumet 1894

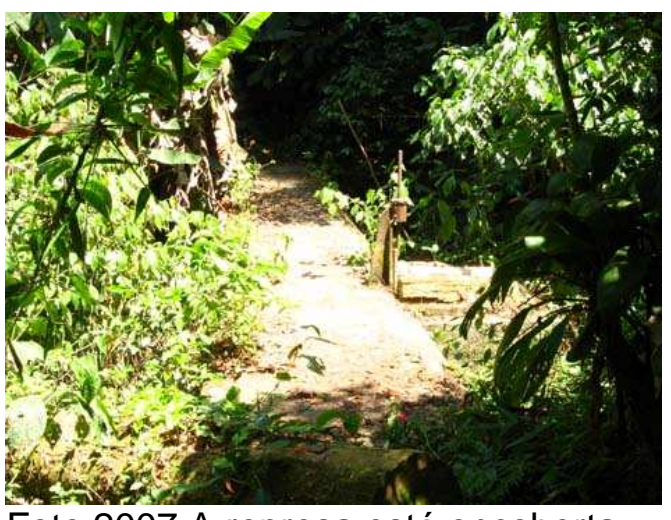

Foto 2007 A represa está encoberta pela vegetação

\section{- Nota histórica}

Segundo Relatório de 1893, 229 tubos de ferro fundido, parte do material para as obras tinham sido levados pela Companhia Cantareira que não terminou o serviço alegando dificuldade para transportá-los. 
No entanto, a urgência em executar a canalização do Cassununga até o Reservatório de Acumulação exigiu um aqueduto em forma circular com $500 \mathrm{~mm}$ de diâmetro constituído internamente por uma camada de concreto e superiormente, por alvenaria de tijolos cuneiformes.

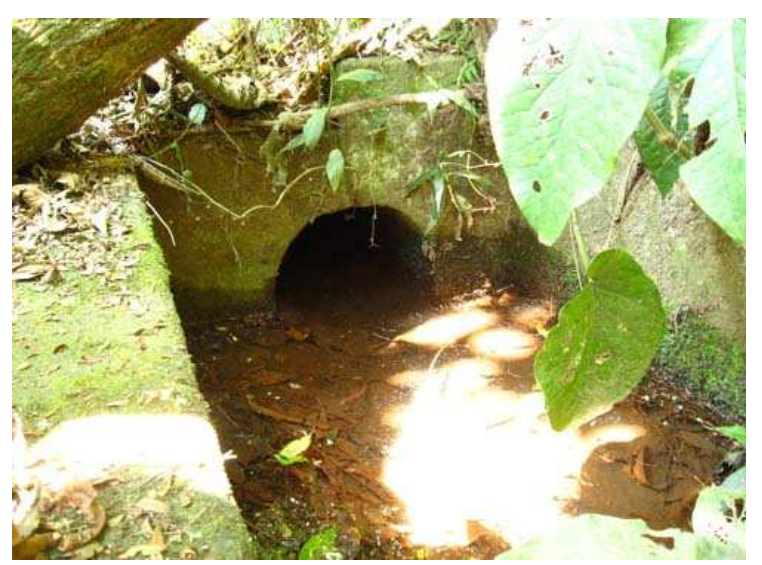

Foto 2007 aqueduto em alvenaria 500mm de diâmetro

Da represa, parte um aqueduto com declividade de $1 \mathrm{~cm}$ e extensão de 304 metros, para a travessia do Cassununga, um sifão de 88 metros de canos de ferro com 300 mm de diâmetro que conduze as águas até uma caixa.

Daí, para atravessar uma grota foram utilizados $80 \mathrm{~m}$ de canos de $400 \mathrm{~mm}$ dispostos sobre pilares de alvenaria com tubos de $400 \mathrm{~mm}$ servindo de colunas.

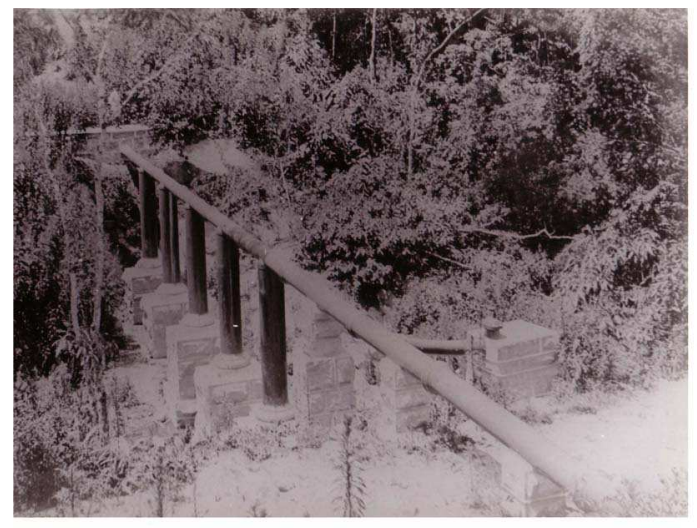

Foto P. Doumet 1894 Aqueduto em tubos de ferro

As águas do Cassununga, Campo Redondo e Engordador, transportadas por uma canalização de $300 \mathrm{~mm}$ para os bairros altos eram distribuídos de dois modos: Diretamente, isto é, partindo do próprio encanamento condutor das águas 
mencionadas e Indiretamente, quando recolhidas ao reservatório da Liberdade, depois de atravessar um regulador automático.

A distribuição direta era limitada aos pontos de altitude superior a 800 metros seguindo pela Avenida Paulista, Rua da Consolação com ramificações para as ruas de Santo Amaro, Bela Cintra, Paraíso, Vergueiro e aos bairros próximos da Vila Mariana e Saúde.

Da distribuição indireta faziam parte os bairros da Liberdade, Cambuci, Bela Vista, Consolação, Higienópolis e Pacaembu.

A linha principal com $300 \mathrm{~mm}$ de diâmetro, saindo do Reservatório da Liberdade, seguia pelas ruas Vergueiro, São Joaquim, Humaitá, Tamandaré, Pires da Mota e Galvão Bueno.

Proprietário: Próprio Estadual

\section{DIAGNÓSTICO DO CONJUNTO}

\section{Estado de conservação:}

Em funcionamento: Sim [ ] Não [x]

Desativado mas operacional: Sim [ ] Não [x]

REGULAR [x ]

Risco de destruição: A médio Prazo [x ]

Medida de proteção que deve ser tomada: Desassoreamento ( $x$ ) limpeza da vegetação (x ) Maior fiscalização (x ) Restauro (x)

Observações:

Detalhamento:

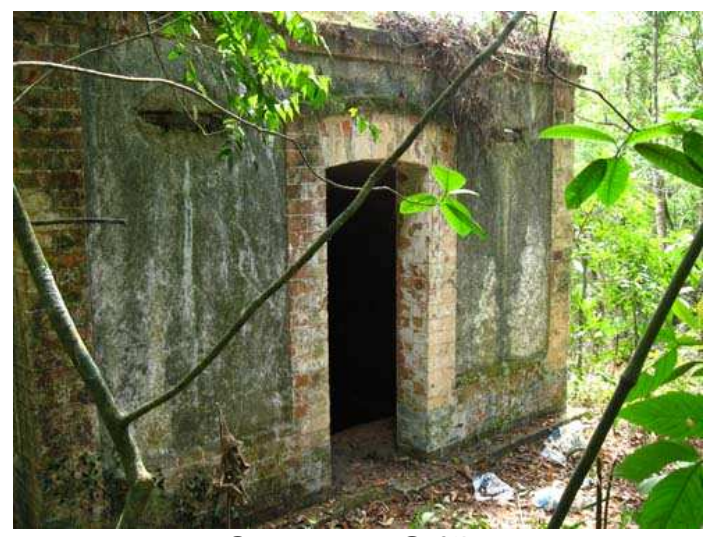

Caixa do Sifão

Em 10 de outubro de 2007, devido à vegetação, não é possível visualizar o aqueduto. A porta de proteção foi retirada. 


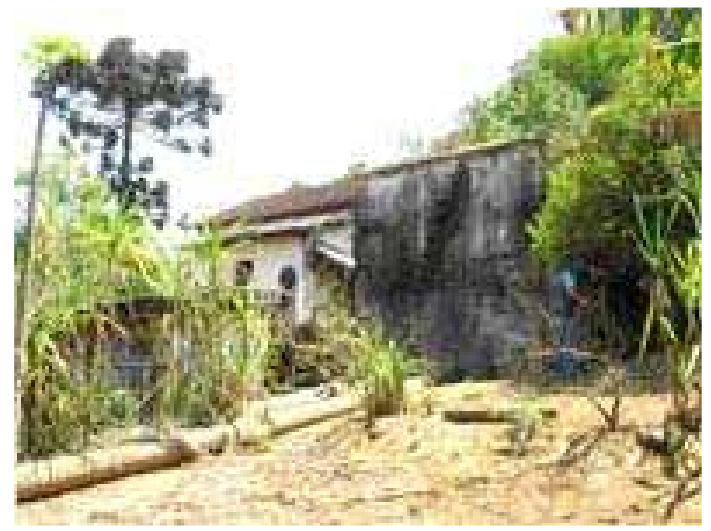

Segunda Caixa do Sifão

Ao lado, residência do Guarda Parque. Logo abaixo, ficam os encanamentos que saem da Caixa e conduzem as águas do Cassununga através de aqueduto até o Reservatório de Acumulação. Outubro de 2007.

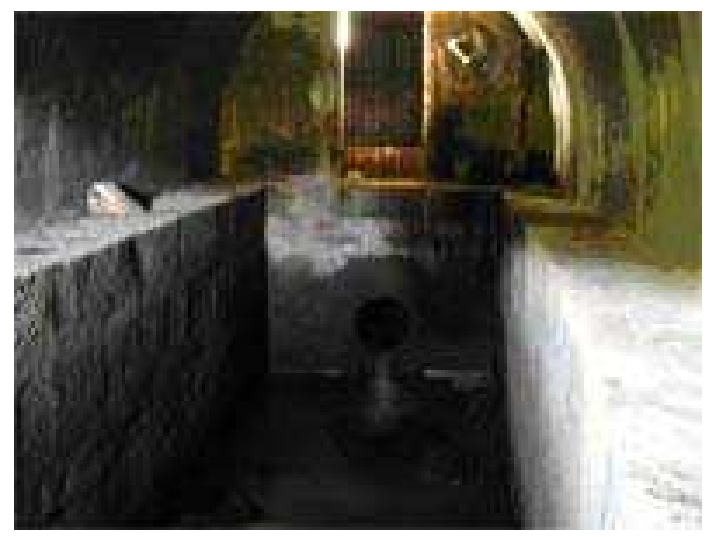

Sifão (Vista interna)

Segunda Caixa do Sifão do Cassununga. Vista do interior a partir dos fundos. 10 de outubro de 2007. Pode-se ver a porta que na outra caixa foi retirada.

Aqueduto em ferro fundido: 


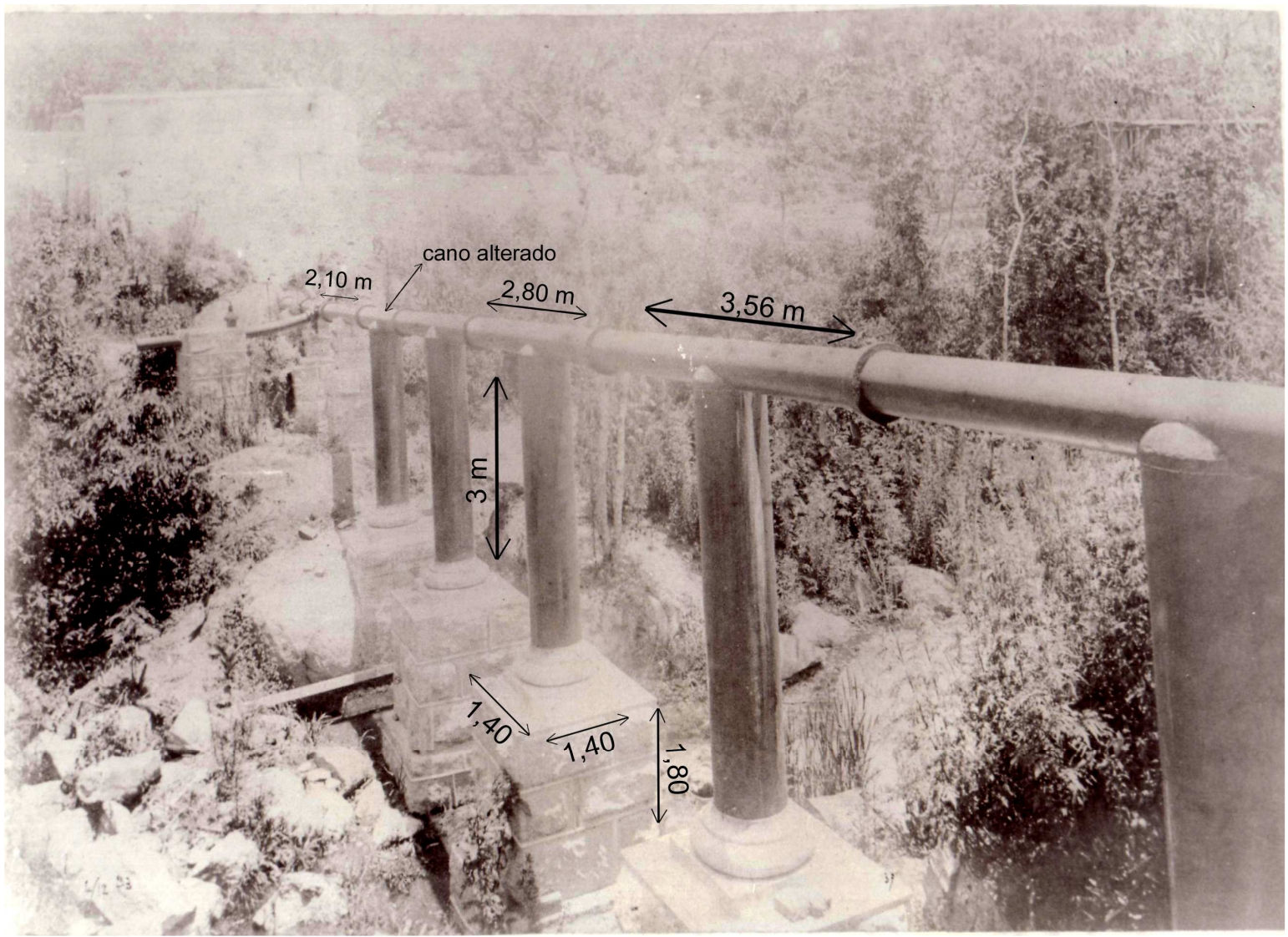

P. Doumet 1894 Acervo Particular. O encanamento parte da Segunda Caixa do Sifão, atravessa uma grota, e se encontra com a outra Caixa, onde recebe a contribuição das águas de um pequeno riacho, e daí segue para o Reservatório de Acumulação.

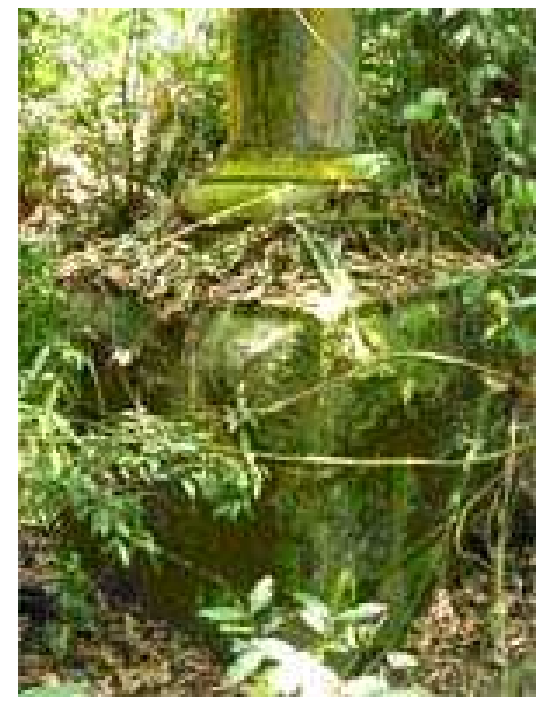

Foto 2007 - Detalhe de uma das pilastras

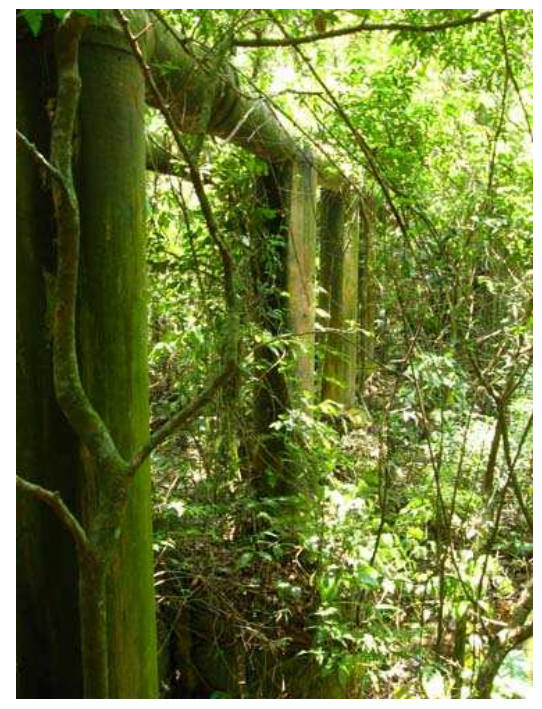

Foto 2007 - Aqueduto encoberto pela Vegetação 


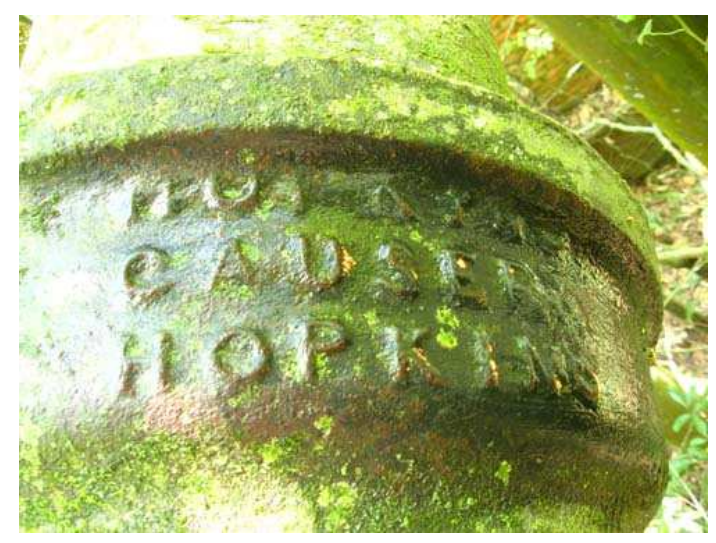

Foto 2007 com a inscrição do fabricante

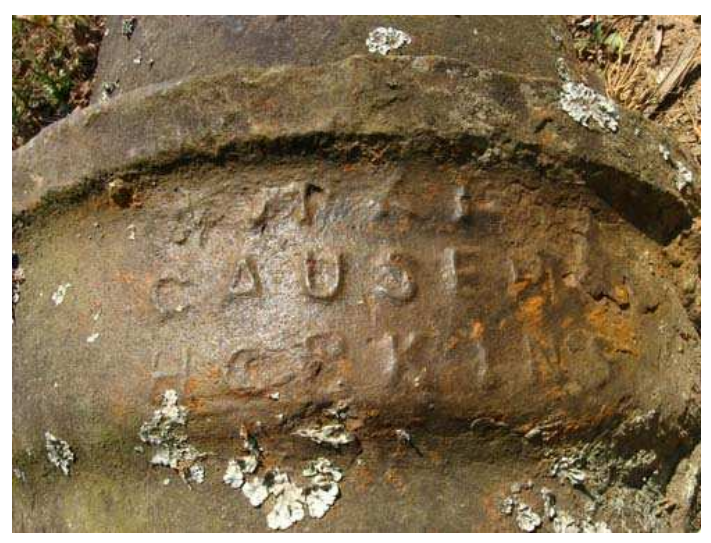

Foto 2007

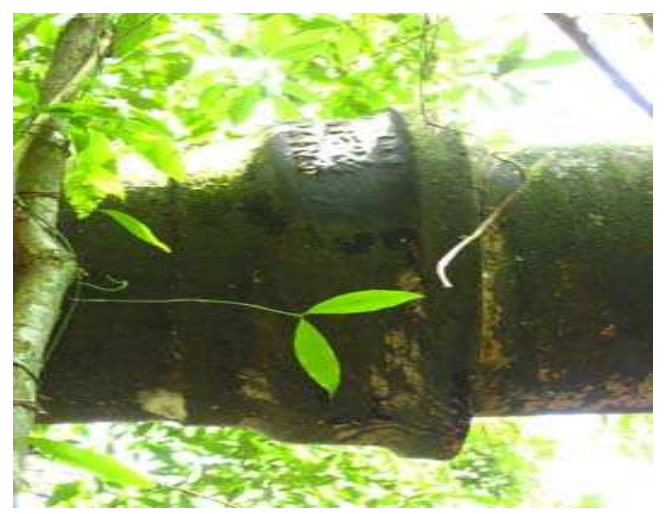

Aqueduto aéreo Hopkins

Em todo o percurso o encanamento apresenta o nome do fabricante: Causer

Deterioração: Ação do tempo (x ) Atos de vandalismo ( )

Obs: Com relação ao aqueduto, está parcialmente coberto pela vegetação e sofre ameaça constante, pois está em área de fácil acesso, e o seu material, ferro, pode ser vendido facilmente no mercado. Reforçando esta preocupação, em inquérito oral realizado com o Sr Elói, guarda parque do local, este relatou que no começo deste ano, autuou marginais que tentavam retirar o encanamento durante a madrugada.

Comparando as fotos recentes com as de 1893 e 1894 pode ser observado a presença de um novo aqueduto em paralelo, provavelmente construído na década de sessenta, não foi encontrado qualquer sinal do fabricante constando, a data de fabricação:1961. Em outra área do Cassununga o encanamento foi furtado, restando apenas, os pilares de sustentação. 


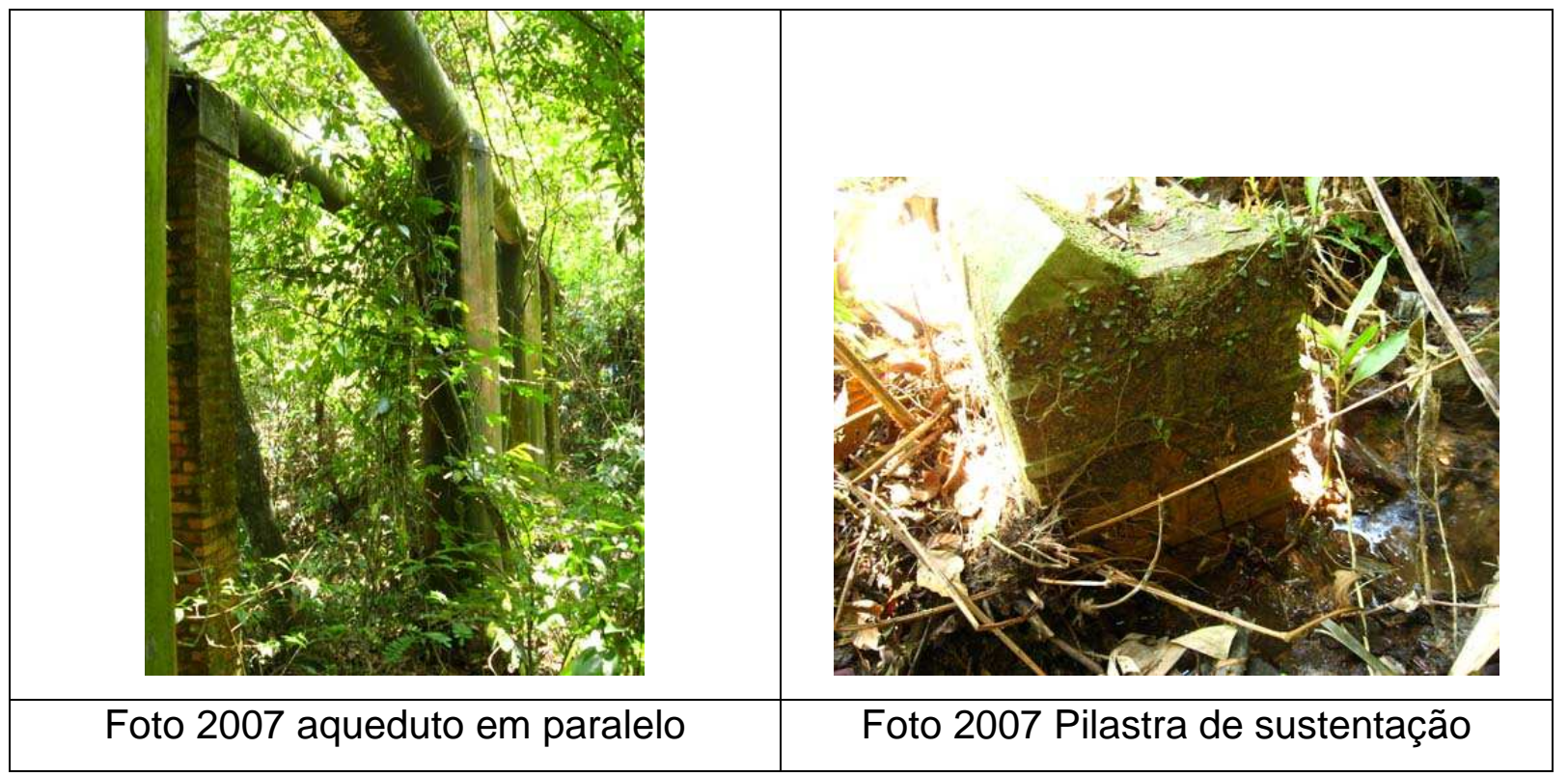

Documentação de referência:

\section{Bibliografia:}

- Relatório apresentado ao Presidente do Estado de São Paulo pelo Dr Jorge Tibiriçá, Secretário de Estado dos Negócios da Agricultura, Comércio e Obras Públicas em, 04 de abril de 1893, Rio de Janeiro, G. Leuzinger \& Filhos, 1893.

- Documentação do Arquivo do Estado de São Paulo

- Fotos P. Doumet de 1894 - Acervo Particular

\subsubsection{Represas do Engordador}

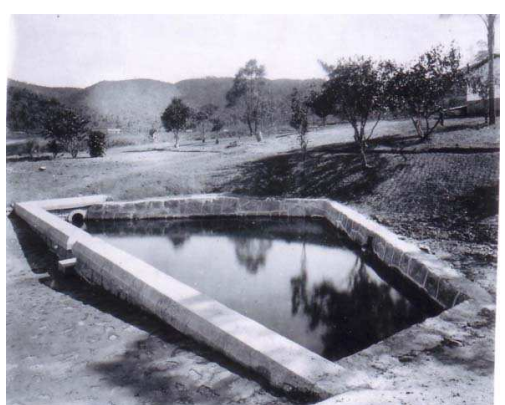

Foto P. Doumet 1894

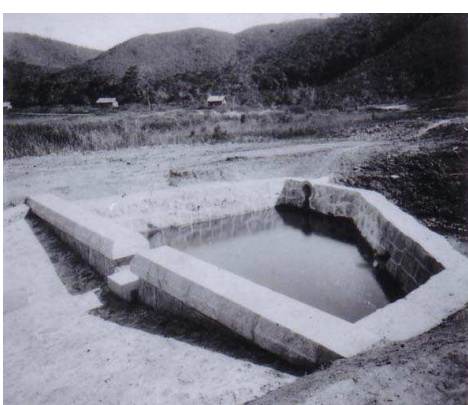

Foto P. Doumet 1894

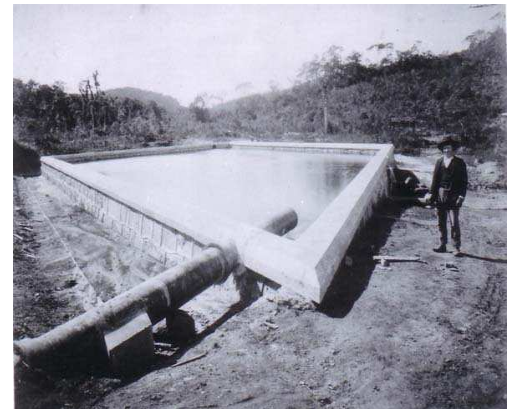

Foto P. Doumet 1894

Localização: $23^{\circ} 23^{\prime \prime} 36.92 S$ 46³'37.13"

Altitude: $905 \mathrm{~m}$ 
Núcleo: Engordador

Meio de acesso: Avenida Sezefredo Fagundes no

Dimensões Gerais

Capacidade de distribuição em 24h: 3.800 .000 litros

Materiais da estrutura: Pedra $[x]$ tijolo $[x]$ concreto $[x]$ cimento $[x]$

- Nota histórica

A partir de 1893 começaram a ser construídos pequenos tanques de captação, que um ano depois, mandavam suas águas para a Caixa do Gonçalves e daí seguiam para o Cassununga.

Em 1904, logo abaixo dessas represas, foi construída uma barragem para armazenar aproximadamente 500.000 metros cúbicos, e instalado-se uma estação de recalque com uma bomba inglesa a vapor.

Em campo foram encontrados equipamentos importados provavelmente da Bélgica e da Inglaterra.

\section{Diagnóstico do conjunto}

Estado de conservação:

Em funcionamento: Sim [ ] Não [X ]

Desativado mas operacional: Sim [ ] Não [ ]

BOM [ ] REGULAR [X] RUIM [ ]

Risco de destruição iminente: [ ] A médio Prazo [x ]

Medida de proteção que deve ser tomada: Desassoreamento (x) limpeza da vegetação (x) Maior fiscalização ( ) Restauro (x)

Observações: A maior parte da infra-estrutura de 1894 está encoberta pela vegetação.

Detalhamento:

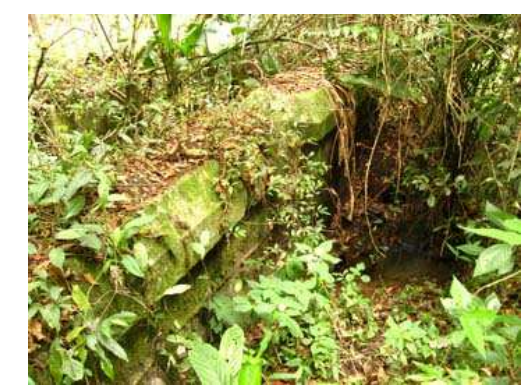

Foto 2007 represa encoberta pela vegetação

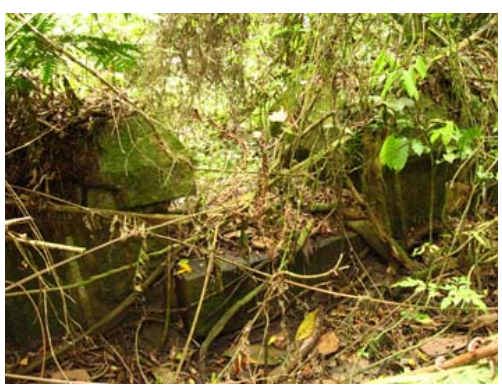

Foto 2007 represa encoberta pela vegetação 


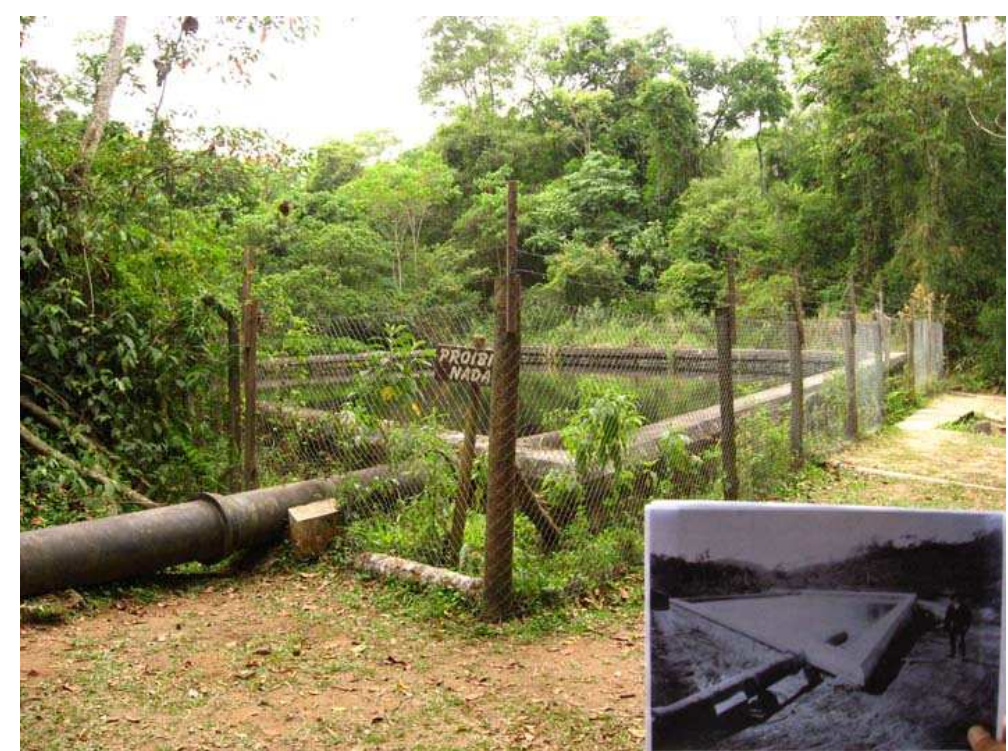

Foto 2007 tanque de 1894

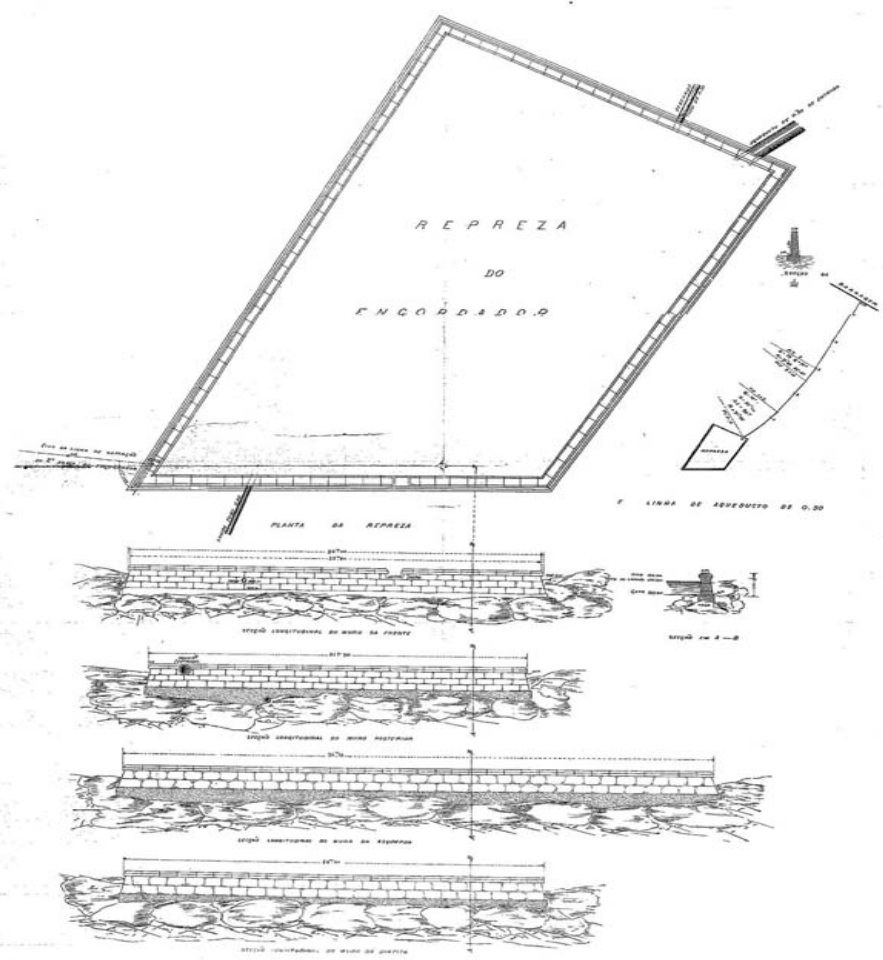

Represa do Engordador 
Encanamentos:

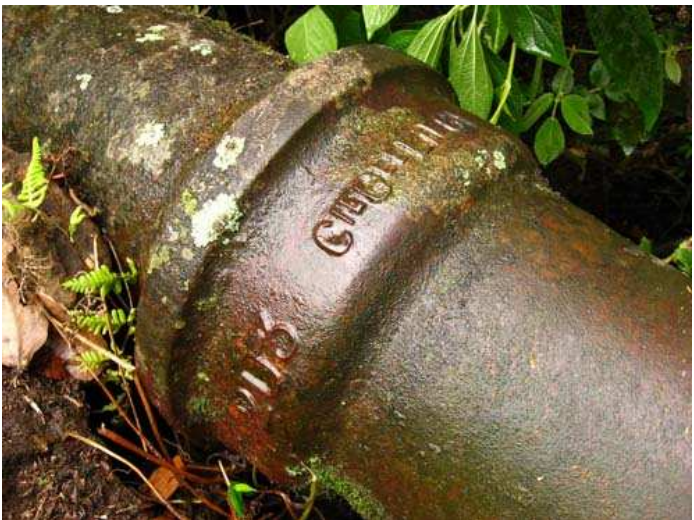

Foto 2007

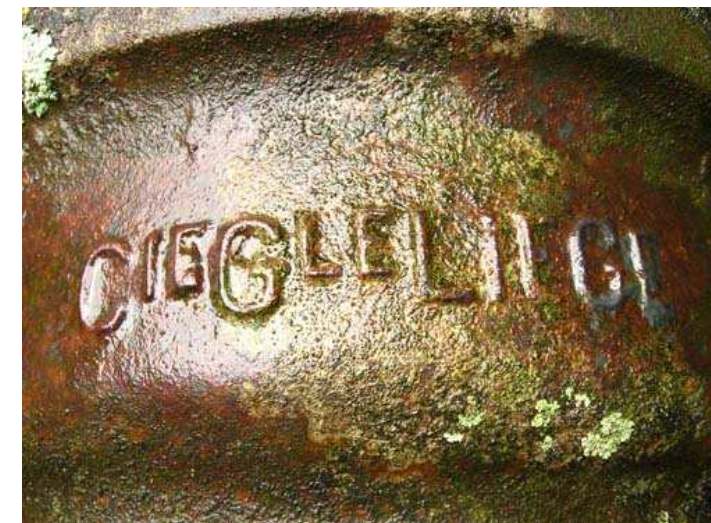

Foto 2007

Diâmetro: $300 \mathrm{~mm}$

Material: ferro fundido

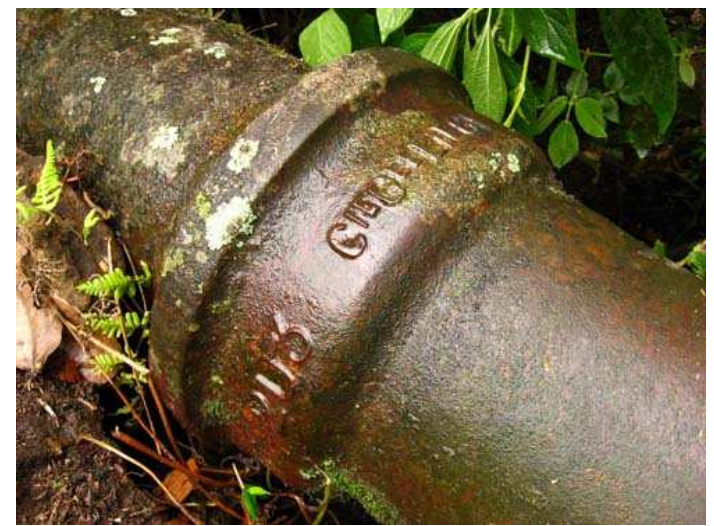

Foto 2007

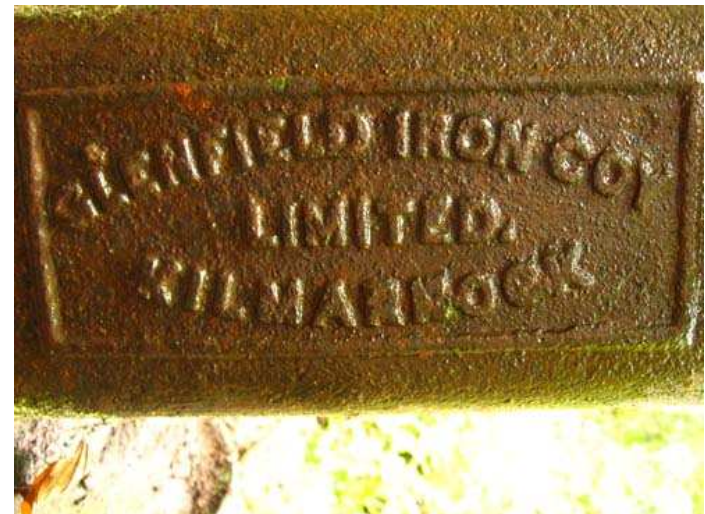

Placa de registro da válvula de encanamento

Documentação de referencia/localização do acervo:

\section{Bibliografia:}

- Relatórios da Repartição de Águas e Esgotos e da Secretaria de Agricultura.

- Documentação do Arquivo do Estado de São Paulo

\section{Iconografia:}

- Detalhes da Planta da Repartição Técnica de Águas e Esgotos - $1^{\text {a }}$ Divisão Serviços de captação realizados na Serra da Cantareira durante o ano de 1894 - Escala 1:200 Acervo Arquivo do Estado de São Paulo Obs.: Grafia conforme o original.

- Álbum fotográfico P. Doumet de 1894 - Acervo Escola Politécnica - USP

- Fotos P. Doumet de 1894 - Acervo Particular 


\subsubsection{Aqueduto do Matheus}

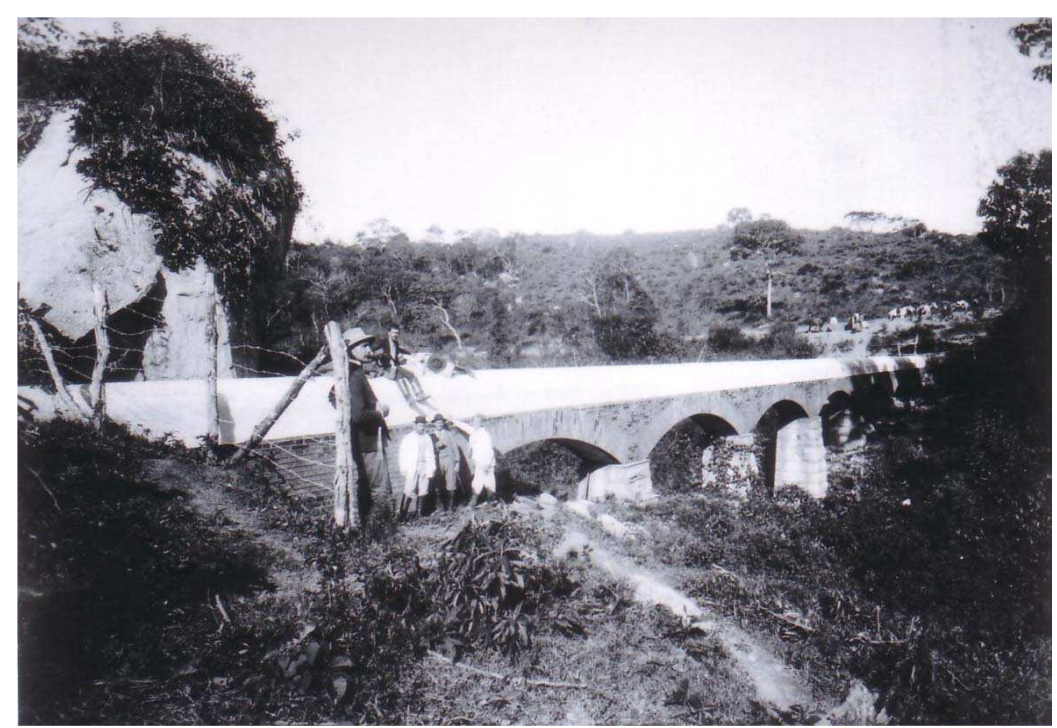

Foto P. doumet 1894

Localização: S: $23^{\circ} 26^{\prime} 48.1^{\prime \prime}$ W: $46^{\circ} 40^{\prime} 04.2^{\prime \prime}$ Entre a represa do Ytaguassu e a do Bispo.

Altitude: $838 \mathrm{~m}$

Meio de acesso: Estrada da Vista Alegre

Dimensões Gerais: Possui uma extensão de $60 \mathrm{~m}$ de extensão com 7, $5 \mathrm{~m}$ de altura e $5 \mathrm{~m}$ de largura.

Materiais da estrutura: Pedra $[x]$ tijolo $[x]$ concreto [ ] cimento $[x]$

\section{Nota Histórica:}

Os aquedutos partem de um ponto central dos mananciais, recolhem as águas e as transportam livremente para os reservatórios, diretamente, pela ação da gravidade.

No século XIX, eram preferidos quando os engenheiros consideravam pequena a diferença de nível entre os pontos de partida e de chegada em relação à distância horizontal, sendo o sistema mais econômico quando queriam reduzir os custos com acabamento em alvenaria, tendo sido adotado para transportar as águas dos reservatórios da Cuca ao Guaraú passando pelo córrego do Bispo.

Em Abril de 1893, estava concluída a primeira etapa de instalação do aqueduto com $3.500 \mathrm{~m}$ de extensão, com diâmetro de $600 \mathrm{~mm}$ entre o manancial do Bispo e o córrego do Itaguassu. Foi construído em alvenaria de concreto no radier, em meia seção, sendo a parte superior feita de tijolos com cimento, revestido 
externamente com uma camada de argamassa de cimento e areia, de dois centímetros de espessura.

Normalmente a travessia desses vales era feita com sifão, que é um conduto forçado, mas como no trecho compreendido entre a Cuca e o Guaraú, havia pequena carga disponível de uma extremidade a outra da derivação, com exceção do trecho do Itaguassu, essa solução seria impraticável.

Surgiu a necessidade da construção de pilares de alvenaria de pedra e "ponte-aqueduto" ou arcadas que se eleva até ao nível da linha de carga, com declive que descia até $10 \mathrm{~cm}$ a cada quilômetro de sua extensão.

São poucos os ribeirões situados na Cantareira que se encontram identificados em cartas hidrográficas. Somente foi localizado o trecho que atravessa a grota do Matheus, uma vez que em inquérito oral com antigos guarda-parques, mostramos as fotos de 1894, e obtivemos a informação que estaria situado entre o Ytaguassu e o Bispo.

\section{Descrição Geral}

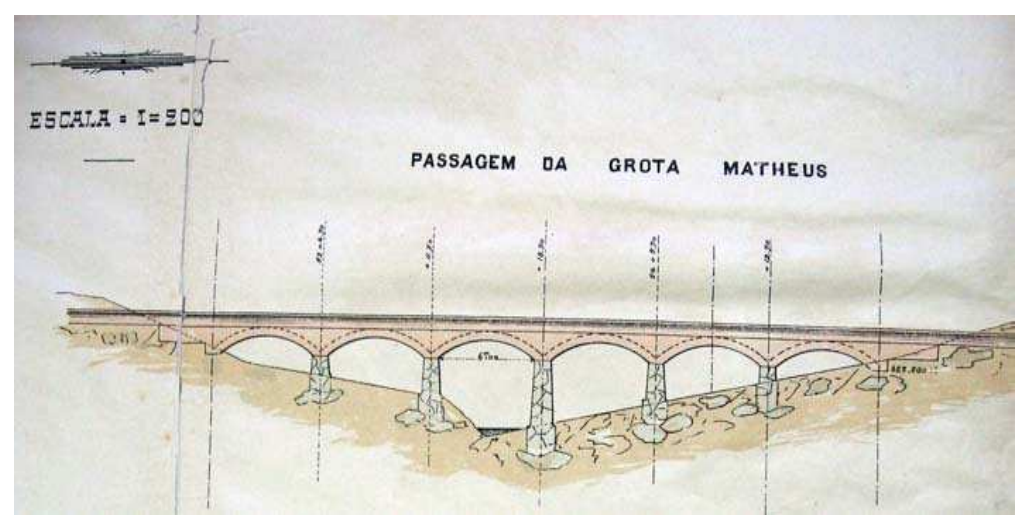

Planta original do aqueduto do Matheus 1894

\section{Nota histórica:}

Os aquedutos partem de um ponto central dos mananciais, recolhem as águas e as transportam livremente para os reservatórios, diretamente, pela ação da gravidade.

No século XIX, eram preferidos quando os engenheiros consideravam pequena a diferença de nível entre os pontos de partida e de chegada em relação à distância horizontal, sendo o sistema mais econômico, quando queriam reduzir os 
custos com acabamento em alvenaria, tendo sido adotado para transportar as águas dos reservatórios da Cuca ao Guaraú, passando pelo córrego do Bispo.

Em Abril de 1893, estava concluída a primeira etapa de instalação do aqueduto com $3.500 \mathrm{~m}$ de extensão, com diâmetro de $600 \mathrm{~mm}$ entre o manancial do Bispo e o córrego do Itaguassu. Foi construído em alvenaria de concreto no radier, em meia seção, sendo a parte superior feita de tijolos com cimento, revestido externamente com uma camada de argamassa de cimento e areia, de dois centímetros de espessura.

Normalmente a travessia desses vales era feita com sifão, que é um conduto forçado, mas como no trecho compreendido entre a Cuca e o Guaraú, havia pequena carga disponível, de uma extremidade a outra da derivação, com exceção do trecho do Itaguassu, essa solução seria impraticável.

Surgiu a necessidade da construção de pilares de alvenaria e "ponteaqueduto" ou arcada, que se eleva até ao nível da linha de carga, com declive que descia a $10 \mathrm{~cm}$ a cada quilômetro de sua extensão.

São poucos os ribeirões situados na Cantareira que se encontram identificados em cartas hidrográficas. Somente foi localizado o trecho que atravessa a grota do Matheus, que estava encoberto pela vegetação, uma vez que em inquérito oral com antigos guarda-parques, mostramos as fotos de 1894, e obtivemos a informação que estaria situado entre o Ytaguassu e o Bispo.

\section{Diagnóstico do conjunto:}

Estado de conservação:

Em funcionamento: Sim [ ] Não [x]

Desativado mas operacional: Sim [x ] Não [ ]

BOM [ ] REGULAR [x] RUIM [ ]

Risco de destruição Iminente: [ ] A médio Prazo [x]

Medida de proteção que deve ser tomada: Desassoreamento ( ) limpeza da vegetação (x) Maior fiscalização (x) Restauro (x) 


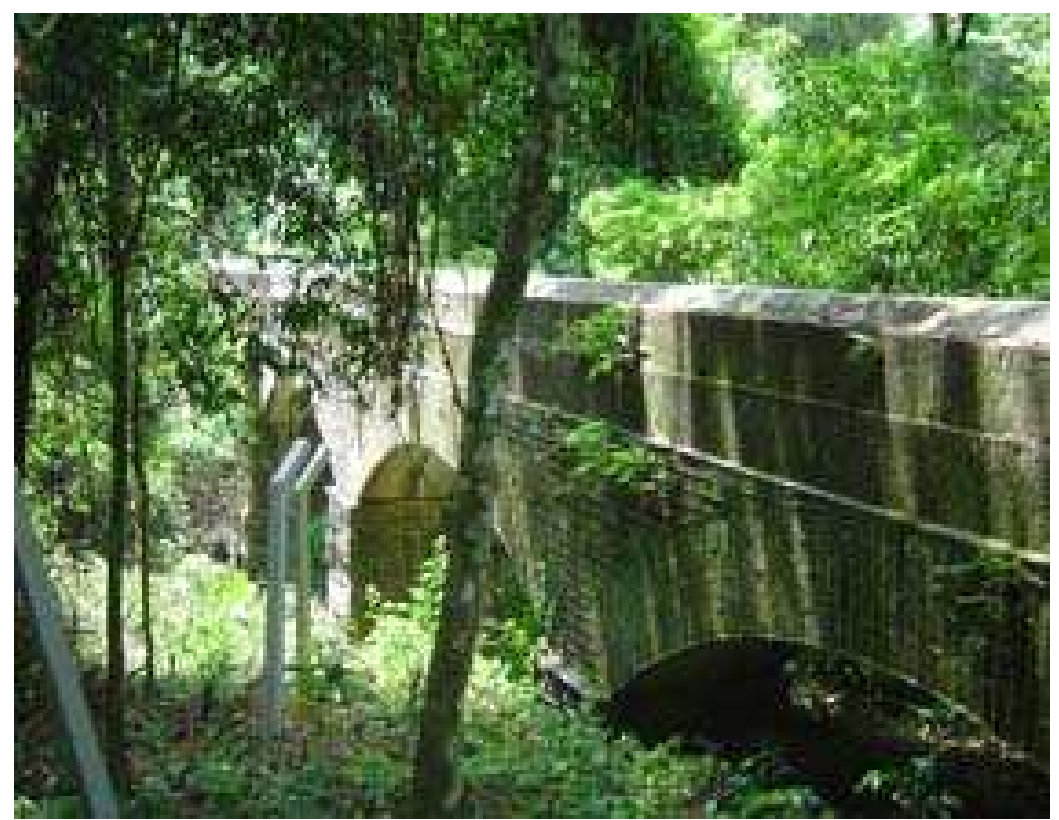

Foto 2006 A vegetação que encobria o aqueduto foi parcialmente retirada para a definição das divisas do parque.

Documentação de referência/localização do acervo:

\section{Bibliografia:}

- Relatórios da Repartição de Águas e Esgotos e da Secretaria da Agricultura anos 1893, 1894 e 1895.

\section{Iconografia:}

- Detalhes da Planta da Repartição Técnica de Águas e Esgotos $-1^{a}$ Divisão Serviços de captação realizados na Serra da Cantareira durante o ano de 1894 - Escala 1:200 Acervo Arquivo do Estado de São Paulo Obs.: Grafia conforme o original.

- Fotos P. Doumet de 1894 - Acervo Particular

\subsection{Caixa de Junção do Guapira}

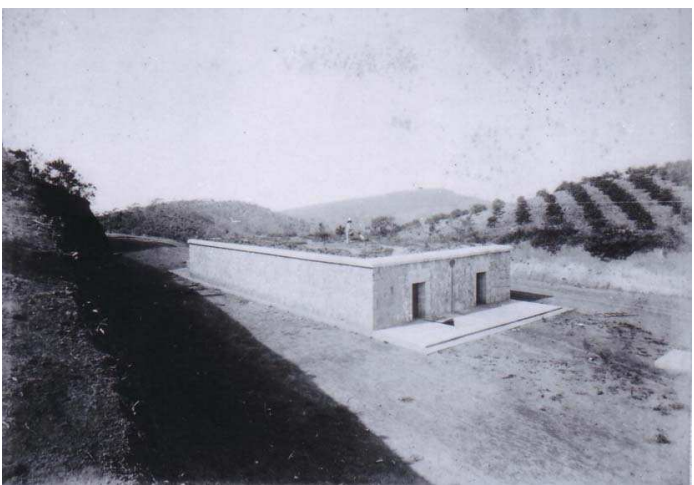

Foto P. Doumet 1894

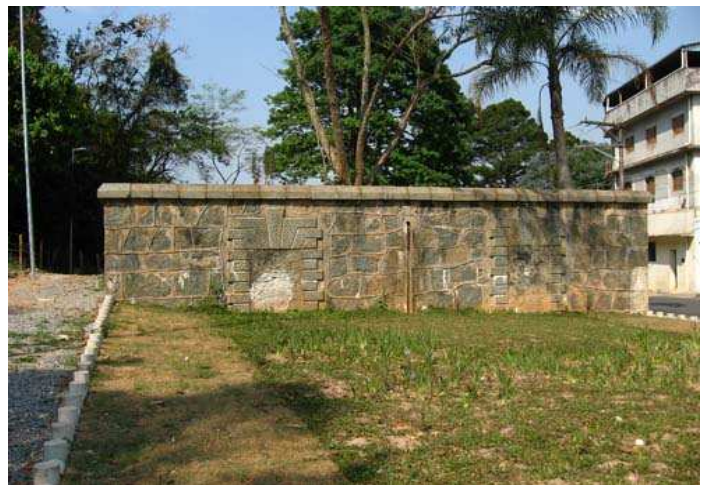

Foto 2007 
Localização: $23^{\circ} 26^{\prime} 29.42^{\prime \prime S} 46^{\circ} 36^{\prime} 58.62^{\prime \prime} \mathrm{W}$

Está situado fora dos limites do Parque Estadual da Cantareira

Altitude: 873,20

Bairro: Cachoeirinha

Meio de acesso: Avenida Nova Cantareira com a Avenida Senador José Ermiírio de Moraes

Materiais da estrutura: Pedra $[x]$ tijolo $[x]$ concreto $[x]$ cimento $[x]$ Descrição geral:

\section{Nota histórica:}

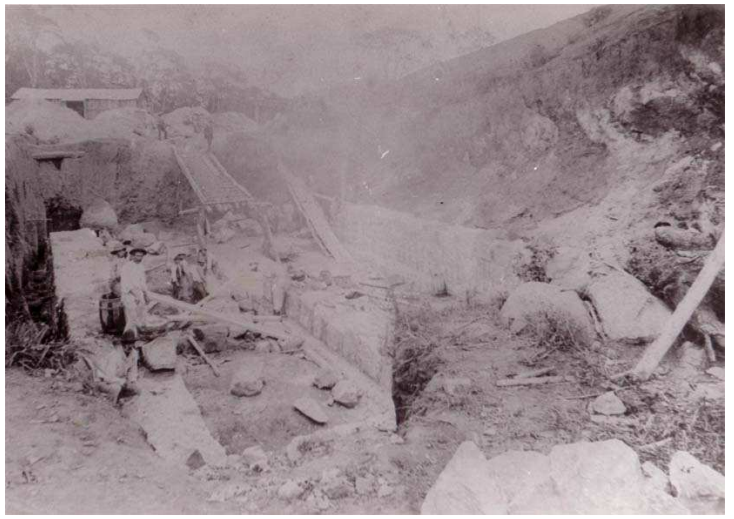

Foto P. Doumet 1893

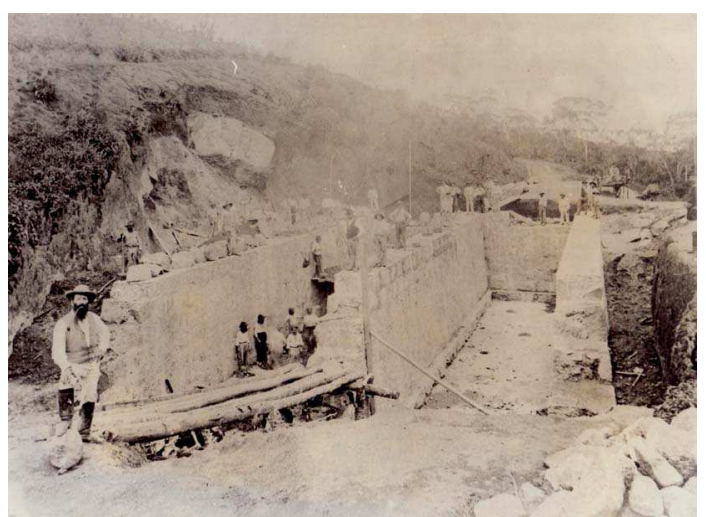

Foto P. Doumet 1893

Concluído em Agosto de 1894, deste reservatório partia uma canalização, com 300mm de diâmetro, para os bairros altos da Capital, com capacidade para armazenar até 500.000 litros, está situado a 600 metros de distância dos Reservatórios de Acumulação, e recebia as águas do aqueduto de $500 \mathrm{~mm}$ condutor do Cassununga e Engordador.

Segundo Relatório de 1894, foi construído pelo empreiteiro Miguel Prota, e compreende dois compartimentos, cada um com as dimensões $20 \mathrm{mX} 4 \mathrm{~m}$ e $45 \mathrm{X} 2,85$ constituindo dois vasos comunicantes, ligados individualmente por um encanamento de derivação e ao conduto mestre da distribuição. Os dois segmentos concorriam para o abastecimento diário da cidade, mas se um deles tivesse que ser esvaziado para a limpeza ou consertos, o outro fazia o serviço de distribuição. As paredes foram feitas de alvenaria de pedra com argamassa de cimento e fundo de concreto, porém, essa informação não pode ser confirmada em trabalho de campo, uma vez que atualmente se encontra totalmente lacrada.

Uso atual: Está desativada. 
Diagnóstico do conjunto:

Estado de conservação:

Em funcionamento: Sim [ ] Não [x]

Desativado mas operacional: Sim [ ] Não [x]

BOM [ ] REGULAR [x ] RUIM [ ]

Elementos incorporados: Escada e corrimão externos

Tratamentos efetuados e datas: Em 2007, Foi completamente lacrado para evitar invasões.

Medida de proteção que deve ser tomada: Desassoreamento ( ) limpeza da vegetação ( ) Maior fiscalização (x ) Restauro ( )

Detalhamento:
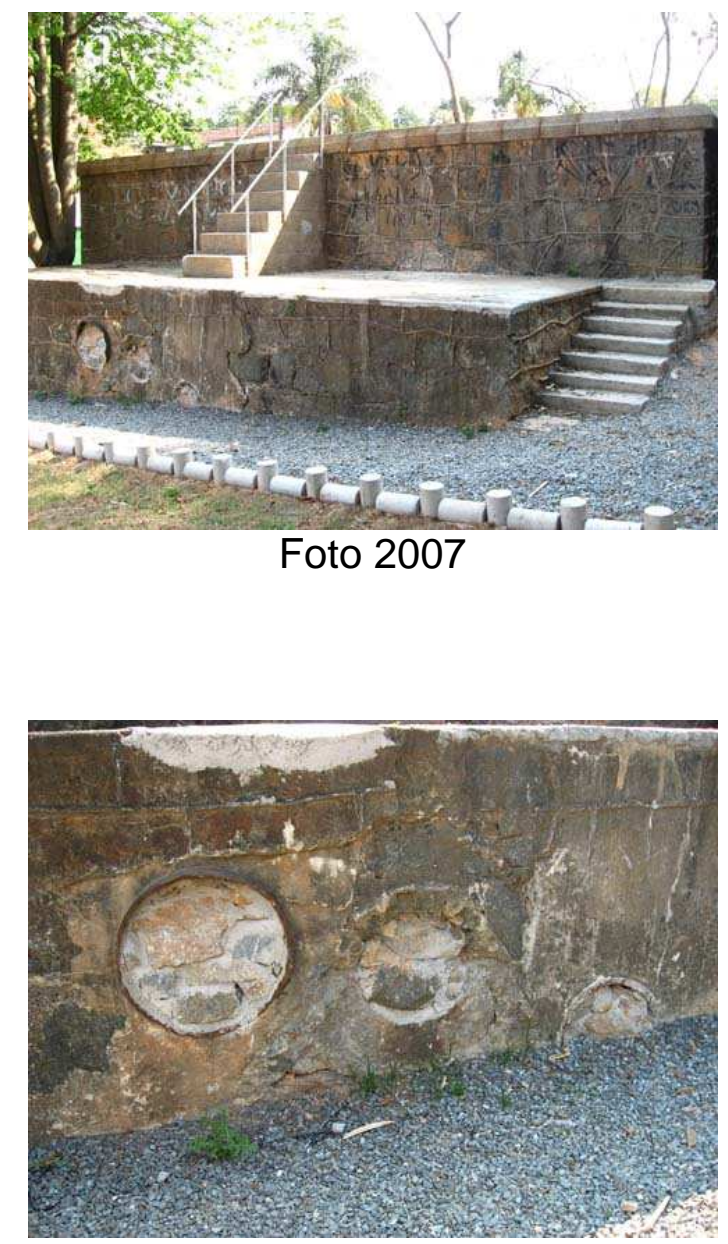

Encanamentos - Foto 2007

$\mathrm{Na}$ parede é possível verificar, que os dutos foram cortados, da esquerda para a direita, o encanamento de ferro de $600 \mathrm{~mm}$, com espessura de $20 \mathrm{~mm}$, instalado após a inauguração, em 1908, da Represa do Engordador, que passou a enviar diretamente grande volume de água; no meio, parte do aqueduto de $500 \mathrm{~mm}$ de tijolos, com espessura de $100 \mathrm{~mm}$, que recebia as águas dos mananciais do 
Cassununga e quase aterrada, à direita, a tubulação de concreto com $450 \mathrm{~mm}$ de diâmetro, e 50mm de espessura, das sobras dos Reservatórios de Acumulação.

\section{Documentação de referência/localização do acervo}

\section{Bibliografia:}

- Relatórios da Repartição de Águas e Esgotos e da Secretaria da Agricultura anos 1893, 1894 e 1895.

\section{Iconografia:}

- Álbum fotográfico P. Doumet de 1893 - Acervo Arquivo do Estado de São Paulo; Fotos P. Doumet de 1894 - Acervo Particular

\section{Observações:}

A Caixa do Guapira e os Reservatórios de Acumulação exigem das autoridades medida urgente de tombamento pelos órgãos responsáveis.

Para os equipamentos situados no Parque Estadual da Cantareira são necessárias ações de conservação e restauro, que pressupõem a salvaguarda definitiva das estruturas, mediante a sua classificação no Plano Diretor ou de Manejo, como Zona Histórica e Arqueológica. 


\section{CONSIDERAÇÕES FINAIS}

Segundo Lefebvre, um duplo movimento impõe-se ao tema estudado, desde que existam tempo e historicidade: regressivo, do virtual ao atual, do atual ao passado, e progressivo, do superado e do finito, ao movimento que declara esse fim, que anuncia e faz nascer algo novo. ${ }^{215}$

O uso desse método, possibilitou verificar ao longo da pesquisa, que os vestígios materiais do antigo sistema de abastecimento de água localizados na Serra da Cantareira, vistos na época de sua implantação, como a solução definitiva para a cidade, estava superado na virada do século.

Todavia, no período entre 1882, ano em que as águas da Cantareira chegaram canalizadas à cidade, e as novas obras realizadas pela RAE, em 1894, a sociedade paulistana passou por uma dinâmica de desencontro de temporalidades, o tradicional em confronto com o novo, o antigo insistindo em se fazer presente.

Como exemplo de antigas atividades sociais, podemos salientar, o transporte de operários e materiais para a construção de reservatórios, com tração animal, carros de boi e burros, bem como, a compra de água através de aguadeiros, ou colhida com vasilhas nos chafarizes. A lavagem de roupas e a higiene pessoal, eram ainda feitas nos rios da cidade.

Como já demonstrado, o salto para a modernidade, começa a se esboçar nas mais singelas atividades sociais, agora os materiais e trabalhadores, usam como meio de transporte a ferrovia urbana - 0 tramway da Cantareira. A água que jorra das torneiras, passa a ter um valor econômico, é paga mensalmente, e exige a introdução nas residências de equipamentos hidráulicos, como chuveiros, pias, banheiras e vasos sanitários, com sistema de esgoto, o que transforma hábitos e costumes arraigados no cotidiano dos paulistanos, na busca da cidade eficiente que era o desejo de uma elite.

Contudo, a superação do antigo pelo novo torna-se imensurável, no eixo espaço-temporal, quando verificamos que a cidade de 30.870 habitantes em 1882 , dez anos depois, na época da encampação da Companhia Cantareira, já atingia 120.000 moradores, e na virada do século, chegava a incrível marca de 239.934 almas.

${ }^{215}$ LEFEBRE Henri, A Revolução Urbana. Minas Gerais, Editora UFMG,2004, P. 33. 
Como vimos, e bem enfatiza Braudel, ${ }^{216}$ os grandes equilíbrios econômicos e os circuitos de trocas, fabricavam e transformavam a trama da vida biológica e social. Os comportamentos se integravam ao gosto de uma classe social, que procurava transformar a inovação em hábito.

O poder público, na esteira das transformações econômicas ocorridas no final do século XIX, aos poucos foi racionalizando os usos sociais das novas infraestruturas.

A coexistência, na vida social, de tempos históricos diversos numa mesma época histórica, ficou visível em 1893, com a destruição dos chafarizes do centro da cidade. Essa medida impopular, anunciava a visão capitalista de mercado, e ironicamente não foi feita por uma empresa privada, mas por uma estatal.

As manifestações de insatisfação não eram apenas sintomas de descontentamento, mas talvez uma forma popular de exprimir sua revolta, com essas e outras medidas tomadas sem qualquer consulta aos seus interesses.

A interação às novas formas de tecnologia muitas vezes camufla outras formas de resistência, como foi a alteração clandestina da calibragem dos orifícios das penas, obrigando o governo a substituí-lo por hidrômetros

Conclui-se que nesse momento, várias lógicas se interligam e por vezes se chocam: a da mercadoria, a do Estado, a da organização espacial, a do objeto, e a da vida cotidiana.

"Rejeitando as particularidades, a racionalidade industrial devasta, pura e simplesmente, a natureza e tudo o que é do domínio da naturalidade".

Uma vez que a regra é o desenraizamento generalizado e as separações, um mal-estar geral acompanha a satisfação vinda da ideologia, do consumo, do predomínio do racional. Tudo se torna calculável e previsível, quantificável e determinável. Tudo deve integrar-se numa ordem fortalecida pelas coações. Tudo, salvo um resíduo de desordem e de liberdade, às vezes tolerado, ás vezes perseguido. Trata-se, então, do período no qual a "história" se precipita, pondo a nu as particularidades e entrando em conflito com o quê ou com quem tinha o privilégio."217

${ }^{216}$ BRAUDEL, Fernand, apud PRIORE, Mary Del, História do Cotidiano e da Vida Privada in Domínios da História Ensaios de Teoria e Metodologia. São Paulo, Editora Campus, 1997, p. 266.

${ }^{217}$ LEFEBVRE, Henri. A Revolução Urbana. Minas Gerais, Editora UFMG, 2004.p.44. 
Com relação à pesquisa tecnológica ${ }^{218}$, Milton Vargas ${ }^{219}$, afirma que seu início se deu efetivamente com três instituições, no século XIX: o Serviço Geológico e Mineralógico do Brasil, no Rio de Janeiro, o Gabinete de Resistência de Materiais da Escola Politécnica de São Paulo ${ }^{220} \mathrm{e}$ o Instituto Agronômico de Campinas. Porém, o autor assegura que é possível que tenha acontecido em outros locais, onde "a nosso ver, isso só se dá efetivamente quando se alia a experimentação de laboratório e de campo, feitas em consonância com métodos de pesquisa científicos, com a necessidade de resolver um problema técnico". ${ }^{221}$ (VARGAS, 1994)

O conhecimento e aplicação de novos materiais, estiveram diretamente ligados com os laboratórios de investigação química e mecânica, onde se estudava e melhorava a composição desses materiais, e se testava a sua resistência.

Como já foi demonstrado, conclui-se que os engenheiros responsáveis pelo saneamento da cidade, realizavam testes de resistência nos materiais importados, no porto de Santos, antes mesmo que esses ensaios fossem sistematizados em disciplina acadêmica específica. Para tanto, José P. S. Pereira de Sampaio, enquanto dirigiu a Comissão de Saneamento do Estado de São Paulo, procurou dotar seu laboratório, dos meios necessários para responder às solicitações de que o departamento era alvo, e prosseguir nas investigações dos novos materiais.

Essa assertiva pode ser comprovada, conforme as afirmações do Relatório Anual de 1894:

"As amostras de cimento oferecido, de várias procedências, têm continuado a ser submettidas a experiências de tracção, na machina "Adie", de que dispomos por enquanto. Chegou-se à conclusão de que os resultados obtidos aqui são sempre inferiores aos que accusam os attestados, que acompanham o material apresentado;

\footnotetext{
${ }^{218}$ Segundo o autor, tecnologia se entenda: o estudo ou tratado das aplicações de métodos, teorias, experiências e conclusões das ciências ao conhecimento dos materiais e processos utilizados pela técnica. A função da engenharia, da arquitetura, da indústria e da agronomia não se confunde com a da tecnologia, embora existia uma tecnologia implícita nessas profissões, pois nelas aparece, também, a arte de construir obras, fabricar produtos ou cultivar a natureza pra obter produtos específicos. Enfim, a visão tecnológica é ampla e não visa a nada de especificamente particular, enquando a do engenheiro industrial ou agrônomo visa particularmente a uma determinada obra ou produto. Ibidem p. 213.

${ }^{219}$ VARGAS, Milton.Organ. O início da pesquisa tecnológica no Brasil. In História da Técnica e da Tecnologia no Brasil. São Paulo, Editora UNESP, 1994, p. 214.

${ }^{220}$ Segundo NAGAMINI, A criação da Escola Politécnica de São Paulo em 1893, e outros cursos de engenharia no país, está relacionada com a necessidade de modernizar os sistemas de transportes e instalar novos serviços de utilidade pública, como eletricidade e redes de abastecimento de água e de tratamento de esgotos. NAGAMINI, Marilda, 1889 - 1930: Ciência e Tecnlogia nos processos de urbanização e industrialização. In MOTOYAMA, SHOZO (Org). Prelúdio para uma História Ciência e Tecnologia no Brasil.São Paulo, Edusp, 2004, p. 196.

${ }^{221}$ VARGAS, Milton. Obra cit. p. 214.
} 
explicação cabal do facto póde-se encontrar na circunstância de achar-se o cimento sensivelmente hydratado, quando nos chega aqui, depois de longa viagem por mar e de longo depósito em logares pouco apropriados.

Melhores e mais positivos resultados iremos, por certo, colher das experiências que hão de ser feitas pela máquina da casa $\mathrm{H}$. Morin, que se acha encomendada e que é dos aparelhos mais perfeitos para experiências desse gênero."222

“(...) Com a machina Adie tem sido feito algumas experiencias de cimento e outros materiais, experiências que devem prosseguir porque são dados de grande valia para conhecimento perfeito dos materiaes que são offerecidos para os serviços a cargo desta commissão e de qualquer outra."223

Conforme já citado, além do cimento, outros materiais como tijolos e ferro, passaram pelos testes de resistência, podendo-se inferir que tal medida de precaução, foi fundamental para garantir a segurança das obras, gerando o desenvolvimento de novas técnicas construtivas, relativas aos equipamentos coletivos, como pontes no caminho do tramway, aquedutos, represas, e os reservatórios da Consolação e da Liberdade.

"Vencidas as difficuldades que se tem encontrado para obtenção de bom tijolo devido principalmente as más condições da industria nacional, o supprimento ao mercado importará em relevante serviço prestado pela Commissão em benefício particular para as obras de Saneamento, e geral para todas as construcções nesta Capital." 224

Segundo DAUMAS ${ }^{225}$, os engenheiros foram os primeiros a estudar as alterações que os novos materiais produziam nas construções, e tentaram definir a relação entre técnica construtiva, e estética arquitetônica, dando origem a uma "arquitetura de engenheiros", em grande parte associada à arquitetura industrial.

Entretanto, PICON, generaliza ao afirmar: "A apologia da funcionalidade da construção, da sua adequação aos fins a que se destinavam remeteu a

\footnotetext{
${ }^{222}$ SÃO PAULO. Relatório annual apresentado ao Exmo Snr Dr Jorge Tibiriça M. D. Secretário da Agricultura pelo engenheiro chefe João Pereira Ferraz, 1894, pp 6, 7.

${ }^{223}$ SÃO PAULO. Relatório Annual da Commissão de Saneamento do Estado de São Paulo apresentado ao Sr Jorge Tibiriça, Secretario da Agricultura pelo Engenheiro Chefe João Pereira Ferraz referente ao anno de 1893, Typographia à vapor de Vanorden e Comp, 1894, p. 07.

${ }^{224}$ SÃO PAULO. Relatório Annual da Commissão de Saneamento do Estado de São Paulo apresentado ao Sr Jorge Tibiriça, Secretario da Agricultura pelo Engenheiro Chefe João Pereira Ferraz referente ao anno de 1893, Typographia à vapor de Vanorden e Comp, 1894, p. 06.

${ }^{225}$ DAUMAS, Maurice. L"Archéologie Industrielle en France. Paris, ed Robert Laffont, 1980, p. 32.
} 
ornamentação arquitetural para um lugar secundário, chegando mesmo a ser considerada por muitos como supérflua."226

No entanto, quando se analisou os aquedutos, as represas e os reservatórios, ficou evidente que esses conceitos não são válidos para a realidade paulistana, uma vez que os profissionais envolvidos, estavam também preocupados com a questão estética.

No caso dos aquedutos, no trecho entre a Cuca e o Bispo, os arcos foram artisticamente trabalhados, e até os encanamentos de ferro do Cassununga, utilizados como colunas, e que servem de suporte à tubulação, estão associados a outros materiais, de forma a obter-se um efeito decorativo, que se estendia às fachadas das edificações, como foi o caso do Reservatório da Liberdade, onde em seu entorno foram incluídas várias figuras mitológicas.

Nesse reservatório, a preocupação estética predominou sobre a da funcionalidade, os engenheiros, procurando dar maior monumentalidade, construíram dois torreões com traçados medievais, e os empreiteiros por conta própria, agregaram um jardim, chamando a atenção para a importância crescente do lazer, e do usufruto do espaço público.

Situada em área urbana, esta edificação talvez, seja a mais emblemática de um imaginário de eficiência, funcionando como uma forma de simbolizar o progresso econômico paulistano, ostentando em sua fachada a frase "Pro S. Paulo Fiat Eximium", para S. Paulo, faça perfeito.

Pelo exposto, para a Arqueologia Industrial, a documentação escrita e iconográfica não deve ser vista apenas como instrumento de consulta e sim como um conjunto que faz parte da memória da empresa, ou seja, como testemunho material e parte integrante do patrimônio cultural, constituindo-se, muitas vezes, nos únicos vestígios materiais que sobraram de uma indústria, um bem coletivo ou de um processo de produção desaparecido.

Para SMITH, "(...) os arquivos representam um produto maior da civilização, uma fonte cultural, um elemento essencial do patrimônio da humanidade."227

\footnotetext{
${ }^{226} \mathrm{PICON}$, Antoine. L"Invention de l'Ingènieur Moderne. L'École des Ponts et Chaussées 1747 - 1851. Paris, Presses de l'École National dês Ponts et Cahusées, 1992, p. 529.

${ }^{227}$ SMITH, W.I. Les archives et la culture. In Techniques modernes d'adiministration des archives et de gestion des documents: recueil de texts. Paris, Unesco, 1985, p 471.
} 
No arquivo público do Estado de São Paulo está conservada a documentação oficial. Como a Companhia Cantareira prestava serviços para o Governo, embora fosse uma entidade privada, parte de sua correspondência foi preservada, principalmente aquela referente aos pedidos de isenção de tarifas de importação, e à cobrança de água e esgotos.

Através da documentação produzida e recebida pela empresa, no decorrer de sua rotina administrativa, a informação dos documentos de arquivo, desvenda a vida do coletivo, facultando o conhecimento que permite determinar os momentos de sua expansão e estagnação, fornecendo elementos que habilitam conhecer as ações que acabaram determinando o seu destino. ${ }^{228}$

Seus arquivos, constituem um universo documental importantíssimo, para o estudo e o conhecimento do nosso passado mais recente, no entanto, são os testemunhos da história da industrialização que primeiro desaparecem, quando uma empresa abre falência ou é encampada, como constatamos, no caso da Companhia Cantareira. Infelizmente, ao longo do tempo desapareceram os livros manuscritos de atas das assembléias, de reuniões de diretoria, do Conselho Fiscal, diários e livros de contabilidade, folhas de pagamento, fichas de operários, assim como as cartas trocadas com representantes de empresas, fornecedores e decisões relativas a investimentos, essencial para a compreensão do seu funcionamento.

Esta lacuna prejudica uma comparação entre a Companhia Cantareira de capital privado, e a Repartição de Águas e Esgotos, pública, uma vez que embora atuassem na mesma área, sua visão administrativa era diferente.

Os agentes econômicos privados, buscam incessantemente a reprodução do capital, ou seja, a constante obtenção de lucros. A diferença fundamental é que uma empresa particular que opera com dificuldades pode ir à falência, ao passo que uma estatal recebe subsídios do governo para manter-se.

Sendo a RAE, uma empresa de serviço público, com monopólio e recursos governamentais, sua margem de competitividade era inexistente, e não havia preocupação com lucro. Esses fatores, talvez, expliquem os vultuosos investimentos e a rapidez da implementação da infra-estrutura no abastecimento de água, a partir de 1893.

\footnotetext{
${ }^{228}$ CORDEIRO, José Lopes. "A investigação em Arqueologia Industrial" in O Porto Manufactureiro e Fabril. Porto: Seção Norte da Ordem dos Engenheiros, 1986, p. 15. (dat)
} 
Para reconstituir a expansão implementada pela RAE, a técnica empregada e o processo de trabalho utilizado, além da pesquisa de campo, efetuada, também foram fundamentais, em nosso estudo, a consulta aos relatórios e as fotografias da época.

Nos projetos de 1864, 1875 e 1877, constatamos a necessidade de se trazer engenheiros ingleses, devido à falta de formação superior técnica ligada à necessidade de domínio tecnológico específico, porém, dessa data em diante, seria cada vez maior a participação brasileira nos estudos e nas construções.

Em 1893, quando a Superintendência de Obras, e posteriormente, a R.A.E., assumiram os serviços de abastecimento de águas e esgotos, que eram chefiados por José Pereira Rebouças, contavam com equipes de engenheiros brasileiros formados principalmente no Rio de Janeiro.

Verificou-se que a importância dessas atividades no contexto urbano, com a diversificação de frentes de ação, a abertura de estradas de ferro, construção de pontes e edifícios públicos, fez com que fosse estruturado um curso de engenharia em São Paulo, a Escola Politécnica.

Quando foi realizada a pesquisa de campo não se confirmou, pelo menos nas obras realizadas entre 1893 e 1894, a presença de material hidráulico de fabricação nacional. Ou seja, desde o início das obras em 1877, pela Companhia Cantareira, até a Repartição de Águas e Esgotos, em 1893/4, o Estado continuava dependente das importações.

Observou-se que no trecho compreendido entre a represa da Cuca e a do Cassununga, os encanamentos foram fabricados pela empresa Hopkins, Causer \& Hopkins, que mantinham seus representantes em São Paulo, conforme fotos apresentadas no capítulo, Convergindo para a Arqueologia da Serra da Cantareira. Esta informação foi ratificada pela documentação escrita.

Porém, no caso específico das primeiras represas do Engordador, não foi encontrado material desta empresa, e sim da CieGle Liege, provavelmente de origem belga, que não foi mencionada em nenhum relatório da RAE, ou da Secretaria da Agricultura. Nesse caso, a fonte escrita, principal auxiliar da Arqueologia Industrial, não confirma o que foi encontrado na pesquisa arqueológica de campo. 
Todos os equipamentos hidráulicos eram importados, e, ao contrário de nossa premissa, de que o material empregado nas obras de abastecimento de água, seria aos poucos substituído por similar de fabricação nacional, isso não se confirmou.

Com relação aos outros serviços de saneamento, houve um incentivo às empresas paulistanas, os empreiteiros eram brasileiros, assim como a Companhia Mechanica e Importadora, que vendia materiais trazidos principalmente da Inglaterra, e que fabricou os dois portões de ferro batido do Reservatório da Liberdade, a armação especial de metal da ponte sobre o Tamanduateí, e parte da estrutura da ponte sobre o Rio Tietê.

Embora os relatórios da Secretaria da Agricultura, mencionem que no Cassununga foram usados tubos da empresa alemã Mannesman, isto não foi comprovado, no trabalho de campo, o material empregado é da Hopkins, Causer \& Hopkins, o mesmo fabricante das outras obras de captação na Serra da Cantareira.

Essas obras não reduziram as importações; ao contrário, provocaram aumento considerável na demanda por artigos estrangeiros, usados nessas construções.

A implementação da infra-estrutura de abastecimento de água no final do século XIX, beneficiou o estabelecimento de representantes de empresas inglesas, comum em regiões de capitalismo tardio como era o caso paulistano.

A subordinação tecnológica fica evidente nos vestígios encontrados e, mesmo o material que em campo é difícil apurar a procedência, como é o caso do cimento empregado, de acordo com a documentação escrita, também era importado. Nas obras emergenciais como a do Cassununga e do Reservatório de Acumulação, o cimento vinha de várias regiões da Europa, em navios de bandeira alemã. Porém, a partir de 1894, com a ampliação dos serviços, os folhetos de propaganda e as notas fiscais apontam novamente para a dependência inglesa.

Em função do rigor dos técnicos da Comissão de Saneamento e da Superintendência, na aquisição dos materiais, junto aos pedidos de licitação, eram anexados, prospectos, cartas de referência e panfletos dos fabricantes.

Os Catálogos daquele período, se constituem em patrimônio documental importante, para o resgate das técnicas de manufatura de alguns artigos. De acordo 
com Pannel, ${ }^{229}$ este tipo de registro impresso é difícil de ser encontrado, quando se trata de empresa européia, devido aos dois conflitos mundiais, e ao fato de ser até há pouco tempo, negligenciada em prol de uma literatura considerada mais técnica.

Para o arqueólogo industrial, sua consulta é indispensável, uma vez que ao comprovar as qualidades de seu produto, as empresas procuravam detalhar 0 processo de fabricação, como se pode ver nas ilustrações do catálogo de $1894^{230}$.

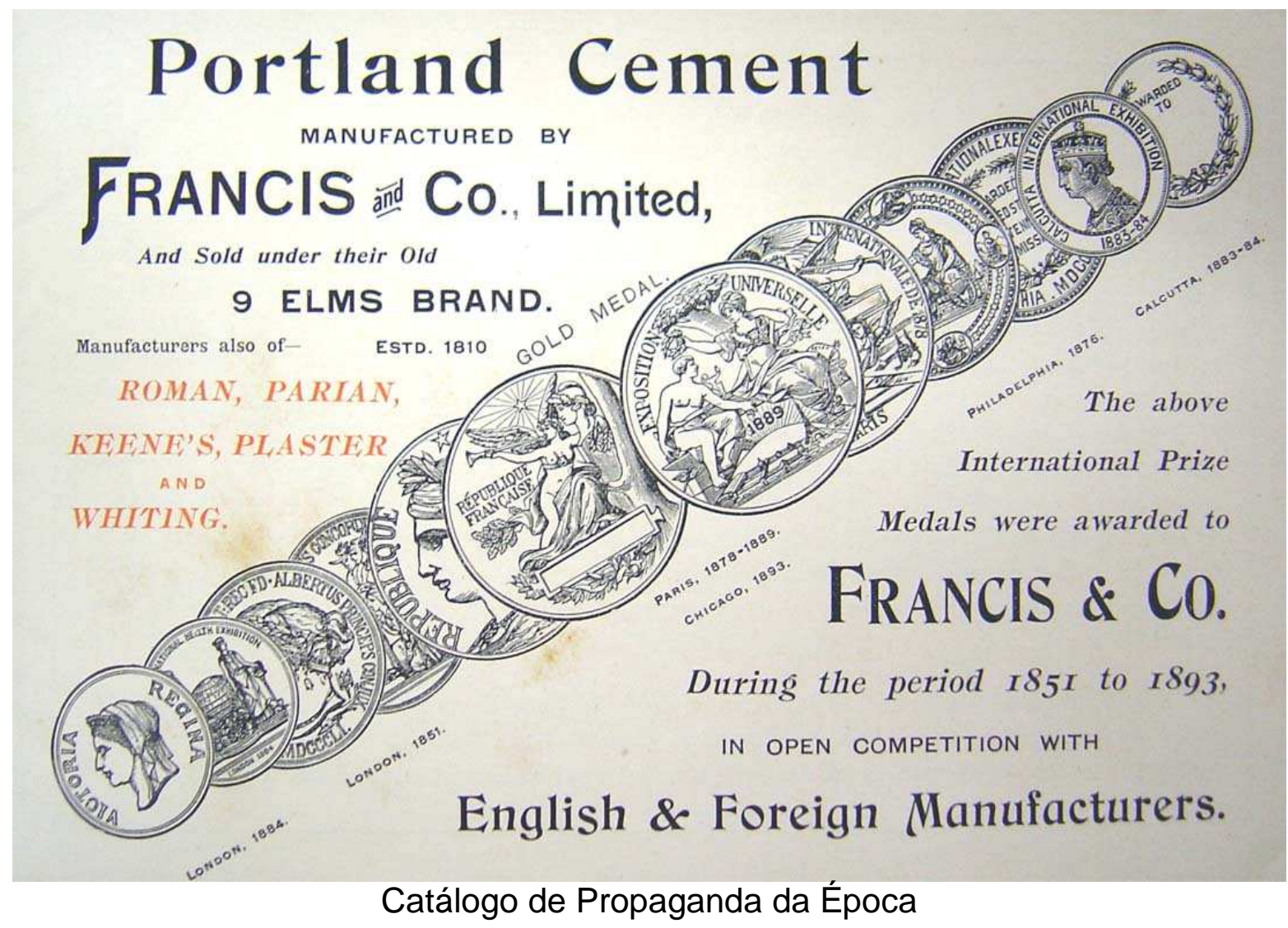

${ }^{229}$ PANNEL; J.P.M. The Techniques of Industrial Archaeology, Great Britain, edited by J. Kenneth Major, 1984.

${ }^{230}$ Catálogo da Francis \& Co. Portlant Cement Acervo Arquivo do Estado, 1894, Secretaria da Agricultura, Cx 118, ordem CO 4212. 

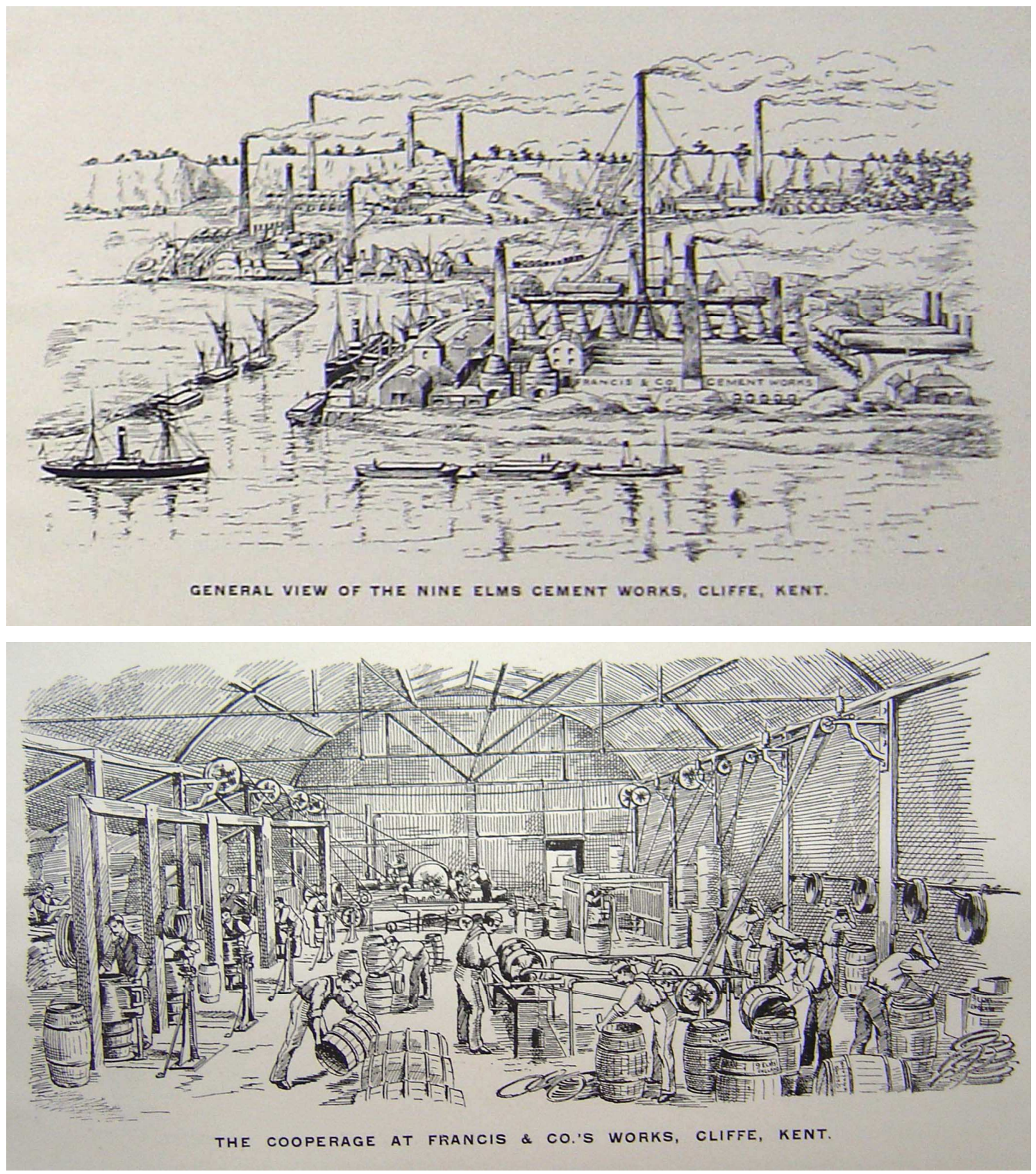

llustrações do catálogo 

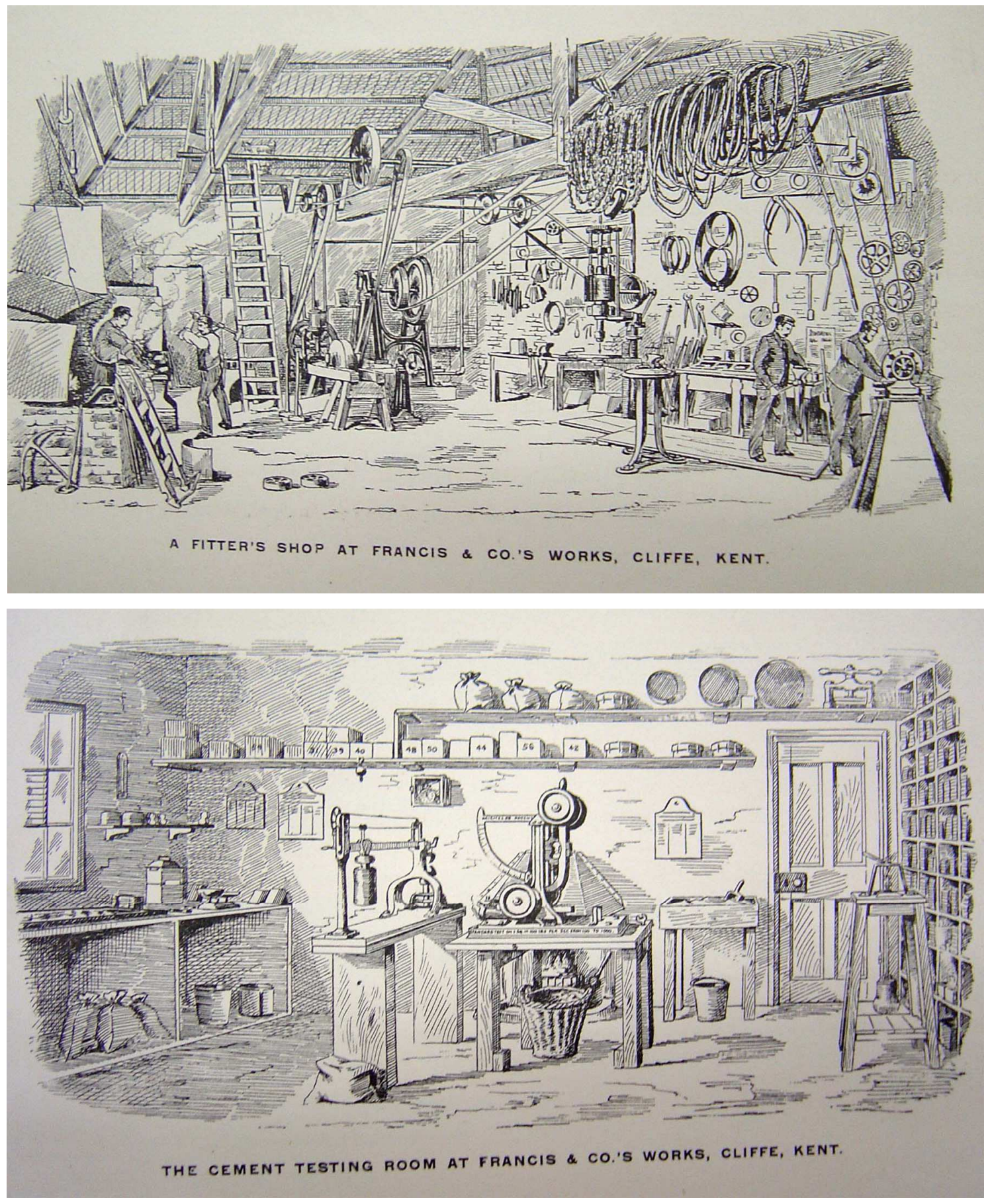

Ilustrações do catálogo

Adquirido através de representantes autorizados, o valor era pago à vista em libras esterlinas, todo o material vinha em embarcação estrangeira, chegava ao Porto de Santos e era transportado pela estrada de ferro da São Paulo Railway até o Pari, seguindo em locomotivas norte-americanas Baldwin ou inglesas, até o Reservatório de Acumulação, de onde em carros de boi, chegavam ao seu destino. 
Naquele momento, a industrialização por meio de substituição de importações, talvez por não exigir o emprego intensivo de capital, ou pela facilidade do acesso à matéria prima, resumia-se aos produtos de olaria ${ }^{231}$ :

No trecho em forma circular foram usados tijolos cuneiformes fabricados pela Companhia Melhoramentos de São Paulo; na secção ovóide além dos especiais fabricados por esta Companhia, tem sido usados tijolos de boa qualidade, com forma e dimensões ordinárias, tendo sido isto preciso para attender a marcha acelerada que imprimiram os empreiteiros aos seus serviços. ${ }^{232}$

No entanto, os dados evidenciam que em relação à fabricação de tijolos o setor ainda estava em processo de estruturação, modesto mas efetivo:

"Quanto aos tijolos devo dizer que foi adoptada para as obras a melhor classe deste material que existia no mercado proximamente igual ao estrangeiro de melhor fabrico e incontestavelmente superior ao material geralmente empregado nesta Capital. São taes tijolos fornecidos, mediante contracto, por Corbett \& Cia actuaes proprietarios da antiga fabrica Ceramica situada no Ypiranga. A resistencia desse tijolo é de cerca de 90 kilogrammas por centimetro quadrado e a capacidade de absorpção varia pelas experiencias feitas, entre $11 \%$ e $18 \%$ de peso.

Vencidas as difficuldades que se tem encontrado para obtenção de bons tijolos devidas principalmente as más condições da industria nacional, o supprimento ao mercado importará em relevante serviço prestado pela Commissão em benefício particular para as obras de Saneamento, e geral para todas as construcções nesta Capital." ${ }^{\text {"33 }}$

Constata-se que, parte da infra-estrutura do sistema de abastecimento de água do final do século XIX, foi destruída, encontrando-se em ruínas, no entanto, está praticamente preservada aquelas que se encontram no perímetro do Parque Estadual da Cantareira, o que não ocorreu com o sistema de distribuição, situado na área urbana, com duas exceções: a Caixa da Consolação, e a da Liberdade que ainda estão em uso.

\footnotetext{
${ }^{231}$ Outro fator que pode explicar essa participação é a tradição deste setor na cidade. Pode-se encontrar em dados estatísticos na obra de Daniel Pedro Muller que a fabricação de telhas, 80.000 unidades, aparece como a principal produção do Município de São Paulo em 1836. MÜLLER Daniel Pedro. Ensaio d'um quadro estatístico da Província de São Paulo. 3 ed. Facsimilada. São Paulo. Imprensa Oficial, 1978, p. XXIII.

${ }^{232}$ RIO DE JANEIRO. Relatório apresentado ao Presidente do Estado de São Paulo pelo Secretário de Estado dos Negócios da Agricultura, Commercio e Obras Publicas, em 4 de abril de 183, Rio de Janeiro, Typ. G. Leuzinger e Filhos, 1893, p. 86.

${ }^{233}$ SÃO PAULO. Relatório Annual da Commissão de Saneamento do Estado de São Paulo apresentado ao Sr Jorge Tibiriça, Secretario da Agricultura pelo Engenheiro Chefe João Pereira Ferraz referente ao anno de 1893, São Paulo, Typographia à vapor de Vanorden e Comp, 1894, p. 05.
} 
No entanto, observou-se que as represas localizadas nas divisas do Parque, sofrem constantemente com as depredações, pois estão em local de fácil acesso aos moradores do entorno, o que dificulta a fiscalização por parte da administração do Próprio Estadual.

Com relação aos aquedutos, no trecho entre a Cuca e o Bispo, o problema de se registrar sua exata localização reside, como já foi visto, no fato de existirem poucas fontes de consulta, o que seria resolvido,com trabalho de campo, caso o pesquisador pudesse acompanhar toda sua extensão, situada na linha divisória do parque, porém o que inviabiliza o procedimento é a constante ameaça de invasores que ocupam indevidamente, o entorno da Unidade de Conservação.

No final do século XIX, acreditava-se que a captação de águas, naturalmente puras, para o abastecimento das cidades, seriam aquelas das nascentes e cabeceiras dos rios localizadas fora dos centros habitacionais.

Para que isso fosse possível, seria fundamental a manutenção de florestas no entorno dos mananciais, sem a presença humana na bacia hidrográfica.

O próprio Código Sanitário Decreto 233/1894 determinava em seu artigo Capítulo 15, sobre o abastecimento de água:

“Artigo 311: a água destinada aos usos domésticos deverá ser potável e inteiramente suspeita de poluição.

Artigo 312. provirá de manancial sempre que for possível com origem na serra.

Artigo 324: para o suprimento à população deverá ser preferido o sistema de condução de água por gravidade."234

Quando encampou a Companhia Cantareira o Governo do Estado adquiriu todo o seu patrimônio que incluía o Reservatório de Acumulação. Logo os técnicos da Superintendência, concluíram, que seria necessário a desapropriação de grande extensão de terras, se quisessem ampliar a captação das águas na Serra da Cantareira.

Foi aberto um crédito especial, e o Estado passou a comprar todas as propriedades particulares, situadas nas proximidades dos mananciais protegendo essas águas superficiais:

\footnotetext{
${ }^{234}$ SÃO PAULO. Coleção de Leis e Decretos do Estado de, Decreto 233 de 02 de Março de 1894. Institui o Código Sanitário do Estado e dá outras providências, 1895.
} 
Esses terrenos desapropriados pelo Estado, e outros adquiridos ao longo do século XX, formam a área do Parque Estadual da Cantareira.

A partir de 1911, a Repartição de Águas e Esgotos contou com o apoio do então Serviço Florestal na vigilância e preservação das matas.

Conforme as represas foram sendo desativadas, a administração da área foi sendo transferida para o Instituto Florestal, culminando em 1963 com a criação do Parque Estadual da Cantareira.

As florestas em virtude de sua função protetora de mananciais, da topografia e declividade do solo, são consideradas de Preservação Permanente de acordo com o artigo $2^{\circ}$ do Código Florestal brasileiro. ${ }^{235}$

Com a Resolução 18 de 04 de Agosto de 1983 o Secretário da Cultura tombou a área do Parque e definiu em seu Artigo 3o:

" $01 \ldots$

02. As instalações públicas preexistentes na área, como torres de alta tensão, atalhos, trilhas, estradas, reservatórios, equipamentos, edificações, ${ }^{236}$ etc, serão mantidas na íntegra com suas funções originais..."237

Um Parque Estadual é uma área de domínio público, destinada à conservação e preservação dos seus ecossistemas.

Segundo o Decreto o 25.341 de 04 de Junho de 1986 que aprova 0 Regulamento dos Parques Estaduais Paulistas, a fim de compatibilizar a preservação desses ecossistemas protegidos, com a utilização dos benefícios deles advindos, serão elaborados estudos de diretrizes, visando a um manejo ecológico adequado, e que constituirão o Plano de Manejo.

No caso específico da Cantareira, quase uma década antes desse diploma legal, a equipe do Instituto Florestal já havia elaborado um Plano de Manejo para o parque.

Nele, as represas do século XIX estão inseridas na Zona de Uso Extensivo, que visa:

\footnotetext{
${ }^{235}$ SÃO PAULO. Leis, Decretos. Lei o 4.771, de 15 de Setembro de 1965, Institui o Código Florestal Brasileiro e dá outras providências. ${ }^{236}$ Grifo nosso.

${ }^{237}$ SÃO PAULO. Leis, Decretos, Resolução 18 de 04 de Agosto de 1983 Fica tombada a área da reserva estadual da Cantareira e Parque Estadual da Capital (Horto Florestal)
} 
Manter o ambiente natural, mas proporcionar melhorias para facilitar o uso recreativo disperso e educação sobre o meio ambiente, tais como: estradas secundárias, atalhos (picadas), sinais indicativos e pequenos grupos de melhoras rústicas espalhadas, incluindo sanitários. ${ }^{238}$ (NEGREIROS, 1974)

Observarmos que a herança do abastecimento de água e sua importância histórica, eram completamente ignoradas: " as represas, as caixas de captação, pequenos lagos e córregos que percorrem ou se encontram nas áreas, não se prestam muito à pesca esportiva, visto contar com espécies introduzidas de pouco valor (tilápias, carpas e blackbass) e outros nativos de valor ainda menor, como traíras, pequenos bagres, lambarís e guarus..."239

O Manejo está desatualizado, com as novas diretrizes de gerenciamento de uma Unidade de Conservação, visto que o Decreto 25.341/1986 define como Zona Extensiva. "Aquela constituída em sua maior parte por áreas naturais, podendo apresentar alguma alteração humana..."240

O que se pode deduzir, e que mostra a falta de conscientização da opinião pública, e dos poderes constituídos, é que, três décadas depois da elaboração do Plano de Manejo do Parque Estadual da Cantareira, esta visão ainda persiste. A área sob a responsabilidade da sucessora da antiga Repartição de Águas e Esgotos, se encontra fora do Parque, e é administrada como se fosse propriedade particular da Associação dos Funcionários da Superintendência de Abastecimento Público do Estado de São Paulo, SABESP, não permitindo o acesso aos pesquisadores.

Neste local, histórico e arqueológico, onde está localizado o primeiro Reservatório de Acumulação, da cidade de São Paulo, assim como as represas do Guatemy, Toucinho, e Barro Branco, virou um ..."Pesque e Pague".

As obras situadas na Serra da Cantareira, constituem um conjunto importante que testemunha a evolução da infra-estrutura do abastecimento de água. A percepção da importância dessas instalações, permitirá a sua preservação e a transmissão desse patrimônio para as gerações futuras, permitindo a comparação com as novas tecnologias, que estão permanentemente em evolução.

\footnotetext{
${ }^{238}$ NEGREIROS, O.C. et elli Plano de Manejo para o Parque Estadual da Cantareira. Boletim Técnico do Instituto Florestal no 10, São Paulo, 1974,p.19.

${ }^{239}$ Ibidem p.11.

240 SÃO PAULO. Leis, Decretos etc. Decreto o 25.341, de 04 de Junho de 1986: Aprova o Regulamento dos Parques Estaduais Paulistas.
} 
Acreditamos que esta pesquisa arqueológica industrial, com seu respectivo inventário, fornecerá subsídios para a proposta de um novo zoneamento para o Parque Estadual da Cantareira, incluindo todo o conjunto de captação de água em uma área de visitação pública, denominada Zona Histórico - Cultural, prevista no Decreto 25.341/1986, como "aquela onde são encontradas manifestações históricas e culturais ou arqueológicas, que serão preservadas, estudadas e interpretadas para o público, servindo à pesquisa, educação e uso científico. O objetivo geral do manejo é o de proteger sítios históricos ou arqueológicos em harmonia com o meio ambiente". 


\section{BIBLIOGRAFIA CITADA}

AGUIRRA, João B. C. Vida Orçamentária de São Paulo, durante um século. In Revista do Arquivo Municipal, São Paulo, vol II,1934.

BARBIERI, Franco. "Archologia industriale e storia dell'arte". In Archeologia Industriale. Indagini sul território in Lombardia e Veneto. Edizioni Unicolpli., Milano, 1989.

BARBUY, Heloísa. A Cidade-Exposição - Comércio e Cosmopolitismo em São Paulo, 160 - 1915. São Paulo, EDUSP, 2006.

BARRAL I ALTET, Xavier. L'Archéologie de l'age industriel, Archéologie et Industrie. In: Les Dossiers de L’Archéologie. Dijon: Faton, 1986.

BERNARDINI, Sydney P. O engenheiro Estevan A. Fuertes e seu plano sanitário para Santos (1892 - 1895) in GITAHY (org) Desenhando a Cidade do Século XIX, São Paulo, editora Rima, 2005.

BLOCH, Marc. Caractéres Originaux de L'Histoire Rurale Française.Paris, 1935.

BRAUDEL, Fernand. Civilização Material, Economia e Capitalismo.,São Paulo Ed.Martins Fontes, , 1998

BRAUDEL, Fernand, apud PRIORE, Mary Del, História do Cotidiano e da Vida Privada in Domínios da História Ensaios de Teoria e Metodologia. São Paulo, Editora Campus, 1997.

BRITTO,E. São Paulo Tramway Tremembé, São Paulo,Ed Prancom, , 1999.

BUCHANAN, A. The Definition of Industrial Archaeology, In "L'étude et la Mise en Valeur du Patrimoine Industriel. 4a Confèrence internationale.Lyon-Grenoble, Septembre 1981. Ed.du Centre National de La Recherche Scientifique. Paris, 1985. 
CAMPOS, Eudes. São Paulo: desenvolvimento urbano e arquitetura sob o Império.In História da Cidade de São Paulo: a Cidade na Primeira Metade do Século XX: 18901954. São Paulo Editora Paz e Terra., 2004.

CAMPOS, Nilson et all. Gestão das Águas.Princípios e Práticas. Porto Alegre, Editora da Associação Brasileira de Recursos Hídricos., 2003.

CANO, Wilson. Raízes da concentração industrial em São Paulo, Campinas, UNICAMP, 1998.

CARONE, Edgar. A República Velha (Instituições e Classes Sociais), São Paulo, Difusão Européia do Livro, 1972.

CARONE, Edgard. A Evolução Industrial de São Paulo. 1889 - 1930.São Paulo, Ed Senac. 2000.

Carta de Nizhny Tagil de 2003, sobre o Patrimônio Industrial, elaborada pelo TICCIH (The International Committee for the Conservation of the Industrial Heritage.

CATÁLOGO da francis \& Co. Portlant Cement Acervo Arquivo do Estado, 1894, Secretaria da Agricultura, Cx 118, ordem CO 4212.

CORDEIRO, José Lopes. "A investigação em Arqueologia Industrial' in O Porto Manufactureiro e Fabril. Porto: Seção Norte da Ordem dos Engenheiros, 1986.

.José Manoel Lopes Um serviço centenário: o abastecimento domiciliário de água à cidade do Porto (1887 - 1987) Separata de Arqueologia Industrial II série, Vol. I, № 1/2 1993.

.José Manoel Lopes. Arqueologia Industrial, uma vertente fundamental da Arqueologia Urbana. Encontro de Arqueologia Urbana, Braga, 1994. 
CORREA, Dora, ALVIM, Zuleika. M. F. A água no olhar da História, São Paulo, Secretaria do Meio Ambiente, 1999.

COSTA, Luiz Augusto Maia O ideário urbano paulista na virada do século. São Paulo. Rima Ed. 2003.

CUSTODIO, J. Arqueologia Indústria e Patrimônio in História e Crítica, Lisboa, nํ5, maio de 1980 .

.Jorge. Método Comparativo e Método Regressivo na detecção do Moinho Gigante do Barão do Sobral, erigido no Barreiro. In I Encontro Nacional sobre o Património Industrial. Vol II, Editora Coimbra, Coimbra, 1990.

Correio Paulistano, №2335, de 28 de Fevereiro de 1864.

DAUMAS, Maurice. L"Archéologie Industrielle en France. Paris, ed Robert Laffont, 1980.

. Maurice, apud ANDRIEUX, Jean-Ýves. Que sais-je? Le Patrimoine Industriel. Paris, France, Presses Universitaires de France, , 1992.

DEAN, Warren. A industrialização de São Paulo 1880 - 1945. São Paulo. DIFEL, 1971.

DECLARAÇÃO DO GEHT, em defesa das construções e instalações utilitárias ("Carta de Campinas") - UNICAMP, 1998.

DELAUNAY, C. Aspects of Council of Europe Action,. The Industrial Heritage: What Policies?, Council of Europe, Architectural Heritage and Studies, ํㅜㄹ. Estraburgo, 1987.

DIÁRIO POPULAR - Série de artigos publicados no ano de 1892, com o título de Questões de Actualidade. Saneamento de S. Paulo, Capítulo X, Companhia Cantareira. 
DIÁRIO POPULAR de 12 de março de 1892.

DIÁRIO POPULAR, de 16 de agosto de 1892.

DROR, V. In ANDERSON, C.A. Le contexte social de la planificacion de l'education. Paris, UNESCO, 1968.

ENGELS, Friedrich apud LAKATOS, Eva Maria. Fundamentos de Metodologia Científica, São Paulo, ed Atlas, 1991.

FOLGADO, Deolinda. Instituto Português do Património Arquitectónico: Inventário doPatrimóniolndustrial.InPatrimónioEdificado.Novas Tecnologias.Inventários.Editora do Instituto Açoriano de Cultura. Angra do Heroísmo, 2002.

FREITAS, Affonso A. de. Diccionario Historico, Topographico, Ethnographico Illustrado do Município de São Paulo. Tomo I. SP: Graphica Paulista, 1929.

FRICK, John. Ar Puro. Rio de Janeiro ed Leuzinger, 1889.

FURTADO, Celso. Formação Econômica do Brasil. São Paulo. Cia Ed. Nacional, 2003.

GARCIA, Mercedes Lopez, "La obra Publica, Investigacion y Practica" in I Encontro Nacional sobre o Património Industrial, vol I Coimbra editora Ltda, 1989.

GUERRAND Roger-Henri. Espaços Privados in PERROT, Michelle (org) História da Vida Privada Da Revolução Francesa à Primeira Guerra. São Paulo, Cia das Letras, 1991.

HARDMAN, Francisco F. Trem Fantasma. A modernidade na selva. São Paulo. Companhia das Letras, 1988. 
HENRIQUES, Isabel. A Fábrica da Companhia de Cerâmica de Telheiras. Algumas questões de método. In I Encontro Nacional sobre o Património Industrial. Coimbra Ed.Coimbra, 1990.

HODDER, Ian. InterpretaciónEnArqueología.Corrientes.Acutales,Barcelona,E.Crític. 1994.

HOMEM, Maria Cecília Naclério. O Palacete Paulistano e Outras Formas Urbanas de Morar da Elite Cafeeira. 1867 - 1918. São Paulo. Martins Fontes. 1996.

HUDSON Keneth, Apud KÜHL, B.N. Arquitetura do ferro e Arquitetura Ferroviária em São Paulo: Reflexões sobre a sua preservação. São Paulo, Ed. Ateliê, 1998.

HUDSON, Kenneth.Industrial Archaeology, an Introduction.2 ${ }^{\mathrm{a}}$ ed London..John Baker Publishers.

HUMBER William A Comprehensive Treatise on the Water Supply of Cities and Towns, London, Crosby Lockwood and Co, 1876.

JAUME Valentines Alvarez. Arqueologia Industrial I Ecomuseografia a Les Universitats. El Cãs de L'ETSEIB, In Quaderns d'Història de L'Enginyeria.Vol.VI, Barcelona, 2004.

JONES, William. Dictionary of Industrial Archaeology.2ed.Sutton Publishing. London, U.K., 2006.

JORGE, Clóvis de Athayde. Consolação uma reportagem histórica, Departamento do Patrimônio Histórico. Divisão do Arquivo histórico, São Paulo, Divisão Gráfica Municipal, , s/data.

- Vitor Oliveira. Projectar o Passado. Ensaios sobre Arqueologia e PréHistória Lisboa, Ed. Presença, 1987

DIÁRIO de São Paulo de 15/12/1868, ㄲo 992. 
José Antonio FernándezOrdónez. "Informe sobre la situación de la Arqueología Industrial y el Patrimonio de Obras Públicas en los países europeos del Mediterráneo y propuestas de acciojnes a emprender para su conservación y reutilización" In Mercedes Lopez Garcia. La Obra Publica, Investigacion y Practica. I Encontro Nacional sobre o Património Industrial. Vol.II, Ed. Coimbra, Coimbra, 1990.

KAHTOUNI, Saide. Cidade das águas. São Paulo. Ed Rima. 2004.

KOSSOY, Boris.A fotografia como fonte histórica. Introdução à pesquisa e interpretação das imagens do passado. Coleção Museu e Técnicas, São Paulo, Museu da Indústria, Comércio e Tecnologia de São Paulo, 1980.

- Boris, Luzes e sombras da metrópole: um século de fotografias em São Paulo (1850-1950) in História da Cidade de São Paulo na Primeira Metade do Século XX 1890 -1954.São Paulo, Paz e Terra, 2004.

${ }^{1} \mathrm{KÜHL}$, Beatriz Mugayar. Arquitetura do Ferro e Arquitetura Ferroviária em São Paulo: Reflexões sobre a sua preservação.São Paulo: Ateliê FAPESP, Secretaria da Cultura, São Paulo, 1998.

LANDI, Francisco R. A Evolução histórica das instalações hidráulicas. São Paulo, Boletim Técnico da Escola Politécnica, no 100, 1991.

LES INVENTAIRES DU PATRIMOINE INDUSTRIEL - Industrial Heritage Inventories, Actes des colloques de la Direction du Patrimoine, França, 1986.

L'ÉTUDE ET LA MISE EN VALEUR DU PATRIMOINE INDUSTRIEL 4" Conférence internationale Lyon - Grenoble, 1985.

LE PATRIMOINE INDUSTRIEL au Québec. Éd.Commission des biens cullturels du Québec.Canadá, 1987.

LEFÈBVRE, Henry. De lo Rural a lo Urbano, Barcelona,Ed. Península, 1978.

LEFÉBVRE, Henry. A Revolução Urbana., Belo Horizonte, Editora UFMG., 2004. 
LOTUFO, C. L. Os Primórdios da industrialização no Município de Engenheiro Frontin, RJ, Munda, № 22, Coimbra, Portugal.

MADEIRA,A. APUD Uma vila industrializada: tortozendo, centro produtor de lanifícios, na área da Serra da Estrela, in I Encontro Nacional sobre o Património Industrial, ed Coimbra, Portugal, 1989.

MARQUES, T. O conceito de carta arqueológica a partir da experiência portuguesa, Vipasca, no02, 1993.

MARTINS, J. A. Reservatórios de Acumulação e Barragens" in Técnica de Abastecimento e tratamento de água, São Paulo, CETESB, ,1996.

MATOS, Odilon Nogueira. São Paulo no século XIX in A cidade de São Paulo Estudos de Geografia urbana, São Paulo, Cia Editora Nacional, S/Data.

MENDES, J. Amado: Construção Civil e Patrimônio Industrial. Revista Munda. Editora Tipografia Comercial Coimbra. Coimbra, 1983.

. J. Amado. Inventariação do Património Industrial in Revista Munda no 16 Coimbra, Portugal, 1988.

José M. Amado. Património Industrial: um bem da comunidade ao alcance da escola. In Revista Munda no 16, Ed.GAAC. Coimbra. 1988.

Amado. A Arqueologia Industrial ao serviço da história local.In Revista de Guimarães, № 105, Guimarães, 1995.

MORSE, Richard M. De Comunidade a Metrópole - Biografia de São Paulo. São Paulo, 1954, Comissão do IV Centenário da cidade de São Paulo, 1954.

MOTOYAMA, SHOZO (Org). Prelúdio para uma História Ciência e Tecnologia no Brasil.São Paulo, Edusp, 2004. 
MÜLLER Daniel Pedro. Ensaio d'um quadro estatístico da Província de São Paulo. 3 ed. Facsimilada. São Paulo. Imprensa Oficial, 1978.

MUMFORD, L. A Cidade na História, usas origens, transformações e perspectivas.São Paulo, Editora Martins Fontes, 1998.

NADAI, Elza. Ideologia do Progresso e Ensino Superior. São Paulo. Ed. Loyola, 1987.

NEGREIROS, Osmar C. de et al, Plano de Manejo para o Parque Estadual da Cantareira. São Paulo, Boletim Técnico do Instituto Florestal no 10, 1974.

NOZOE, Nelson. Vida econômica e finanças municipais da Capital paulista na época imperial, in História da Cidade de São Paulo - A cidade no império 1823 - 1889, São Paulo, Paz e Terra, 2004.

ORSER JR., Charles E.Encyclopedia of historical archaeology.Ed.Charles E.Orser J., New York, Routledge, 2002.

PALMER, Marilyn. Industrial archaeology: a thematic or a period discipline? In Antiquity Cambridge, 1990.

PANNELL, J.P.M. The Techniques of Industrial Archaeology. Ed.by J.Kenneth Major.Great Britain., 1974.

PAULA, Eurípides Simões de. A segunda fundação de São Paulo; da pequena cidade à grande metrópole de hoje. São Paulo, Revista de História, ano V, oㅜ 17, 1954.

PERROT, Michelle (org). História da Vida Privada. Da Revolução Francesa à Primeira Guerra. Vol 4, São Paulo, ed Schwarcz, 1991. 
PICON, Antoine. L'Invention de l'Ingènieur Moderne. L'École des Ponts et Chaussées 1747 - 1851. Paris, Presses de l'École National dês Ponts et Cahusées, 1992.

PINARD, Jacques. L'archéologie industrielle. Paris,.Presses, Universitaires de France, 1985.

PINTO, Alfredo Moreira, A Cidade de São Paulo em 1900. Coleção Paulística vol. XIV, São Paulo. Governo do Estado de São Paulo, 1979.

POUPARD, Aîné, La Plomberie au Point de vue de La Salubrité des Maison par S. Stevens Hellyer (Traduit de L'Anglais, Paris, Librairie Génélarle de L'Architecture et des Travaux Publics, 1886.

PRADAYROL, Jacques.Les chemins de Fer Touristiques. Pionniers de L'Archéologie Industrielle en France. In L'Étude et la Mise en valeur du Patrimoine Industriel. 4은 Conférence internationale Lyon, Grenoble, Ed.du Centre National de la Recherche Scientifique, 1985.

QUINTEIRA, A. J. F.Breve comentário sobre o património, Munda ํㅜ 33, Coimbra, Portugal, 1997.

RIBEIRO, Isabel e SANTOS, Luísa. A indústria do papel na perspectiva da Arqueologia Industrial. In I Encontro Nacional sobre o Património Industrial, Coimbra,. Editora Coimbra, 1990

REIS FILHO, N.G. Quadro da Arquitetura no Brasil, Ed Perspectiva, 1970.

SAES, Flávio Azevedo Marques de. As ferrovias de São Paulo, 1870 - 1950: expansão e declínio do transporte ferroviário em São Paulo, Hucitec, 1981.

SAMPAIO, Teodoro. São Paulo no Século XIX e outros ciclos históricos., Petrópolis, Rio de Janeiro Editora Vozes., 1978. 
SÃO PAULO. Relatório geral das obras publicas apresentado pelo Conselho d'Engenheiros, em 20 de março de 1852 em cumprimento ao $\S 3^{\circ}$ o do Art $3^{\circ}$ do Regulamento de 04 de Outubro de 1851. Acervo do Arquivo do Estado, Setor de Manuscritos Obras Publicas, Anos de 1850 a 1855, Caixa 14, Ordem 5151, Doc C14 P3 93 A.

- Relatório referente ao discurso do Sr José Thomaz Nabuco d'Araujo, Presidente da Provincia de São Paulo abrindo a Assembléia Legislativa Provincial no dia $1^{\circ}$ de maio de 1852. Typ.do Governo arrendada or Antonio Louzada Antunes.São Paulo.

Relatório referente ao discurso do Sr José Antonio Saraiva, Presidente da Província, na Assembleia Provincial no dia 15 de fevereiro de 1855.Typographia 2 de Dezembro de Antonio Louzada Antunes, São Paulo.

. Relatório com que o Conselheiro Antonio José Henriques, Presidente da Província abriu a Assembléia Legistiva Provincial no ano de 1861. Tip Imparcial.

- Relatório apresentado a Assembléia Legislativa da Província, na $1^{\text {a }}$ Sessão da 14a ${ }^{a}$ Legislatura pelo Presidente da Província Dr João Jacintho de Mendonça,Typographia Imparcial, 1862.

. Relatório apresentado a Assembleia Legislativa Provincial, na Primeira Sessão da Decima Oitava Legislatura no dia 3 de Fevereiro de 1866, pelo Presidente da Província Dr João da Silva Carrão, Typographia Imparcial, 1866.

- Relatório apresentado a Assembléa Legislativa Provincial, no dia 2 de Fevereiro de 1868 pelo Presidente da mesma Província o Conselheiro Joaquim Saldanha Marinho.Typographia do Ypiranga, 1868.

- Relatório apresentado à Assembléia Legislativa Povincial, pelo Presidente da Província Dr Antonio Candido da Rocha no dia 2 de fevereiro de 1870. Typographia Americana, 1870. 
- Relatório Apresentado à Assembléia Legislativa Provincial, pelo Presidente da Província o Exmo Sr. Dr José Fernandes da Costa Pereira Júnior em 2 de fevereiro de 1872.

- Relatório apresentado à Assembleia Legislativa Provincial, de São Paulo pelo Presidente da Província Sr. Sebastião José Pereira, em 2 de Fevereiro de 1876,Typographia do Diário.

- Relatório apresentado à Assembléia Legislativa Provincial, pelo Presidente da Província Laurindo Abelardo de Brito no dia 05 de fevereiro de 1880. Typ. à vapor do Diário de Santos.

.Relatório apresentado à Assembléia Legislativa Provincial, pelo Presidente da Província Laurindo Abelardo de Brito no dia 13 de janeiro de 1881. Typ. à vapor do Diário de Santos,

- Relatório dirigido à Assembléia Legislativa Provincial, pelo 1ํㅡㄴ VicePresidente da Província Conde de Três Rios e apresentado no acto da instalação da mesma Assembléia pelo $4^{\underline{a}}$ Vice-Presidente $\operatorname{Dr}$ Manoel Marcondes de Moura e Costa, Typgraphia a vapor do Diário de Santos.1882.

. Relatório Annual da Commissão de Saneamento, apresentado ao Sr Jorge Tibiriça, Secretario da Agricultura pelo Engenheiro Chefe João Pereira Ferraz referente ao anno de 1893, Typographia à vapor de Vanorden e Comp, 1894.

. Relatório apresentado à Câmara Municipal pelo Intendente Municipal Cesário Ramalho da Silva em 1893, 1894.

- Relatório da Secretaria dos Negócios da Agricultura, Commercio e Obras Publicas, apresentado em 03 de Março de 1895 ao Dr Bernardino de Campos, Presidente do Estado pelo Dr Jorge Tibiriça,Typ Paulista, 1895.

Relatório correspondente ao ano de 1899, apresentado ao Presidente do Estado Coronel Fernando Prestes de Albuquerque pelo Alfredo Guedes Secretário da Agricultura,Typographia do Diário Official, 1900. 
. Actos do Poder Legislativo do Estado, Typ. do Diário Oficial, 1892.

., LEIS E DECRETOS ETC. Decreto ํㅜ 58 de 02 de maio de 1892

Regulamenta a Secretaria da Agricultura, Comércio e Obras Públicas e dá outras providências.

. Leis e Decretos. Decreto no 233 de 2 de Março de 1894. O Presidente do Estado, para a execução do artigo 3ำ da Lei no 240 de 4 de Setembro de 1893, estabelece o Código Sanitário.

. Leis, Decretos, Decreto no 152-A de 31 de janeiro de 1893 Cria as Repartições dos serviços de águas e exgottos e da arrecadação das taxas de água da capital.

. Leis, Decretos, Decreto no 154 de 08 de Fevereiro de 1893. Cria e organiza a repartição dos serviços technicos de águas e exgottos da capital

. Colecção de Leis da Assembléia Legislativa Provincial do ano de 1859, Typografia Dous de Dezembro de Antonio Louzada Antunes, 1859.

. Collecção de leis da Assembléia Legislativa Provincial promulgadas no ano de 1866 e dos regulamentos expedidos para execução das mesmas. Typ. Imparcial de Azevedo Marques, 1866.

.Collecção de Leis e Posturas Municipaes promulgadas pela Assembléia Legislativa Provincial, Typographia Americana, 1871

.Leis e Decretos, Lei ํo 13 de 27 de março de 1886. Dispõe sobre habitações populares e dá outras providências.

.Leis e Decretos. Decreto no 41.626 de 30 de janeiro de 1963. Regulamenta a execução da Lei oㅜ 6884 de 29 de agosto de 1961, que dispõe sobre os Parques, Florestas e Monumentos naturais. 
.Leis e Decretos. Decreto n 233 de 2 de Março de 1894. O Presidente do Estado, para a execução do artigo 3ํㅡㄹ Lei no 240 de 4 de Setembro de 1893, estabelece o Código Sanitário.

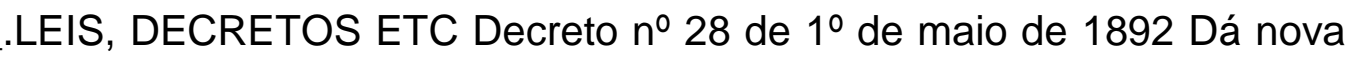
organização a Secretaria da Agricultura, Comércio de Obras Públicas.

.Leis, Decretos. Decreto no 195 de 18 de agosto de 1893. Declara de utilidade publica, para desapropriação, os terrenos do sítio Campo Redondo, na Serra da Cantareira, pertencentes a Antonio Rodrigues de Almeida, Companhia Territorial e Estanislau José de Oliveira Queiroz, precisos para as obras de desenvolvimento do abastecimento de água à capital.

.Leis, Decretos. Decreto no 214 de 04 de novembro de 1893. Declara de utilidade pública, para serem desapropriados pelo Estado, necessários para o aumento dos mananciais do abastecimento da capital, as águas dos córregos das Sobras, Marmeleiro ou Pedra Branca, Tanque, Guarahú, Bispo, Matheus, Itaguassú e Manino, situados à esquerda dos reservatórios de accumulação, na serra da Cantareira.

SCHUMPETER, J.A. Capitalismo, Socialismo e Democracia. Rio de Janeiro, Ed. Fundo de Cultura., 1961.

SILVA, Armando Jorge. Fotografia, Arqueologia e Património Industriais, in I Encontro sobre Património Industrial, vol I, Coimbra Editora, Coimbra, 1989.

SILVA, Francisco Carlos Teixeira da. História das Paisagens, in domínios da História - Ensaios de Teoria e Metodologia CARDOSO,Ciro Flamarion org.São Paulo, Editora Campus, 1997.

SIMÕES JÚNIOR, José Geraldo, o Setor de Obras Pública e as origens do urbanismo na Cidade de São Paulo. Tese apresentada como requisito para a obtenção do título de mestre em Administração Pública pela Escola de Administração de Empresas de São Paulo, Fundação Getúlio Vargas, 1990. 
SIMÕES,R.(org) Equipamentos, usos e costumes da casa brasileira, vol. 3 Costumes, São Paulo, Museu da Casa Brasileira, 2001.

SMITH, W.I. Les archives et la culture. In Techniques modernes d'adiministration des archives et de gestion des documents: recueil de texts. Paris, Unesco, 1985. SOUZA de Sara Regina, Estrada de Ferro "Donna Thereza Christina" in Revista de Arqueologia Industrial vol I n 1-2 Portugal, 1993.

TAUNAY, A. de E. História da Cidade de São Paulo sob o Império. Vol. VI. São Paulo: Secr. Mun. Cultura, 1977

TROTTIER, Rapport (org) Le patrimoine industriel au Québec - État de la Situation et Recommandations Commission des biens culturels du Québec, 1987.

URTEAGA, Luiz. Miseria, miasmas y microbios. Las topografías medicas y el estudio del medio ambiente en el siglo XIX. Barcelona: Revista Geo Critica, no 29, 1980.

VARGAS, Milton. Org. História da Técnica e da Tecnologia no Brasil. São Paulo, Editora UNESP, 1994.

VITERBO, Souza Francisco. "Arqueologia Industrial Portuguesa; os moinhos". In O Arqueólogo Português, Vol II, no 8 e 9, os 68 a 72, 1896. 


\section{BIBLIOGRAFIA CONSULTADA}

ANDRIEUX, Jean-Yves. Le Patrimoine Industriel. Paris, França, Editora Presses Universitaires de France, 1992.

ASSOCIATION FOR INDUSTRIAL ARCHAEOLOGY. Industrial archaeology working for the future. Editora AB Printers limited, Leiscester, Great Britain, 1991.

BLOCH, Marc. Apologia da História ou o ofício de historiador, Rio de Janeiro Editora Jorge Zahar, 1997.

AZEVEdo NETTO, J M. Manual de Hidráulica. São Paulo: USP-FAU, 1954.

BRUNO, E. S. História e tradições da Cidade de São Paulo. III. Rio de Janeiro: José Olímpio, 1954.

BUENO, Laura Machado de Mello, O saneamento na urbanização de São Paulo, Dissertação apresentada à Faculdade de Arquitetura e Urbanism, São Paulo, USP, 1994

CORDEIRO, José Manuel Lopes. O patrimônio industrial da Bacia do Ave e o projecto do Museu da Indústria Têxtil. Museu da Indústria Têxtil, vila Nova de Famalicão, Portugal, 1991.

Museu Têxtil de Terrassa. Museu da Indústria Têxtil de Vila Nova de Famalicão, Portugal, 1991.

. Ecomuseu da região de Fourmies-Trélon, Museu da Indústria Têxtil, Vila Nova de Famalicão, Portugal, 1991.

Museu Hidroeléctrico de Santa Rita.Braga:

Câmara Municipal de Fafe, Portugal, 1991. 
Indústria e Paisagem na Bacia do Ave, Santo

Tirso arqueológico, Santo Tirso II, 1992.

Bibliografia sobre arqueologia, patrimônio e museologia industrial. Arqueologia Industrial, Braga, Portugal, 1993.

A ponte Pênsil (1843-1887), na perspectiva da arqueologia industrial, Gaya, Vila Nova de Gaia, Portugal, 1994.

Patrimônio industrial português. Anais do $1^{\circ}$ seminário nacional de história e energia. Edição do departamento de patrimônio histórico da Electropaulo, São Paulo, 1988.

A indústria conserveira em Matosinhos.

Exposição de arqueologia industrial. Matosinhos, Portugal, 1989.

(org.) Revista de Arqueologia Industrial.

Segunda e terceira séries, nำ 1 e 2, Braga, Portugal, 1993, 1997.

Correio Paulistano, nำ2335, de 28 de Fevereiro de 1864,

Diário de São Paulo de 15/12/1868, no 992.

DIAS,Odila Leite da Silva, Quotidiano e poder em São Paulo no séculoXIX, Editora Brasiliense, São Paulo, 1995.

FOUCAULT, M Microfísica do Poder, Rio de Janeiro, Ed. Graal, , 1990.

FREHSE,Fraya, O tempo das ruas na São Paulo de fins do Império. São Paulo, EDUSP, 2005.

FREITAS, Afonso A. de . Tradições e Reminiscências Paulistanas. 3aㅗ ed. São Paulo: Gov. do Estado, 1978 
FUNDAÇÃO AGBAR. AquaRomana-Técnica humana e força divina. Lisboa, Portugal, Editora Museu Nacional de Arqueologia, , 2005.

JOAQUIM CAETANO. Aquedutos em Portugal. Lisboa, Portugal Editora Heska Portuguesa, S/A,1999.

LEITE, Rogério César de Cerqueira. A agonia da tecnologia nacional., São Paulo, Editora Duas Cidades, 1978.

LEMOS, C.A.C. Casa Paulista História das moradias anteriores ao Ecletismo trazido pelo café, São Paulo, EDUSP, 1999.

O que é Patrimônio Histórico, Editora Brasiliense, São Paulo, 1982

MACEDO, Jorge, Arqueologia Industrial, Enciclopédia Luso-Brasileira de Cultura, 21ํㅡㄹ vol,Portugal, Ed Verbo, 1986.

MARTINS, Antonio Egydio. E. São Paulo Antigo. 2ํㅡ. Vol. São Paulo: Tip. Diário Oficial, 1912.

MORSE, R. M. Formação Histórica de São Paulo. São Paulo: Difusão Européia do Livro, 1970.

MOURA, Carlos Eugenio Marcondes de (Org.). Vida Cotidiana em São Paulo no Século XIX. São Paulo: UNESP / Impr. Oficial do estado, , 1998.

OLIVEIRA, et all, Técnica de abastecimento e tratamento de água, Volume I, São Paulo, CETESB, 1987

RENFREW, Colin. e BAHN, Paul. Arqueología Teorias, Métodos y Práctica. Madrid, Espanha, Editora. Akal S/A 1993. 
RIBEIRO, M.A.R. História sem fim...Inventário da Saúde Pública São Paulo - 1880 1930, Ed UNESP, 1993.

SIMÕES JUNIOR, J.G. Anhangabaú: história e urbanismo. Monografia de doutorado. São Paulo: USP, 1995.

SOUTO L.R.V. Hygiene da habitação - Casas para operários, Rio de Janeiro, in Revista dos constructores 1886

SOUZA, E.V.P. de. Reminiscências Acadêmicas. In MOURA, Carlos Eugenio Marcondes de (Org.). Vida Cotidiana em São Paulo no Século XIX. São Paulo: UNESP / Impr. Oficial do estado, 1998.

TOLEDO, Benedito Lima de. São Paulo três cidades em um século São Paulo, Editora Livraria duas cidades., 1980. 